\title{
Revisão das Espécies de Morion Latreille, 1810 das Américas (Carabidae: Harpalinae: Morionini)
}

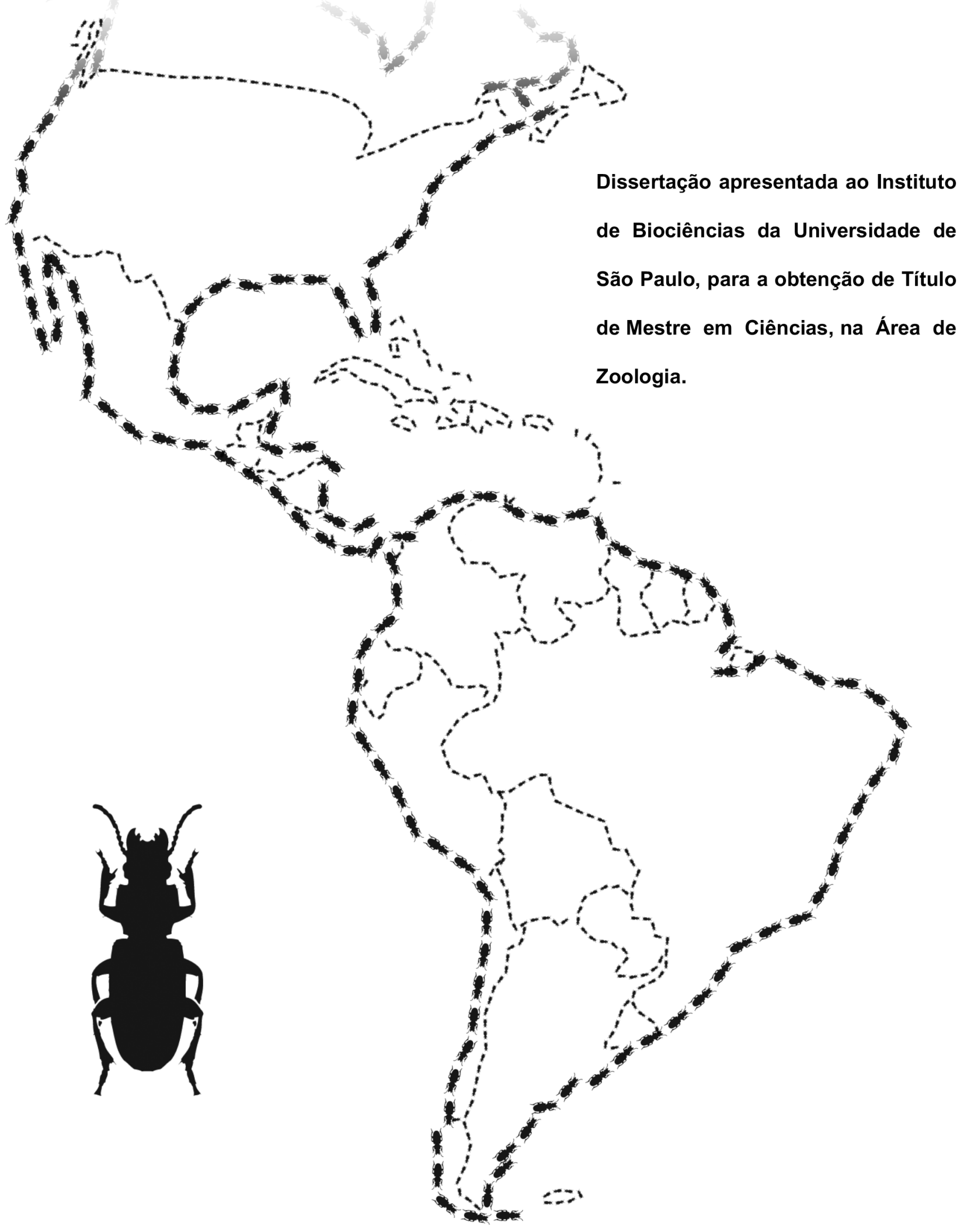




\section{Revisão das Espécies de Morion Latreille, 1810 das Américas (Carabidae: Harpalinae: Morionini).}

Dissertação apresentada ao Instituto de Biociências da Universidade de São Paulo, para a obtenção de Título de Mestre em Ciências, na Área de Zoologia.

Orientadora: Sônia Aparecida Casari

São Paulo 


\section{Ficha Catalográfica}

dos Santos, Guilherme Ide Marques

Revisão das Espécies de Morion

Latreille, 1810 das Américas (Carabidae:

Harpalinae: Morionini).

$85+x$ páginas, 65 pranchas

Dissertação (Mestrado) - Instituto de

Biociências da Universidade de São Paulo.

Departamento de Zoologia.

1. Morion 2. Américas 3. Revisão

Taxonômica I. Universidade de São Paulo.

Instituto de Biociências. Departamento de Zoologia. 


\section{Comissão Julgadora:}

Prof(a). Dr(a).

Prof(a). Dr(a).
Prof(a). Dr(a).

Prof(a). Dr(a).

Prof ${ }^{\mathrm{a}}$. Dr ${ }^{\mathrm{a}}$. Sônia Aparecida Casari

(Orientadora) 


\section{Dedicatória}

Dedico este trabalho aos meus pais, verdadeiros professores, não professores de estudos, mas professores de carinho, afeto, dedicação e apoio, em todas as horas; professores que me ensinaram a falar, levantar, andar e

seguir meu caminho.

Dedico também à pessoa carinhosa, meiga e companheira, que nos últimos anos se mostrou ser de extrema importância na minha vida, Joana, minha mulher, que sempre me inspira e me ajuda em minhas difíceis decisões, além de fazer de nossa casa um lugar maravilhoso de se viver. 
"If the future's looking dark

We're the ones who have to shine

If there's no one in control

We're the ones who draw the line

Though we live in trying times

We're the ones who have to try

Though we know that time has wings

We're the ones who have to fly..."

Neil Peart, Everyday Glory 


\section{Agradecimentos}

Começo agradecendo aos meus pais pelo apoio, compreensão e incentivo em todas as minhas conquistas. Da mesma forma agradeço meus parentes, também sempre ao meu lado. Zé, valeu pelos momentos mais engraçados da minha vida!

Agradeço muito à Joana, que há mais de seis anos não exitou em me ajudar e me confortar nos momentos em que tudo parecia não ter mais solução. Te amo muito !

Agradeço muito também à Professora Sônia Casari, minha orientadora, sempre bem humorada e disposta para me ajudar e responder minhas mais absurdas e teimosas dúvidas. Não apenas limitou-se a me ajudar em meus estudos, mas sempre me incentivou em minhas atividades fora da universidade.

Agradeço aos Professores Miguel Monné, Sérgio Ide e Lúcia Massutti de Almeida, que me receberam com toda a gentileza e hospitalidade nos institutos Museu Nacional do Rio de Janeiro, Instituto Biológio e Universidade Federal do Paraná, respectivamente, ajudando-me bastante na busca por mais exemplares do grupo aqui estudado.

Muito obrigado José Albertino Rafael, por me ajudar com as coordenadas dos exemplares do INPA, Professor Ubirajara Martins pela ajuda com as localidades dos rótulos e discussões sobre nomenclatura, Carlos Campaner pela ajuda na localização de exemplares na coleção do MZUSP e pela solução de "enigmas" contidos nas etiquetas.

Obrigado também Professor Sérgio Vanin por sempre me apoiar nos estudos dos Coleoptera e que durante meu mestrado me ajudou a entender a condição braquiptera de certos besouros e também me ajudou com dúvidas de nomenclatura. Muito obrigado Professora Cleide Costa, por sempre mostrar-se disposta a me ajudar a entender as diversas e complicadas estruturas dos besouros e que, neste trabalho, ajudou-me muito com os complexos segmentos genitais e genitália feminina do meu grupo de estudo.

Professor Pedro Gnaspini Neto, que me ajudou com problemas nomenclaturais, atendendo-me de prontidão sempre que solicitado e Professor Marcelo Duarte, que apesar de estudar um grupo menos diverso, ajudou-me a esclarecer algumas dúvidas de redação e deu-me importantes conselhos na elaboração de um trabalho científico.

Professor Nelson Papavero, que mesmo não estando no Museu de Zoologia, ajudou-me (por e-mail) em algumas dúvidas nomenclaturais.

Não posso também esquecer dos funcionários do Museu de Zoologia, que fazem do Museu um excelente local de trabalho; muito obrigado bibliotecárias do Museu de Zoologia pela ajuda na localização dos livros, tão essenciais para minha pesquisa.

Amigos do Museu de Zoologia, sem vocês a vida acadêmica seria um tédio! Valeu Peterson pelos toques e conselhos que foram muito úteis durante meu aprendizado; Fernadoso valeu pela insistência nos estudos dos louvas; Mauricioso pelos momentos hilários dentro e fora do Museu; Daniella, que mesmo pelo curto tempo que está no Museu também ajudou para deixar o clima da sala sempre divertido e Henrique, que sempre me ajudou com dúvidas relacionadas à fotografia e que "me deu uma mão" para fotografar alguns espécimens.

Por fim, sou extremamente grato ao $\mathrm{CNPq}$ pela bolsa de estudos cedida durante o desenvolvimento do presente trabalho. 


\section{ÍNDICE}

Resumo

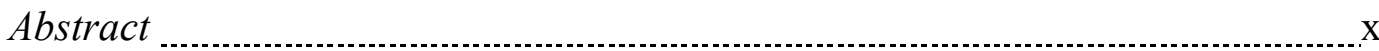

Introdução

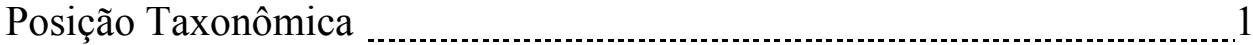

Biologia e Caracterização de Adultos e Larvas de Carabidae .................... 3

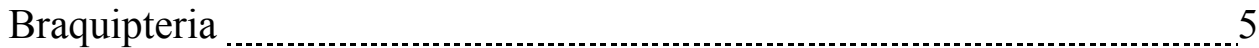

Histórico

Objetivos

$\begin{array}{ll}\text { Justificativa } & 11\end{array}$

Material e Métodos

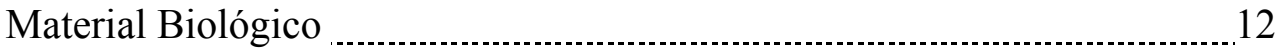

Métodos

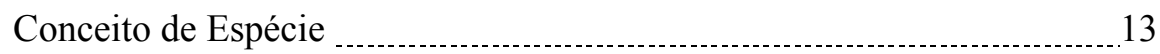

Dissecções e Ilustrações _............................................................ 13

Arte Final das Ilustrações ………................................................... 14

Etimologia e Nomenclatura ……............................................... 17

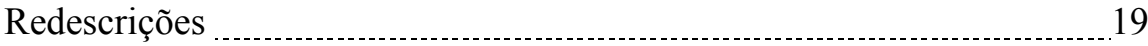

Chave Dicotômica de Identificação ............................................... 20

Elaboração da Lista do Material Examinado …….............................. 20

Construção dos Mapas de Distribuição Geográfica ………......................2 21

Resultados

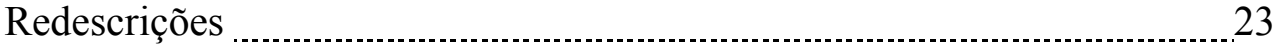

Morion Latreille, 1810

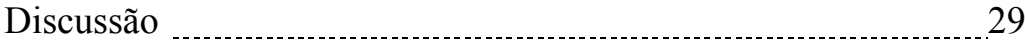

Chave Dicotômica de Identificação para as Espécies

Americanas de Morion (adultos) _......................................... 32

Morion arida Allen, 1968

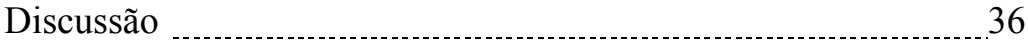


Morion boliviensis Allen, 1968 .................................................. 36

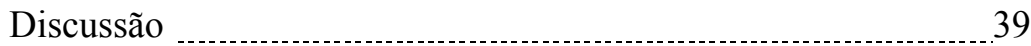

Morion brasiliensis Dejean, 1825

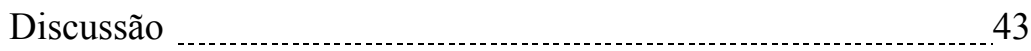

Morion cordata Chaudoir, 1837............................................... 44

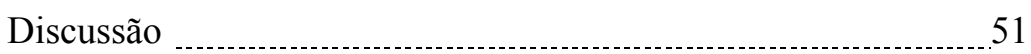

Morion costigera Darlington, 1934

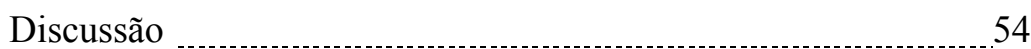

Morion cycloma Chaudoir, 1854

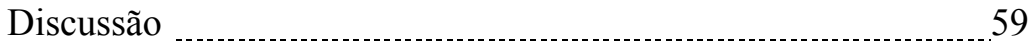

Morion lafertii Guérin, 1844

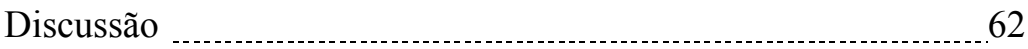

Morion monilicornis (Latreille, 1806) …….........................................63

Duscussão

Morion simplex Dejean, 1826 ........................................................ 67

Discussão _................................................................... 73

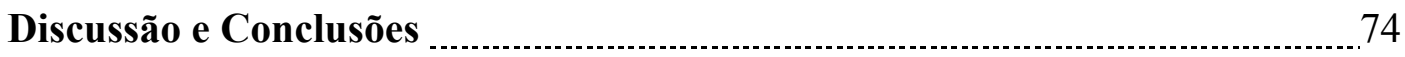

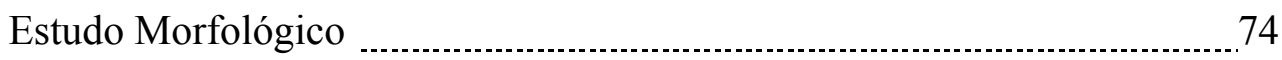

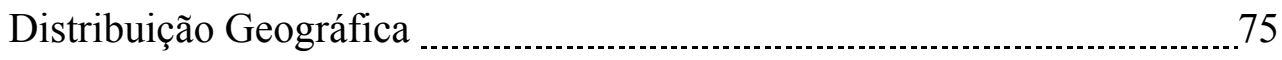

Nomenclatura

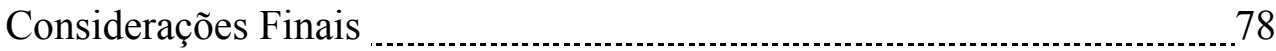

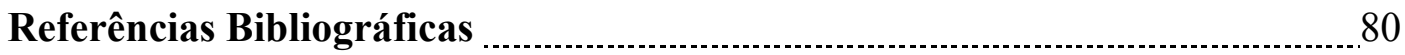




\section{Resumo}

Este trabalho trata da revisão taxonômica das espécies de Morion do Continente Americano (M. arida, M. boliviensis, M. brasiliensis, M. cordata, M. costigera, $M$. cycloma, M. lafertii, M. monilicornis e M. simplex), sendo que apenas uma não ocorre na região Neotropical (M. monilicornis).

Foi realizado um estudo morfológico detalhado de todas as espécies, visando encontrar novos caracteres diagnósticos para testar a hipótese taxonômica vigente e para facilitar a identificação das espécies. Não foram identificadas espécies novas e as nove espécies mostraram-se válidas. A análise de novas estruturas, além de revelar características antes não estudadas (como braquipteria em M. brasiliensis) deu mais robustez à hipótese existente.

Também foram confeccionados mapas de distribuição geográfica de todas as espécies, o que revelou que algumas apresentam distribuição bastante restrita (principalmente as espécies braquípteras), enquanto outras têm uma distribuição bastante ampla.

Uma chave dicotômica para a identificação das espécies foi preparada, visando facilitar a identificação das mesmas. 


\section{Abstract}

This study is a taxonomic revision of the New World Morion, which has nine valid species (M. arida, M. boliviensis, M. brasiliensis, M. cordata, M. costigera, $M$. cycloma, M. lafertii, M. monilicornis and M. simplex), of which, only one of them is not recorded in the Neotropical region (M. monilicornis).

A detailed morphological study was done aiming for finding out new diagnostic characteristics in order to test the current taxonomic hypothesis and to make specific identification easier. These nine species were analyzed and remained valid; no new one was found. The analysis of new structures made it possible to find some characters never studied before (e.g., M. brasiliensis brachyptery) and strengthened the previous hypothesis.

The maps representing the geographic distribution of all species revealed that some of them have a limited area of occurrence (mainly the flightless species), although others are widespread.

A dichotomic identification key was also done to facilitate species identification. 


\section{INTRODUÇÃo}

\section{Posição Taxonômica}

A ordem Coleoptera está dividida em 4 subordens: Archostemata, Myxophaga, Adephaga e Polyphaga.

A subordem Adephaga está subdividida em dois grupos distintos: Geadephaga e Hydradephaga. Os Geadephaga são representados pelos Adephaga terrestres (Carabidae e Trachypachidae) e os Hydradephaga, pelos aquáticos (Martinez, 2005).

A família Carabidae é a mais diversa dentre os Adephaga e está formada por 1.869 gêneros (Lorenz 1998 apud Erwin, 2002) incluídos em nove subfamílias (Reichardt, 1977) e aproximadamente 100 tribos. O número de espécies descritas está estimado em 33.000 (Lorenz 1998 apud Erwin, 2002).

A família é caracterizada principalmente por apresentar tamanho muito variado $(1,0-70,0 \mathrm{~mm})$, corpo relativamente achatado dorso-ventralmente e levemente convexo. As cores são variadas, mas o preto e marrom-escuro são as mais comuns (Reichardt, 1977). Apresentam mandíbulas e palpos proeminentes, e metasterno encurtado com uma distinta sutura transversa. Geralmente apresentam élitros estriados e pernas finas (Lawrence, 1994).

A subfamília Harpalinae (sensu Erwin, 1885) é a mais diversa dos Carabidae, contendo mais de 19.000 espécies (Lorenz 1998). Devido a esta grande diversidade, nota-se que esse grupo é formado por indivíduos com muitas diferenças, não só morfológicas, mas também comportamentais (Ober, 2002). Alguns autores não consideram Harpalinae como subfamília, por exemplo Reichardt (1977), que considera na subfamília Carabinae, as tribos tradicionalmente conhecidas de Harpalinae, incluindo, deste modo, a tribo Morionini. Para resolver este problema, alguns autores estão começando a utilizar dados moleculares para verificar a possibilidade de Harpalinae ser um grupo natural. Ober $(2002,2003)$ fez estudos filogenéticos utilizando dados moleculares. O cladograma para o qual foram utilizados todos os dados moleculares combinados mostra que Harpalinae forma um clado, porém as relações dos grupos pertencentes a este clado são incertas. Tais análises mostram também que 
Morionini pertence a essa subfamília. Martinez (2005) também considera Morionini como tribo de Harpalinae.

A tribo Morionini é composta por nove gêneros dos trópicos do Velho e Novo Mundo, sendo eles: Stereostoma Murray, 1857, Morionidius Chaudoir, 1880, Buderes Murray, 1857, Hyperectenus Alluaud 1935, Moriosomus Motschulsky 1864, Hyperion Laporte de Castelnau, 1834, Morion Latreille, 1810, Megamorio Chaudoir, 1880 e Platynodes Westwood (Will, 2004).

Vários autores consideram Morionini como uma subtribo de Pterostichini, mas atualmente é considerada como tribo (Reichardt, 1977, Martinez, 2005). De acordo com dados da literatura, adultos e larvas de Morionini vivem em troncos caídos e os adultos têm asas bastante desenvolvidas (Reichardt, 1977), com exceção de Morion costigera Darlington, 1934 que tem asas reduzidas (Darlington, 1941). Os adultos caçam durante a noite e podem ser transportados por humanos através da madeira (Darlington, 1970), sendo, deste modo, facilmente dispersados pelo planeta.

Os membros da tribo Morionini compartilham as seguintes características, com as exceções assinaladas: antenas moniliformes (submoniliformes em Hyperion Laporte), olhos proeminentes (exceto em Hyperectenus Alluad), plica elitral não visível externamente, ápice da protíbia com um espinho ápico-lateral (exceto em Morionidius), e um processo dentiforme frontal projetando-se acima do ponto de inserção da antena (Will, 2004).

Em sua revisão da tribo, Will (2004) observou que apenas a margem ocular profundamente emarginada, a têmpora relativamente pequena, moderadamente proeminente e antenômeros moniliformes se comportam como sinapomorfias do grupo.

O gênero Morion apresenta distribuição mundial e está formado por 41 espécies (Will, 2004); nove são registradas para as Américas (Allen, 1968) e estão enumeradas a seguir:

1. M. arida Allen, 1968

M. aridus Allen, 1968

2. M. boliviensis Allen, 1968

3. M. brasiliensis Dejean, 1825

M. brasiliense; Allen, 1969

4. M. cordata Chaudoir, 1837

M. cordatus Chaudoir, 1837 
M. aequatorium Reiche, 1842

M. aequatorius; Schenkling, 1925

Morion elongatus Chevrolat, olim

5. M. costigera Darilington, 1934

M. costigerus Darlington, 1934

6. M. cycloma Chaudoir, 1854

M. cyclomus Chaudoir, 1854

7. M. lafertii Guérin, 1844

M. lafertei; Chaudoir, 1880

M. spiniger Chaudoir, 1854

8. Morion monilicornis (Latreille, 1806)

Harpalus monilicornis Latreille, 1806

Scarites georgiae Palisot, 1821

Morion georgiae (Palisot, 1821)

Morion cayennensis Dejean, 1821

9. M. simplex Dejean 1826

M. bifemuratus Dejean, 1831

M. bifemuratum; Allen, 1968

\section{_Biologia e Caracterização de Adultos e Larvas de \\ Carabidae}

Os carabídeos são encontrados numa ampla variedade de ambientes, e como são besouros de hábito predador, têm um papel muito importante no controle biológico. Porém apenas algumas espécies são usadas pelo homem para este fim. Algumas espécies são herbívoras (Harpalini) e raras detritívoras (Callistini) (Marinoni et al, 2001).

Uma particularidade da família está na presença de duas glândulas no interior do abdômen que produzem fortes odores e secretam substâncias químicas usados como defesa (Erwin, 2002). Em alguns grupos de carabídeos, chamados de "besouros bombardeiros", como por exemplo os Brachinini, essa secreção é expelida de maneira 
explosiva chegando a temperatura de $100^{\circ} \mathrm{C}$, mostrando-se muito eficiente até mesmo contra sapos (Dean, 1980). Este sistema de defesa é único entre os Coleoptera (Erwin, 2002).

Muitas espécies põem ovos individualmente em pequenos buracos no substrato; outros envolvem seus ovos individualmente com lama, os quais são soltos no substrato ou fixados em troncos ou folhas. Algumas espécies de Pterostichini demonstram ter cuidado parental; as fêmeas põem os ovos em uma câmara feita no solo ou dentro de troncos podres e permanece em cima ou perto deles até que a larva ecloda e fique mais rígida. As fêmeas, aparentemente são mais eficientes na defesa de seus ovos contra ataques de fungos do que contra predadores (Löser 1970 apud Bousquet 1991).

A maioria dos Carabidae apresenta três ínstares larvais; poucas espécies têm dois (algumas espécies de Amara, algumas espécies de Harpalus e Thermophilum sexmaculatum Fabricius), quatro (Eurycoleus macularis Chevrolat) ou 5 ínstares (Brachinus). Embora em várias espécies o desenvolvimento dos estágios imaturos seja rápido, em alguns grupos de Carabidae, como Scaphinotus, Nebria, Patrobus, Calathus, Synuchus e alguns Pterostichini, as larvas fazem diapausa térmica. Neste caso a pupa fica em uma câmara a poucos centímetros abaixo do substrato (Bousquet 1991).

As larvas de Carabidae são predadoras e apresentam digestão extra-oral. Membros de Lebiini e Brachininae possuem, em geral, larvas ectoparasitas (Costa et al, 1988).

As larvas de Carabidae são terrestres e se caracterizam por serem alongadas, normalmente com margens laterais paralelas, ocasionalmente fusiformes; variando de muito convexas a deprimidas. A cabeça, o pronoto e a extremidade abdominal são bastante esclerotizadas. Essas larvas têm a cabeça em geral levemente convexa com seis ou menos estemas de cada lado; os estemas às vezes estão ausentes. A sutura coronal pode estar ausente ou presente. As antenas possuem 3 ou 5 antenômeros. Possuem labro e clípeo fundidos com a fronte, mandíbulas sem canal suctório e com retináculo, raramente com prosteca hialina e palpos labiais bastante desenvolvidos com dois (normalmente) ou quatro palpômeros. Suturas gulares confluentes. Suas pernas possuem seis segmentos (coxa, trocânter, fêmur, tíbia, tarso e pré-tarso), porém, ocasionalmente as pernas podem ser reduzidas. Nono tergito quase sempre bem desenvolvido e geralmente com urogonfos fixos ou articulados. Oitavo e nono segmentos raramente formando disco glandular; décimo segmento, em geral, tubular e terminal. Todos os 
espiráculos são funcionais e posicionam-se sublateralmente nos segmentos abdominais (Costa et al, 1988; Bousquet, 1991). Comumente as larvas de Carabidae são confundidas com larvas de Staphylinidae, Silphidae e Histeridae, porém as pernas das larvas de Carabidae possuem garras tarsais ao contrário das outras famílias (Bousquet, 1991).

\section{Braquipteria}

A maioria dos Carabidae tem asas membranosas bastante desenvolvidas, o que possibilita que o inseto voe e tenha assim uma ampla dispersão e, em certos casos, mostra-se essencial na sobrevivência do inseto em ambientes estressantes. Há muitos exemplos em que são mostradas algumas das importâncias do vôo para os carabídeos, como, por exemplo, escapar de alagamentos próximos a rios e lagos e permanecerem sobre a vegetação nas espécies arborícolas (Darlington 1943).

Há espécies em que ambos os sexos apresentam braquipteria e espécies em que apenas as fêmeas apresentam tal característica. Em outras ainda, alguns indivíduos apresentam e outros não (polimorfismo), mas provavelmente nenhum Carabidae possui apteria, ou seja, ausência total de asas. Mesmo quando bastante reduzidas e modificadas, foi possível identificar algum vestígio de asas membranosas em todas as espécies examinadas por Darlington (1936). Em alguns casos os élitros podem apresentar-se fundidos.

Em carabídeos braquípteros, outros caracteres secundários mostram-se freqüentemente presentes, como o metatórax, que é normalmente amplo e forte para suportar os músculos do vôo e permitir suas inserções, muitas vezes torna-se mais curto e frágil depois da degeneração dos músculos. O metanoto é especialmente afetado, pois os escleritos que são bastante esclerotizados formam apenas uma barra estreita e transversa atrás do escutelo. O metaepisterno é também mais curto nas espécies com asas membranosas vestigiais. Da mesma forma que o metatórax se torna diminuído, os úmeros elitrais, que são encaixados nesse, tornam-se correspondentemente mais estreitos, arredondados e, em alguns casos, suprimidos. A perda do olho pode acompanhar a perda da capacidade do vôo em algumas espécies, porém uma ligação 
direta entre a redução das asas e a redução dos olhos raramente acontece entre os Carabidae (Darlington 1936). Provavelmente essa ligação deve se dar devido à necessidade da visão durante o vôo, pois a ausência da visão é um caráter mais crítico para um animal que voa do que para um não voador. Deste modo, linhagens com asas reduzidas têm maior chance de sobrevivência sem visão do que um indivíduo que voa.

Normalmente as asas membranosas dos carabídeos são simétricas, mas há casos de assimetria. Essa assimetria ocorre de diferentes formas, especialmente na porção apical da asa reduzida. Platynus retractus (LeConte, 1848) de Tyngsboro tem a asa membranosa direita totalmente desenvolvida e dobrada de maneira complexa, mas a asa esquerda é bastante reduzida, com cerca de $3 / 5$ do comprimento do élitro, não dobrada, com pterostigma quase apical e venação distinta (Darlington 1936).

Diversos trabalhos de biogeografia foram feitos usando-se indivíduos braquípteros. Entre os principais pesquisadores estão Darlington e Lindroth. O motivo de se usar animais incapazes de voar em trabalhos de biogeografia é porque se acredita que esta característica é selecionada em ambientes semelhantes ou que passaram por transformações equivalentes.

Sabe-se que a maioria dos carabídeos braquípteros é encontrada em montanhas e ilhas. Em "Origem das Espécies", Darwin acreditava que os indivíduos que viviam em ilhas e voavam tinham grande chance de serem carregados pelo vento e morrerem no mar; já os que não voavam seriam, deste modo, selecionados. Há muitos estudos mostrando o papel das montanhas como "refúgio" que seleciona animais não voadores (por exemplo Dalington 1943). Brandmayr et al. (1983) sugerem que a estabilidade do local é o fator principal na seleção de carabídeos braquípteros na região Adriártica noroeste; já Erwin (1979) discutiu o efeito de ambientes fragmentados no desenvolvimento de braquipteria na fauna de planície.

Para explicar as possíveis causas para a seleção de indivíduos braquípteros em montanhas, Darlington (1943, 1971) apontou a seguinte particularidade destes ambientes: áreas de microclima excepcionalmente uniforme (temperatura amena e com freqüente precipitação e ausência de enchentes) funcionam como uma espécie de tampão contra mudanças climáticas drásticas, mas, se isto ocorrer, os organismos precisam apenas percorrer curtas distâncias para cima ou para baixo para achar a condição ideal. Já os organismos de planície precisam mover-se centenas ou milhares de quilômetros para norte ou sul para achar tal condição. Para Darlington, o efeito 
seletivo de ilhas onde vivem indivíduos braquípteros está muito mais relacionado a suas montanhas do que ao fato de serem ilhas, já que não é muito comum encontrar tais indivíduos em ilhas baixas e planas, mas esperado em ilhas montanhosas.

Darlington $(1936,1943)$ também explorou uma relação entre geografia e braquipteria e observou que é muito mais comum carabídeos braquípteros em regiões temperadas do que na região tropical. Aproximadamente $24 \%$ das espécies de Carabidae do leste da América do Norte tem dimorfismo na asa ou tem apenas indivíduos braquípteros e 45\% da fauna australiana é braquíptera (Darlington 1961). Por outro lado, apenas de 12 a $15 \%$ da fauna sul-americana é braquíptera ou dimórfica. Para Darlington (1943) isto se deve à grande competição com formigas na América do Sul que contribui para a pequena quantidade relativa de carabídeos geófilos, e desta forma, de braquípteros. Esses dados foram observados, mas deve-se também levar em consideração a grande dificuldade de se coletar a fauna de solo em florestas tropicais, já que há muito mais matéria orgânica sobre o solo.

\section{Histórico}

Latreille (1810) criou o gênero Morion para incluir Harpalus monilicornis Latreille, 1806. Esse trabalho apresenta uma breve descrição da espécie-tipo, caracterizada pelas antenas moniliformes, com o segundo antenômero mais curto que o terceiro.

Lamarck (1817) criou Morio para, erroneamente, substituir Morion Latreille, 1810, mesmo sendo o primeiro nome pré-ocupado. Morio já tinha sido usado por Montfort (1810) para se referir a um grupo de Mollusca.

Dejean, em seus trabalhos, sempre se referia a Morion como Morio, seguindo Lamarck (l.c.). Em 1825, Dejean sinonimizou Scarites georgiae Palisot, 1821 e Morio cayennensis Dejean com Morio monilicornis (Latreille, 1806) e descreveu $M$. brasiliensis e M. orientalis. Nesse trabalho, ao descrever M. brasiliensis, Dejean cita a referência de seu catálogo de 1821, onde o autor apenas citou o nome da espécie, para somente quatro anos depois descrevê-la. Isso foi comprovado no Index Animalium (Sherborn, 1922) onde consta "[n.n.]” (nomen nudum) após a referência do catálogo de 
Dejean,1821, tendo logo em seguida a citação do trabalho de 1825 onde de fato Dejean descreve a espécie.

Dejean (1826) descreveu brevemente Morio simplex e o considerou uma espécie bastante parecida com M. monilicornis, mas maior. Cinco anos depois (1831), descreveu M. bifemuratus, baseado em um exemplar anteriormente listado, mas não descrito por Klug, e, ao mesmo tempo sinonimizou essa espécie recém-descrita com $M$. simplex Dejean, 1826. Também descreveu M. pygmeus.

Chaudoir, em 1837 descreveu a espécie M. cordatus.

Chevrolat (1841) redescreveu Morion cordatus Chaudoir, 1837 e citou M. elongatus Chevrolat, olim. como sinônimo. O nome genérico foi corrigido e Morio Lamarck, 1817 foi sinonimizado com Morion Latreille, 1810.

Guérin (1844a) não considerou a sinonimização de Chevrolat (l.c.) e descreveu Morio lafertii, comparando-o com M. monilicornis (Latreille, 1806) e M. brasiliensis Dejean, 1826. Trabalhos mais recentes tratam erroneamente a espécie descrita como Morion lafertei, sendo a grafia original do epíteto "lafertii". No mesmo ano (1844b), em sua obra de iconografia do Reino Animal, Guérin citou M. simplex e incluiu um desenho de um espécime.

Lacordaire (1854) não considerou a mudança de Chevrolat (1841) e criou o grupo "Morionides", no qual incluiu Morio juntamente com dez outros gêneros. Neste mesmo ano, Chaudoir descreveu M. cyclomus.

Vinte e seis anos mais tarde (1880), Chaudoir, em seu trabalho "Essai Monographique sur les Morionides" tratou dos gêneros do grupo "Morionides" e, não considerando a mudança de Chevrolat (1841), apresenta uma chave para as espécies de Morio, separadas de acordo com a quantidade de cerdas presentes no protórax: com muitas cerdas ou com apenas duas cerdas laterais. Considerou M. monilicornis, M. cordatus e M. aequatorius sinônimos de M. georgiae Palisot, 1821.

Horn (1881) apresentou uma chave para as subfamílias e tribos de Carabidae, e redescreveu a tribo Morionini.

Schenkling (1925) catalogou as tribos de Carabidae e Morion foi incluído na "subtrib. Morioni" (Morionini é sinônimo), que por sua vez pertence à tribo Pterostichini. São listados 10 gêneros em Morioni, sendo que Morion conta com 35 espécies válidas, sendo cinco delas neotropicais: $M$. brasiliensis Dejean, 1825, M. cyclomus Chaudoir, 1854, M. georgiae Palisot, 1821 (sendo M. monilicornis (Latreille, 
1806), M. cordatus Chaudoir, 1837 e M. aequatorius Reiche, 1842, sinônimos), $M$. lafertei Guérin, 1844 (sendo M. spiniger Chaudoir, 1854, sinônimo) e M. simplex Dejean, 1826 (sendo M. bifemuratus Dejean, 1831, sinônimo).

Darlington (1934) descreveu Morion costigerus e manteve M. monilicornis como sinônimo de $M$. georgiae.

Neave (1940) publicou uma lista de nomes de gêneros e subgêneros em Zoologia, listando dois gêneros Morio, sendo que um (Morio Montfort, 1810), válido e se trata de um grupo de Mollusca e outro (Morio Lamarck, 1817), sinônimo de Morion Latreille, 1810.

Blackwelder (1944) catalogou onze espécies nominais do Novo Mundo, sendo seis espécies válidas: Morion brasiliense, M. costigerum, M. cyclomus, M. georgiae (sendo M. monilicorne, M. aequatorium e M. cordatum, sinônimos), M. lafertei (sendo M. spinger, sinônimo) e M. simplex [sendo M. bifemuratum sinônimo].

Em 1953, Emden comparou as espécies M. orientalis e M. georgiae e citou as diferenças entre os caracteres larvais dessas espécies.

Allen (1968), em sua sinopse da tribo Morionini do Hemisfério Oeste, considerou 7 espécies válidas para Morion e as redescreveu. Também redescreveu Moriosomus, gênero até então monotípico. Além disso, duas espécies novas foram descritas: Morion boliviensis e Morion aridus totalizando, portanto, 9 espécies válidas. Allen não concordou com Blackwelder (1945) corrigindo dois pontos: considerou $M$. monilicornis (Latreille, 1806) como espécie válida e M. georgiae Palisot, 1821 como seu sinônimo. Além disso, M. cordatus Chaudoir, 1837 listado como uma variação de M. georgiae foi considerada uma espécie válida e M. aequatorius Reiche, 1842, também listado como variação de $M$. georgiae foi considerada sinônimo de M. cordatus.

Darlington (1970) se referiu a Morion como pertencente à tribo Pterostichini. Escreveu um pouco sobre a biologia do gênero.

Thompson (1977) redescreveu e detalhou os três estágios larvais de M. cordatus, até esse momento a única espécie da tribo com larva conhecida.

Reichardt (1977), em sua sinopse dos gêneros de Carabidae Neotropicais, concordou com Allen (1968) e considerou o gênero Morion com distribuição mundial, sendo sete espécies neotropicais, quatro delas registradas no Brasil. Também incluiu uma pequena chave para diferenciar Morion de Moriosomus Motschulsky, 1864. 
Jorge-Silva (1979), em sua tese para o título de Doutor em Ciências na área de Zoologia, não publicada, fez um estudo comparativo das peças bucais de gêneros de carabídeos Neotropicais, no qual descreveu as peças bucais de Morion simplex.

Jorge-Silva \& Costa (1983) descreveram a larva e pupa de M. brasiliense e $M$. cordatus. As autoras discutiram que a larva de M. orientalis difere em muitos aspectos das espécies do Novo Mundo (M. brasiliense, M. cordatus e M. monilicornis) e portanto possivelmente pertence a um grupo diferente dessas três espécies neotropicais. Andrewes (1946) já havia comentado que o adulto de tal espécie do Velho Mundo apresenta características que o diferem das outras espécies de Morion.

Davidson (1990) discutiu brevemente as espécies da tribo Morionini que ocorrem no Equador: Morion cordatus, M. simplex e Moriosomus seticollis Straneo 1985 .

Em 1993 Bousquet e LaRochelle publicaram um catálogo dos Geadephaga norte americanos e mexicanos, listando apenas $M$. aridus e M. monilicornis.

Ober (2002) apresentou a filogenia da subfamília Harpalinae baseado em seqüência de dados moleculares. Neste trabalho Morion aparece como grupo monofilético e grupo irmão de Moriosomus. Em 2003, o mesmo autor fez um trabalho relacionando hábitos de arborismo com adaptações morfológicas, e mais uma vez, Morion aparece como grupo monofilético e grupo irmão de Moriosomus.

Em 2004, Will fez uma revisão e análise cladística da tribo Morionini. Neste trabalho ele analisou apenas algumas espécies de Morion: . aridus, M. cordatus, $M$. monilicornis, M. simplex e algumas espécimes não identificados de diversos países, incluindo México e República Dominicana. Em sua chave de identificação dividiu o gênero em dois grupos: Morion (s.str.) Latreille, com o protarsômero sem dentículo médio-apical e Morion (Neomorion) Jeannel, com dentículo médio-apical no primeiro protarsômero; esta divisão já tinha sido proposta por outros autores (Jeannel 1948 e Straneo 1952). Apresentou também um cladograma, porém o táxon Morion não apresenta autapomorfias.

Até o momento a tribo Morionini é composta por 9 gêneros e 92 espécies, sendo Morion o gênero mais diverso com 9 espécies no Novo Mundo e outras 32 espécies em outras partes do planeta (Will, 2004). 


\section{Objetivos}

Os principais objetivos desse projeto foram:

1. Estudo morfológico das espécies do gênero Morion das Américas;

2. Análise de estruturas não examinadas em trabalhos anteriores;

3. Revisão taxonômica das espécies do Novo Mundo;

4. Elaboração de uma chave de identificação;

5. Levantamento da distribuição geográfica das espécies do Novo Mundo.

\section{Justificativa}

O único trabalho no qual todas as espécies de Morion das Américas foram estudadas foi o de Allen (1968). Porém nota-se que muitas estruturas hoje usadas na taxonomia da família não foram estudadas e há poucas ilustrações de estruturas importantes para complementar as descrições e redescrições das espécies. Além disso, novas coletas foram feitas, possibilitando o aumento da distribuição geográfica do grupo.

Deste modo, uma nova revisão das espécies desse grupo complementa de modo significativo o estudo feito anteriormente. 


\section{MATerial e Métodos}

\section{Material Biológico}

Foram examinados 634 exemplares pertencentes às instituições listadas abaixo, com o nome do curador entre parênteses. As abreviaturas seguem Arnett et al. (1993, 2006).

(AMNH) American Museum of Natural History, Nova Iorque, Nova Iorque, Estados Unidos (Dr. Lee Herman);

(CLEV) Cleveland Museum of Natural History, Cleveland, Ohio, Estados Unidos. (Dr. Tom Pucci);

(DCMP) Universidade Federal do Paraná, Curitiba, Paraná, Brazil (Dra. Lúcia Massutti de Almeida)

(EMEC) Essig Museum of Entomology University of California, Berkeley, Califórnia, Estados Unidos (Dr. Kippling Will);

(FMNH) Field Museum of Natural History, Chicago, Illinois, Estados Unidos (Dr. Jim Boone);

(IBSP) Instituto Biológico, São Paulo, Brasil (Dr. Sérgio Ide);

(INPA) Coleção Sistemática da Entomologia, Instituto Nacional de Pesquisas da Amazônia, Manaus, Amazonas, Brasil (Dr. Augusto Henriques);

(MCNZ) Museu de Ciências Naturais da Fundação Zoo-Botânica do Rio Grande do Sul, Porto Alegre, Rio Grande do Sul, Brasil (Dra. Maria Helena M. Galileo);

(MNRJ) Museu Nacional, Universidade do Rio Janeiro, São Cristovão, Rio de Janeiro, Brasil (Dr. Miguel A. Monné Barrios);

(MPEG) Museu Paraense Emilio Goeldi, Belém, Pará, Brasil (Dr. Orlando Tobias Silvério);

(MZSP) Museu de Zoologia da Universidade de São Paulo, São Paulo, Brasil (Dra. Sônia A. Casari).

Infelizmente nenhuma instituição enviou holótipos, pois alegaram não haver segurança no envio de material para o Brasil. As instituições que enviaram material tipo foram: American Museum of Natural History, um parátipo de $M$. arida e o Field 
Museum, 2 parátipos de $M$. boliviensis. Além disso, foi examinado o parátipo de $M$. arida depositado no Museu de Zoologia. Também foram examinadas fotografias on-line do holótipo de M. costigera Darlington, 1934 e M. arida do Museum of Comparative Zoology (Universidade de Harvard). Para as espécies em que não foi possível examinar o material-tipo, foram estudados exemplares identificados por Hans Reichardt, muitos deles comparados com tipos.

\section{Métodos}

\section{CONCEITO DE ESPÉCIE}

É de extrema importância para um trabalho de sistemática definir qual o conceito de espécie utilizado, visto a grande quantidade de significados que esta terminologia pode apresentar.

No presente trabalho foi utilizado o conceito filogenético de espécie proposto por Nixon e Wheeler (1990). Neste conceito uma espécie é definida por ser "a menor agregação de populações (sexual) ou linhagens (assexual) diagnosticada por uma combinação única de estados de caracteres em indivíduos comparáveis (semaforontes)".

Este foi o conceito escolhido por melhor adequar-se ao método utilizado para o desenvolvimento do presente trabalho.

\section{DISSECCÕES E ILUSTRAÇÕES}

Para cada espécie estudada, um ou mais exemplares foram dissecados (com exceção dos tipos), ilustrados e a espécie redescrita. Foram ilustrados: antena, cabeça, peças bucais (labro, mandíbula, maxila e lábio), pronoto, perna, asa membranosa, élitros e segmentos genitais e genitália do macho e da fêmea. Também foi apresentado uma fotografia de corpo inteiro em vista dorsal para cada espécie. As ilustrações foram realizadas com auxílio de câmara clara acoplada ao microscópio estereoscópico. Os desenhos foram feitos a lápis, escaneados e trabalhados digitalmente usando diferentes programas de computador. Por serem os exemplares escuros, houve dificuldade na 
localização de cerdas em determinadas áreas onde as pontuações eram muito fracas ou não visíveis; nesses casos, olhar o exemplar em um ângulo perpendicular à orientação das cerdas, muitas vezes resolveu o problema.

Para as dissecções, cada exemplar foi fervido durante 5 a 10 minutos em uma solução aquosa com detergente líquido para hidratação e amolecimento dos tecidos. Depois da fervura, as articulações ficaram mais moles e foi possível retirar as peças bucais, asa membranosa e abdômen. Para a dissecção das genitálias, o abdômem, após ser retirado, foi fervido em água com hidróxido de sódio numa concentração de duas pastilhas para $50 \mathrm{ml}$ de água. O tempo de fervura variou de acordo com o tamanho e rigidez do exemplar. As dissecções foram feitas em água sob microscópio estereoscópico, com auxílio de estiletes, pinças e tesoura de ponta fina. Depois de dissecadas, as peças bucais e genitálias foram lavadas em água corrente, passadas em álcool 70\%, 80\% e 96\% e depois transferidas para uma lâmina com glicerina, onde foram mantidas de forma adequada para serem desenhadas. A asa foi retirada pela base com auxílio de uma pinça de ponta fina, colocada em uma lâmina com uma gota de álcool $70 \%$ e então esticada. Depois, foi colocada outra lâmina por cima da asa para esta secar em tal posição para, posteriormente, ser desenhada. Após o desenho, a asa foi colada pela base em um pedaço de cartolina branca e esta alfinetada junto ao exemplar.

Quando o trabalho de ilustração foi terminado, o abdome foi colado de volta no corpo do animal e as peças bucais e genitália foram colocadas em um tubinho de plástico com tampa de borracha contendo glicerina (um tubinho para as peças bucais e outro para a genitália) e alfinetados junto ao exemplar. Finalmente os indivíduos foram arrumados e organizados para serem devolvidos à coleção.

Também foram feitos desenhos esquemáticos de algumas estruturas, com legendas, para facilitar a localização das partes (pranchas 05, 09, 20, 37, 41, 43 e 47).

\section{ARTE FINAL DAS ILUSTRACÕES}

Com o objetivo de escolher o melhor método para ser utilizado nas ilustrações de uma futura publicação, diferentes programas de computador foram testados.

Para digitalizar as figuras, foram utilizados dois métodos. 
O método mais simples (método 1 - fig. 02b, 04a, 04b, 04c, 04d, 07d entre outras), foi escanear a figura feita a lápis (normalmente a 300 ou 600 dpi, dependendo do tamanho original da figura), abri-la com o programa Photoshop CS2 e acentuar o brilho e o contraste a fim de eliminar as manchas mais claras do papel e reforçar os traços escuros. Numa etapa posterior, manchas mais escuras e outras imperfeições foram removidas com as ferramentas carimbo e borracha.

Um outro método (método 2 - fig. 02c, 02d, 11d, 22d, 25c entre outras) similar testado foi refazer as figuras em papel vegetal usando tinta nanquim preta antes de escanear as figuras. Para desenhar, o papel vegetal foi posto sobre o desenho a lápis, o contorno foi feito seguindo o traço original e, em alguns casos, foram feitos sombreamentos utilizando técnica de pontilismo. Após escanear as figuras do papel vegetal, foi seguido o método anterior.

Foram utilizados também três outros métodos, nos quais o desenho foi refeito digitalmente após o escaneamento.

O primeiro método (método 3 - fig. 07c, 22c, 27a, 27b, 27c, 27d, entre outras) consistiu em abrir a figura digitalizada com o programa Photoshop, criar uma nova camada e desenhar por cima das linhas do desenho original (com auxílio de uma mesa digitalizadora) usando um pincel preto. Após o término do desenho, a figura original foi apagada, restando somente os traços novos. Esta figura foi "achatada" (flatten image) e então gravada em formato JPG ou BMP.

O segundo método utilizado (método 4 - fig. 02a, 19a, 19d, 22a, 40c entre outras) foi, após concluir o método 3, abrir essa nova figura com o programa Adobe Illustrator CS2, selecioná-la e vetorizá-la clicando no botão "live trace". Após a vetorização, o arquivo foi exportado em formato JPG ou BMP. Um cuidado a ser tomado ao vetorizar textos é que as letras podem ficar um pouco deformadas (prancha 09). Quando uma ilustração ou esquema apresentava algum tipo de texto, este foi escrito somente após vetorizar o desenho.

O terceiro método (método 5 - prancha 37) constituiu em abrir a figura recém digitalizada com o programa Corel Draw 12 e desenhar por cima do desenho original usando traços vetoriais. Ao concluir o desenho, a figura original foi apagada e a figura restante (somente os traços vetoriais) foi exportada em formato PSD. A etapa seguinte foi abrí-la no programa Photoshop e gravá-la em formato JPG. Esta etapa de primeiro 
salvar em PSD, para depois salvar em JPG foi necessária, pois ao tentar exportar diretamente para JPG a qualidade resultante mostrou-se pior.

Quando foi necessário preencher partes das estruturas ilustradas, isto foi feito com o programa Photoshop. O preenchimento foi feito em uma nova camada no modo "Multiply" (prancha 37, fig. 38c, 38f).

\section{Discussão}

Todos os métodos utilizados mostraram-se vantajosos em certos aspectos e desvantajosos em outros.

O método 1 (escanear o desenho feito à lápis e trabalhar o brilho e o contraste) mostrou-se o mais rápido, porém a qualidade da imagem resultante não foi consideravelmente melhorada. Este método mostra-se bom quando a arte final é feita antes da digitalização, porém não tão eficiente ao tentar deixar boa uma figura inicialmente sem nenhum acabamento.

O método 2 mostrou-se bastante eficiente em relação ao reforço dos traços, porém o processo de passar nanquim no papel vegetal é demorado e qualquer erro tem que ser apagado com estilete (colocando em risco o papel) ou posteriormente no Photoshop (após a digitalização). Outro ponto negativo é que os traços à nanquim, não ficam preto por igual e o papel vegetal freqüentemente apresenta pequenas manchas.

O método 3 revelou-se muito bom pelas seguintes razões: reforça de maneira muito eficiente os traços; todos os pontos do traço são da mesma cor; a borda dos traços não apresenta imperfeições e qualquer erro é facilmente corrigido com alguma ferramenta ou simplesmente voltando-se uma etapa. O lado negativo se refere ao tempo necessário para desenhar digitalmente e ao fato de o usuário precisar de certa habilidade no manuseio do mouse ou da mesa digitalizadora.

O método 4 mostrou-se bastante eficiente no acabamento final, pois, ao vetorizar a figura, esta fica com os traços e curvas mais suaves, além do processo de vetorização demorar apenas alguns segundos. A principal vantagem do uso de vetores consiste em que a imagem pode ser aumentada ou diminuída sem que haja "pixelização", ou seja, mantém a mesma qualidade da imagem original. O lado (possivelmente) negativo é que ao vetorizar a figura, esta perde um pouco das características dos traços do autor, podendo parecer, em certos casos, um pouco artificial, além, é claro, das desvantagens do método 3 , etapa anterior à vetorização. 
O resultado final usando-se o método 5 mostrou-se muito bom, porém é o método mais demorado quando o usuário não tem familiaridade com o programa. Outra desvantagem é que a artificialidade do desenho torna-se ainda mais acentuada do que a resultante do método 4. Este método apresenta algumas diferenças em relação ao anterior, entre elas o fato de que ao vetorizar um desenho já pronto, o traço pode apresentar variações de espessura ao longo de seu comprimento, enquanto desenhar diretamente usando vetores pode-se deixar o traço inteiro sem essa variação. Uma vantagem do uso do programa Corel Draw é que o tamanho do arquivo final (.cdr) é muito menor do que o resultante da vetorização pelo Adobe Ilustrator.

Avaliando o tempo gasto e a qualidade da ilustração final, o método 4 mostrouse ser o mais indicado para os desenhos onde apenas os traços são representados; já, quando há efeitos de sombras, o melhor método foi digitalizar a figura já finalizada à lápis e depois ajustar apenas os níveis de contraste e brilho no Photoshop (método 1).

O quinto método, apesar de ser o mais demorado, mostrou-se muito eficiente na ilustração de esquemas, já que estes não apresentam detalhes e, após o tratamento, ficam com um acabamento muito mais harmonioso.

\section{ETIMOLOGIA E NOMENCLATURA}

Em sua descrição original, Latreille não justifica a escolha do nome "morion" para o novo gênero criado.

De acordo com o Grand Dictionnaire Universel (Larousse), entre alguns significados referentes a castigos militares, "morion" é um substantivo masculino e significa um capacete usado durante os séculos XVI e XVII (fig. 65e). Tal capacete possui uma crista dorsal e prolonga-se nas bordas anteriores e posteriores. Em português este capacete chama-se morrião.

Em geologia, "morion" ou "quartzo morion" é uma variedade de quartzo esfumaçado, de cor castanha escura a negro e opaco, resultante da radiação artificial ou natural de quartzo leitoso contendo alumínio em sua composição. (fig. 65a) (http://en.wikipedia.org/wiki/Main_Page).

De acordo com o Novíssimo Diccionário Latino-Portuguez (Quicherat), "morion" pode ser um substantivo feminino, significando certa pedra preciosa 
(provavelmente "quartzo morion") ou um substantivo neutro, tendo o significado de grão de mandrágora (fig. 65b).

De acordo com o dicionário Houaiss da língua portuguesa, a palavra grega "morion" quer dizer parte, parte do corpo ou membro. O dicionário contido no livro "A Source Book of Biological Names and Terms" (Jaeger, 1955) diz que a palavra grega "morion" se refere também a uma outra planta tóxica da família Solanaceae, a Beladona (nightshade) (fig. 65d).

Há também uma planta chamada Madragora morion (fig. 65c).

Sabendo-se essas definições, pode-se observar que os dois primeiros significados para "morion" e o significado referente à planta Beladona podem estar atrelando o nome do grupo em questão a características morfológicas deste. Relacionando-se ao significado de um capacete indica-se que o corpo é bastante duro e protegido (élitros); relacionando-se com o mineral, além de indicar que o táxon é composto por indivíduos com uma carapaça rígida (dureza do mineral), indica também a cor escura dos indivíduos pertencentes ao grupo; referindo-se à Beladona pode se fazer uma comparação com a cor preta do fruto dessa planta. Já se relacionando com o prefixo grego e demais significados, nenhuma informação é fornecida ao grupo.

$\mathrm{Na}$ descrição original do gênero, o epípeto específico monilicornis não é alterado, deixando subentendido que Morion é um substantivo masculino ou feminino. Isto é confirmado pelo histórico apresentado, já que muitos autores consideram Morion como feminino ou masculino (colocando sufixo -is) e outros estritamente masculino (sufixo -us).

Segundo o Código Internacional de Nomenclatura Zoológica, o epíteto específico deve ser corrigido se este não concordar em gênero com o nome genérico (Artigo 34). Como não se sabe ao certo a que se referia Latreille quando deu o nome ao gênero, e, devido à confusão nomenclatural, ficou decidido atribuir um significado para que a nomenclatura do gênero fosse padronizada.

Por ser o mais informativo para o grupo (conforme mencionado acima), o significado de pedra preciosa (quartzo morion) foi atribuído ao nome morion. Desse modo, morion é feminino e seguirá a lista de nomes mencionada para este caso (Morion monilicornis, Morion brasiliensis, Morion boliviensis, Morion cordata, Morion cycloma, Morion costigera, Morion simplex, Morion lafertii e Morion arida). 
Nas descrições originais analisadas de cada espécie, os autores também não justificam as escolhas dos nomes. A fim de buscar o significado do nome da cada espécie para a elaboração da etimologia, alguns dicionários (inglês, português, latim, grego) foram consultados e esses significados comparados com as descrições e locais de coleta dos espécimes. Quando nenhuma relação foi encontrada, não foi possível propor uma explicação para a escolha de tal nome pelo autor.

\section{REDESCRIÇÕES}

As redescrições foram baseadas nas ilustrações e no material biológico disponível.

Para cada espécie foram apresentadas a lista de referências, lista sinonímica, etimologia (quando possível), diagnose e lista do material examinado com os dados de coleta.

As redescrições foram baseadas nas análises de estruturas externas e internas, seguindo a direção da cabeça para o ápice do abdômen.

Apenas os caracteres que não apresentaram grandes variações intraespecíficas foram considerados. Os casos em que houve dúvida a respeito de sua constância dentro da espécie foram discutidos após a redescrição.

Foram utilizadas medidas (na determinação do comprimento máximo e mínimo das espécies) e relações entre medidas na caracterização de certas estruturas. Para fazêlas foi utilizada uma régua milimetrada, sendo o erro associado de $0,5 \mathrm{~mm}$, metade da menor escala disponível no instrumento. Deste modo, as medidas foram sempre arredondadas para um número inteiro. Quando as medições foram feitas com o uso de um microscópio, uma lâmina milimetrada foi utilizada; neste caso o erro associado foi de $0,05 \mathrm{~mm}$, pois a escala desse instrumento é de $0,1 \mathrm{~mm}$.

A nomenclatura utilizada foi baseada em Sharp and Muir (1912) e Deuve (1993) para a genitália masculina, Tanner (1927) e Deuve (1993) pra a genitália feminina, Reichardt (1977), Lawrence \& Britton (1994) e Martinez (2005) para a morfologia geral de Carabidae, Jorge-Silva (1979) (tese não publicada) para as peças bucais e KukalováPeck (1993) para a asa membranosa. 
Para a elaboração da diagnose de cada espécie, somente as características que definem tais espécies (autapomorfias) deveriam ser utilizadas, segundo o conceito mais estrito de diagnose (conceito cladístico). Porém, a fim de usar a diagnose como ferramenta facilitadora no reconhecimento das espécies, foram utilizadas combinações únicas dos caracteres mais fáceis de serem observados, seguindo o conceito de Ridley (1996), pois, em muitos casos, as características exclusivas, quando identificadas, são de difícil localização.

\section{CHAVE DICOTÔMICA DE IDENTIFICACC̃̃O}

Foi construída uma chave dicotômica para identificação das espécies utilizando os principais caracteres diagnósticos de cada espécie, priorizando as estruturas externas e de maior facilidade de identificação.

Algumas características difíceis de serem mensuradas, mas apenas comparáveis, deixaram de ser usadas na chave de identificação, pois se o pesquisador não tiver pelo menos duas das espécies as quais a característica é comparável, não é possível avaliar o caráter. Um caráter não utilizado, por exemplo, foi a diferença na sexta interestria elitral de M. simplex e M. lafertii, que é levemente e fortemente costiforme, respectivamente, caráter difícil de mensurar.

\section{ELABORAÇ̃̃O DA LISTA DO MATERIAL EXAMINADO}

Conforme mencionado, após cada redescrição, segue uma lista do material examinado.

Para a elaboração desta lista, foram seguidos os seguintes critérios: os nomes dos países foram escritos em letra maiúscula seguido por um hífem, a ordem obedecida foi do país localizado mais ao norte para o mais ao sul; quando, devido à grande diferença de tamanho, houve sobreposição dos países, aquele que tem seu extremo norte mais ao norte geográfico foi colocado primeiro.

Logo após o hífem segue o nome do estado (sublinhado e seguido por um sinal de "dois pontos"); a ordem de citação segue o mesmo critério dos países. Após a 
marcação de "dois pontos" aparece o nome do município em ordem alfabética, exceto quando há comarcas; neste caso as comarca antecedem os município, são separadas destes por vírgula e seguem a ordem alfabética. Quando há algum outro ponto de referência mais específico dentro do município, esta localidade vem após o nome do município, seguido novamente por vírgula. As coordenadas geográficas aparecem entre parênteses após a localidade a qual pertence: se a coordenada se refere ao município, então aparece logo após este, já se faz referência à localidade mais específica, virá na frente desta.

Ao final dos nomes relacionados à localidade, segue-se a data de coleta, também separada por vírgulas e o nome do coletor, sempre com a abreviação "col." à frente do nome. Após o coletor, quando disponíveis, seguem respectivamente (entre vírgulas) o nome da coleção e dado de coleta (ex. espécime coletado em troncos de árvore). Por fím seguem o número de exemplares de cada sexo e a abreviatura da instituição (entre parênteses); os machos são representados por " $M$ ", as fêmeas por " $F$ " e os espécimes os quais o sexo não foi definido por "ex.” (exemplar).

Todos os dados relacionados às localidades que não estavam explícitos na etiqueta, mas que foram deduzidos posteriormente estão entre colchetes.

\section{CONSTRUĊ̃̃O DOS MAPAS DE DISTRIBUIÇÃO GEOGRÁFICA}

Os mapas da distribuição geográfica de cada espécie foram baseados nas localidades obtidas nos rótulos dos exemplares examinados e em dados da literatura.

Para construção dos mapas foi usado o programa ArcView versão 3.3 e para a localização das coordenadas geográficas Atlas e Gazetteer (impresso e on-line) foram consultados. Quando as coordenadas não foram localizadas, colegas de trabalho também foram consultados. A distribuição de Morion baseada na literatura segue o trabalho de Allen de 1968.

Devido à baixa resolução gráfica do mapa resultante da versão utilizada do programa Arcview (3.3) (o que resultaria em uma péssima qualidade de impressão), um mapa base foi desenhado digitalmente em alta resolução através do programa Photoshop com o auxílio de uma mesa digitalizadora. Posteriormente, cada mapa em baixa resolução foi ampliado digitalmente com o mesmo programa e sobreposto ao mapa 
base. Deste modo ficou relativamente fácil marcar os pontos obtidos pelo Arcview no mapa base.

Quando dispunha apenas da informação do país ou estado, sem qualquer outra informação mais específica, esse exemplar foi plotado com um círculo aberto, um pouco maior do que os pontos específicos, no centro do local. Quando o estado ou país já tinha sido representado no mapa por indivíduos com informações mais específicas, o círculo aberto não foi colocado, pois já havia representantes de tal região. As localidades específicas foram plotadas com círculo fechado.

Foram feitos 3 tipos de mapas: com dados encontrados na literatura, com dados obtidos no material analisado no presente estudo e posteriormente os mapas unindo ambas as informações. Para cada tipo de mapa foram feitas pranchas com a distribuição geográfica de cada espécie e um mapa colorido onde todas as informações foram reunidas. Posteriormente encontra-se uma prancha com todos os mapas das espécies em tamanho reduzido e, no centro, o mapa colorido ilustrando a junção das informações contidas nos mapas menores (prnachas 53, 58 e 64). Esta prancha foi feita com a finalidade de facilitar a comparação de todos os mapas específicos, porém, foi visto ser inadequado disponibilizar apenas essas pranchas comparativas, pois, embora visíveis, os pontos ficaram muito pequenos devido ao tamanho reduzido dos mapas das espécies. Nota-se na prancha 60 que em M. brasiliensis todas as localidades obtidas da literatura coincidem com parte das localidades dos exemplares examinados, deste modo só é visível os pontos referentes aos indivíduos do material examinado no presente trabalho. 


\section{RESULTADOS}

\section{Redescrições}

\section{Morion Latreille, 1810}

Morion Latreille, 1810: 159; Shenkling, 1925: 479 (cat.); Blackwelder, 1945 (cat.): 33; Allen, 1968: 142; Will, 2003: 225.

Morio Lamark, 1817: 510; Lacordaire, 1854: 183; Chaudoir, 1880: 327; Chevrolat, 1841: 1 (sin.); Shenkling, 1925: 479 (sin.) (cat.).

Espécie-tipo: Harpalus monilicornis Latreille, 1806: 206, designação por monotipia.

Etimologia: morion: latim (=certa pedra preciosa). O nome refere-se à rocha quartzomorion, destacando a carapaça rígida e negra dos exemplares do grupo.

Diagnose: corpo aproximadamente quatro vezes mais longo do que largo; antenas moniliformes com comprimento de aproximadamente duas vezes o da cápsula cefálica; cabeça com lobos frontais de tamanho moderado; labro com seis cerdas na margem anterior; mandíbulas assimétricas, dente mental com dois lobos bastante evidentes; margem anterior do pronoto mais larga do que a margem posterior; margens laterais dos élitros paralelas.

\section{REDESCRIČ̃̃O (para os espécimens do Novo Mundo):}

Aspecto geral (pranchas 01, 02 e 03): Coloração de marrom a preto brilhante, comprimento variando de $12-26 \mathrm{~mm}$, aproximadamente quatro vezes mais longo do que largo; corpo bastante esclerotizado e ligeiramente convexo.

Antena (prancha 04): moniliforme, com 11 antenômeros e cerdas douradas; escapo mais longo que os demais antenômeros, com ou sem cerda dorsal no terço proximal; antenômero 2 curto, arredondado, com poucas cerdas; antenômeros 3-4 alargando-se em direção ao ápice, sendo este último com cerdas mais concentradas na região distal; 
antenômeros 5-10 achatados, transversos, subretangulares e com grande concentração de cerdas curtas, algumas mais longas e eriçadas, principalmente próximo da região mediana; região mediana ventral e dorsal glabra; antenômero 11 com ápice arredondado e cerdas em toda margem, inclusive na região mediana apical.

Cabeça (fig. 05a; pranchas 06 e 07): Subquadrangular, bastante rígida, região mediana com dois sulcos sigmóides (sulcos frontais) saindo da linha fronto-clipeal indo até a altura mediana dos olhos ou até a margem posterior destes, mais profundo na região médio-anterior. Duas cerdas supraorbitais de cada lado em pontuação evidente. Clípeo parcialmente fundido à fronte, separado desta por fraca sutura, sendo mais visível na região mediana, liso ou ondulado, com 2-4 dentes e 1 cerda em cada lado da margem anterior. Olhos laterais encaixados na parte anterior de uma projeção laterobasal da cabeça, ocupando aproximadamente $2 / 3$ desta projeção. Lobo frontal acompanha a margem interna dos olhos.

Labro (prancha 08): subretangular, ligeiramente mais largo que longo; margem anterior fortemente escavada no meio tornando-se bilobada, cada lobo com a largura de aproximadamente um terço da altura; região mediana anterior convexa. Marginado anteriormente por uma fileira de 6 cerdas longas e espessas inseridas em pontos grossos. A partir dessa fileira, a superfície dorsal declina-se em direção ao ápice.

Epifaringe (prancha 08): fortemente escavada na região mediana anterior; cada lado com fileira inclinada de cerdas espessas, partindo dos ângulos anteriores em direção à região mediana diminuindo de comprimento em direção ao centro. As fileiras de cerdas estão em carenas curvas que se juntam e torna-se mais pronunciada na região mediana; há muitos botões sensoriais de cada lado próximo à base; região mediana basal com microtríquias e dois grupos de botões.

Mandíbula direita (fig. 09c, 09d; pranchas 10, 11, 12 e 13): subtriangular, robusta com ápice arredondado; largura um pouco maior que a metade do comprimento; região molar curta com dois dentes robustos e arredondados, sendo o basal estriado na região lateral interna; dente interno ventral desenvolvido e bilobado com lobo anterior muito menor que o posterior; região dorsal com pequeno dente terebral arredondado na margem interna, próximo à região molar. Aparelho filtrador formado por fileira de cerdas curtas, situado ventralmente, próximo à margem interna, indo do dente que precede o retináculo até o dente basal da região molar. Forte depressão subtriangular basal próxima ao dente estriado na região ventral. $\mathrm{O}$ escrobo glabro na margem externa 
é mais visível em vista dorsal. Região médio-basal achatada na superfície dorsal e ventral.

Mandíbula esquerda (fig. 09a, 09b; pranchas 14, 15, 16 e 17): subtriangular, côncava ventralmente, largura igual ou menor que a metade do comprimento, sendo um pouco mais afilada e longa e com ápice mais curvo do que a mandíbula direita, margem externa bastante curva; dente pré-molar desenvolvido, dente terebral mais desenvolvido do que na mandíbula direita; região molar com dois dentes, sendo o basal com base estriada; dente terebral pequeno e arredondado, que se encaixa entre o dente pré-molar e o dente interno ventral da mandíbula direita. Aparelho filtrador semelhante ao da mandíbula direita. Forte depressão subtriangular basal próxima ao dente molar estriado na região ventral (como na mandíbula direita). Região médio-anterior com leve depressão, mais acentuada na região ventral.

Maxilas (prancha 18): simétricas. Gálea palpiforme bissegmentada com ápice arredondado portando papilas sensoriais apicais; segmentos cilíndricos, sendo o basal com região distal mais robusta; segmento distal ligeiramente curvo. Lacínia com ápice unciforme, com uma cerda mais espessa na margem interna; cerdas marginais longas formando densa franja dorsal; ventralmente com duas cerdas próximas ao meio e muitas cerdas finas no terço basal. Palpífero com projeção distal e uma cerda longa látero mediana. Estipe dividido: basiestipe com uma cerda e medioestipe glabro. Palpo com quatro palpômeros; primeiro curto e curvado para a margem externa; segundo mais longo, robusto e curvado para a margem interna; terceiro mais curto que o segundo e mais longo que o primeiro; quarto palpômero longo, cilíndrico, ligeiramente mais estreito nas extremidades. Cardo mais longo que largo, tendo aproximadamente a metade do comprimento do palpo, progressivamente mais robusto da base para o ápice.

Lábio (fig. 05b; prancha 19): lobo mediano forma uma forte carena longitudinal mediana com duas cerdas longas no terço anterior (cerdas distais) e ventralmente com 3 dentes, sendo o mediano voltado para cima e bastante desenvolvido; palpos labiais simétricos e com três palpômeros; palpígero mais longo que o primeiro palpômero que é mais curto e encurvado para fora; segundo palpômero longo, cilíndrico, alargando-se em direção ao ápice e apresenta duas cerdas dorsais; palpômero terminal cilíndrico; membrana mental visível na base do palpígero; mento com dente bilobado e duas cerdas pós-dentais; dois orifícios cilíndricos na base interna dos lobos; ventralmente, a distância epilobo-sutura tem aproximadamente um terço da distância epilobo-ápice do 
lobo; carena na margem dos lobos indo até a base do dente do mento; ventralmente os lobos mentais têm muitos botões sensoriais. Hipofaringe com grande concentração de microtríquias nas laterais e na altura do epilobo; paraglossa membranosa semitransparente com microtríquias que vão até o ápice.

Tórax (pranchas 02, 03, 20, 21, 22 e 23): pronoto subquadrangular, levemente convexo, margem anterior menor que a posterior, margens laterais ligeiramente sinuosas próximo à base com sulco paralelo formando estreita borda lateral com cerdas ao longo das margens, sendo a última no ângulo posterior; ângulos anteriores levemente arredondados e convergentes e os posteriores curtos, levemente divergentes; linha média moderadamente acentuada e fóveas basais mais fortemente acentuadas. Prosterno projetado para baixo, processo intercoxal com ápice arredondado; margens anteriores e posteriores com fileira de cerdas curtas. Mesosterno curto. Metepisterno estreito e longo, sendo mais largo anteriormente; metepímero pequeno e subcircular; suturas metapleurais visíveis, mais acentuadas na região mediana.

Escutelo: pequeno, pentagonal e fortemente encaixado nos élitros.

Perna anterior (pranchas 24, 25, 26, 27 e 28): trocânter com uma cerda na margem interna. Fêmur globoso, mais largo na região mediana; cerdas esparsas e depressão longitudinal ventral, mais acentuada próximo ao ápice que é arredondado. Tíbia brevemente mais longa que o fêmur, afilada na base, alargando-se em direção ao ápice; margem externa estende-se no ápice formando uma projeção bastante pronunciada, levemente encurvada para baixo que se estende até aproximadamente a altura do tarsômero 2; projeção com cerdas curtas e grossas na margem externa, margem interna da tíbia com recorte arredondado no terço apical no limpador de antenas e forma um lobo arredondado dorsalmente no ápice. Superfície dorsal com uma fileira de cerdas do limpador de antenas até aproximadamente o quarto proximal, acompanhado de um leve sulco que vai até próximo à base da tíbia; margem interna anterior ao limpador de antenas com fileira de cerdas que segue até o ápice, cobrindo parcialmente o esporão apical. Ventralmente, próximo ao ápice, uma projeção mediana com uma cerda curta e grossa apical e uma projeção em forma de espinho próximo à margem interna; região mediana com fileira de cerdas e margem interna com uma fileira de cerdas finas da base do limpador de antenas até próximo à base da tíbia. Limpador de antena na região subapical interna da tíbia; margem côncava arredondada marginada por franja de cerdas, sendo a cerda que está na base, mais longa; região distal com cerdas 
ventrais; saindo da base um esporão ventral levemente sinuoso. Tarso pentâmero com tarsômeros progressivamente menores do primeiro ao quarto, mas com o quinto mais longo e com ápice dilatado, portando duas fortes garras simples, curvas, com 2 cerdas látero-dorsais e algumas ventrais. Tarsômeros $1-4$ com poucas cerdas ventrolaterais, sendo que o 1 e 2 apresentam dente na margem externa (pelo menos nos machos), maior no tarsômero 1.

Perna mediana (pranchas 29, 30, 31 e 32): coxa, em vista dorsal, com poucas cerdas. Trocânter com uma cerda ventral próximo ao ápice. Fêmur globoso, mais largo na região mediana com cerdas mais concentradas próximo à região dorso-apical; depressão longitudinal ventral, mais acentuada próximo ao ápice que é arredondado. Tíbia achatada lateralmente, gradualmente alargada para o ápice, e ligeiramente encurvada para dentro; ventralmente com três fileiras longitudinais de cerdas espessas, uma na margem externa, uma próxima ao meio em carena leve e uma fileira de cerdas mais longas na margem interna; dorsalmente com forte carena levemente sinuosa próximo à margem externa e duas fileiras longitudinais de cerdas mais longas, uma próxima à margem interna e outra na região mediana; cerdas de tamanho variado concentradas próximo à região distal-interna; margem distal com fileira de cerdas espessas e longas e cerdas esparsas próximo ao ápice; 2 esporões tibiais bem desenvolvidos. Tarsos como nas pernas anteriores.

Perna posterior (pranchas 33, 34, 35 e 36): coxa subtriangular com 2-3 cerdas ventrais; trocânter subtriangular com uma cerda sempre presente em uma depressão no terço proximal da superfície ventral. Fêmur globoso, mais largo próximo à região mediana, com poucas cerdas esparsas; depressão longitudinal ventral, mais acentuada próximo ao ápice que é arredondado. Tíbia estreita, levemente alargada em direção ao ápice; dorsalmente há um leve sulco e um sulco bastante acentuado na margem externa que se acentua em direção ao ápice, onde forma um pequeno dente apical; quatro fileiras longitudinais de cerdas: ventralmente três fileiras, sendo a da margem externa curta, a mediana com cerdas espessas indo de próximo ao ápice até o quarto anterior em um sulco que vai até a base e a na margem interna com o mesmo comprimento, mas com cerdas mais finas; dorsalmente uma fileira de cerdas próxima à margem interna, ápice com maior concentração de cerdas, margem apical contornada por cerdas e ventralmente por cerdas mais grossas; dois esporões apicais com aproximadamente o comprimento do primeiro tarsômero. Tarsômeros 1-4 cilíndricos, levemnte achatados, 
com cerdas no ápice, sendo essas mais concentradas ventralmente; tarsômero 5 mais longo e mais largo no ápice com duas garras simples e glabras.

Asa membranosa (pranchas 37 e 38): desenvolvida ou atrofiada; quando desenvolvida aproximadamente 3 vezes mais longa do que larga; lobo anal arredondado e ápice mais afilado; veia anal (AA) divide-se próximo da base, ramo proximal $(\mathrm{AA} 3+4)$ segue até a margem enquanto o outro $(\mathrm{AA} 1+2)$ junta-se com a cúbito anterior $(\mathrm{CuA})$ na altura mediana, seguindo juntas até a margem, sem formação de célula. Média posterior (MP-) longa, com um ramo saindo do meio (dando origem à MP3 e MP4) e estendendo-se além do meio do comprimento alar, curvando-se para cima antes de se juntar com a radio posterior (RP). RP1 não se estende além da veia transversal $r 4$. Ramo mp-cua forma com a base alar uma célula mais esclerotizada; este ramo pode não estar visível, ou incompleto. Célula oblonga estreita, podendo estar ligeiramente incompleta.

Élitros (39 e 40): margens laterais paralelas; região subapical com declive moderadamente acentuado; sete interestrias fracamente pontuadas mais a sutural. Estrias marcadas por sulcos e interestrias levemente convexas; apenas a primeira e segunda interestrias chegam até o ápice, as demais se juntam ou terminam anteriormente próximo ao ápice. Margem pontuada com fileira única de cerdas, exceto próximo ao ápice onde a concentração pode ser um pouco maior. Próximo às margens laterais do escutelo, na base da primeira estria, há uma cerda em cada élitro. Ápice arredondado e enrugado.

Abdome (pranchas 20, 22 e 23): Ventrito 1 glabro. Ventrito 3 com 2 ou mais cerdas próximas à margem posterior. Ventritos 4 e 5 com duas cerdas na região mediana, próximas à margem posterior e ventrito 6 com 2 à 8 cerdas próximas ao ápice dispostas em dois agrupamentos. Sutura entre ventritos 2 e 3 fracamente visível na região mediana.

Segmentos genitais masculinos (fig. 41c; prancha 42): Esternito VIII mais largo do que longo, esclerotizado, sendo mais fracamente na região médio-basal; com duas projeções basais (apódemas) levemente encurvadas para dentro com tamanho de $1 / 4$ a $1 / 3$ do comprimento do ventrito; estrutura coberta por microtríquias, com maior concentração nas margens apical e látero-apicais onde há finas cerdas; duas faixas médio-laterais transversais mais esclerosadas vão desde a base das projeções basais até o terço distal do ventrito. Lateralmente estão os espiráculos. Tergito VIII formado por dois laterotergitos unidos no meio por fina membrana. Tergito IX formado por uma 
região antecostal, um médio tergito e dois laterotergitos; a região antecostal tem forma de arco e o mediotergito IX é retilíneo e menor; os dois juntos compõem uma forma subtriangular, membranosa, com margem mais esclerosada e ápice levemente rugoso e afilado. Laterotergitos IX fracamente esclerosado situado entre a região antecostal e o mediotergito IX; preso apenas em uma das extremidades, funcionando como uma porta por onde passa o lobo médio.

Segmentos genitais femininos (pranchas 47 e 48): esternito VIII como no macho; tergito IX formado por 2 laterotergitos em forma de placa subretangular, mais escleritizados na região proximal; esternito IX membranoso e aparentemente funde-se com o décimo. Décimo esternito membranoso com algumas cerdas no ápice por toda a extensão.

Edeago (pranchas 43, 44, 45 e 46): lobo médio cilíndrico, curvo para baixo e distalmente com leve desvio para a direita; região proximal arredondada podendo apresentar uma pequena projeção laminar; região distal afilada com ponta pós orifício mediano podendo ser curta ou longa; orifício mediano estende-se até o terço distal. Há dois parâmeros assimétricos encaixados na região próximo-ventral que se prendem ao lobo mediano do pênis por finas membranas; o parâmero voltado para a esquerda é mais largo, deprimido com margem mais alta e há uma projeção que passa por cima do parâmero com região distal mais larga; o parâmero voltado para a direita é mais afilado e tem forma de "L" com um prolongamento laminar na região mediana; região distal cilíndrica com ápice arredondado.

Genitália feminina (pranchas 47 e 48): styli bastante esclerosados, encurvados para fora, com base larga, dois dentes na margem externa e um dorsalmente próximo à margem interna; valvíferos globosos com cerdas no ápice; coxitos subquadrangulares com margens mais esclerosadas e ápice mais largo.

\section{Discussão:}

Aspecto geral: a coloração pode variar de marrom claro ao preto brilhante, pois indivíduos recém eclodidos são mais claros, tornando-se escuros após um determinado tempo.

Cabeça: de forma geral a cabeça em todas as espécies são semelhantes, porém os sulcos frontais podem variar intraespecificamente em profundidade e extensão. Para 
Allen (1968), uma das características que diferencia M. boliviensis de outras espécies de Morion é o fato de os sulcos frontais irem apenas até a altura da borda anterior dos olhos. Embora essa característica seja válida para tal espécie, foram vistos espécimens de M. cycloma com tais sulcos tão curtos quanto em M. boliviensis e outros com sulcos que se estendem até a altura da borda posterior dos olhos. Portanto esse caráter varia intraespecificamente. A sutura fronto-clipeal dos Morion do Novo Mundo também pode ser mais ou menos acentuada dentro de uma mesma espécie.

Labro e epifaringe: em todas as espécies não foram observadas diferenças significativas que pudessem ser consideradas específicas. Em alguns exemplares os lobos apresentam pequena variação no arredondamento. As pontuações de onde as cerdas estão inseridas também variam em relação a sua profundidade. Também há variação no número de cerdas da epifaringe.

Mandíbulas: por ser uma estrutura que está freqüentemente em atrito, as mandíbulas podem variar muito intraespecificamente, principalmente no tamanho dos dentes e da porção apical (dente apical), que pode ser mais ou menos arredondada. Normalmente os indivíduos mais jovens (com coloração mais clara) possuem os dentes maiores, menos arredondados e sem sinais de quebra ou desgaste. Deste modo é muito difícil encontrar um padrão que caracterize uma determinada espécie.

Lábio: foram vistas pequenas variações no tamanho dos lobos mentais e dentes do mento, provavelmente devido a desgastes físicos. O termo lobo mediano foi utilizado, pois se refere apenas às glossas fundidas em uma única peça. Segundo a tese não publicada de Jorge-da Silva de 1979, muitos carabidólogos usam erroneamente o termo lígula para se referir ao lobo médio (apenas glossas fundidas), porém a definição de lígula é: o nome dado ao conjunto glossas e paraglossas, fundidas ou não (Torre-Bueno 1989). Se as paraglossas estivessem ausentes o termo lígula poderia ser usado para se referir ao lobo mediano, porém estas estão presentes, mas não fundidas (Jorge-da Silva 1979). A lígula ou pré-mento é uma parte móvel do lábio e pode retrair-se sobre o mento, deste modo em alguns exemplares os palpígeros não estavam visíveis e o lobo mediano e paraglossas pareciam menores, como ilustrado na figura $19 \mathrm{~b}$.

Tórax: pode haver variação no número de cerdas que margeiam o pronoto; a quantidade de cerdas na região ventral, quando presentes, varia bastante, não havendo simetria. 
Perna anterior: por viverem sob cascas de troncos, suas pernas anteriores, principalmente as tíbias, sofrem bastante atrito. Deste modo, alguns exemplares apresentam as cerdas ventrais fracamente visíveis ou até ausentes, porém nestes casos, é perceptível que a tíbia como um todo está muito desgastada, pois até mesmo a projeção externa está bastante encurtada e arredondada. Há variação intraespecífica no número de cerdas, não possibilitando atribuir uma quantidade exata para cada espécie; o número de cerdas nas diferentes espécies se sobrepõe.

Perna mediana: há variação intraespecífica no número de cerdas das distintas fileiras.

Perna posterior: há variação intraespecífica no número de cerdas.

Asa membranosa: ocorre braquipteria em duas das nove espécies do Novo Mundo. Nas asas desenvolvidas, as principais diferenças estão na célula oblonga e no ramo transversal médio-cubital (mp-cua). Este ramo é importante e situa-se entre as veias MP e $\mathrm{CuA}$, perto da base. Ocorre em asas anteriores e posteriores, sendo uma sinapomorfia básica compartilhada pelos Endopterygota e os hemipteróides. A mp-cua dos coleópteros é atravessada por uma profunda dobra médio-cubital e está freqüentemente ausente. Ela é preservada em alguns Adephaga e é bastante rara em Polyphaga; provavelmente foi eliminada em Archostemata (derivados) (Kukalová-Peck \& Lawrence 1993). Entre os Morion há variação em seu tamanho e posição, podendo não estar visível, sendo visível apenas a célula mais esclerotizada próxima da base.

Élitros: Pode haver alguma variação intraespecífica na disposição das cerdas e no comprimento e disposição das estrias na margem externa, próximo ao ápice. Algumas estrias podem estar mais próximas e pode haver variação no comprimento.

Abdome: Há grande variação intraespecífica em relação ao número de cerdas presentes no sexto ventrito, deste modo, foi decidido não utilizar este caráter nas redescrições específicas, diferentemente do trabalho de Allen, 1968.

Segmento genital masculino: há poucas diferenças nos segmentos das espécies estudadas; são estruturas membranosas e de difícil caracterização. É visível leve variação no comprimento e largura dos apódemas basais do esternito VIII.

Edeago: em seu trabalho de 1968, Allen diz que a morfologia do edeago varia apenas em M. brasiliensis, M. boliviensis e M. cycloma, porém é bastante visível, inclusive em suas próprias ilustrações, diferenças nos edeagos de quase todas as espécies conforme as redescrições e discussão do presente trabalho. 
Genitália feminina: foi encontrado em um espécime de $M$. brasiliensis valvíferos pouco evidentes e glabros.

A distribuição geográfica dos Morion das Américas vai desde o sul do Brasil (Rio Grande do Sul) até o Norte dos Estados Unidos (Dakota do Sul) e já foram coletados em todos os meses do ano.

Diversos exemplares foram capturados com armadilha luminosa, luz negra, luz mista e Malaise, além de coleta manual e com auxílio de rede entomológica. Alguns espécimens foram encontrados em ninhos de Atta sp.

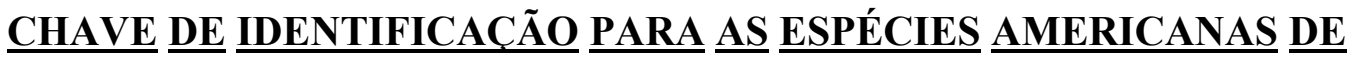 MORION (ADULTOS)}

1. Pronoto com fileira de cerdas na margem anterior

1.1. Pronoto sem fileira de cerdas na margem anterior

2. Metatrocânter com comprimento maior do que a metade do comprimento do metafêmur; ramo alar mp-cua não visível Morion simplex

2.1 Metatrocânter com comprimento menor do que o comprimento do metafêmur; ramo alar mp-cua perfeitamente visível e completo 3

3. Prosterno com cerdas apenas na base do processo prosternal

Morion monilicornis

3.1. Prosterno com cerdas esparsas, sendo mais concentradas perto das margens anteriores da pró-coxa

4. Metatrocânter com ápice arredondado, não formando ponta na margem interna; prosterno fortemente projetado para baixo; célula oblonga da asa membranosa fechada .

Morion arida

4.1 Ápice do metatrocânter formando ponta na margem interna; prosterno moderadamente projetado para baixo; célula oblonga da asa membranosa aberta

Morion cordata

5. Escapo glabro; pró-tíbia angulosa na região mediana; úmero arredondado; projeção mediana na margem interna do metafêmur formando ponta evidente 
5.1 Escapo com cerda; pró-tíbia quase reta; úmero com margem anterior reta; projeção mediana na margem interna do metafêmur, quando presente, não forma ponta evidente

6. Metatrocânter com comprimento maior do que metade do comprimento do metafêmur; sexta interestria elitral costiforme anteriormente; mesotíbia levemente encurvada para dentro, gradualmente mais larga da base para o ápice 7

6.1. Metatrocânter com comprimento menor do que o comprimento do metafêmur; mesotíbia fortemente encurvada para dentro com ápice muito mais robusto do que a metade anterior; sexta interestria elitral não costiforme

7. Cerdas esparsas no prosterno e próximo à margem anterior do metasterno; asa membranosa reduzida Morion costigera

7.1. Prosterno e metasterno glabros; asa membranosa desenvolvida

Morion lafertii

8. Metasterno glabro; terço basal da margem interna do metafêmur bastante dilatado formando um lobo; ramo alar mp-cua completamente visível; lobo médio com ponta pós orifício mediano quase reta Morion boliviensis

8.1. Metasterno com 1 ou 2 cerdas próximo ao processo intercoxal anterior e/ou posterior; terço basal do metafêmur não forma lobo pronunciado; ramo alar mp-cua não completamente visível; lobo médio com ponta pós orifício mediano fortemente encurvada para baixo Morion cycloma

\section{Morion arida Allen, 1968}

Morion aridus Allen, 1968: 146; Bousquet \& LaRochelle, 1993: 160 (cat.) (distr. geográfica).

Etimologia: aridus: latim (=seco). Na descrição original Allen não justifica a escolha deste epíteto específico, mas, analisando as localidades dos exemplares estudados por ele, pode-se supor que o nome se refere ao tipo de ambiente onde os indivíduos pertencentes a esta espécie foram coletados. 
Diagnose: clípeo com quatro dentes na margem anterior, pronoto sem cerdas na margem anterior; superfície ventral do tórax com cerdas no prosterno, mesosterno e metasterno; élitros com interestria 6 não costiforme próximo à base; metatrocânter mais curto que a metade do comprimento do metafêmur e com ápice arredondado.

\section{REDESCRIĊÃO:}

Nota: Devido à falta de material, só foram observados exemplares fêmeas e fotos do holótipo (macho); as características dos machos foram retiradas principalmente do trabalho de Allen, 1968.

Aspecto geral (fig. 01a e 02a): Comprimento variando de $13-18 \mathrm{~mm}$.

Antena: escapo com 1 cerda na margem externa.

Cabeça (fig. 06a): Sulcos frontais profundos saindo da linha fronto-clipeal indo até a margem posterior dos olhos. Clípeo com quatro dentes na margem anterior.

Mandíbula direita (fig. 10a e 12a): Robusta, largura um pouco maior que a metade do comprimento; região molar curta com dois dentes robustos e arredondados. Relação da distância lobo posterior - base da região molar próximo a 1.

Mandíbula esquerda (fig. 14a e 16a): região apical semelhante nos machos e fêmeas.

Tórax (fig. 02a, 21a e 22a): margem anterior quase reta e cerdas presentes; relação largura/comprimento do pronoto menor que 1,35; linha média moderadamente acentuada e fóveas basais acentuadas; relação do tamanho fóvea/comprimento do pronoto maior que 0,25 . Prosterno fortemente projetado para baixo com cerdas esparsas; maior concentração próximo às margens das pró-coxas. Mesosterno curto, com cerdas. Metasterno com algumas cerdas esparsas, exceto na região mediana; metepisterno estreito e longo, sendo mais largo anteriormente.

Perna anterior (fig. 24a, 25a e 28a): Fêmur com cerdas esparsas, sendo uma na superfície externa próximo ao ápice; superfície interna lisa e glabra próximo à base. Tíbia não angulosa, com margem externa quase reta que se estende no ápice formando uma projeção bastante pronunciada com o ápice arredondado; superfície externa estriada ou não. Distância entre a base da tíbia e o esporão do limpador de antenas 
maior ou igual à distância deste e o ápice da tíbia. Tarsômeros progressivamente menores do primeiro ao quarto; tarsômero 1 com dente apical pronunciado na margem interna nas fêmeas; raramente tarsômeros 2 e 3 com cerdas escamiformes ventralmente nos machos (encontrado em apenas 1 exemplar).

Perna mediana (fig. 29a, 31a): Tíbia levemente encurvada para dentro, gradualmente alargada da base para o ápice.

Perna posterior (fig. 33a e 37a): trocânter subtriangular com ápice arredondado, não estreitado no ápice interno; comprimento inferior à metade do comprimento do fêmur. Fêmur com cerdas esparsas e uma cerda próximo ao ápice na superfície externa, margem interna sem projeção ou apenas fracamente acentuada, relação comprimento/ largura da região mediana inferior a 3. Fileira ventral mais curta da tíbia com aproximadamente 4 cerdas; cerdas ventrais esparsas próximo ao ápice da tíbia.

Asa Membranosa (fig. 38a): desenvolvida com comprimento de aproximadamente 0,8 do comprimento do habitus; relação comprimento/largura da asa de aproximadamente 2,6; relação comprimento do ramo mp-cua/comprimento da nervura MP1+2 de aproximadamente 6,4. Célula oblonga completa.

Élitros (fig. 39a): borda bem definida até o ápice; úmero tão largo quanto a lateral do élitro; interestira 6 não costiforme no terço anterior; estria sete perfeitamente visível e une-se com as terceira, quarta, quinta e sexta, seguindo até próximo ao ápice; apenas a primeira estria chega ao ápice; 1 a 3 cerdas em cada élitro entre a estria 1 e a sutura próximo ao ápice.

Abdome (fig. 22a): ventrito 2 com duas cerdas na região mediana.

Edeago (lobo médio) (fig. 44a): não foi possível examinar material, apenas fotos do holótipo, impossibilitando deste modo, uma redescrição precisa.

Material examinado:

ESTADOS UNIDOS - Arizona: Maricopa Co., Phoenix (33²6’54'N, 112 04’24”O), CollChasPalm, 1F (parátipo) (AMNH); 01.III.1920, E. Schiffel col., Coleção Borys Malkin Coleoptera, 1F (FMNH); Pima Co., Organ Pipe Cactus National Monument, 26.VIII.1966, George E. Ball e Ronald L. Madge, 1M (foto) (holótipo) $(\mathrm{MCZN}) ; 12$ milhas a oeste de Tucson $\left(32^{\circ} 11^{\prime} \mathrm{N}, 111^{\circ} 05^{\prime} \mathrm{O}\right), 05 . \mathrm{II} .1966, \mathrm{~J}$. D. Vertrees col., coletado em sahuaro [tipo de cacto] podre, 1F (AMNH); Tucson $\left(32^{\circ} 13^{\prime} 18^{\prime \prime} \mathrm{N}\right.$, 11055’33”O), 10.III.1906, F. W. Nunenmacher col., Coleção Nunenmarcher, 1F 
(FMNH). MÉXICO - Baixa Califórnia: Miraflores (2802’N, $\left.113^{\circ} 14^{\prime} \mathrm{O}\right), 10 . \mathrm{VII} .1938$, Michelbacher \& Ross col., 1F (asa dissecada) (parátipo) (MZSP).

\section{Discussão:}

Neste trabalho não foi possível examinar exemplares machos, apenas fotos. Allen (1968) examinou 27 espécimens de $M$. arida machos e observou dimorfismo sexual em apenas um exemplar. Este exemplar possui duas fileiras de cerdas escamiformes na superfície ventral dos tarsômeros anteriores 2-3 enquanto que as fêmeas não as possui. As margens laterais do pronoto de $M$. arida são mais paralelas do que nas outras espécies e o fêmur anterior é mais curto do que nas demais espécies, tornando-se mais globoso. Allen examinou 3 exemplares sem cerdas na margem anterior do pronoto e diz que o metatrocânter é igual em M. cordata, porém, como descrito acima, o ápice é arredondado, não formando uma ponta. Freqüentemente há rugosidade próximo ao ápice do fêmur posterior.

Sua distribuição geográfica é limitada ao sudoeste dos Estados Unidos e noroeste do México. Há registro de espécimens coletados nos meses: fevereiro, março, julho, agosto, novembro e dezembro.

\section{Morion boliviensis Allen, 1968}

Morion boliviensis Allen, 1968: 145.

Etimologia: Bolívia + -ensis: latim (=formador de adjetivos gentílicos). O nome indica que os exemplares utilizados na descrição original foram coletados em território boliviano.

Diagnose: sulcos frontais da cabeça indo apenas até a altura da base dos olhos; clípeo com quatro dentes na margem anterior, pronoto sem cerdas na margem anterior; superfície ventral do tórax às vezes apresenta cerdas apenas no mesosterno; élitros com interestria 6 não costiforme próximo à base; pernas anteriores dos machos com 
tarsômeros 1-3 portando 2 fileiras de cerdas escamiformes ventralmente; metatrocânter mais curto que a metade do comprimento do metafêmur.

\section{REDESCRIČ̃̃O:}

Aspecto geral (fig. 01b e 02b): Comprimento variando de 18 - $25 \mathrm{~mm}$.

Antena (fig. 04a): escapo com uma cerda na margem externa.

Cabeça (fig. 06b): sulcos frontais profundos indo apenas até a altura da margem anterior dos olhos. Clípeo com quatro dentes na margem anterior; margem anterior escavada na região mediana.

Mandíbula direita (fig. 10b e 12b): robusta, largura um pouco maior que a metade do comprimento; região molar curta com dois dentes robustos e arredondados. Relação da distância lobo posterior - base da região molar próximo a 1 .

Mandíbula esquerda (fig. 14b e 16b): região apical semelhante nos machos e fêmeas.

Tórax (fig. 02b, 21b e 22b): margem anterior invaginando-se na região mediana e cerdas ausentes; relação largura/comprimento do pronoto maior que 1,35 ; linha média moderadamente acentuada e fóveas basais acentuadas; relação do tamanho fóvea/comprimento do pronoto maior que 0,25 . Prosterno glabro e projetado para baixo. Mesosterno curto, raramente com cerdas. Metasterno glabro; metepisterno estreito e longo, sendo mais largo anteriormente.

Perna anterior (fig. 24b, 25b, 27a e 28b): Fêmur com cerdas esparsas, sendo uma na superfície externa próximo ao ápice; superfície interna com algumas estrias e cerdas próximo à base; terço basal da margem interna bastante dilatado, formando um pequeno lobo interno. Tíbia não angulosa, com margem externa quase reta que se estende no ápice formando uma projeção bastante pronunciada com o ápice arredondado; superfície externa pouco estriada. Distância entre a base da tíbia e o esporão do limpador de antenas maior ou igual à distância deste e o ápice da tíbia. Diferença de tamanho entre os tarsômeros 3 e 4, apenas nos machos, maior do que entre os demais tarsômeros que são progressivamente menores do primeiro ao terceiro; tarsômero $1 \mathrm{com}$ dente apical pronunciado na margem interna apenas nas fêmeas; tarsômeros 1-3 com cerdas ventrais escamiformes apenas nos machos. 
Perna mediana (fig. 29b e 31b): Tíbia levemente encurvada para dentro, gradualmente alargada da base para o ápice.

Perna posterior (fig. 33b e 35b): trocânter subtriangular com margem externa arredondada com formação de uma ponta no ápice interno; comprimento inferior à metade do comprimento do fêmur. Fêmur com cerdas esparsas e uma cerda próximo ao ápice na superfície externa, margem interna sem projeção ou apenas fracamente acentuada, relação comprimento/ largura da região mediana igual ou superior a 3 . Fileira ventral mais curta da tíbia com aproximadamente 4 cerdas; não há cerdas ventrais esparsas próximo ao ápice da tíbia.

Asa membranosa (fig. 38b): desenvolvida com comprimento de aproximadamente 0,8 do comprimento do habitus; relação comprimento/largura da asa de aproximadamente 2,6; relação comprimento do ramo mp-cua/comprimento da nervura MP1+2 de aproximadamente 6,4. Célula oblonga incompleta.

Élitros (fig. 39b): borda bem definida até o ápice; úmero tão largo quanto a lateral do élitro; interestira 6 não costiforme no terço anterior; estria sete perfeitamente visível e une-se com a terceira, quarta, quinta e sexta, seguindo até próximo ao ápice; apenas a primeira estria chega ao ápice; não há cerdas em cada élitro entre a estria 1 e a sutura próximo ao ápice.

Abdome (fig. 22b): ventrito 2 glabro.

Edeago (fig. 44b, 45a e 46a): lobo médio: quarto basal mais robusto que o quarto apical; ponta pós orifício mediano muito longa, levemente encurvada para baixo; orifício mediano extende-se até próximo ao terço anterior.

Material examinado: BRASIL - Roraima: Ilha de Maracá $\left(03^{\circ} 25^{\prime} \mathrm{N}, 61^{\circ} 40^{\prime} \mathrm{O}\right)$, Rio Uraricoera, 02-13.V.1987, J. A. Rafael, J. E. B. Brasil, L. S. Aquino col., armadilha de Malaise, 1F (INPA). Amazonas: Presidente Figueiredo, Estrada de Balbina km 12 Igarapé Santuário (0203’36”S, 5955’35”O), 19-30.IX.2003, Xavier Fo, F. F.; Vidal, J. M. col., 1F (INPA); Reserva-Dulke (02 $2^{\circ} 55^{\prime} 50^{\prime \prime S}$, 5958'27’O), 13.I.1978, R. C. Ratcliffe col., 1M (dissecado) (INPA). Pará: Belém (01²7’ S, 48 29'O), 1ex. (MNRJ); Benevides (0122'S, 48¹5'O), Morelândia, 27.I.1981, David col., 1M (MPEG). BOLÍVIA -Beni: Vila indígena Chacobo no Rio Benicito $\left(12^{\circ} 20^{\prime} \mathrm{S}, 66^{\circ} \mathrm{O}\right)$, 0110.VII.1960, B. Malkin col., 2F (recebidos dissecados) (parátipos) (FMHN). 


\section{Discussão:}

Apresenta dimorfismo sexual; os machos têm duas fileiras de cerdas escamiformes na superfície ventral dos tarsômeros anteriores 1-3 e a diferença de tamanho entre os tarsômeros 4 e 3 é maior do a diferença entre os demais tarsômeros.

M. boliviensis e muito parecida com M. cycloma. Para diferenciar as duas espécies é preciso verificar se o metasterno é glabro (M. boliviensis) e se a ponta pós orifício mediano do lobo médio é fortemente encurvada para baixo (M. cycloma).

Os sulcos frontais reduzidos (indo apenas até a altura da margem anterior dos olhos) é uma característica bastante marcante, como descrita no trabalho de Allen de 1968, porém não é exclusiva de M. boliviensis, já que também foi encontrada em alguns exemplares de M. cycloma.

Até 1968 a distribuição geográfica de M. boliviensis era restrita à Bolívia, porém, no presente trabalho a distribuição geográfica foi ampliada para a região norte do Brasil. Um espécime foi coletado com armadilha de Malaise.

Há registro de espécimens coletados nos meses: janeiro, maio, julho, setembro, novembro e dezembro.

\section{Morion brasiliensis Dejean, 1825}

Morion brasiliensis Dejean, 1821: 866 (cat.) [n.n.]; 1825: 432; Chaudoir, 1880: 363; Schenkling, 1925: 480 (cat.).

Morion brasiliense: Allen, 1968: 144; Blackwelder, 1945: 33; Jorge-Silva \& Costa, 1983: 1 (larva).

Etimologia: Brasil + -ensis: latim (=formador de adjetivos gentílicos). O nome indica que os exemplares utilizados na descrição original foram coletados em território brasileiro.

Diagnose: escapo glabro, clípeo com dois dentes na margem anterior, pronoto sem cerdas na margem anterior; superfície ventral do tórax com poucas cerdas, presentes apenas no processo prosternal e mesosterno; élitros com úmero arredondado e 
interestria 6 não costiforme próximo à base; asas membranosas reduzidas; pernas anteriores com tíbia levemente angulosa na altura do limpador de antenas e tarsômeros 1-3 dos machos portando ventralmente 2 fileiras de cerdas escamiformes; metatrocânter com tamanho próximo à metade do comprimento do fêmur, ápice fino, sendo encurvado para fora nos machos.

\section{REDESCRIĊ̃̃O:}

Aspecto geral (fig. 01c e 02c): comprimento variando de $13-22 \mathrm{~mm}$.

Antena (fig. 04b): escapo glabro.

Cabeça (fig. 06c): sulcos frontais profundos indo até a margem posterior dos olhos; clípeo com dois dentes na margem anterior; margem anterior quase reta na região mediana.

Mandíbula direita (fig. 10c e 12c): robusta, largura um pouco maior que a metade do comprimento; região molar curta com dois dentes robustos e arredondados. Relação da distância lobo posterior - base da região molar próximo a 1,5.

Mandíbula esquerda (fig. 14c e 16c): região apical com ângulo externo mais dilatado nos machos.

Tórax (fig. 02c, 21c e 22c): bastante convexo; margem anterior quase reta e cerdas ausentes; relação largura/comprimento do pronoto menor que 1,35; linha média moderadamente acentuada e fóveas basais acentuadas; relação do tamanho fóvea/comprimento do pronoto menor que 0,25. Prosterno com apenas duas cerdas próximo à base do processo prosternal e fortemente projetado para baixo. Mesosterno curto, com duas cerdas entre as coxas. Metasterno glabro, encurtado, com largura próximo ao dobro do comprimento; metepisterno também encurtado, com margem anterior de tamanho aproximado à margem posterior.

Perna Anterior (fig. 24c, 25c, 27b e 28c): fêmur com cerdas esparsas, sendo uma na superfície externa próximo ao ápice; superfície interna lisa com algumas estrias e glabra próximo à base. Tíbia levemente angulada na altura do limpador de antenas; projeção externa com o ápice afilado e espinho interno apical bastante pronunciado para dentro; superfície externa não estriada. Distância entre a base da tíbia e o esporão do limpador de antenas menor do que à distância deste e o ápice da tíbia. Diferença de tamanho entre o tarsômeros 3 e 4, apenas nos machos, maior do que entre os demais 
tarsômeros que são progressivamente menores do primeiro ao terceiro; tarsômero $1 \mathrm{com}$ dente apical pronunciado na margem interna apenas nas fêmeas; tarsômeros 1-3 com cerdas ventrais escamiformes apenas nos machos.

Perna mediana (fig. 29c e 31c): tíbia levemente encurvada para dentro, gradualmente alargada da base para o ápice.

Perna posterior (fig. 33c e 35c): trocânter subtriangular com o tamanho próximo à metade do comprimento do fêmur, ápice afilado, sendo encurvado para fora nos machos. Fêmur com cerdas esparsas e não há uma cerda próximo ao ápice na superfície externa, margem interna com projeção bastante acentuada na região mediana, mais evidente nos machos; relação comprimento/ largura da região mediana igual ou superior a 3. Fileira ventral mais curta da tíbia com aproximadamente 4 cerdas; cerdas ventrais esparsas próximo ao ápice da tíbia.

Asa Membranosa (fig. 38c): reduzida, sendo a relação comprimento do corpo/ comprimento da asa de aproximadamente 6,6; alongada, com relação comprimento/largura da asa de aproximadamente 0,24 , sendo um pouco mais larga no terço basal; mais esclerotizada na margem externa e no ápice e célula oblonga ausente.

Élitros (fig. 39c): borda bem definida termina anteriormente ao ápice; úmero reduzido e arredondado, mais estreito do que a lateral do élitro; interestira 6 não costiforme no terço anterior; estria seis e sete bastante fracas na região mediana, podendo ocorrer o mesmo com a estria cinco. Estria 5 mais longa do que a terceira, quarta, sexta e sétima, tendo no ápice uma forte pontuação com margem anterior elevada; interestria 6 mais curta do que as demais; apenas a primeira estria chega ao ápice; não há cerdas nos élitros entre a estria 1 e a sutural próximo ao ápice.

Abdome (fig. 22c): ventrito 2 glabro.

Edeago (fig. 44c, 45b e 46b): lobo médio: moderadamente afilado, quarto basal muito mais robusto que o quarto apical, mais afilado do que nas demais espécies; ponta pós orifício mediano bastante longa, levemente encurvada para baixo orifício mediano estende-se até próximo à metade do lobo médio.

Material examinado: BRASIL - Bahia: G. Bondar col., Com. Inst. Ent. Coll., 1M

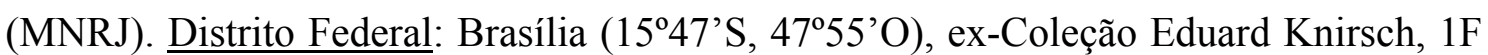
(FMNH). Minas Gerais: Bra de Piquete (ilegível), D. Mareira (ilegível), 1500m, XII.1957, 1M (MNRJ); Manhu Mirim (20²2’S, 4157’O), 30.III.1937, Zellibor-Hauff 
col., Coleção Dr. G H Nick, 1ex. (MZSP); Mar de Espanha (2151'57’'S, 4305'50”O), 1100m, 07.I.1939, Coleção Dr. Nick, 1ex. (MZSP). Espírito Santo: Guarapari (2040’S, 40³0’O), X.1942, 1F (MZSP); Rio Bonito, 600m, 1F (DCMP); Santa Teresa (1955'S, 40³6’O), 15.XI.1967, C. \& T. Elias col., 1F, 1M (DCMP); 19.XI.1964, C. Elias col., 1M (DCMP). São Paulo: Alto da Serra (23o47'S, 46o19’O), IX.1933, R. Spitz col., 1F (MZSP); Bocaina $\left(22^{\circ} 38^{\prime} \mathrm{S}, 4^{\circ} 35^{\prime} \mathrm{O}\right)$, Luederwaldt col., 1M (MZSP); Campo Grande

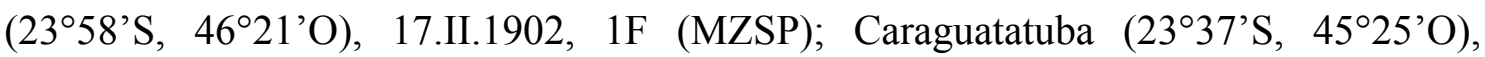
Reserva Florestal - 40m, 22.V.1962, Exp. Dep. Zool. col., 1F (MZSP); VII.1965, Exp. Dep. Zool. col., 1M (MZSP); 02.IV.1962, Martins, Reichardt \& Silva col., 1M (MZSP); 22.V - 01.VI.1962, Exp. Dep. Zool. col., 1M (MZSP); Casa Grande (22²6’S, 4956’O), III.1936, J. Guérin col., 1F (IBSP); I.1936, J. Guérin col., 2F (IBSP);

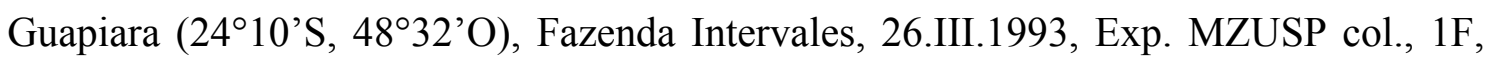

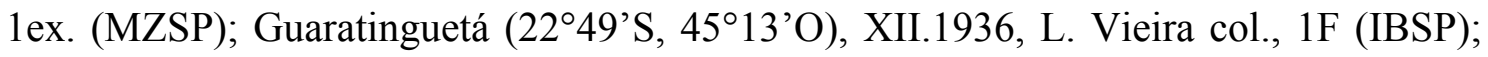

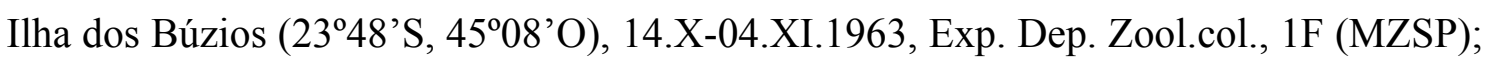

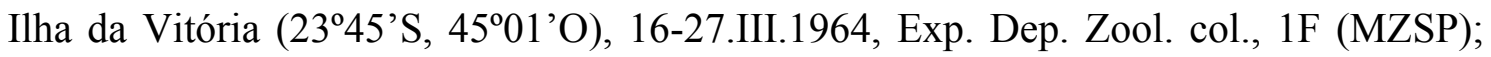

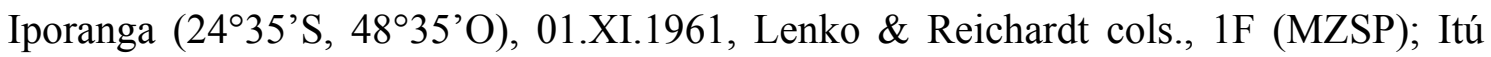

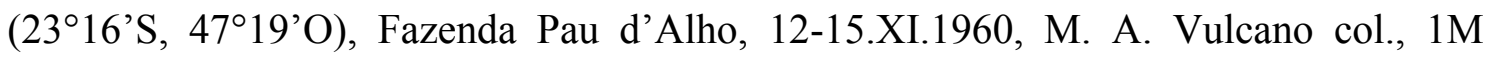
(MZSP); Mongaguá (2406'S, 46³7’O), 05.I.1977, L. R. Fontes \& F.A Berchez col.,

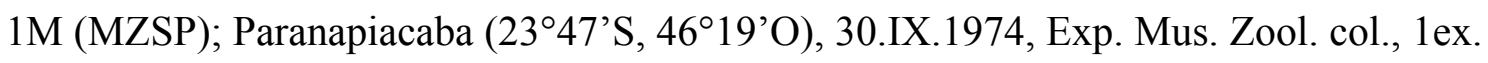
(MZSP); São Bernardo (2342’S, 46³3’O), VIII.1934, J. Guérin col., 1M (IBSP);

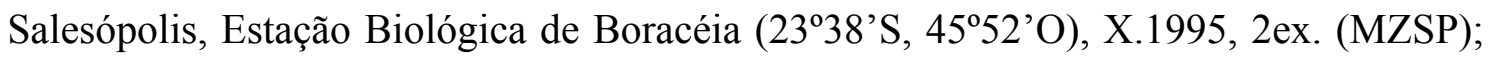
27.03.1994, C. Campaner, S. Ide col., 1F (MZSP); VIII.1961, Oliveira col., 1M

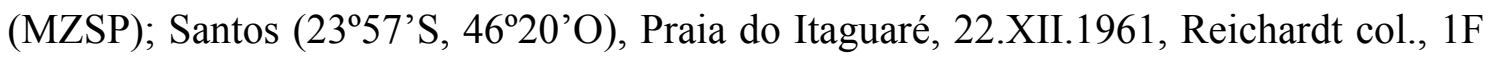

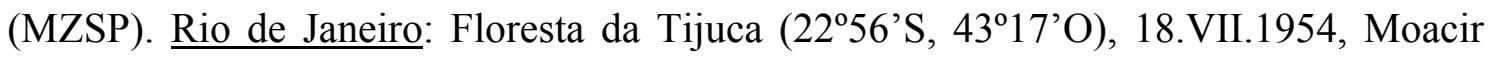
Alvarenga col., Coleção M. Alvarenga, coletado em madeira podre, 1F (MNRJ); Bom Retiro, I-III.1957, Newton Santos col., 1F (MNRJ); Itatiaia (22³0’S, 44³4’O), 1100m,

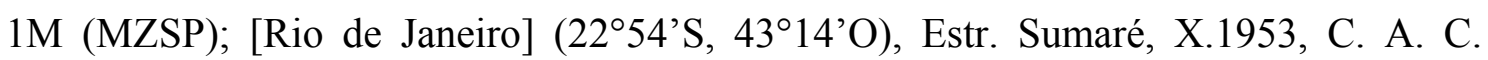
Seabra col., Coleção Campos Seabra, 1F (MNRJ); Serra Macaé (2219’S, 42²0’O), XI.1909, Garbe col., 1F (MZSP). Paraná: Londrina (23¹8’S, 5109’O), I.1934, Coll. J. Guérin, 1M (IBSP); XII.1933, J. Guérin col., 1M (IBSP). Santa Catarina: Mafra (2607’05”S, 4948’06”O), XII.1937, A. Maller col., Coleção Campos Seabra, 1M (MNRJ); Pinhal, XII.1957, A. Maller col., 1F (DCMP); Rio Natal, 400m, 1M (DCMP). Localidade imprecisa: S. Beraido (ilegível), X.1934, 1F (MNRJ). 
Sem localidade: 2M (MNRJ);

\section{Discussão:}

Diferentemente das demais espécies, os exemplares de M. brasiliensis apresentam um dimorfismo sexual externo relativamente mais evidente, pois não se limita apenas às diferenças nos tarsômeros anteriores, mas apresenta uma série de outras modificações entre os sexos relacionadas a mandíbula esquerda, tíbia anterior e metatrocânter. Tanto os machos quanto as fêmeas são braquípteros. Sabe-se que uma série de adaptações e modificações morfológicas seguem junto com a condição braquíptera de algumas espécies de insetos, porém ainda não se sabe ao certo se esses dimorfismos exclusivos de $M$. brasiliensis estão relacionados com a braquipteria, pois não foi possível examinar ambos os sexos da outra espécie com asas membranosas reduzidas, Morion costigera.

Foi encontrado em exemplar fêmea em que o valvífero (genitália) era pouco evidente e glabro, porém este caso foi uma exceção.

Durante o início do estudo dos exemplares de M. brasiliensis no presente trabalho, apareceram dúvidas a respeito da divisão da espécie em duas, porém, ao identificar o sexo dos espécimens, tais diferenças mostraram-se ser, de fato, dimorfismo sexual.

Foi visto também que os espécimens de $M$. brasiliensis são os mais fáceis de diferenciar das demais espécies, principalmente devido à forma mais oval do élitro. $\mathrm{O}$ encurtamento do metasterno e a redução do úmero são características secundárias devido ao braquipterismo. Também foi observado que o lobo médio do edeago é mais afilado do que nas demais espécies.

No trabalho de Allen (1968) é dito que as estrias elitrais 5 à 7 das fêmeas são obliteradas na região mediana, porém nos exemplares estudados essas estrias se mostraram apenas mais fracas e tal característica foi encontrada em ambos os sexos.

No mesmo trabalho, Allen, por examinar apenas 4 espécimes, registrou somente coleta de M. brasiliensis para os estados de São Paulo e Santa Catarina. Só havia informação de data para o espécime de Santa Catarina, coletado em dezembro. No presente trabalho, 48 espécimes foram examinados e a distribuição geográfica foi ampliada para os estados da Bahia, Distrito Federal, Rio de Janeiro, Espírito Santo, Minas Gerais e Paraná, ocorrendo em todos os meses do ano. 


\section{Morion cordata Chaudoir, 1837}

Morion aequatorium Reiche, 1842: 377; Chaudoir, 1880: 353 (sin. de M. georgiae); Blackwelder, 1944: 33 (sin.) (cat.); Allen, 1968: 149 (sin.).

Morion aequatorius: Schenkling, 1925: 480 (sin. de M. georgiae) (cat.).

Morion cordatus Chaudoir, 1837: 437; Chaudoir, 1854: 327; Chevrolat, 1841: pls. 6465; Chaudoir, 1880: 353 (sin. de M. georgiae); Schenkling, 1925: 480 (sinônimo de M. georgiae) (cat.); Allen, 1968: 148; Thompson, 1977: 159 (larva); JorgeSilva \& Costa, 1983: 2 (larva); Davidson, 1990: 216 (distr. geográfica).

Morion cordatum: Blackwelder, 1944: 33 (sin.).

Morion elongatus Chevrolat, 1841: pls. 64-65 (sin. de M. cordatus).

Etimologia: cordatus: latim (= forma de coração).

Diagnose: clípeo com quatro dentes na margem anterior, pronoto com cerdas na margem anterior; superfície ventral do tórax com muitas cerdas, principalmente no prosterno, mesosterno e margens anterior e posterior do metasterno; élitros com interestria 6 não costiforme próximo à base; pernas anteriores dos machos com tarsômeros 2 e 3 portando 2 fileiras de cerdas escamiformes ventralmente; metatrocânter mais curto que a metade do comprimento do metafêmur.

\section{REDESCRIĊ̃̃O:}

Aspecto geral (fig. 01d e 02d): Comprimento variando de 12 - $21 \mathrm{~mm}$.

Antena: escapo com 1 cerda na margem externa.

Cabeça (fig. 06d): Sulcos frontais profundos saindo da linha fronto-clipeal indo até a margem posterior dos olhos. Clípeo com quatro dentes na margem anterior.

Mandíbula direita (fig. 10d e 12d): Robusta, largura um pouco maior que a metade do comprimento; região molar curta com dois dentes robustos e arredondados. Relação da distância lobo posterior - base da região molar próximo a 1 .

Mandíbula esquerda (fig. 14d e 16d): região apical semelhante nos machos e fêmeas. 
Tórax (fig. 02d, 21d e 22d): margem anterior invaginando-se na região mediana e cerdas presentes; relação largura/comprimento do pronoto menor que 1,35; linha média acentuada e fóveas basais bastante acentuadas; relação do tamanho fóvea/comprimento do pronoto maior que 0,25 . Prosterno projetado para baixo com cerdas esparsas; maior concentração próximo às margens das pró-coxas. Mesosterno curto, com cerdas. Metasterno com algumas cerdas esparsas, exceto na região mediana; metepisterno estreito e longo, sendo mais largo anteriormente.

Perna anterior (fig. 24d, 25d e 28d): Fêmur com cerdas esparsas, sendo uma na superfície externa próximo ao ápice; superfície interna lisa com uma cerda próximo à base. Tíbia não angulosa, com margem externa quase reta que se estende no ápice formando uma projeção bastante pronunciada com o ápice arredondado; superfície externa não estriada. Distância entre a base da tíbia e o esporão do limpador de antenas maior ou igual à distância deste e o ápice da tíbia. Tarsômeros progressivamente menores do primeiro ao quarto; tarsômero 1 com dente apical na margem interna em ambos os sexos; tarsômeros 2 e 3 com cerdas ventrais escamiformes apenas nos machos.

Perna mediana (fig. 29d e 31d): Tíbia levemente encurvada para dentro, gradualmente alargada da base para o ápice.

Perna posterior (fig. 33d e 35d): trocânter subtriangular com margem externa arredondada com formação de uma ponta no ápice interno; comprimento inferior à metade do comprimento do fêmur. Fêmur com cerdas esparsas e uma cerda próximo ao ápice na superfície externa, margem interna sem projeção acentuada, relação comprimento/ largura da região mediana igual ou superior a 3. Fileira ventral mais curta da tíbia com aproximadamente 2 cerdas; não há cerdas ventrais esparsas próximo ao ápice da tíbia.

Asa Membranosa (fig. 38d): desenvolvida com tamanho de aproximadamente 0,8 do comprimento do habitus; relação comprimento/largura da asa de aproximadamente 2,6; relação comprimento do ramo mp-cua/comprimento da nervura $\mathrm{MP} 1+2$ de aproximadamente 2,35. Célula oblonga completa.

Élitros (fig. 39d): borda bem definida até o ápice; úmero tão largo quanto a lateral do élitro; interestria 6 não costiforme no terço anterior; estria sete perfeitamente visível e une-se com as terceira, quarta, quinta e sexta, seguindo até próximo ao ápice; apenas a 
primeira estria chega ao ápice; 1 à 3 cerdas em cada élitro entre a estria 1 e a sutura próximo ao ápice.

Abdome (fig. 22d): ventrito 2 com duas cerdas na região mediana.

Edeago (fig. 44d e 45c): lobo médio: quarto basal mais robusto que o quarto apical; ponta pós orifício mediano muito curta, levemente encurvada para baixo; orifício mediano estende-se até próximo ao quarto anterior.

Material examinado: ESTADOS UNIDOS - $\underline{\text { Alabama: }}$ Walker Co., Jasper (3349'52”N, 87¹6’39”O), 02.VIII.1970, 1F (FMNH). MÉXICO - Coleção Karl Brancsik - Ex Coleção Eduard Knirsch, 1M (recebido dissecado), 1ex. (FMNH); Primavera logs., 14.II.1946, 1F (LACM). San Luis Potosi: Valles (215ํN, 9901'O),

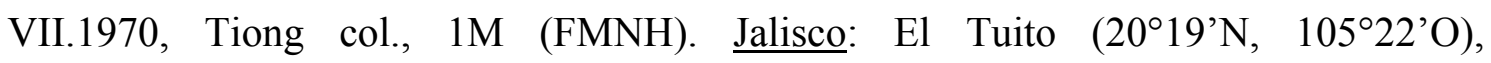
14.VII.1993, Morris, Huether, Wappes cols., armadilha luminosa, 1F (recebido dissecado) (EMEC); Estação Biológica Chamela (19³0’N, 10503’O), 13-23.X.1986, J. A. Chemsak col., coletado na luz, 1F (EMEC). Veracruz - Llave: Cerro Gordo (2040’N, 98¹9’O), ca. 3000 ft alt., 03.VII.1941, C. H. Seevers col., 1F (FMNH); Córdoba (1853’N, 9656’O), 20.VII.1936, C.H. Seevers col., 1M (recebido dissecado) (FMNH); 21.VII.1936, C.H. Seevers col., 1M (recebido dissecado) (FMNH); El Fortin (18 $54^{\prime}$ N, 9700’O), 3000' el., 12.VII.1941, H. S. Dybas col., 1F (FMNH); La Playa Escondida 16km N. Sontecomapan (18³0’N, 9501'O), 02-09.VIII.1980, L. G. Bezark \& C Y Kitayama col., armadilha de luz UV, 1ex. (EMEC); Peñuela, 11.VII.1941, C. H. Seevers col., 1F (FMNH). Chiapas: La Libertad [mais de uma localidade com o mesmo nome], 24.VI.1985, DanHeffern col., 1M (recebido dissecado) (EMEC). REPÚBLICA DOMINICANA - Altagracia: Punta Cana (18³0'16”N, 68²2’37’O), 26.VII.2002, K. Will col., armadilha de luz UV, 1M (EMEC). GUATEMALA - Escuintla: El Zapote (14'23'N, 9052'O); Zapote, elev. 2400 ft., 10.VII.1948, R. D. Mitchell col., coletado debaixo de tronco, 2F (um recebido com genitália dissecada) (FMNH). HONDURAS -

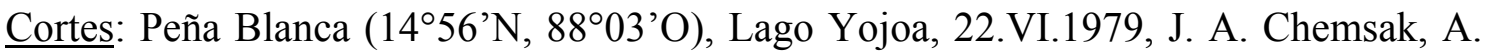
\& M. Michelbacher W. W. Middlekauff cols., 1M (EMEC). NICARÁGUA - Granada: Vulcão Mambuchu [Vulcão Mombacho ?] ( $\left.11^{\circ} 55^{\prime} \mathrm{N}, 85^{\circ} 57^{\prime} \mathrm{O}\right), 1700 \mathrm{~m}, 01-03 . \mathrm{III} .2000$, C. Marshall col., 2F (EMEC). COSTA RICA - La Fuente, 1200m, XII.1931, A. Alforo, 1M (MZSP). PANAMÁ - Zona do Canal, 06-11.V.1981, H. J. Harlan col., armadilha de luz UV) 1M, 1F (FMNH); mesma localidade, Ilha Barro Colorado (0909'49'N, 
7950'16”O), 24.VI.1964, R. W. \& W. Taylor col., 1M (MZSP); VII.1969, 1ex. (FMNH); 28.VII.1938, E. C. Williams, Jr. col., 1F (FMNH); 24-31.X.1969, B. Malkin col., 1M (FMNH); 23.VII.1936, Dr. O. Park col., 1F (FMNH). Panamá: La Correra [Chorrera] (0852’49’N, 7947’O), 22-24.V.1944, R. Arnett col., ex-Coleção Ross Arnett Jr., 1F (FMNH). COLÔMBIA - Cundinamarca: Puerto Salgar (05²8’12”N, 74³9’27’O), 31.VII.1938, Henry Dybas col., 1F (FMNH). VENEZUELA - Las Trincheras [mais de uma localidade com o mesmo nome], VI.1922, L. R. Reynolds col. Coleção F. Psota, 1M (FMNH); Paraiso [mais de uma localidade com o mesmo nome], VI.1922, L. R. Reynolds col., Coleção F. Psota, 1F (FMNH); 24.V.1922, L. R. Reynolds col., Coleção F. Psota, 1ex. (FMNH); Valle del rio Borburata, 200m, 18.III.1960, M. Gelbes col., 1F (MZSP). Zulia: Kasmera Pezila [Kasmera] (0957'09”N, 7245'03”O), 12.IV.1963, P. J. Salinas col., 1M (MZSP). Distrito Federal: Caracas (10³0’N, 6655’O), VII.1943, R. Lichy col., Coleção Dr. G. H. Nick $^{(1)}$, 2exs. (MZSP); 1938, G. Vivas-B. col., ex-Coleção Ross Arnett Jr., 1M (recebido dissecado) (FMNH); Caracas Valley, 22.IV.1973, L. R. Reynolds col., Coleção F. Psota), 2F (FMNH); 04.V.1922, L. R. Reynolds col., Coleção F. Psota, 1M (recebido dissecado) (FMNH). Miranda: Los Ch[o]rros (10³0’N, 6650’O), V.1922, L. R. Reynolds col., Coleção F. Psota, 1F (FMNH). Monagas: 140km NE Barracas (08 $51^{\circ}$ N, 62 00 ’O), Cano Mariusa, Orinoco Delta, 09.VIII.1958, Arnold Menke col.,

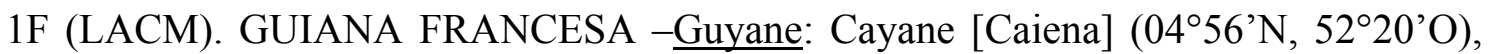
Karl Brancsik Colln. Ex Eduard Knirsch, 1ex. (FMNH).BRASIL - Amazonas: Benjamin Constant (04²2’28’S, 7001'47’O), 18-28.IX.1962, K. Lenko col., 3F (MZSP); II.1941, Parko col., 1M (MNRJ); II.1942, A. Parko col., 1F(MNRJ); mesmo município, Rio Javary - alto Amazonas, II.1942, Coleção Dirings, 2ex. (MZSP); Rio Javary, I.1960, Coleção Dirings, 1ex. (MZSP); IX.1963, Coleção Dirings, 1ex. (MZSP); X.1962, Coleção Dirings, 1ex. (MZSP); XI.1963, Coleção Dirings, 1ex. (MZSP); Itacoatiara (03º3’S, 58²6’O), IX.1964, Coleção Dirings, 2ex. (MZSP); XI.1963, Coleção Dirings, 1ex. (MZSP); Manaos [Manaus], IV.1935, Coleção Dr. G H Nick São Paulo, 1ex.(MZSP); Manaus (0306’48’S, 6001'31”O), 11.IV.1941, Parko col., 1M (MNRJ); 20.I.1956, Elias e Roppa col., 1M (MNRJ); mesmo município, 1. Km. 134, 1F (INPA); Remate de Males (04²1'55’S, 70¹1’35”O), Rio Javary - alt. Amazonas, II.1942, Coleção Dirings, 1ex. (MZSP); Rio Preto da Eva (0241'53”S, 6002’55’O), próx. Boca, 13-15.IV.1967, Exp. Perm. Amaz., 1F (MZSP); Tapuruquara

${ }^{(1)}$ A Coleção Dr. Nick foi incorporada à coleção Dirings. Posteriormente esta coleção (a qual a Coleção Nick já 
(0²4'S, 6502'O), Rio Negro, 25-27.XI.1962, J. Bechyné col., 1M, 1F (MZSP). Pará: Acará $\left(04^{\circ} 55^{\prime} \mathrm{S}, 5^{\circ} 33^{\prime} \mathrm{O}\right)$, Ilha do Combu, 01.X.1989, R. B. Neto col., 1M, 1ex. (MPEG); Altamira, $\left(03^{\circ} 12^{\prime} \mathrm{S}, 52^{\circ} 12^{\prime} \mathrm{O}\right)$, Rio Xingu, III.1964, Coleção Dirings, 1 ex. (MZSP); Carajás (0257’S, 5152’O), Est. Manganês, 24.IV.1983, M. F. Torres col., 1F (MPEG); Melgaço Caxiuanã (014’'S, 5044’O), Base Física, 17.X.1991, J. Dias col., $1 \mathrm{M}$ (MPEG); Mocajuba (02³5’S, 49³0’O), Mangabeira, V.1953, Orlando Rego col., Coleção Campos Seabra, 1F (MNRJ); Óbidos (0155'S, 55³1'O), II.1939, Coll. J Guérin, 1ex. (IBSP); mesmo município, Colônia Rio Branco, XI.1952, P. A. Telles col., Coleção Campos Seabra, 1F (MNRJ); Serra Norte, Manganês, 24.VI.1985, R. B. Neto col., 1M (MPEG); mesma localidade, Pojuca, 11.IX.1985, W. França col., 1F (MPEG); mesma localidade, Serraria, 15.VI.1985, R. Bittencourt col., coleta noturna, 1M (MPEG); Tucuruí (0342’S, 4942’O), Rio Tocantins/Chiqueirinho, 02.IV.1984, F. F. Ramos col., 1M (MPEG); mesmo município, Rio Tocantins/Margem direita Chiqueirinho, 03.IV.1984, F. F. Ramos col., 1M (MPEG). Maranhão: Imperatriz (05³2’S, 47²9’O), 16.VII.1974, Exc. Depto. Zool., 1M (DCMP). Ceará: Carquejo (035'ㅅ, 4044’O), XI.1960, Coleção Dirings, 1ex. (MZSP); IX.1961, Coleção Dirings, 1ex. (MZSP). Mato Grosso: Barra do Tapirapé, 20.VII-15.VIII.1962, B. Malkin col., 1F (FMNH); Cárceres (1604’S, 57²1'O), 28.XI.1984, C. Elias col., 1F (DCMP); Nova Lacerda, Serra (14²8'38'S, 59³3'30”O), 27.IV.2006, J. A. Rafael \& F. F. Xavier Filho cols., Coleta manual (rede entomológica), 1F (INPA). Rondônia: F. P. da Beira [Forte Príncipe da Beira] $\left(12^{\circ} 25^{\prime}\right.$ S, $64^{\circ} 25^{\prime}$ O), 07.XI.1961, F. M. Oliveira

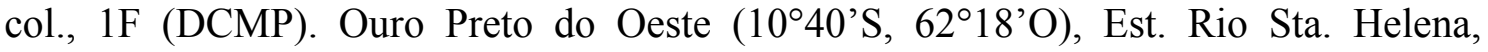
20.III.1985, M. F. Torres col., 1F (MPEG); mesmo município, 20.VIII.1986, F. F. Ramos col., 1F (MPEG); mesmo município, Res. do INPA, 23.VIII.1986, F. F. Ramos col., 1F (MPEG). Acre: Iquiri, VIII.1951, 2F (MZSP). Goiás: Serra da Mesa - Rio Tocantinzinho $\left(14^{\circ} 15^{\prime} \mathrm{S}, 48^{\circ} \mathrm{O}\right)$, XII.1995, C. A. Caetano col., 1F (MNRJ); Anápolis

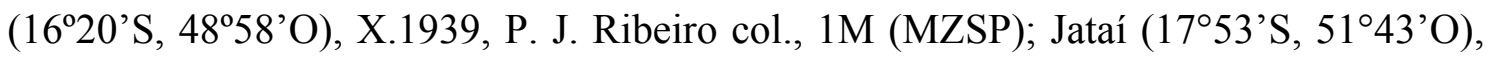
I.1955, 1M (MZSP); Leopoldo Bulhões (16³7'S, 4846’O), XII.1933, Spitz col., 3M, 1F (MZSP); Minaçú (1351'37’S, 48²3’31’O), Serra da Mesa, 19-30.XI.1996, A. Bonaldo col., 1F (MCNZ); Rib. Vãozinho, 12.II.1962, J. Bechyné col., 1M (MZSP).

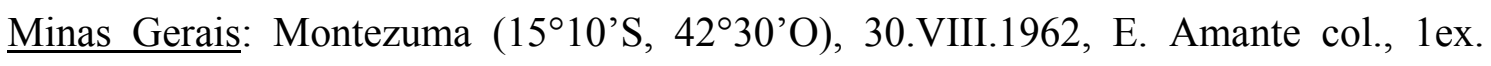
(IBSP); 29.VIII.1962, 1ex. (MZSP); Pouso Alegre (22 13 'S, 4556'O), 24-25.VI.1965, Vulcano - Pereira col., 1F (MZSP); Teófilo Otoni (1751'S, 41³0’O), 08.X.1967, Exp. 
Dep. Zool., 1M (MZSP). Mato Grosso do Sul: Maracaju (2138'S, 5509’O), III.1937, Sannon Lane col., 1M (MZSP); Três Lagoas (2048'S, 51 $\left.{ }^{\circ} 43^{\prime} \mathrm{O}\right)$, Fazenda Retiro de Telhas, 15-30.V.1964, Exp. Dep. Zool., 1F (MZSP). Espírito Santo: Collatina (19³2’S, 40³7'O), X.1936, M. Rosa col., 1M, 1F (MNRJ); Conceição da Barra (18³5'S, 39²5’O), 11.X.1969, C. T. \& C. Elias col., 1F (DCMP); Corrego Itá [Barra do São Francisco] (1845’S, 4052’O), X.1954, W. Zikan col., 3M, 1F (MNRJ), 1M (MZSP); XI.1956, W. Zikan col., 3F, 5M (MNRJ); 1M (MZSP); Linhares (19²5’S, 4004’O), III.1954, P. A. Teles col., Coleção Campos Seabra, 2F (MNRJ); 20.XI.1971, A. C. Domingos col., 1M (DCMP); 24-31.VII.1972, C. Elias col., 1ex. (DCMP); mesmo município, Parque Sooretama (1903’22’S, 4008’50”O), X.1953, P. A. Teles col., Coleção Campos Seabra, 1M (MNRJ); V.1953, P. A. Tefas col., Coleção Alvarenga, 1ex. (DCMP); XI.1967, F. M. Oliveira col., 1M (MZSP), 1ex. (DCMP); Santa Teresa (1955’S, 40³6’O), 07.XII.1964, C. Elias col., 2F (DCMP); 13.I.1966, C. T. \& C. Elias col., 2F (DCMP); 10.VI.1964, C. Elias col., 2F (DCMP); II.1964, C. \& T. Elias col., 1F (DCMP); 1F (MZSP); 19.X.1964, C. Elias col., 1M (DCMP); 04.II.1966, C. Tadeu Elias col., 1M (DCMP). São Paulo: Aparecida do Norte (22 $\left.52^{\circ} \mathrm{S}, 45^{\circ} 14^{\prime} \mathrm{O}\right)$, Forster col., 1F (MZSP); Ilha dos Búzios (2348'S, 4508’O), 16.X-4.XI.1963, Exp. Dep. Zool.

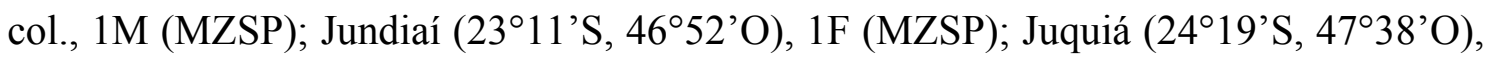
Fazenda Poço Grande, 27.IV.1948, F. Lane col., 1F (MZSP); Leme (22¹2'S, 47²4'O), III.1935, Coll. D. B., 1M, 1F (IBSP); Peruíbe (24¹9’S, 4700’O), 07.I.1938, Coll. Zellibor-Hauff, 1F (MNRJ); mesmo município, Rio Barra do Una, 17.XII.1980, Exp.

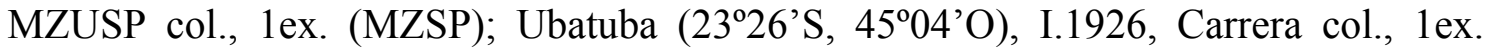

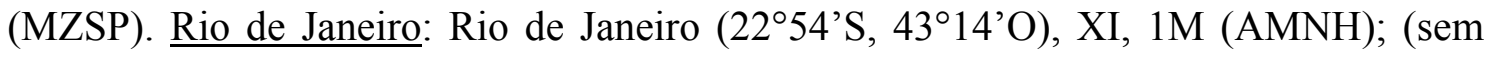
data) 1F (AMNH); São Fidélis (2139’S, 4144’O), VIII.1956, O. Alvarenga col., Coleção Campos Seabra, 2ex. (MNRJ); [Seropédica] (2244’50”S, 4343’01”O), Estr. Rio-São Paulo km 47, 20.X.1943, O. Braga col., 1M (MNRJ). Paraná: Antonina,

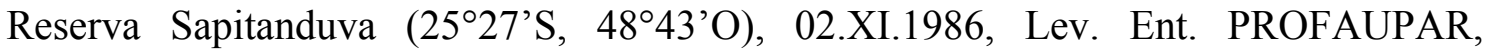
armadilha luminosa, 1F (DCMP); Fênix, Reserva Est. - ITCF (235'ㅇ, 51 $\left.57^{\prime} \mathrm{O}\right)$, 03.XI.1986, Lev. Ent. PROFAUPAR, armadilha luminosa, 2M (DCMP); Guarapuava, Est. Águas Sta. Clara $\left(25^{\circ} 23^{\prime} \mathrm{S}, 5^{\circ} 27^{\prime} \mathrm{O}\right)$, 20.XI.1987, Lev. Ent. PROFAUPAR, armadilha luminosa, 1F (DCMP); Heimtal (23ำ $\left.15^{\prime} \mathrm{S}, 5^{\circ} 09^{\prime} \mathrm{O}\right)$, Norte Paraná, X.1935, Coleção Dirings, 1ex. (MZSP); Jundiaí do Sul, Fazenda Monte Verde $\left(23^{\circ} 27^{\prime} \mathrm{S}\right.$, 50¹7’O), 30.XI.1986, Lev. Ent. PROFAUPAR, armadilha luminosa, 1M (DCMP); 
Londrina (2318’S, 5109'O), XII.1933, Coll. J Guérin, 1ex. (IBSP); Monjolinho (2421'S, 5052'O), I.1943, Coleção F. Justus Jor, 2ex. (DCMP); Ponta Grossa (2505'S, 5009'O), XII.1938, C. A. Camargo col., 1F (MZSP); Prudentópolis (25o12'S, 50o57'O), J. Izaak, Zawiercie col., Karl Brancsik Colln. Ex Eduard Knirsch, 1M (FMNH); Rio Negro, I.1929, 1M (IBSP); Telêmaco Borba, Res. Samuel Klabin

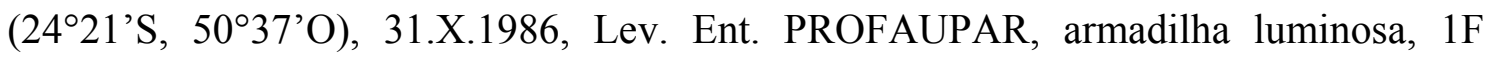
(DCMP); Terra Boa, Sítio Indaiá (2345’50”S, 52²3’32”O), 08.V.2006, J. A. Rafael \& F.F. Xavier Filho cols., coleta manual (rede entomológica), 1M (INPA). Santa Catarina:

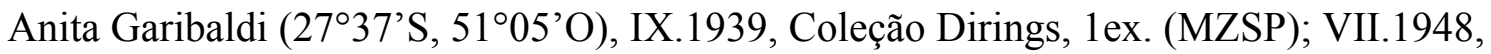
Coleção Dirings, 1ex. (MZSP); Blumenau (2656’S, 4903’O), XII.1927, Luderwaldt col., 1F (MZSP); Corupá (26²6’S, 49¹4’O), XI.1937, A. Maller col., Coleção Campos Seabra, 1M, 1F, 1ex. (MNRJ); II.1957, A. Maller col., Coleção Campos Seabra, 1F (MNRJ); II.1952, A. Maller col., Coleção Campos Seabra, 1M (MNRJ); I.1938, A. Maller col., Coleção Campos Seabra, 2M (MNRJ); III.1968, Coleção Campos Seabra, 1F (MNRJ); II.1965, 1ex. (MNRJ); II.1938, A. Maller col., Coleção Campos Seabra, 1ex. (MNRJ); I.1953, A. Maller col., Coleção Campos Seabra, 1ex. (MNRJ); I.1954, A. Maller col., Coleção Alvarenga, 1F (DCMP); Hansa [Corupá], 16.VIII.1910, 3M (MZSP); VII.1910, 1M, 6F (um dessecado), 1ex. (MZSP); 1ex. (MZSP); Jaraguá do Sul (26²9'S, 4904'O), XI.1937, A. Maller col., Coleção Campos Seabra, 1ex. (MNRJ); Mafra (2607’05”S, 4948’06”O), XII.1937, A. Maller col., Coleção Campos Seabra,

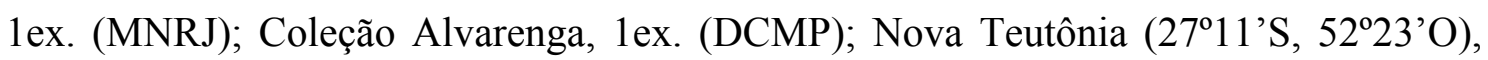
V.1935, Fritz Plaumann col. 1F (DCMP); XII.1933, Fritz Plaumann col., 1M (DCMP); II.1939, Coll. J Guérin, 1M (IBSP); XI.1939, Coll. J. Guérin, 1ex. (IBSP); XI.1932, Coll. J. Guérin, 1M (IBSP); 26.VIII.1939, Fritz Plaumann col., Coleção Dr. G. H. Nick, 1ex. (MZSP); VIII.1944, Fritz Plaumann col., Coleção Dr. G. H. Nick, 1ex. (MZSP); 14.X.1939, Coleção Dr. G. H. Nick, 2ex. (MZSP); 01.X.1943, Coleção Dr. G. H. Nick, 3exs. (MZSP); 25.VII.1951, Coleção Dr. G. H. Nick, 1ex. (MZSP); (sem data), Coleção Dr. G. H. Nick, 1ex. (MZSP); V.1941, Coleção Dirings, 2F, 1M (MZSP); 11.X.1965, 1ex. (AMNH); São Francisco (26¹4’S, 48³9’O), Nov. Jan. 1948 [XI.1948 - I.1949], A. Maller col., 1ex. (AMNH); Timbó (2650'S, 49¹8'O), V.1956, Coleção Dirings, 1M (MZSP); IV.1956, Coleção Dirings, 2 exs. (MZSP); II.1962, Coleção Dirings, 2 exs. (MZSP); XI.1956, Coleção Dirings, 5exs. (MZSP); XII.1962, Coleção Dirings, 1M

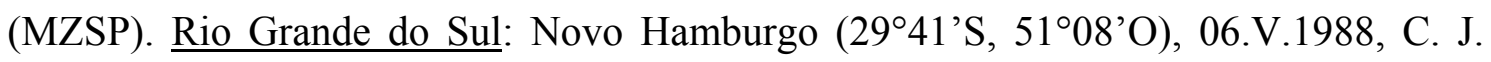


Becker col., 1F, 1M (MCNZ); Porto Alegre (3002’S, 51²12’O), IV.1928, 1F (MZSP); X.1929, Coleção Dirings, 1ex. (MZSP); Tapes, Fazenda São Miguel (30²8'58.2”S, 51²2’20.8”O), 14.V.2003, Equipe Probio col., coleta manual, 1F (MCNZ). EQUADOR -Napo: Napo, Yasuni Scientific Station 200m (0040'16.7’'S, 77²4'01.8'O), 14.IV.1998, K. Will col., armadilha de luz uv/mv, 1M (EMEC). Pastaza: Ashuara (0244’S, 77²4’O), Rio Macuma, 10km from Rio Morona, 300m., 07-16.VII.1971, B. Malkin col., 1M, (FMNH); Cusuimi, Rio Cusuimi 150km SE Puyo, 300m., 1823.VII.1971, B. Malkin col., 2M, 1ex. (FMNH). PERU - Loreto: Estiron (03²2’06”S, 7204'40”O), Rio Ampiyacu, 13.XI - 09.XII.1961, B. Malkin col., 3F (FMNH); 15-

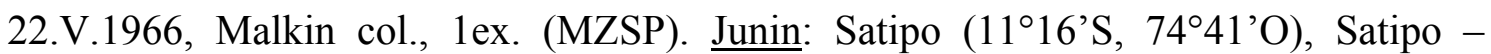
Huanoayo, 17.XII.1937, Paprzycki col., Coleção Dr. G. H. Nick, 1ex. (MZSP); 16.XII.1937, Paprzycki col., 1M, 1ex. (MNRJ); I.1944, Papryzicki col., 1M (LACM). BOLÍVIA -Beni: Vila indígena Chacobo no rio Benicito $\left(12^{\circ} 20^{\prime} \mathrm{S}, 66^{\circ} \mathrm{O}\right)$, 28 31.VII.1960, 2F (recebidos com genitália dissecada) (FMNH); 31.VII-02.VIII.1960, 2M (recebidos com genitália dissecada) (FMNH). Santa Cruz: Província de Ichilo,

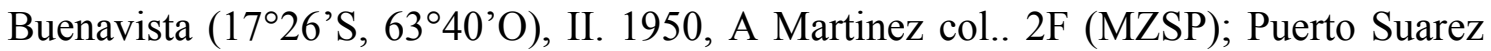
(1857’S, 5748’O), XII.1949, R. Zischka col., Coleção Dr. G H Nick - São Paulo, 2ex. (MZSP); San Antonio de Parapeti (2001'S, 6313'O), 3-5.VII.1964, B. Malkin col., 1M (MZSP). Cochabamba: Cochabamba (17²3’S, 6609’O), XII.1949, L. Peña col., Coleção Dr. G. H. Nick - São Paulo, 1ex. (MZSP). PARAGUAI - Departamento Central: Assunción (2516’S, 5740’O), VIII.1949, Coleção Dr. G. H. Nick, 1ex. (MZSP). ARGENTINA 3exs. (MZSP). Puerto Esperanza (2601'S, 54³9’O), II.1961, A. Martinez col., 1F (MZSP).

\section{Discussão:}

Essa espécie apresenta dimorfismo sexual. Os tarsômeros 2-3 da perna anterior dos machos possuem duas fileiras de cerdas escamiformes na superfície ventral. Essa espécie pode ser confundida com M. monilicornis, porém a grande concentração de cerdas no prosterno e região anterior do metasterno em $M$. cordata permite facilmente distingui-las. 
Ao dissecar a genitália de um exemplar fêmea, foi encontrado um ovo. Este ovo é arredondado, levemente alongado, não muito esclerotizado e ocupa aproximadamente a metade de todo o volume do abdômen do besouro. Foi visto que há rugosidade por toda a parede do ovo, porém isto pode ser devido ao ressecamento deste, já que o espécimen estava seco. Havia somente um ovo.

Freqüentemente foi visto rugosidade próximo ao ápice do fêmur posterior, porém não foi visto em todos os exemplares.

A distribuição geográfica de $M$. cordata é bastante ampla, ocorrendo desde o sul do Brasil até o norte do México; um espécime com rótudo do leste dos Estados unidos foi encontrado, porém, como já foram feitas muitas coletas nessa região e este é o único exemplar da espécie para essa localidade, pode-se supor que houve algum erro de rotulagem ou este espécime foi transportado junto com madeira de exportação.

Há registro de espécimens coletados em todos os meses do ano e a informação de espécimes coletados com armadilha luminosa, armadilha de luz negra e rede entomológica.

\section{Morion costigera Darlington, 1934}

Morion costigerus Darlington, 1934: 90; Allen, 1968: 150.

Morion costigerum: Blackwelder, 1944: 33 (cat.).

Etimologia: costa, ae: latim (=costela). Na descrição original Darlington não justifica a escolha do epíteto específico, porém, provavelmente, refere-se à sétima interestria elitral que é fortemente costiforme no terço anterior, característica usada e discutida no trabalho de 1934.

Diagnose: clípeo com quatro dentes na margem anterior; pronoto sem cerdas na margem anterior; superfície ventral do tórax com cerdas no protórax, mesotórax e na porção anterior do metatórax; élitro com estria 7 fortemente costiforme no terço basal; pernas anteriores com tarsômeros 2 e 3 portando 2 fileiras de cerdas escamiformes ventralmente; metatrocânter mais longo que a metade do comprimento do metafêmur. 


\section{REDESCRIČ̃̃O:}

Nota: devido a falta de material, a redescrição de $M$. costigera foi baseada na descrição original de Darlington, 1934, na redescrição de Allen, 1968 (que também baseou-se na original), no trabalho de Darlington de 1941 e em fotos do holótipo conseguidas na base de dados online dos tipos do Museum of Comparative Zoology (Universidade de Harvard) (http://mcz-28168.oeb.harvard.edu/mcz/index.htm). Os dados da distribuição geográfica foram tirados de Allen (1968), onde 5 espécimens foram examinados.

Aspecto geral (fig. 01i): Comprimento variando de 17 - $22 \mathrm{~mm}$.

Antena: escapo com 1 cerda na margem externa.

Cabeça: Sulcos frontais profundos saindo da linha fronte-clipeal indo até a margem posterior dos olhos. Clípeo com quatro dentes na margem anterior. "olhos proeminentes, menos abruptos que em georgiae".

Tórax: pronoto subquadrangular; convexo; ângulos anteriores levemente arredondados e convergentes e os posteriores pequenos, levemente divergentes; margem anterior invaginando-se na região mediana e cerdas ausentes; margem anterior maior do que a posterior; relação largura/comprimento do pronoto menor que 1,35; linha média acentuada e fóveas basais bastante acentuadas; relação do tamanho fóvea/comprimento do pronoto maior que 0,25 . Prosterno projetado para baixo com cerdas esparsas; maior concentração próximo às margens das pró-coxas. Mesosterno curto com cerdas entre as coxas. Metasterno com cerdas (mais densas próximo à margem anterior), encurtado; metepisterno também encurtado.

Perna anterior: Tíbia não angulosa, com margem externa quase reta que estende-se no ápice formando uma projeção bastante pronunciada com o ápice arredondado. Distância entre a base da tíbia e o esporão tibial maior ou igual à distância entre este e o ápice da tíbia. Tarsômeros 2 e 3 com cerdas ventrais escamiformes apenas nos machos.

Perna mediana: Tíbia lateralmente achatada, fortemente arqueada para dentro, gradualmente alargada da base para o ápice, porém, a partir do terço apical torna-se muito mais larga.

Perna posterior: trocânter subtriangular, longo, com comprimento superior à metade do comprimento do fêmur, afilando-se em direção ao ápice. Fêmur com 
margens quase paralelas e cerdas esparsas, margem interna sem projeção ou apenas fracamente acentuada, relação comprimento/ largura da região mediana igual ou superior a 3 .

Asa Membranosa : reduzida (Darlington, 1941).

Élitros: estrias moderadamente acentuadas, sendo as últimas não pontuadas; intervalos ligeiramente convexos, exceto o sétimo que se inclina basalmente, de modo que a quinta estria está no fundo de uma depressão em forma de $\mathrm{V}$; terceira interestria com uma pontuação única próximo à segunda estria, pouco antes do terço apical; úmero mais estreito do que a lateral do élitro; sétimo intervalo costiforme no terço anterior, mais acentuado do que em $M$. simplex.

Abdome: ventrito 2 com duas cerdas na região mediana; ventrito 6 com 1 cerda de cada lado, próximo ao ápice, podendo ter uma segunda cerda em um dos lados.

\section{Discussão:}

Segundo Allen (1968), os exemplares de M. costigerus parecem grandes exemplares de M. monilicornis alongados, apresentando todos os caracteres desta espécie, a não ser pelo sétimo intervalo elitral que é fortemente costiforme em $M$. costigerus (mais acentuada do que em M. simplex). Analisando a foto do holótipo de $M$. costigerus, nota-se outra catacterística que difere M. costigera de M. monilicornis: o úmero de $M$. costigera é mais estreito e arredondado do que o das demais espécies (exceto M. brasiliensis), provavelmente por ser uma característica secundária devido à condição braquíptera.

Como nenhum exemplar foi examinado no presente trabalho, não pôde-se saber se a asa membranosa de $M$. costigera apresenta o mesmo tipo de braquipteria do que a apresentada em M. brasiliensis.

Há registro de espécimens coletados nos meses: janeiro, março, agosto, outubro e dezembro, ocorrendo apenas na Jamaica. 


\section{Morion cycloma Chaudoir, 1854}

Morion cyclomus Chaudoir, 1854: 328; Chaudoir, 1880: 357; Schenkling, 1925: 480 (cat.); Blackwelder, 1944: 33 (cat.); Allen, 1968: 144.

Etimologia: cyclomus: latim (=circular).

Diagnose: clípeo com dois dentes na margem anterior, pronoto sem cerdas na margem anterior; superfície ventral do tórax com poucas cerdas, sendo apenas no processo prosternal e mesosterno, às vezes apresenta uma ou duas cerdas no processo intercoxal posterior e/ou posterior do metasterno; élitros com interestria 6 não costiforme próximo à base; pernas anteriores dos machos com tarsômeros 1-3 portando 2 fileiras de cerdas escamiformes ventralmente; metatrocânter mais curto que a metade do comprimento do metafêmur.

\section{REDESCRIÇ̃̃O:}

Aspecto geral (fig. 01e e 03a) : comprimento variando de 13 à $22 \mathrm{~mm}$.

Antena (fig. 04c): escapo com 1 cerda na margem externa.

Cabeça (fig. 07a): sulcos frontais profundos indo até a base dos olhos; raramente apenas até a margem anterior destes. Clípeo com dois dentes na margem anterior; margem anterior escavada na região mediana.

Mandíbula direita (fig. 11a, 13a): robusta, largura um pouco maior que a metade do comprimento; região molar curta com dois dentes robustos e arredondados. Relação da distância lobo posterior - base da região molar próximo a 1.

Mandíbula esquerda (fig. 15a, 17a): região apical semelhante nos machos e fêmeas.

Tórax (fig. 03a e 23a): margem anterior invaginando-se na região mediana e cerdas ausentes; relação largura/comprimento do pronoto maior que 1,35; linha média moderadamente acentuada e fóveas basais acentuadas; relação do tamanho fóvea/comprimento do pronoto maior que 0,25 . Prosterno com cerdas apenas na base do processo prosternal e projetado para baixo. Mesosterno curto, com cerdas. Metasterno 
com apenas algumas cerdas próximo ao processo intercoxal anterior e/ou posterior; metepisterno estreito e longo, sendo mais largo anteriormente.

Perna anterior (fig. 24e, 26a e 27a): Fêmur com cerdas esparsas, sendo uma na superfície externa próximo ao ápice; superfície interna lisa com uma ou mais cerdas próximo à base. Tíbia não angulosa, com margem externa quase reta que se estende no ápice formando uma projeção bastante pronunciada com o ápice arredondado; superfície externa não estriada. Distância entre a base da tíbia e o esporão do limpador de antenas maior ou igual à distância deste e o ápice da tíbia. Diferença de tamanho entre os tarsômeros 3 e 4 , apenas nos machos, maior do que entre os demais tarsômeros que são progressivamente menores do primeiro ao terceiro; tarsômero 1 com dente apical pronunciado na margem interna apenas nas fêmeas; tarsômeros 1-3 com cerdas ventrais escamiformes apenas nos machos.

Perna mediana (fig. 30a e 32a): Tíbia levemente encurvada para dentro, gradualmente alargada da base para o ápice.

Perna posterior (fig. 34a e 36a): trocânter subtriangular com margem externa arredondada, estreitado no ápice interno; comprimento inferior à metade do comprimento do fêmur. Fêmur com cerdas esparsas, com uma cerda próximo ao ápice na superfície externa, margem interna sem projeção ou apenas fracamente acentuada, relação comprimento/ largura da região mediana igual ou superior a 3. Fileira ventral mais curta da tíbia com aproximadamente 4 cerdas; cerdas ventrais esparsas próximo ao ápice da tíbia.

Asa Membranosa (fig. 38e): desenvolvida com comprimento de aproximadamente 0,8 do comprimento do habitus; relação comprimento/largura da asa de aproximadamente 2,6; ramo mp-cua incompleto formando uma área mais esclerotizada próximo à base alar. Célula oblonga incompleta.

Élitros (fig. 40a): borda bem definida até o ápice; úmero tão largo quanto a lateral do élitro; interestria 6 não costiforme no terço anterior; estria sete perfeitamente visível e une-se com as terceira, quarta, quinta e sexta, seguindo até próximo ao ápice; apenas a primeira estria chega ao ápice; não há cerdas em cada élitro entre a estria 1 e a sutura próximo ao ápice.

Abdome (fig. 23a): ventrito 2 glabro. 
Edeago (fig. 44e, 45d e 46c): lobo médio: quarto basal levemente mais robusto que o quarto apical; ponta pós orifício mediano fortemente encurvada para baixo; orifício mediano estende-se até próximo ao terço anterior.

Material examinado: ESTADOS UNIDOS - Indiana: 30.X.1934, Coleção Dr G H Nick, 2 exs. (MZSP). Alabama: Coosa Co., 12mi SW Sylacanga (3300’23”N, 86¹2’06”O), 18.IX.1959, H R Steeves Jr. col., Coleção H.G. Steeves Gen. Coleop., coletado embaixo de serragem, 1F (FMNH). PANAMÁ - Zona do Canal, Ilha Barro Colorado (0909'49”N, 7950'16”O), 24-31.X.1969, B. Malkin col., 1M (FMNH). BRASIL Roraima: Balawa-U / Posto Yano (0148'S, 63²7'O), 17.V.1995, L. Aquino col., 1 ex. (INPA). Pará: Mocajuba (02³5’S, 49³0’O), Mangabeira, X.1952, O. Rego col., Coleção Campos Seabra, 1 ex. (MNRJ); Serra Norte, Pojuca, 27.X.1983, Márcio Zanute

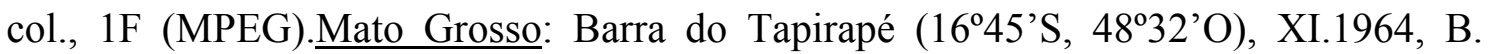

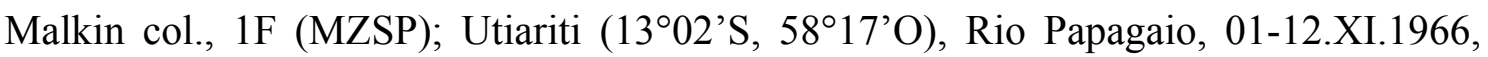
Lenko \& Pereira col., 2F (MZSP). Rondônia: Forte Príncipe da Beira (12²5'S, 6425'O), 19.XI-03.XII.1967, G. R. Kloss col., 1M (MZSP); Ji-Paraná (1050’S, 6158’O), Fazenda Sinveiro, 24.VIII.1986, W. França col., 1F (MPEG); Ouro Preto do

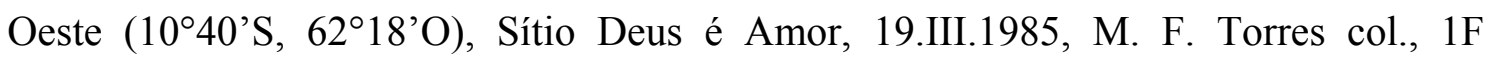
(MPEG); Porto Velho (0846’S, 6354'O), 15.IV.1996, A. Bonaldo col., 2F (MCNZ); mesmo município, Guaporé, XI.1954, F. Pereira, Wermer, Dente, M. Alvarenga cols., 1F (MNRJ). Acre: Rio Branco (08 $\left.{ }^{\circ} 14^{\prime} \mathrm{S}, 7^{\circ} 3^{\circ} 13^{\prime} \mathrm{O}\right)$, 11.X.1952, M. Alvarenga col., 2F (MNRJ); mesmo município, Catuaba, 09.IV.1996, A. Bonaldo col., 1M (MCNZ).

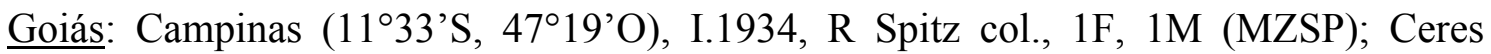
(15¹7’S, 49³5’O), III.1971, O. Roppa col., 1M (MZSP); Jaraguá (1545’S, 49²0’O), VII.1934, 1M (MZSP); Leopoldo Bulhões (16³7’S, 4846’O), XII.1933, Spitz col., 2M, 1F (MZSP); Paraíso, 08-14.II.1962, J. Bechyné col., 1F (MZSP); Rio Verde (17¹3'S, 51³3'O), 19-28.XI.1966, G. R. Kloss col., 3F, 2M (MZSP); ColeçãoDr. Nick, 1 ex. (MZSP); Viannópolis (16² $\left.45^{\prime} \mathrm{S}, 4^{\circ} 32^{\prime} \mathrm{O}\right)$, III.1950, R. Spitz col., 1F (MZSP); XI.1931, R Spitz col., 2M (MZSP); XII.1931, R Spitz col., 2M (MZSP). Minas Gerais: Araxá (19³5’S, 4655’O), 07.X.1965, C. Elias col., 1F (DCMP); Ibiá (19²9’S, 46³2'O), 20.X.1965, C. T. \& C. Elias col., 1M (DCMP); Rio Verde, 400m,

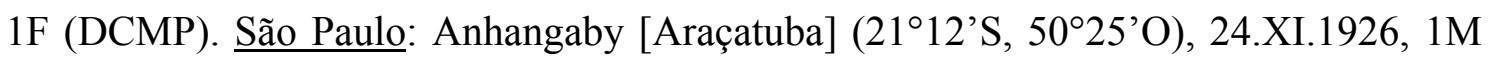

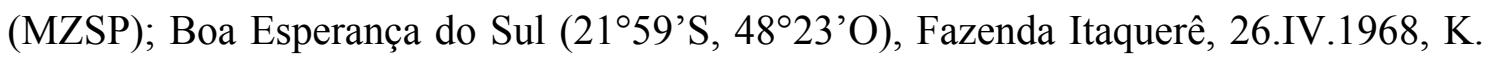


Lenko col., 1F (MZSP); Descalvado (Escaramuça) (24³9’'S, 4840’O), 25.IV.1944, Schubart col., 1M (MZSP); Franca (20³3'S, 47²4'O), XI.1902, O. Dreher col., 1F

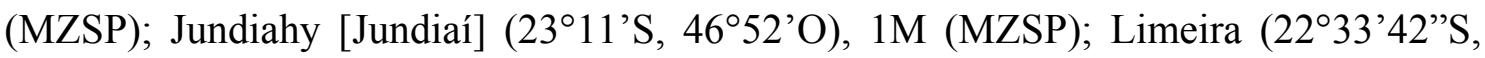
47²4’10”O), 09.IV.1947, Rosetto col., 1M (MZSP), Marília (22¹3’S, 4956’O), I.1948, 1ex., 1F (MZSP); Nova Europa (2146’'S, 48³3’O), Fazenda Itaquerê, 29.IV.1968, K. Lenko col., 1M (MZSP); Presidente Epitácio ( $\left.21^{\circ} 46^{`} \mathrm{~S}, 5^{\circ} 06^{`} \mathrm{O}\right)$, Pto. Albano - Rio Paraná, X.1954, J. Lane col., Coleção J. Lane, 1F (MZSP); Regente Feijó

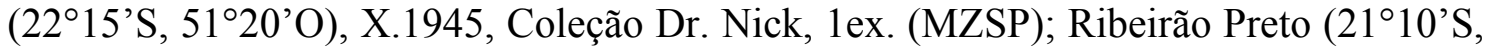
47²8’'O), Faculdade de Medicina, X.1954, Barreto col., Coleção M. P. Barreto, 1969,

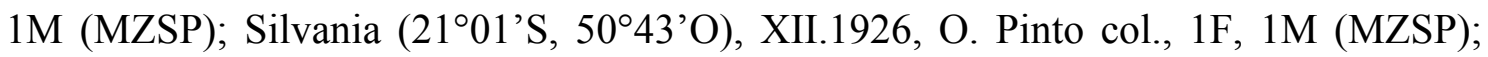
Tabatinga (21 ${ }^{\circ} 43^{\prime}$ S, $\left.48^{\circ} 41^{\prime} \mathrm{O}\right)$, Fazenda Itaquerê, 27.VIII.1965, Lenko \& Pereira col.,

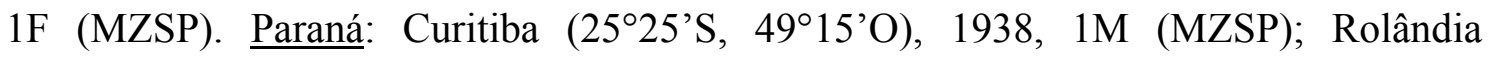
(2318’S, 51²2’O), 21.IX.1946, Roosen Runge col., Coleção Dr.Nick, 2exs. (MZSP); mesmo município, Caviuna, 27.IX.1946, Roosen Runge col., Coleção Dr. Nick, 1ex. (MZSP). Rio Grande do Sul: São Borja (28³9’S, 56º), 12.XII.1975, C. J. Backer col., 1M (MCNZ). EQUADOR -Pastaza: Cusuimi, Rio Cusuimi 150km SE Puyo, 300m, 1823.VII.1971, B. Malkin col. 1M (FMNH); 15-31.V.1971, B. Malkin col., 1M (FMNH).

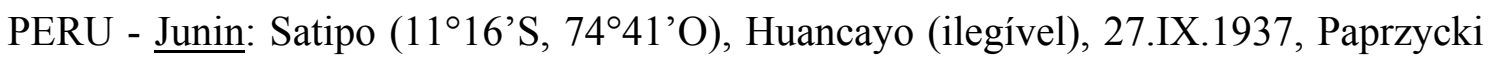
col., 1ex. (MZSP). PARAGUAI - 1F (FMNH). Alto Paraguay: Emboscada, X.1954, Coleção Dr. G. H. Nick, 1ex. (MZSP). Departamento Central: Assuncion (2516'S, 57²0’O), VII.1949, Dr. Nick col., Coleção Dr.G. H. Nick, 1ex. (MZSP). ARGENTINA

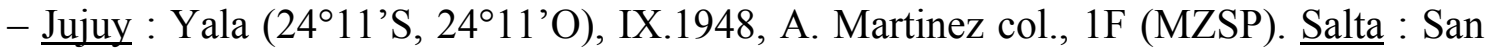
Martin (2534'S, 66 $\left.14^{\prime} \mathrm{O}\right)$, Pocitos, I.1962, A. Martinez col., 1F (MZSP). Misiones : Loreto (2719'S, 55³2’O), IX.1955, Coleção Dr. G. H. Nick, 1 ex. (MZSP); San Pedro

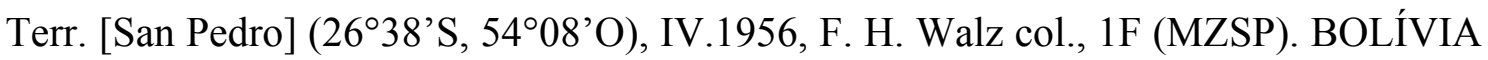
- Puerto Juarez, VI.1950, R. Zischka col., Coleção Dr. G. H. Nick, 1 ex. (MZSP). Beni : Chacobo Indian Village on Rio Benicito (12²0'S, 66 O), 01-10.VII.1960, B. Malkin col., 1F (FMNH). Santa Cruz : Província Ichilo, Buenavista (17²7’'S, 6340’O), I.1950, A. Martinez col., 1M (MZSP).

Sem localidade: 1F (FMNH); 2 ex. (IBSP); II.1937, 1F (MZSP)

Localidades não encontradas: Angatuba (ilegível), 2M (MNRJ); Ghremeir (ilegível), 1F (MNRJ); Salta [mais de uma localidade com o mesmo nome], 1M (FMNH). 


\section{Discussão:}

Apresenta dimorfismo sexual; os machos têm duas fileiras de cerdas escamiformes na superfície ventral dos tarsômeros anteriores 1-3 e a diferença de tamanho entre os tarsômeros 3 e 4 é maior do que a diferença entre os demais tarsômeros.

Os exemplares de M. cycloma são muito parecidos com os exemplares de $M$. boliviensis. Para diferenciar as duas espécies é preciso verificar se o metasterno é glabro (M. boliviensis) e se a ponta pós orifício mediano do lobo médio é fortemente encurvada para baixo (M. cycloma).

Segundo Allen (1968), apenas exemplares de M. boliviensis possuem sulcos frontais curtos, chegando apenas até a altura da margem anterior dos olhos; porém, foi visto alguns exemplares de M. cycloma com esta característica; apesar disso, esses exemplares apresentavam os caracteres de M. cycloma, inclusive metasterno glabro e ponta pós orifício mediano do lobo médio fortemente encurvada para baixo.

Alguns exemplares apresentam rugosidade próximo ao ápice do fêmur posterior.

A distribuição geográfica é bastante ampla; essa espécie ocorre na América Central (Panamá) e por grande parte da América do Sul (Brasil, Equador, Peru, Paraguai, Argentina e Bolívia). Há um registro para o leste dos Estados Unidos, porém, assim como discutido para M. cordata, provavelmente ocorreu algum erro de rotulagem ou o espécime foi transportado pelo homem. Há registro de espécimens coletados em todos os meses do ano.

\section{Morion lafertii Guérin, 1844}

Morion lafertii Guérin, 1844a: 254.

Morion lafertei; Chaudoir, 1880: 362; Schenkling, 1925: 481 (cat.); Blackwelder, 1944: 33 (cat.); Allen, 1968: 151.

Morion spiniger Chaudoir, 1854: 331; Chaudoir, 1880: 362 (sin.); Schenkling, 1925: 481 (sin.) (cat.); Blackwelder, 1944: 33 (sin.) (cat.); Allen, 1968: 151 (sin.).

Etimologia: na descrição original o autor não justifica a escolha do epíteto. De acordo com a regra de nomenclatura zoológica, a terminação -i deve ser usada no final 
do nome de uma pessoa a qual o autor da espécie quer homenagear, portanto, provavelmente Guérin escolheu o epíteto "lafertii" para homenagear Laferté (um antigo especialista da família Carabidae). De acordo com as regras de nomenclatura, o epíteto específico para homenagear Laferté deveria ser lafertei, porém o autor decidiu usar lafertii na descrição original. Segundo o código Internacional de Nomenclatura Zoológica, o nome da espécie deve ser corrigido somente quando há um erro não proposital, ou seja, um erro de impressão ou de datilografia (Artigo 32.5). Este tipo de erro foi descartado, uma vez que no mesmo trabalho de 1844, Guérin descreve outras espécies homenagiando M.A. Niéto e cria o epíteto nietii ao invés de nietoi.

Diagnose: clípeo com quatro dentes na margem anterior; pronoto sem cerdas na margem anterior; superfície ventral do tórax glabra; prosterno fortemente projetado para baixo; élitros com interestria 6 levemente costiforme próximo à base; pernas anteriores dos machos com tarsômeros sem cerdas escamiformes na superfície ventral; metatrocânter mais longo que a metade do comprimento do metafêmur.

\section{REDESCRIĊ̃̃O:}

Aspecto geral (fig. 01f e 03b): Comprimento variando de 16 - 24 mm.

Antena: escapo com 1 cerda na margem externa.

Cabeça (fig. 07b): Sulcos frontais profundos saindo da linha fronte-clipeal indo até a margem posterior dos olhos. Clípeo com quatro dentes na margem anterior.

Mandíbula direita (fig. 11b e 13b): Robusta, largura um pouco maior que a metade do comprimento; região molar curta com dois dentes robustos e arredondados. Relação da distância lobo posterior - base da região molar próximo a 1.

Mandíbula esquerda (fig. 15b e 17b): região apical semelhante nos machos e fêmeas.

Tórax (fig. 03b, 21f e 23b): margem anterior quase reta e cerdas ausentes; relação largura/comprimento do pronoto menor que 1,35; linha média fracamente acentuada e fóveas basais acentuadas; relação do tamanho fóvea/comprimento do pronoto menor que 0,25 . Prosterno glabro, fortemente projetado para baixo. Mesosterno curto e glabro. Metasterno glabro; metepisterno estreito e longo, sendo mais largo anteriormente. 
Perna anterior (fig. 24f, 26b, 27c e 28f): Fêmur com cerdas esparsas, sendo ausente na superfície externa próximo ao ápice; superfície interna com algumas estrias e glabra próximo à base. Tíbia não angulosa, com margem externa quase reta que se estende no ápice formando uma projeção bastante pronunciada com o ápice arredondado; superfície externa bastante estriada. Distância entre a base da tíbia e o esporão tibial maior ou igual à distância deste até o ápice da tíbia. Tarso pentâmero com tarsômeros progressivamente menores do primeiro ao quarto; tarsômero 1 com dente apical bastante pronunciado na margem interna em ambos os sexos; tarsômeros sem cerdas ventrais escamiformes.

Perna mediana (fig. 30b e 32b): Tíbia lateralmente achatada, fortemente arqueada para dentro, gradualmente alargada da base para o ápice, porém, a partir do terço apical torna-se muito mais larga.

Perna posterior (fig. 34b e 36b): trocânter subtriangular, longo, com comprimento superior à metade do comprimento do fêmur, afilando-se em direção ao ápice. Fêmur com margens quase paralelas e cerdas esparsas, há uma cerda próximo ao ápice na superfície externa, margem interna sem projeção ou apenas fracamente acentuada, relação comprimento/ largura da região mediana igual ou superior a 3. Fileira ventral mais curta da tíbia com aproximadamente 4 cerdas; não há cerdas ventrais esparsas próximo ao ápice da tíbia.

Asa Membranosa (fig. 38f): desenvolvida com comprimento de aproximadamente 0,8 do comprimento do habitus; relação comprimento/largura da asa de aproximadamente 2,6; ramo mp-cua incompleto, não atingindo o quarto basal da nervura MP1+2. Célula oblonga incompleta.

Élitros (fig. 40b): borda bem definida termina anteriormente ao ápice; úmero tão largo quanto a lateral do élitro; estria sete apenas fortemente marcada na base e no ápice e une-se com as terceira, quarta, quinta e sexta, seguindo até próximo ao ápice; interestira 6 levemente costiforme no terço anterior; apenas a primeira estria chega ao ápice, sendo bastante larga na região subapical; 1 à 3 cerdas em cada élitro entre a estria 1 e a sutura próximo ao ápice.

Abdome (fig. 23b): ventrito 2 raramente com duas cerdas na região mediana.

Edeago (fig. 44f, 45e e 46d): lobo médio: quarto basal mais robusto que o quarto apical; ponta pós orifício mediano curta, levemente encurvada para baixo; orifício mediano estende-se até próximo ao quarto anterior. 


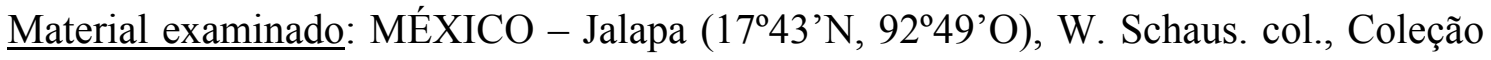

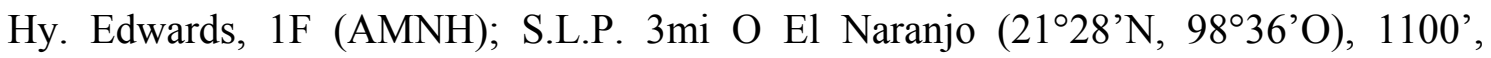
25.VI.1973, A. Newton col., coletado em câmara de lixo de Atta mexicana, 1F, 1M (FMHN); 1000', 25.VI.1973, A. Newton col., coletado em câmara de lixo de Atta mexicana, 1M (FMHN). Tamaulipas: Victoria, 22.V.1952, M. Cazier, W. Gertsch, R. Schrammel col., 1M (AMNH). Jalisco: Estação Chanela, UNAM, 14.IX.1993, Morris, Huether, Wappes col., armadilha de luz UV, 1ex. (EMEC); Ajijic $\left(20^{\circ} 18^{\prime} \mathrm{N}, 103^{\circ} 17^{\prime} \mathrm{O}\right)$, 21.V.1948, J. Hendrichs col., 1F, 2M (AMNH). Aguascalientes: Aguas, 29.VI.1953, D. Rockefeller Mex. Exp 1953 C. \& P. Vaurie col., 1F (AMNH). Hidalgo: 4mi NE Chapul-huacán, 2200 pés, 27.VI.1973, A. Newton col., coletado em câmara de lixo de Atta mexicana, 1F (FMHN). Veracruz-Llave: Dos Amontes Catenivro [ilegível], 05.X.1968, P. Reyes M. Cab. [ilegível], Formigueiro de Atta sp., 1ex.M (MZSP); Fortin (18 $\left.54^{\prime} \mathrm{N}, 9^{\circ} 01^{\prime} \mathrm{O}\right)$, Canyon SO do Rio Metlac, 3200-3400 pés, 13-18.VII.1971, A. Newton col., coletado em câmara de lixo de Atta mexicana, 5exs. (FMHN); 3200 pés, 28.VII.1973, A. Newton col., coletado em câmara de lixo de Atta mexicana, 5F, 5M (FMHN); 4.4mi N Huatusco (19²13'N, 96 $57^{\circ}$ 'O), 02.VIII.1973, A. Newton col., 4200 pés, coletado em câmara de lixo de Atta mexicana, 1F (FMHN). Chiapas: El Chorreodero, 600m, 15.V.1991, J. D. McCarty col., 1ex. (EMEC). EL SALVADOR -

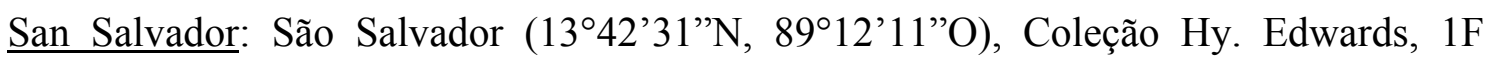
(AMNH); 14.VI.1954, V. Bechyne col., 1M (dissecado) (MZSP).

\section{Discussão:}

Não foi encontrado dimorfismo sexual nesta espécie, nem mesmo nos tarsômeros anteriores.

De um modo geral, Morion lafertii se parece muito com M. simplex, porém, há algumas características externas que facilmente as distinguem, como: a presença de muitas cerdas em quase toda a superfície ventral torácica, a presença de cerdas na margem anterior do pronoto e o forma menos arredondada deste em $M$. simplex, além do metatrocânter de $M$. lafertii ter, geralmente, a margem externa mais arredondada no quarto proximal, indo retilineamente até o ápice, deixando-o mais encaixado no fêmur do que em M. simplex, que muitas vezes apresenta o ápice levemente encurvado para fora. Apesar de a sexta interestria ser costiforme no terço basal de ambas as espécies, é 
mais acentuada em $M$. simplex. Em apenas um exemplar foi encontrada cerdas no esternito 2 e foi observado também que o tamanho do trocânter posterior pode variar, chegando, em alguns exemplares, até próximo do comprimento do fêmur. Duas cerdas foram encontradas no escapo de um exemplar.

Há alguns dados da literatura discordantes daqueles encontrados nesse trabalho, como por exemplo no trabalho de Allen (1968), onde ele afirma que a descrição original de $M$. lafertii é muito boa e válida, diferenciando-a de $M$. brasiliensis, entre outras coisas, por ser composta por exemplares maiores. Porém, no presente trabalho foram encontrados exemplares de $M$. brasiliensis maiores do que certos exemplares de $M$. lafertii, invalidando, deste modo, o caráter usado na comparação das espécies.

Há registro de espécimens coletados apenas nos meses mais quentes: maio, junho, julho, agosto, setembro e outubro, ocorrendo no México e América Central (Costa Rica e El Salvador). Alguns exemplares foram encontrados em câmaras de lixo de Atta mexicana. Há informação de coleta com armadilha de luz negra.

\section{Morion monilicornis (Latreille, 1806)}

Harpalus monilicornis Latreille, 1806: 206; Latreille, 1810: 159 (sin.); Bousquet \& LaRochelle, 1993: 160 (sin. de M. monilicornis)(cat. distr. geográfica).

Morion monilicornis: Dejean, 1825: 430; Chaudoir, 1880: 353 (sin. de M. georgiae); Cockerel, 1913: 300; Schenkling, 1925: 480 (sin. de M. georgiae) (cat.); Allen, 1968: 147; Bousquet \& LaRochelle, 1993: 160 (cat. distr. geográfica).

Morion cayennensis: Dejean, 1821 (cat.); Dejean, 1825 (430) (sin.)

Scarites georgiae Palisot, 1821: 107; Dejean, 1825: 430 (sin.); Bousquet \& LaRochelle, 1993: 160 ( $\sin$. de M. monilicornis) (cat. distr. geográfica)

Morion georgiae: Chaudoir, 1880: 353; Schenkling, 1925: 480 (cat.); Blackwelder, 1945: 33 (cat.); Allen, 1968: 147 (sin.).

Morion monilicorne: Blackwelder, 1945:33 (sin. de M. georgiae).

Etimologia: moníle: latim (=colar) + cornu,us: latim (=corno, chifre). O nome refere-se às antenas moniliformes, ou seja, segmentos antenais em forma de contas, uma das 
poucas características usadas na descrição original do gênero, que inicialmente continha apenas esta espécie.

Diagnose: clípeo com quatro dentes na margem anterior; pronoto com cerdas na margem anterior; superfície ventral com poucas cerdas, sendo que, quando presentes, apenas no processo prosternal e/ou no mesosterno; élitros com interestria 6 não costiforme próximo à base; pernas anteriores dos machos com tarsômeros 1-3 portando 2 fileiras de cerdas escamiformes ventralmente; metatrocânter mais curto que a metade do comprimento do metafêmur.

\section{REDESCRIČÃO:}

Aspecto geral (fig. 01g e 03c): Comprimento variando de 16 - $26 \mathrm{~mm}$.

Antena: escapo com uma cerda na margem externa.

Cabeça (fig. 07c): Sulcos frontais profundos saindo da linha fronte-clipeal indo até a margem posterior dos olhos. Clípeo com quatro dentes na margem anterior.

Mandíbula direita (fig. 11c e 13c): Robusta, largura um pouco maior que a metade do comprimento; região molar curta com dois dentes robustos e arredondados. Relação da distância lobo posterior - base da região molar próximo a 1.

Mandíbula esquerda (fig. 15c e 17c): mais afilada e longa e com ápice mais curvo do que a mandíbula direita, região apical semelhante nos machos e fêmeas.

Tórax (fig. 03c, 21g e 23c): margem anterior envaginando-se na região mediana e cerdas presentes; relação largura/comprimento do pronoto menor que 1,35; linha média acentuada e fóveas basais bastante acentuadas; relação do tamanho fóvea/comprimento do pronoto maior que 0,25. Prosterno quando com cerdas, apenas no processo prosternal, projetado para baixo. Mesosterno curto, podendo ou não apresentar cerdas. Metasterno glabro; metepisterno estreito e longo, sendo mais largo anteriormente.

Perna anterior (fig. 24g, 26c e 28g): Fêmur com cerdas esparsas, sendo uma na superfície externa próximo ao ápice; superfície interna lisa e glabra próximo à base. Tíbia não angulosa, com margem externa quase reta que se estende no ápice formando uma projeção bastante pronunciada com o ápice arredondado; superfície externa não estriada. Distância entre a base da tíbia e o esporão do limpador de antenas maior ou igual à distância deste e o ápice da tíbia. Tarsômeros progressivamente menores do 
primeiro ao quarto; tarsômero 1 com dente apical na margem interna em ambos os sexos; tarsômeros 1-3 com cerdas ventrais escamiformes apenas nos machos.

Perna mediana (fig. 30c e 32c): Tíbia levemente encurvada para dentro, gradualmente alargada da base para o ápice.

Perna posterior (fig. 34c e 36c): trocânter subtriangular com margem externa arredondada com formação de uma ponta no ápice interno; tamanho inferior à metade do comprimento do fêmur. Fêmur com cerdas esparsas, uma cerda próximo ao ápice na superfície externa, margem interna sem projeção acentuada, relação comprimento/ largura da região mediana igual ou superior a 3. Fileira ventral mais curta da tíbia com aproximadamente 2 cerdas; não há cerdas ventrais esparsas próximo ao ápice da tíbia.

Asa Membranosa (fig. 38g): desenvolvida com comprimento de aproximadamente 0,8 do habitus; relação comprimento/largura da asa de aproximadamente 2,6; relação comprimento do ramo mp-cua/comprimento da nervura MP1+2 de aproximadamente 2,35. Célula oblonga completa.

Élitros (fig. 40c): borda bem definida até o ápice; úmero tão largo quanto a lateral do élitro; interestria 6 não costiforme no terço anterior; estria sete perfeitamente visível e une-se com as terceira, quarta, quinta e sexta, seguindo até próximo ao ápice; apenas a primeira estria chega ao ápice; 1 a 3 cerdas em cada élitro entre a estria 1 e a sutural próximo ao ápice.

Abdome (fig. 23c): ventrito 2 com duas cerdas na região mediana.

Edeago (fig. 44c, 45b e 46e): lobo médio: quarto basal mais robusto que o quarto apical; ponta pós orifício mediano muito curta, levemente encurvada para baixo; orifício mediano estende-se até próximo ao quarto anterior.

Material examinado: ESTADOS UNIDOS - ChasPalm col., Bor. Art, 1ex. (AMNH); Collection of Mrs. A T Slosson, 1ex. (AMNH). Missouri: Mc Donald Co.,BoskyDell (36³6’05’N, 94²6’46”O), 21.IX.1909, Mus. Expd. / Gerhard col., 1M (FMNH). Arkansas: ChasPalm col., 1ex. (AMNH). Carolina do Sul: Beaufort Co., Beaufort (32²5’53”N, 8040’12”O), 18.IV.1893, G. D. Bradford col., 1ex. (AMNH);

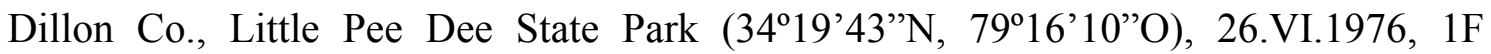
(AMNH); Georgetown Co., 7mN. Georgetown (0451'47’N, 82³1'18’O), 30.V.1978, R M Brattain col. (AMNH); Hobcaw Barony [Nature Center] (3322' N, 79²14'O), 26.V.1996, K. Will col., 1F (EMEC); Pickens Co., Clemson (3440’60”N, 8250’15’O), 
01.VII.1958, R.C. Fox col., armadilha luminosa, 1ex. (FMNH). Texas: 1F (AMNH); Hardin Co., Silsbee (30²0'56”N, 94¹0’40”O), 02.II.1922, 1ex. (FMNH); San Jacinto Co., Oakhurst $\left(30^{\circ} 44^{\prime} 13\right.$ 'N, 95¹8'57”O), 10.V.1952, M Cazier, W Gertsch, R Schrammel cols., 1ex. (AMNH). Georgia: Thomasville (mais de uma cidade com o mesmo nome), W F Fiske col., 2F (MZSP); Clarke Co., Athens (3357'39”N, 83²2’41”O), 21.I.1958, Sandifer, T.A col., Oct. 59 Stihr / N.M. Downie Colln, 1F

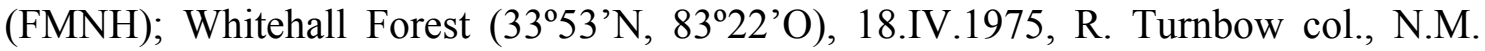
Downie Colln., 1M, 1ex. (FMNH); DeKalb Co., Stone Mountain (3348'29”N, 84¹0'13”O), 10.II.1935, P.W. Fatting, 1F, 1ex. (FMNH); 10.V.1931, 1F (FMNH); Ware Co., Waycross $\left(31^{\circ} 12^{\prime} 48^{\prime \prime} \mathrm{N}, 82^{\circ} 21^{\prime} 15^{\prime} \mathrm{O}\right)$, 11.X.1958, Daniel Pittnut col. (ilegível), N.M. Downie Colln., 1ex. (FMNH); Wheeler Co., Along Atlamha River

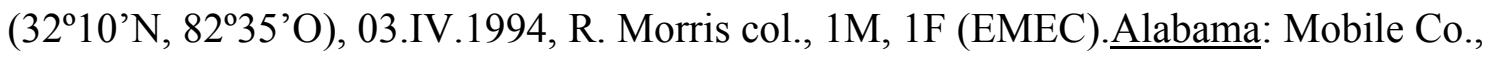
Chunchula $\left(30^{\circ} 55^{\prime} 18^{\prime} \mathrm{N}, \quad 88^{\circ} 12^{\prime} 02^{\prime} \mathrm{O}\right), \quad 19 . X .1915, \quad 1 \mathrm{ex} . \quad(\mathrm{AMNH}) ; \quad$ Mobile

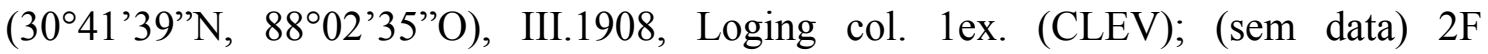

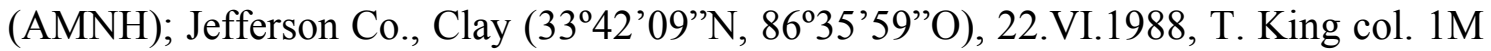
$(\mathrm{FMNH})$; Montgomery Co., Mamie $\left(32^{\circ} 11^{\prime} 11^{\prime \prime} \mathrm{N}, 8^{\circ} 02^{\prime} 26^{\prime \prime} \mathrm{O}\right)$, 08.I.1921, L. B. Woodruff col., 1ex. (AMNH). Mississipi: George Co., $11 \mathrm{mi}$ SW of Lucedale Pascagoula R. $\left(30^{\circ} 48^{\prime} \mathrm{N}, 88^{\circ} 42^{\prime} \mathrm{O}\right)$, 25.V.1995, K. Will \& R. Androw cols. 2M (recebido com genitália dissecada) (EMEC). Flórida: 1 ex. (AMNH); Coll ChasPalm, 2exs. (AMNH); F.M.N.H. Coll. (E Chope Coll), 1ex. (FMNH); Duval Co., Jacksonville $\left(30^{\circ} 19^{\prime} 55^{\prime} \mathrm{N}, 81^{\circ} 39^{\prime} 21^{\prime \prime}\right.$ ), Collection of Mrs. A. T. Slosson, 1ex. (AMNH); South Jacksonville, 19.XII.1920, 2ex. (AMNH); Frankling Co., Eastpoint (30²5'23”N, 81'35'57’O), 29.III.1976, N.H. Downie col., 1F, 1M (FMNH); Highlands Co.,

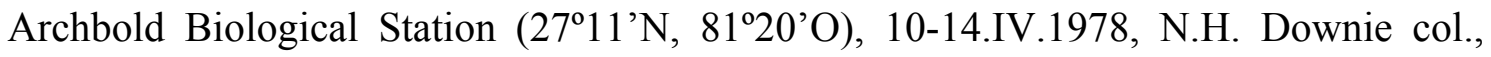
1M, 2F, 1ex. (FMNH); 07.IX.1983, 2M; IV.1956, C.C. Hoff col., rotten Pinus logs., 1ex. (AMNH); Lake Placid, Archbold Biological Statation (2717’34’N, 81²1'47’O), 23.I.1943, M Cazier, W Gertsch, R Schrammel col. 1ex. (AMNH); Highlands Co.,

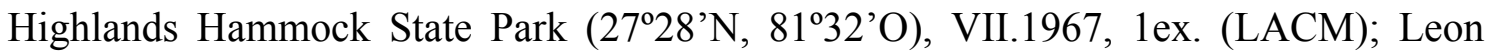

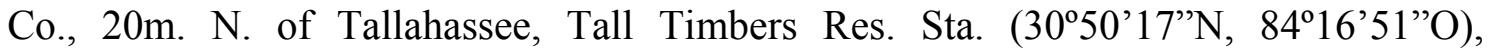
07.IV.1972, N.M. Downie Colln., 1M (FMNH); Liberty Co., Torreya State Park

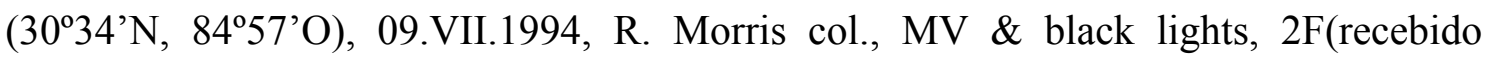
dissecado) (EMEC); Madison Co., I-10 Rest area, III.1993, R. Morris col., 1M (EMEC) (recebido com genitália dissecada); Pinellas Co., Tarpon Springs (2808’45”N, 
8245’25”O), Coleção de Mrs. A T Slosson, 1ex. (AMNH); 21.III.1943, B. Malkin col., CMNH 1960 Borys Malkin Coleoptera colln., 1M, 1ex. (FMNH); Sarasota Co., Sarasota (27²0’10”N, 82³1'51’O), 31.I.1911, W S D col., 1ex. (AMNH); 08.IV.1983, N.H. Downie col., N.M. Downie Colln., 1F (FMNH); Seminole Co., Sanford $\left(28^{\circ} 45^{\prime} 30^{\prime \prime N}\right.$; 81¹7’40”O) 1ex. (LACM); Wakulla Co., Tallahasee (30²6’17’N, 84¹6’51”O), 28.III.1979, R. M. Brattain col. 1ex. (EMEC); Miss. [Missouri ?, Mississipi ?], Mandauo (ilegível), 12.III.1992, 1ex. (AMNH).

\section{Discussão:}

Esta espécie apresenta dimorfismo sexual: os tarsômeros anteriores 1-3 dos machos apresentam cerdas ventrais escamiformes.

M. monilicornis pode ser confundida com $M$. cordata, porém a ausência de grande concentração de cerdas na superfície ventral do tórax, principlamente no prosterno e região anterior do metasterno permite diferenciá-las facilmente. Outra diferença é a distribuição geográfica distinta; M. monilicornis só foi registrada nos Estados Unidos, enquanto $M$. cordata não é registrada para tal país.

Algumas raras variações intraespecíficas foram observadas, como a presença de duas cerdas no prosterno próximo ao processo intercoxal de alguns exemplares, a presença de uma cerda no processo intercoxal anterior do metasterno de um exemplar e a ausência de cerdas na margem anterior do pronoto de outro exemplar.

Há registro de exemplares coletados em todos os meses do ano, exceto julho e novembro; há também informação de espécimes coletados com armadilha de luz negra. Esta espécie ocorre no centro e leste dos Estados Unidos.

\section{Morion simplex Dejean, 1826}

Morion bifemoratus Dejean, 1831: 512 (sin.); Schenkling, 1925: 482 (sin.) (catálogo). Morion bifemoratum: Blackwelder, 1944: 33 (sin.) (cat.); Allen, 1968: 149 (sin.). Morion simplex Dejean, 1826: 481; Dejean \& Boisduval, 1829: 230, t.22, f.7; Guérin, 1844b: prancha 5, figura 7 (ilustração); Chaudoir, 1854: 327; Chaudoir, 1880: 
356; Schenkling, 1925: 482 (cat.); Blackwelder, 1944: 33 (cat.); Allen, 1968: 149;

Davidson, 1990: 216 (distr. geográfica).

Etimologia: simplex: latim (= um só, único). O autor não justifica o uso de tal epíteto específico

Diagnose: clípeo com quatro dentes na margem anterior, porém os dois centrais são pouco distintos; pronoto com cerdas na margem anterior; superfície ventral do tórax com muitas cerdas no prosterno, mesosterno e metasterno; prosterno fortemente projetado para baixo; élitros com interestria 6 costiforme próximo à base; pernas anteriores dos machos com tarsômeros 2 e 3 portando 2 fileiras de cerdas escamiformes ventralmente; metatrocânter mais longo que a metade do comprimento do metafêmur.

\section{REDESCRIÇÃO:}

Aspecto geral (fig. 01h e 03d): Comprimento variando de $16-26 \mathrm{~mm}$.

Antena (fig. 04d): escapo com 1 cerda na margem externa.

Cabeça (fig. 07d): Sulcos frontais pouco profundos saindo da linha fronte-clipeal indo até a margem posterior dos olhos. Clípeo com quatro dentes na margem anterior, porém os dois medianos são pouco distintos, assimétricos e freqüentemente estão fundidos.

Mandíbula direita (fig. 11e 13d): Robusta, largura um pouco maior que a metade do comprimento; região molar curta com dois dentes robustos e arredondados. Relação da distância lobo posterior - base da região molar próximo a 1.

Mandíbula esquerda (fig. 15d e 17d): região apical semelhante nos machos e fêmeas.

Tórax (fig. 03d, 21h e 23d): margem anterior quase reta e cerdas presentes; relação largura/comprimento do pronoto menor que 1,35; linha média moderadamente acentuada e fóveas basais acentuadas; relação do tamanho fóvea/comprimento do pronoto menor que 0,25 . Prosterno com muitas cerdas e fortemente projetado para baixo. Mesosterno curto, com cerdas. Metasterno com muitas cerdas esparsas, com maior concentração próximo às margens das pró-coxas; metepisterno estreito e longo, sendo mais largo anteriormente, sendo mais largo anteriormente. 
Perna anterior (fig. 24h, 26d, 27d e 28h): Fêmur com cerdas esparsas, sendo uma na superfície externa próximo ao ápice; superfície interna com algumas estrias e uma cerda próximo à base; terço basal da margem interna dilatado, formando um pequeno lobo interno. Tíbia não angulosa, com margem externa quase reta que se estende no ápice formando uma projeção bastante pronunciada com o ápice arredondado; superfície externa estriada. Distância entre a base da tíbia e o esporão tibial maior ou igual à distância deste e o ápice da tíbia. Diferença de tamanho entre os tarsômeros 3 e 4, apenas nos machos, maior do que entre os demais tarsômeros que são progressivamente menores do primeiro ao terceiro; tarsômero 1 com dente apical na margem interna em ambos os sexos; tarsômeros 2 e 3 com cerdas ventrais escamiformes apenas nos machos.

Perna mediana (fig. 30d e 32d): Tíbia fortemente arqueada para dentro, gradualmente alargada da base para o ápice, porém, a partir do terço apical torna-se muito mais larga.

Perna posterior (fig. 34d e 36d): trocânter subtriangular, longo, com tamanho superior à metade do comprimento do fêmur, afilando-se em direção ao ápice. Fêmur com margens quase paralelas e cerdas esparsas, há uma cerda próximo ao ápice na superfície externa, margem interna sem projeção ou apenas fracamente acentuada, relação comprimento/ largura da região mediana igual ou superior a 3. Fileira ventral mais curta da tíbia com aproximadamente 4 cerdas; cerdas ventrais esparsas próximo ao ápice da tíbia.

Asa Membranosa (fig. 38h): desenvolvida com comprimento de aproximadamente 0,8 do comprimento do habitus; relação comprimento/largura da asa de aproximadamente 2,6; ramo mp-cua não visível, formando apenas uma área mais eclerotizada próximo à base alar. Célula oblonga completa.

Élitros (fig. 40d): borda bem definida termina anteriormente ao ápice; úmero tão largo quanto a lateral do élitro; interestria 6 costiforme no terço anterior; sexta estria junta-se com as sétima, quinta, quarta e terceira; estria sete perfeitamente visível seguindo até próximo ao ápice; nenhuma estria chega ao ápice; 2 à 4 cerdas em cada élitro entre a estria 1 e a sutural próximo ao ápice.

Abdome (fig. 23d): ventrito 2 com aproximadamente 6 cerdas na região mediana. 
Edeago (fig. 44h, 45g e 46f): lobo médio: quarto apical mais robusto que o quarto basal; ponta pós orifício mediano curta, levemente encurvada para baixo; orifício mediano estende-se até próximo ao terço anterior.

Material examinado: COSTA RICA - Puntarenas: Península de Osla, El Tigre $\left(08^{\circ} 33^{\prime}\right.$ N, $\left.83^{\circ} 22^{\prime} \mathrm{O}\right), 25$. VI.2001, W. Moore col., coletado em câmara de lixo de Atta sp, 1ex. (EMEC). TRINIDAD E TOBAGO - Baía Balandra, 19.III.1922, L. R. Reynolds col., Coleção F. Psota, 1F (FMNH). Saint George Co.: Blanchisseuse $\left(10^{\circ} 47^{\prime} \mathrm{N}, 61^{\circ} 18^{\prime} \mathrm{O}\right)$, Pass, Rodovia Blanchisseuse, 18.II.1964, J. G. Rozen \& P. Wygodzinsky col., 1F (AMHN). COLÔMBIA - Antioquia: Puerto Barrio (06²9’40”N, 74²4’24”O), 11.VIII.1938, Henry S. Dybas col., 1M (recebido dissecado) (FMNH). Cundinamarca: Puerto Salgar (05²8’12’N, 74³9’27’O), 30.VII.1938, C. H. Seevers

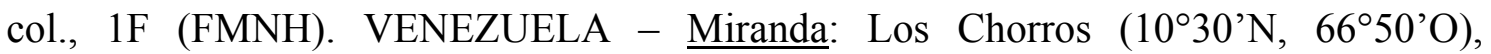
22.XII.1955, Garcia E. col. 1M (MZSP). GUIANA - Bartica: Kartabo (06²2’48”S, 58 40`48”O), 24.VII.1922, 1F (AMNH). SURINAME - Marowijne: Langaman Kondre $\left(05^{\circ} 43^{\prime} \mathrm{N}, 5^{\circ} 01^{\prime} \mathrm{O}\right)$, VIII.1965, B. Malkin col., 1F, 2M (MZSP). BRASIL Itapetininga [mais de uma localidade com o mesmo nome], 1ex. (MNRJ). Amapá: Rio Matapi, Desembocadura $\left(00^{\circ} 03^{`} \mathrm{~S}, 51^{\circ} 12^{\prime} \mathrm{O}\right), 18$. VI.1966, C. G. Froehlich col., 1M (MZSP). Amazonas: Campus - FUA (0305'45”S, 5957'58”O), 25.III.1982, A. T. S. Jatahy col., 1M (INPA); Fazenda NAF-6km 31 Estrada 13R 174 Mn (02\%44'S, 6002’O), 31.IV.1976, Mário Dantas col., 1F (INPA); Rio Uneiuxi, Aldeia Rosado

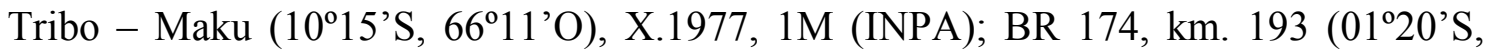
60²2’O), 09.II.1978, D. Chariwood col., 1ex. (INPA); Usina Hidroelétrica Balbina

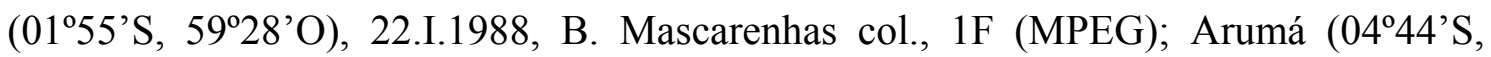
6209’O), 10.X.1935, Coleção Dr. G. H. Nick, 1ex. MZUSP; Benjamin Constant (04²2’28’S, 7001'47’O), XII.1979, A. Lise col., 1F (MCNZ); IX.1960, L. G. Pereira col., 1M (DCMP); mesmo município, Rio Javari (04²2’28’S, 7001’47’O), VI.1969, Coleção Dirings, 1F (MZSP); mesmo município, Rio Javari - Alto Amazonas, Coleção Dirings, 2exs. MZUSP; Manaus (0306’48”S, 6001'31’O), 07.III.1958, Elias e Roppa col., 1M (MNRJ); VIII.1941, A. Parko col., 2ex., 1F (MNRJ); 05.X.1978, R. C. Best. col., 1F (INPA); mesmo município, AM_10, km 54, BI-2, 20.V.2003, F. F. Xavier Fo col., 1M (INPA); Nova Olinda, Rio Madeira (0353'31'S, 5905'30”O), 10.II.1963, E. V. da Silva col., 1M (INPA); 11.II.1963, E. V. da Silva col., 1M (INPA); Novo 


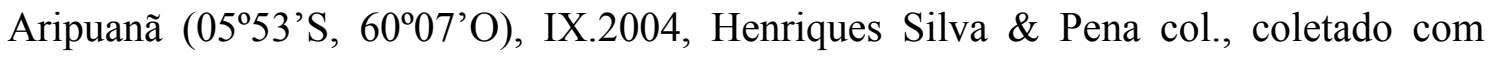
armadilha de luz mista e BLB em floresta úmida, 1F (INPA); Querari $\left(01^{\circ} 05^{\prime} \mathrm{N}\right.$, $\left.69^{\circ} 51^{\prime} \mathrm{O}\right), 2^{\circ}$ Pelotão, 09.V. 1993, J. Vidal col., coletados em tronco de árvore, 1M, 1F (INPA); Remate de Males (04²1'55”S, 70¹1'35”O), Rio Javary - Alt. Amazonas,

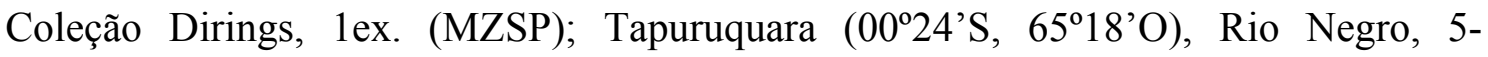
11.II.1963, J. Bechyné col., 1F (MZSP); Taracuá (0327’15”S, 6251’05”O), Rio Uaupés, VIII.1966, Pereira \& Machado col., 1F (MZSP). Pará: E. Sefer col., 1F (MNRJ); [Reserva Florestal de] Gorotire (07030’S, 52º), 03-06.X.1985, W. L. Overal col., 1ex. (MPEG); Rio Tocantins, Ilha, 27.VII.1984, B. Mascarenhas col., 1F ,1M (MPEG); 07.VII.1984, B. Mascarenhas, 1F, 1M (MPEG); Rio Trombetas, Est. Cruz Alta, 24.XI.1982, C. Fonseca col., 1M (INPA); Belém (01²7’'S, 48²9’O), 24.V.1987, M. F. Torres col., 1M (MPEG); Benevides (01²2’S, 48¹5’O), Estação Neópolis, Sitio D. Boca, VII.1991, W. Overal col., 1F (MPEG); Itaituba (04²13'S, 5601'O), Santarenzinho-Rio Tapajós, IX.1961, Coleção Dirings, 1M (MZSP), Mocajuba (02³5'S, 49³0'O), Mangabeira, X.1952, Orlando Rego col., Coleção Campos Seabra, 1F (MNRJ); Óbidos (0154’30”S, 55³1'08”O), I.1956, Coleção Dirings, 1F (MZSP); VII.1956, Coleção Campos Seabra, 1M (MNRJ); mesmo município, Colônia Rio Branco, V.1953, José Brazilino col., Coleção Campos Seabra, 1F (MNRJ); Oriximiná (0145'55”S, 5551'50”O), boca do Cuminá-Miri, 19-26.I.1968, Exp. Perm. Amaz. col., 1F (MZSP); Serraria, Serra Norte, 18.I.1985, W. França col., 1M, 4F (MPEG); Tucuruí (04²5’0.001’S, 49³1'59.988’O), Rio Tocantins, Ilha Tocantins, 16.VII.1984, B. Mascarenhas col., 4F, 2M (MPEG); 26.VII.1984, B. Mascarenhas col., 1ex. (MPEG).Maranhão: 50 km E Canindé (02³3'36”S, 46²8’48”O), Igarapé Gurupi Uma Aldeia Araçu, V.1963, B. Malkin col., 2M (MZSP). Mato Grosso: Cáceres (16 $04^{\prime}$ S, 57041'O), Porto Esperidião, XI.1984, Magno e Alvarenga col., 1M (MNRJ); Salobra, X. 1938, 1M (MZSP). Rondônia: Forte Príncipe da Beira (12²5’S, 64²5’O), 19.XI - 03.XII.1967, G. R. Kloss col., 1M (MZSP), Ji-Paraná (1050’S, 6158’O), Novo Tupassi, 07.X.1984, R. B. Neto col., 1F (MPEG). Acre: Xapuri (10³9’S, 68³1'O), Pimenteira, 06.IV.1996, A. Bonaldo col., 2F (MCNZ). Goiás: Jataí (1753’S, 51ํ4’ㅇ), Fazenda Aceiro, X.1962, Exp. Dep. Zool. col., 1M (MZSP). Minas Gerais: Rosário Oeste, 1ex. (DCMP). Espírito Santo: Linhares (19²5’S, 4004’O), Parque Sooretama, 21.X.1959, D. Zajclw col., 1F (MNRJ); mesmo município, Lagoa do Macucu, 22.X.1972, J. P. Abravaya col., 1ex., 1F (LACM); 25.X.1973, J. P. Abravaya col., 1F 
(LACM); Córrego Itá [Barra da São Francisco] (1845’S, 4052’O), XI. 1956, W.

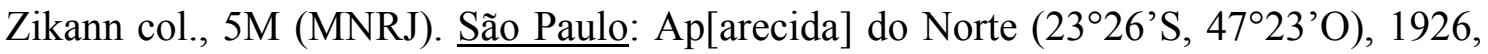

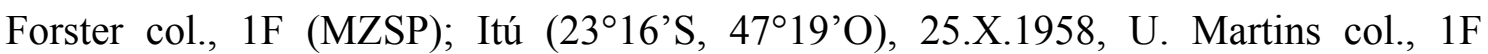
(MZSP); Pedregulho (20¹6’S, 47²9’O), 08.XI.1962, Claudionor Elias col., 1M (DCMP); Peruíbe (24¹9'S, 47º), 07.I.1938, Zellibor-Hauff col., Coleção Dr. G. H.

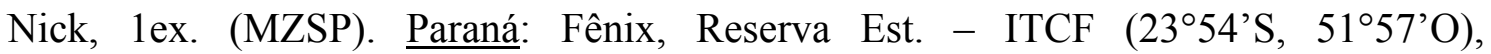
04.XI.1986, Lev. Ent. PROFAUPAR, 1M, (DCMP); 03.XI.1986, Lev. Ent. PROFAUPAR, 1F (DCMP); 29.XI.1986, Lev. Ent. PROFAUPAR, 1F (DCMP);

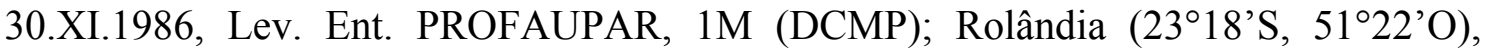
I.1954, A. Maller col., Coleção Campos Seabra, 1F (MNRJ); I.1954, A. Maller col., 1M (DCMP); mesmo município, Norte Paraná, IV.1948, Coleção Dirings, 1F (MZSP). Santa Catarina: Corupá (26²6’S, 49¹4’O), X.I.1937, A. Maller col., 1ex. (MNRJ); I.1952, A. Maller col., Coleção Campos Seabra, 1ex. (MNRJ); 60m, 1M (DCMP), Joinville (26²18'S, 4850'O), II.1954, Coleção Dirings, 1F (MZSP); Nova Teotônia

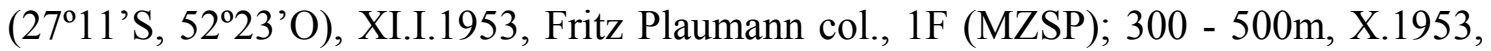
Fritz Plaumann col., Coleção Dr. G.H. Nick, III.1954, 1ex. (MZSP). Rio Grande do Sul: Triunfo (2956'S, 51 $\left.{ }^{\circ} 43^{\prime} \mathrm{O}\right)$, Copesul, 05.II.2003, R. S. Araujo col., 1M (MCNZ). EQUADOR - Napo: Yasuni Scientific Station, 210m (0040'36”S, 76²4'02”O), 21.IV.1998, K. Will col., 1F, 1M (recebidos dissecados) (EMEC); Puerto Misahualli (0102’03”S, 77³9’49”O), 10.IX.1997, K. Will col., 1M (EMEC). Pastaza: Cusuimi, Rio Cusuimi 150km SE Puyo, 300m., elev. 320m., 15-31.V.1971, B. Malkin col., 1M (FMNH); 18-23.VII.1971, B. Malkin col., 4M (FMNH); elev. 320m., 1F (FMNH). PERU - Departamento de Loreto: $15 \mathrm{~km}$ de Ucayali no R. Calleria, Colônia Calleria, 10.IX - 15.X.1961, B. Malkin col., 1F (FMNH); 01 - 05.X.1961, B. Malkin col., 1F (FMNH); 05 - 10.X.1961, B. Malkin col., 1F (FMNH); Rio Napo, 80 milhas a NE de Iquitos (02³8'S, 7207'50”O), 07.XII.1980, T. King col., 1M (FMNH). Ica: Chanchamayo $\left(1^{\circ} 08^{\prime} \mathrm{S}, 75^{\circ} 41^{\prime} \mathrm{O}\right)$, E. G. Smyth col., 1ex. (LACM). BOLÍVIA Departamento del Beni: Vila indígena Chacobo no Rio Benicito $\left(12^{\circ} 20^{\prime} \mathrm{S}, 66^{\circ} \mathrm{O}\right)$, 31.VII-02.VIII.1960, B. Malkin col., 2F (recebido dissecado), 1M (FMNH); 0110.VII.1960, B. Malkin col., 1F (recebido dissecado) (FMNH). Santa Cruz: Sara

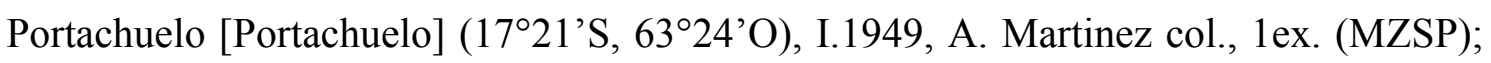
Chapare $\left(15^{\circ} 30^{\prime} \mathrm{S}, 65^{\circ} \mathrm{O}\right), 400 \mathrm{~m}, \mathrm{XI} .1966,1 \mathrm{~F}$ (MZSP); Província de Ichilo, Buena Vista 
(17²7’S, 6340’O), 400m, X 1962, 1M (MZSP). PARAGUAI - Passo C.boi (ilegível), 200m, XII.1950, Coleção G. H. Nick, 2exs. (MZSP).

\section{Discussão:}

Apresenta dimorfismo sexual; os machos têm duas fileiras de cerdas escamiformes na superfície ventral dos tarsômeros anteriores 2-3 e a diferença de tamanho entre os tarsômeros 3 e 4 é maior do a diferença entre os demais tarsômeros.

M. simplex é muito parecida com $M$. lafertii, principalmente pelo prosterno fortemente côncavo e o comprimento do metatrocânter ter um comprimento maior do que a metade do comprimento do fêmur posterior. Porém, a ausência de cerdas no prosterno, mesostero e metasterno, além da margem do pronoto glabra em M. lafertii, e a presença de cerdas nessas regiões em $M$. simplex, permite facilmente diferenciá-los.

Os espécimens de $M$. simplex examinados têm a fileira mediana ventral da perna posterior um pouco mais longa do que nas demais espécies.

Há registro de ocorrência de M. simplex na América Central (Costa Rica, Trinidad e Tobago) e América do Sul (Colômbia, Venezuela, Guiana, Suriname, Brasil, Equador, Peru, Bolívia e Paraguai), sendo encontrados em todos os meses do ano. Alguns exemplares foram coletados com armadilha de luz mista e um indivíduo foi coletado em câmara de lixo de Atta sp. 


\section{DiscuSSÃo e CONCLUSÕES}

\section{Estudo Morfológico (e algumas inferências bionômicas)}

O estudo morfológico minucioso possibilitou a análise de muitos caracteres importantes na definição das espécies, como por exemplo, a asa reduzida de Morion brasiliensis, que até o presente não foi publicada. Foi possível também encontrar muitas variações intraespecíficas, sendo quase impossível encontrar dois indivíduos idênticos, principalmente em relação ao número de cerdas. Desse modo, foram consideradas como características apenas a presença ou não das cerdas e a localização destas. Além disso, o que contribuiu para deixar o estudo um pouco mais complicado foi que praticamente todos os indivíduos são assimétricos, mesmo em relação à quetotaxia.

Não foi possível encontrar características exclusivas para todas as espécies, sendo a definição das mesmas baseada numa combinação de caracteres.

A maioria das espécies estudadas apresenta dimorfismo sexual. Tais diferenças entre machos e fêmeas podem ser mais ou menos evidentes. M. brasiliensis apresenta algumas diferenças em relação à mandíbula, fêmures, tíbias e tarsos, enquanto que $M$. lafertii não possui diferenças externas relacionadas ao sexo. As outras espécies (e apenas um exemplar de $M$. arida) possuem diferenças no tarso: apenas os machos possuem cerdas escamiformes na superfície ventral de alguns tarsômeros anteriores.

A presença de dimorfismo sexual em todas as espécies, com exceção de $M$. lafertii e da maioria dos exemplares analisados de $M$. arida, mostra que tal diferenciação possa ter um grande valor adaptativo, pois possivelmente os machos com os tarsômeros mais desenvolvidos e com presença de cerdas escamiformes embaixo destes foram selecionados por conseguirem maior fixação no dorso da fêmea durante seu comportamento de cópula. Com base nas informações sobre o grupo não é possível explicar o motivo para tal dimorfismo não aparecer nos machos de M. lafertii e em grande parte dos $M$. arida. Um estudo detalhado do comportamento das espécies de 
Morion poderia contribuir enormemente para entendimento dessa interessante variação intragenérica.

As anotações nos rótulos dos exemplares indicaram algumas informações a respeito de técnicas de coletas utilizadas na captura de Morion e sobre a biologia dos indivíduos. Alguns indivíduos foram coletados com armadilha de Malaise, luz, luz negra, luz mista, coleta manual e coleta manual com auxílio de rede entomológica. No que se diz respeito ao comportamento dos indivíduos, alguns exemplares de $M$. simplex e M.lafertii foram encontrados em câmara de lixo de formigas saúva (Atta sp. e Atta mexicana), indicando que há algum tipo de relação entre populações de formiga e de Morion e, confirmando os dados da literatura, alguns indivíduos foram coletados sob troncos podres. Há registro de coletas de Morion durante todos os meses do ano.

Embora um estudo de revisão das espécies de Morion do hemisfério Oeste já tenha sido feito em 1968, nota-se claramente que o presente estudo possibilitou um aumento significativo da distribuição geográfica das espécies (principalmente de $M$. boliviensis, M. brasiliensis, M. simplex, M. cycloma e M. cordata) e a análise de novas estruturas importantes na caracterização das espécies (por exemplo asa membranosa, que varia em quase todas as espécies) possibilitou dar maior robustez à validade das espécies.

\section{Distribuição Geográfica}

As coordenadas geográficas das localidades disponíveis nos exemplares de Morion estudados e da literatura foram levantadas.

Nota-se que os Morion das Américas ocorrem entre as latitudes $44^{\circ} 20^{\prime} \mathrm{N}$ e $30^{\circ} 02^{\prime}$ S, sendo encontrados em quase todos os países das Américas, incluindo: Estados Unidos, México, República Dominicana, El Salvador, Guatemala, Honduras, Nicarágua, Costa Rica, Panamá, Colômbia, Venezuela, Trinidad e Tobago, Guiana, Suriname, Guiana Francesa, Brasil, Peru, Bolívia, Paraguai, Argentina e Equador.

Claramente é possível notar que algumas espécies apresentam ampla distribuição, enquanto outras estão limitadas a áreas menores (de acordo com os espécimes já encontrados). 
Entre as espécies que ocorrem em território sul-americano, somente $M$. brasiliensis tem uma distribuição mais restrita (pranchas 50, 55, 60). M. costigera ocorre apenas na América Central e também apresenta distribuição limitada (prancha 61). O que há em comum em ambas as espécies é o fato de serem braquípteras, o que realmente pode ter contribuído na impossibilidade de uma distribuição mais ampla. De acordo com artigos citados na introdução da presente dissertação, geralmente as espécies braquípteras são mais freqüentemente encontradas em montanhas altas e/ou em ilhas, deste modo, o estudo dessas duas espécies reforça essas observações, já que grande parte dos M. brasiliensis foi encontrada em montanhas (Estação Biológica de Boracéia e Serra Macaé) e em ilhas (Ilha dos Búzios e Ilha da Vitória). Do mesmo modo, exemplares de $M$. costigera só foram encontrados em uma ilha, a Jamaica.

Entre os representantes da América do Norte, M. arida (pranchas 49, 54 e 59) e M. monilicornis (pranchas 52, 57 e 63) também apresentam uma distribuição não muito ampla, ocorrendo no sudoeste e sudeste/centro-sul do continente, respectivamente. Nenhuma dessas espécies apresenta braquipteria, deste modo, provavelmente barreiras físicas sejam responsáveis pela separação espacial, no caso possivelmente as Montanhas Rochosas.

Embora algumas partes das Montanhas Rochosas datem do período précambriano, as partes mais jovens soerguiram durante o período Cretáceo superior (140 65 milhões de anos) (Wikipedia) e teve seu maior soerguimento há aproximadamente 5 milhões de anos (Sullivan, 1974). Sabendo-se que o fóssil de Carabidae mais antigo data de aproximadamente 155 milhões de anos (Grimaldi \& Engel, 2005) e que as áreas de distribuição das duas espécies estão divididas em grande parte pela área ocupada pelas Montanhas Rochosas, há possibilidade de essa formação geomorfológica ter sido um fator vicariante na formação dessas espécies. Porém um estudo filogenético seria de extrema importância para dar mais robustez para tal hipótese.

Com uma distribuição espacial razoável, porém não muito grande, aparecem $M$. lafertii (México e América Central) (pranchas 51, 56 e 62) e M. boliviensis (norte do Brasil e Bolívia) (pranchas 49, 54 e 59), esta última encontrada em duas áreas razoavelmente distantes uma da outra.

M. cycloma apresenta uma distribuição bastante ampla (pranchas 51, 56 e 62), cobrindo quase toda a América do Sul, porém não há registros na América Central embora haja dois registros norte-americanos. O fato de haver indivíduos nos Estados 
Unidos pode ser justificado por um erro de rotulagem ou pela possibilidade de espécimes poderem ter sido transportados pelo homem, já que indivíduos do gênero Morion vivem em troncos e a exportação de madeira no Brasil é bastante usual. A hipótese de não ter sido encontrado exemplares desta espécie na América Central devido à falta de coleta no local foi descartada, uma vez houve coleta na região; tal afirmação pode ser comprovada pelo grande número de exemplares de $M$. simplex, $M$. lafertii e $M$. cordata coletados na área, além da espécie aparentemente endêmica $M$. costigera.

As espécies mais amplamente distribuídas entre os Morion das Américas são $M$. cordata (pranchas 50, 55 e 60) e M. simplex (pranchas 52, 57 e 63), cobrindo quase todo o território sul-americano e boa parte da América Central. Não há uma boa explicação que justifique o fato de apenas essas duas espécies terem se espalhado tanto, porém é compreendido que isto seja possível já que são predadores e podem dispersar-se livremente por onde haja algum tipo de presa. É prudente também mencionar que foi encontrado um único exemplar de $M$. cordata coletado no leste dos Estados Unidos (bastante distante do local de coleta dos demais exemplares); as explicações para tal fato são as mesmas indicadas para os espécimes americanos de M. cycloma.

No trabalho de Reichardt de 1971, onde são analisadas espécies de Carabidae da Venezuela, são citadas M. simplex e M. monilicornis. Durante a análise do material estudado no presente trabalho foram encontrados exemplares de $M$. simplex venezuelanos, mas nenhum exemplar de M. monilicornis coletado fora dos Estados Unidos. Dentre os espécimes de M. monilicornis venezuelanos citados por Reichardt, dois exemplares pertencem ao Museu de Zoologia da USP. Tais espécimes foram localizados nesta coleção, porém com uma segunda etiqueta identificando-os como $M$. cordata, colocada pelo próprio autor em 1972.

\section{Nomenclatura}

Devido à falta de informações na descrição original do gênero e a diferentes epítetos no nome escolhido, foi preciso determinar o gênero (masculino ou feminino) do nome genérico. A escolha foi optar pelo significado mais informativo (pedra preciosa, 
fig. 65a), atribuindo, deste modo, características físicas para o grupo (coloração negra e carapaça rígida), possibilitando desse modo uma padronização dos nomes específicos.

Outro problema nomenclatural está relacionado à espécie-tipo Harpalus monilicornis Latreille, 1806, considerada por alguns autores como descrita posteriormente a Morion georgiae (Palisot, 1821) (originalmente Scarites georgiae). Assim, a espécie válida seria $M$. georgiae, sendo M. monilicornis, sinônimo. Porém, Latreille em 1806 descreveu Harpalus monilicornis, já Palisot descreveu S. georgiae em um trabalho datado de 1805-1821. De acordo com o artigo 21.6 do Código Internacional de Nomenclatura Zoológica, quando um artigo é datado por um período e não por uma data específica, a data a ser considerada é o último dia deste período, ou seja, no caso, o último dia do ano de 1821. Como as duas espécies (M. monilicornis e M. georgiae) são sinônimas, a espécie válida é M. monilicornis pela lei da prioridade. Mesmo que se o trabalho de Palisot tivesse sido publicado em fascículos, Latreille descreveu antes, pois de acordo com o Index Animalium, Palisot fez a descrição em 1812, na página 107 do respectivo trabalho e, segundo o catálogo dos Geadephaga da América ao norte do México, Bousquet e LaRochelle (1993) consideram que Scarites georgiae também foi descrito na página 107 do mesmo trabalho, porém em 1811; ambas as referências indicam uma data para a descrição de $S$. georgiae posterior a 1810, ano da descrição de Harpalus monilicornis, considerada, portanto, espécie válida. Esta proposta é aceita também por Allen (1968).

\section{Considerações finais}

Morion é considerado um gênero mundial, assim, uma análise filogenética analisando as 41 espécies que compõem o grupo seria bastante interessante. Um trabalho desse tipo é de extrema importância para se verificar a validação do grupo, pois outros autores já notaram que há características larvais de Morion do hemisfério oriental (M. orientalis) que difere bastante das características encontradas em algumas espécies do Novo Mundo. Um estudo filogenético permitirá uma melhor análise do que provavelmente ocorreu durante a evolução do grupo, mostrando os possíveis níveis de parentesco entre as espécies. Poderia-se também verificar se a braquipteria ocorreu uma única vez no grupo ou se ocorreu em eventos distintos. 
Posteriormente, a sobreposição da filogenia com a distribuição geográfica encontrada mostrará uma hipótese robusta de quando e onde provavelmente ocorreram os eventos vicariantes de especiação do grupo. 


\section{REFERÊNCIAS BIBLIOGRÁFICAS}

Allen, R.T. 1968. A synopsis of the tribe Morionini in the western Hemisphere with descriptions of two new species (Coleoptera: Carabidae). Caribbean Journal of Science, v.8, n. 3-4, p. 141-163, 35 fig.

Andrewes, H.E. 1946. Stray notes on eastern Carabidae (Coleoptera) - I, II. Proccedings of the Royal Entomological Society of London. (B), v.15, p. 81-88.

Arnett, R.H., G.A. Samuelson \& G.M. Nishida. 1993. The Insect and $\underline{\text { Spider }} \underline{\text { Collections }}$ of the Word, Gainesville: Sandhill Crane Press. 277 p.

Arnett, R.H., G.A. Samuelson \& G.M. Nishida. The Insect and Spider Collections of the World. Disponível em: "http://hbs.bishopmuseum.org/codens/codens-r-us.html". Acesso em 24 de out. de 2006.

Blackwelder, R. E., 1945. Checklist of the Coleopterous Insects of Mexico, Central America, the West Indies, and South America. Bulletin of the United States National Museum, v.185, n. 3, p. 443-550.

Bousquet, Y. 1991. Carabidae (Adephaga) (Including Brachinidae, Cicindelidae, Omophronidae, Paussidae, Pseudomorphidae, Trachypachidae, etc.). In: Imature Insects (F. W. Stehr, ed.) vol.2, Dubuque: Kendall/Hunt Publishing Company, p. 306-310.

Bousquet, Y., LaRochelle. 1993. Catalogue of the geadephaga (Coleoptera: trachypachidae, rhysodidae, carabidae including Cicindelini) of America north of Mexico. Memoirs of the Entomological Society of Canada, v.167, p.160.

Brandmayr, P., C. B. Zanitti, G. Colombetta \& T. Z. Brandmayr. 1983. Analisi quatitativa sull 'origine del brachitterismo nelle ' faune' di coleotteri carabidi. Atti

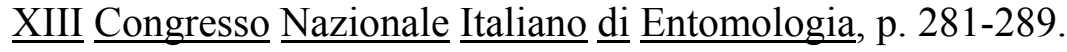

Chaudoir, M. 1837. Description de quelques nouveaux et de quelques espéces nouvelles

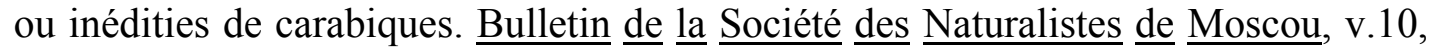
n. 3, p. 03-20.

Chaudoir, M. 1854 . Mémoire sur la famille des carabiques. Bulletin de la $\underline{\text { Société }}$

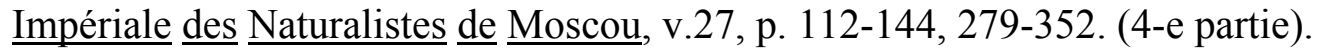

Chaudoir, M. 1880. Essai Monographique sur les Morionides. Bulletin de la $\underline{\text { Société }}$

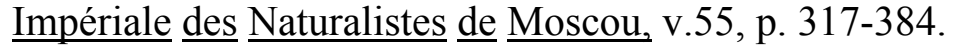

Chevrolat, L. A. A. 1841. Coléoptères du Mexique (209) (pentamerès carabiques et hydrocanthares). Magasin Zoologie, pls. 64-65. 
Costa, C., S. A. Vanin \& S. A. Casari-Chen. 1988. Larvas de Coleoptera do Brasil, São Paulo: Museu de Zoologia da Universidade de São Paulo. 282 p., 12 fig., 165 pls.

Darlington Jr., P. J. 1934. New West Indian Carabidae, with a list of the cuban species. Reprinted from Psyche, v. 41, n. 2, p. 66-131.

Darlington Jr., P. J. 1936. Variations and atrophy of flying wings of some carabid beetles. Annals of the Entomological Society of America, v.29, n. 1, p. 136-179, 3 pls.

Darlington Jr., P. J. 1941. West Indian Carabidae VI. The jamaican species, and their wings. Reprinted from Psyche, v. 48, no. 1, p. 10-15.

Darlington Jr., P. J. 1943. Carabidae of mountains and islands: data on the evolution of isolated faunas, and on atrophy of wings. Ecological Monographs, v.13, p. 37-61, 8 fig.

Darlington Jr., P. J. 1961. Australian carabid beetles V. Transition of wet forest faunas from New Guinea to Tasmania. Psyche, v.68, p. 1-24.

Darlington Jr., P. J. 1970. Coleoptera: Carabidae Including Cicindelinae. In: Insects of Micronesia, Honolulu, Hawaii: Published by the Museum, v. 15, no. 1, p. 1-49.

Darlington Jr., P. J. 1971. The carabid beetles of New Guinea. Part IV. General considerations; analysis and history of fauna; taxonomic supplement. Bulletin of the Museum of Comparative Zoology, v.142, p. 129-337.

David Grimaldi \& Michael S. Engel. 2005. Evolution of the Insects, New York: Cambridge University Press, 755 p.

Davidson, R.L \& Onore, G. 1990. Notes on the Morionini (Coleoptera: Carabidae) of Ecuador. Coleopterists Bulletin, v.44, n. 2, p. 216

Dean, J. 1980. Encounter Between Bombardier Beetles and Two Species of Toads (Bufo americanus, B. marinus): Speed of Prey-Capture Does Not Determine Success. Journal of Comparative Physiology A: Sensorial, Neural and Behavioral Physiology, v.135, n.1, p. 41-50.

Dejean, P. F. M. A. 1821. Catalogue de la collection de coléoptères $\underline{\text { de }} \underline{\text { M. }} \underline{\text { le }} \underline{\text { baron }}$ Dejean, Paris. 136 p.

Dejean, P. F. M. A. 1825. Spécies général des coléoptères de la collection de $\underline{\text { M. }} \underline{\text { le }}$ comte Dejean, v.1, Paris, 63 p.

Dejean, P. F. M. A. 1826. Spécies général des coleóptères. . ., vol. 2, 501 p.

Dejean, P. F. M. A. 1831. Spécies général des coleóptères. . ., vol. 5, 883 p. 
Deuve, T. 1993. L'abdomen et les genetalia des femelles de Coléoptères Adephaga.

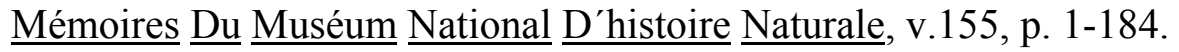

Erwin, T. L. 1979. 3.22. Thoughts on the evolutionary history of ground beetles: hypothesis generated from comparative faunal analyses of lowland forest sites in temperate and tropical regions, pp. 539-592. In: Carabid Beetles: Their Evolution, Natural History and Classification. (TL Erwin, et al.,editors), Dr. W. Junk, Publishers, The Hague. X. 635 p.

Erwin, T. L. 1985. The taxon pulse: a general pattern of lineage radiation and extinction among carabid beetle. In: Taxonomy, Phylogeny and Zoogeography of Beetles and

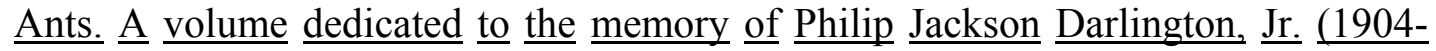
1983), Dordrecht: Dr. W. Junk Publishers, p. 437-472.

Erwin, T. L., K. D. y. M. W. 2002. La familia Carabidae. Disponível em: $<$ http://www.inbio.ac.cr/papers/carabidae/esp/index.html>. Acesso em 20 out. 2006.

ESRI (Environmental Systems Research Institute). 2002. Arcview GIS v. 3.3 - ArcView Global Information System. Redlands: ESRI.

Guérin-Mèneville, F. E. 1844a. Description de coléoptères nouveaux découverts par M.A. Niéto dans l'intérieur du Mexique. Revue Zoologique, p. 253-262.

Guérin-Mèneville, F. E. 1844b. Iconographie du règne animal de G. Cuvier..., 18291838 (1844), Paris, v. 7, insectes, 576 p., 104pls.

Horn, H. G. 1881. On the genera of Carabidae with special reference to the fauna of boreal America. Transactions of the American Entomological Society, v.9, p. 91196, illus.

Houaiss, A., Villar, M.S. 2001. Dicionário Eletrônico Houaiss da Língua Portuguesa. Ver. 1.0. [1 CD-ROM].

International Commission on Zoological Nomenclature. 1999. International Code of Zoological Nomenclature, London: The International Trust for Zoological Nomenclature 1999, $345 \mathrm{p}$.

Jeannel, R. 1948. Coléoptères carabiques de la région Malgache (deuxième partie). Faune de $\underline{1^{\prime} \text { Empire français, }}$ v.10, p. 373-766.

Jorge-Silva, M. E. 1979. Morfologia comparada das peças bucais de Carabidae (Coleoptera) Neotropicais. Tese [não publicada] apresentada ao Instituto de Biociências da Universidade de São Paulo como parte dos requisitos para a obtenção do título de Doutor em Ciências na área de Zoologia, 114 p., 803 fig.

Jorge-Silva, M. E.\& Costa, C. 1983. Larvae of neotropical Coleoptera 5: Carabidae, Morionini. Papéis Avulsos de Zoologia, São Paulo, v.35, n.1, p. 1-10. 
Kukalová-Peck, J. J. F. L. 1993. Evolution of the hind wing in Coleoptera. The Canadian Entomologist, v.125, p. 181-258.

Lacordaire, J. T. 1854. Histoire Naturelle des insectes. Genera des coléoptères ou expose methodique et critique de tous les genres proposés jusqu'ici dans et ordre d'insects, Paris, v.1, 486 p., illus.

Lamarck, M. le C. De. 1817. Historie Naturele de Animaux, Paris: De l'imprimerie d'Abel Lanoe, v.4.

Larousse, P. P. 1865-1890. Grand Dictionnaire Universel, Paris: Administration Du Grand Dictionnaire Universel. 15 tomos + 2 supl.

Latreille, P. A. 1806. Genera crustaceorum et insectorum secundum ordinem naturalem in familias disposta, iconibus exemplisque plurimus explicata, vol. 2, 280 p.; vol. 3, $258 \mathrm{p}$.

Latreille, P. A. 1810. Considération générales sur l'ordre naturel del animaux

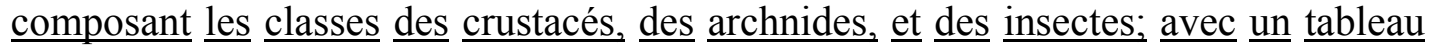
méthodique de leurs genres, disposés en familles, Paris, $444 \mathrm{p}$.

Lawrence, J. F. \& E. B. Britton 1994. Australian Beetles, Carlton, Victoria: Melbourne University Press, $\mathrm{x}+192 \mathrm{p}$.

Lorenz, W. 1998. Nomina carabidarum = a directory of the scientific names of ground beetles. (Insecta, Coleoptera "Geadephaga": Trachypachidae and Carabidae incl. Paussinae, Cicindelinae, Rhysodinae), Hormannstrasse 4, D-82327 Tutzing, Germany.: Publicado pelo autor.

Löser, S. 1970. Brutfürsorge und Brutpflege bei Laufkäfern der Gattung Abax. Zoologischer Anzeiger. Supplementband. (Verhandlugen der deutschen zoologischen Gesellschaft 1969), v.33, p. 322-326.

Marinoni, R. C., N. G. Ganho, M. L. Monné \& J. R. M. Mermudes. 2001. Hábitos $\underline{\text { Alimentares em Coleoptera (Insecta): compilação, organização de dados e novas }}$ informações sobre alimentação nas famílias de coleópteros, Ribeirão Preto: Holos Editora, $64 \mathrm{p}$.

Martínez, C. 2005. Introducción a los Escarabajos Carabidae (Coleoptera) de Colombia. Bogotá, Colômbia: Instituto de Investigaciones de Recursos Biológicos Alexander von Humboldt, 546 p.

Neave, S. A. 1940. A list of the names of genera and subgenera in Zoology from the tenth edition of Linnaeus 1758 to the end of 1835. v.3, London: The Zoological Society of London, $1065 \mathrm{p}$.

Nixon, K. C. \& Q. D. Wheeler. 1990. An amplification of the phylogenetic species concept. Cladistics, v.6, p. 211-223. 
Ober, K. A. 2002. Phylogenetic relationships of the carabid subfamily Harpalinae (Coleoptera) based on molecular sequence data. Molecular Phylogenetics and Evolution, August; v.24, n. 2, p. 228-248.

Ober, K. A. 2003. Arboreality and Morphological evolution in ground beetles (Carabidae: Harpalinae): testing the taxon pulse model. Evolution, June; v.57, n. 6, p. 1343-1358.

Palisot de Beauvois, A. M. F. J. 1805-1821. Insectes recueillis em $\underline{\text { Afrique et en }}$ Amérique, Paris (From Horn.), 276 p., 90 pls.

Quicherat, L. s.d. Novíssimo Diccionario Latino-Portuguez Etymologico, Prosodico, Historico, Geografico, Mythologico, Biographico, etc., Rio de Janeiro: Garinier, $\mathrm{xx}+1297 \mathrm{p}$.

Reichardt, H. 1971. Carabidae (Coleoptera) neotropicais: espécies venezuelanas e formas relacionadas. Papéis Avulsos de Zoologia, São-Paulo, v.24, n. 5, p. 73-91.

Reichardt. H. 1977. A synopsis of the genera of neotropical Carabidae (Insecta: Coleoptera). Quaestiones Entomologicae, v.13, p. 346-493.

Reiche, L. 1842. Coléoptères de Colombie. Revue Zoologique, p. 377.

Ridley, M. 1996. Evolution, Cambrige: Blackwell Science, xxi+719 p.

Schenkling, S. 1925. Carabidae II. Pars 104, p. 479-484. In: S. Schenkling. Coleopterorum Catalogus auspiciis et auxilio W. Junk, Berlin: W. Junk.

Sharp, D. \& F. Muir 1912. The comparative anatomy of the male genital tube in Coleoptera. Transactions of the Entomological Society of London, p. 477-642, illus. (Reprinted whithout change, 1969).

Sherborn, C. D. 1922. Index Animalium, London: British Museum.

Straneo, S. L. 1952. I. Pterostichini dell'Angola (Coleoptera, Carabidae). Museo do Dundo, Subsidos para o estudio da Biologia na Lunda, Lisboa: Publicacoes

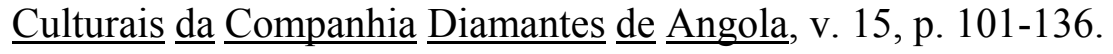

Sullivan, W. 1974. Continents in Motion, New York - St. Louis - San Francisco México - Toronto - Dusseldorf: McGraw - Hill Book Company, 399 p.

Tanner, V. M. 1927. A preliminary study of the genitalia of female Coleoptera. Transactions of the American Entomological Society, v.53, p. 5-50, 15 pls.

Thompson, R. G. 1977. A redescripton of the larva of Morion cordatus Chaudoir (Coleoptera: Carabidae; Morionini). Coleopterists's Bulletin, v.31, n. 2, p. 159-164, illust. 
Torre-Bueno, J. R. de la 1989. The Torre-Bueno Glossary of Entomology, including

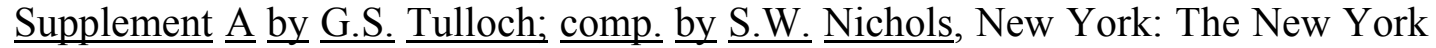
Entomological Society, 840 p.

Wikipedia contributors. 2006. Morion. Wikipedia, The Free Encyclopedia. Disponível em: $<$ http://en.wikipedia.org/w/index.php?title=Morion\&oldid $=77040519>$. Acesso em: 20 out. 2006.

Will, K. W. 2003. Review and Cladistic Analysis of the Generic-Level Taxa of Morionini Brullé (Coleoptera: Carabidae). Pan-Pacific Entomologist, v.79, n. 3/4, p. 212-229. 

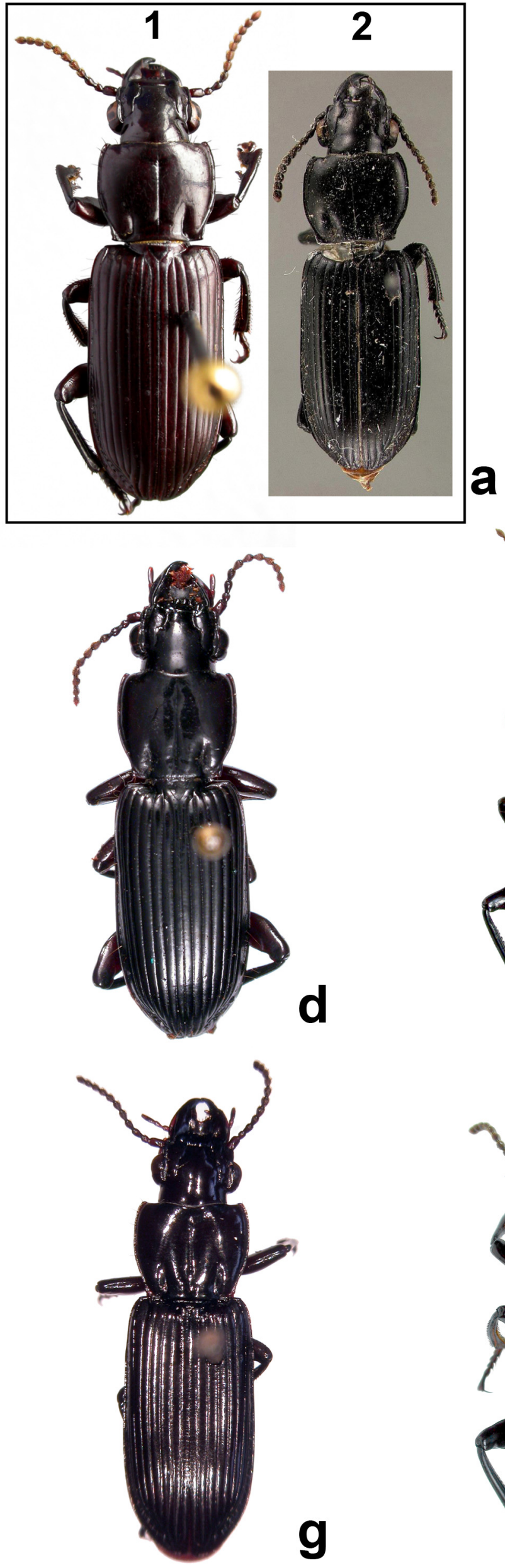
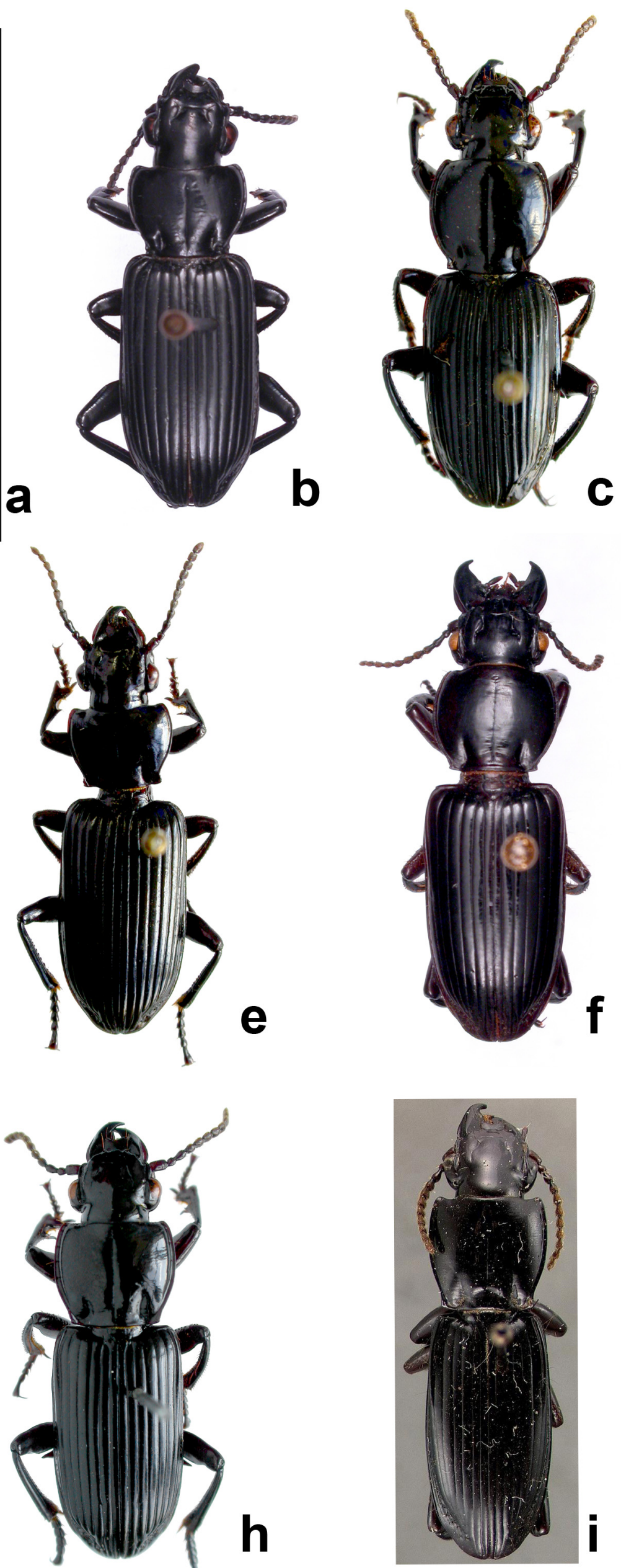

Prancha 01: Habitus dorsal. a. Morion arida (1. fêmea (15 mm); 2. holótipo macho); b. M. boliviensis (19 mm); c. M. brasiliensis (19 mm); d. M. cordata $(17 \mathrm{~mm})$; e. M. cycloma $(19 \mathrm{~mm})$; f. M. lafertii $(22$ $\mathrm{mm})$; g. M. monilicornis (17 mm); h. M. simplex (20 mm); i. M. costigera (holótipo). 

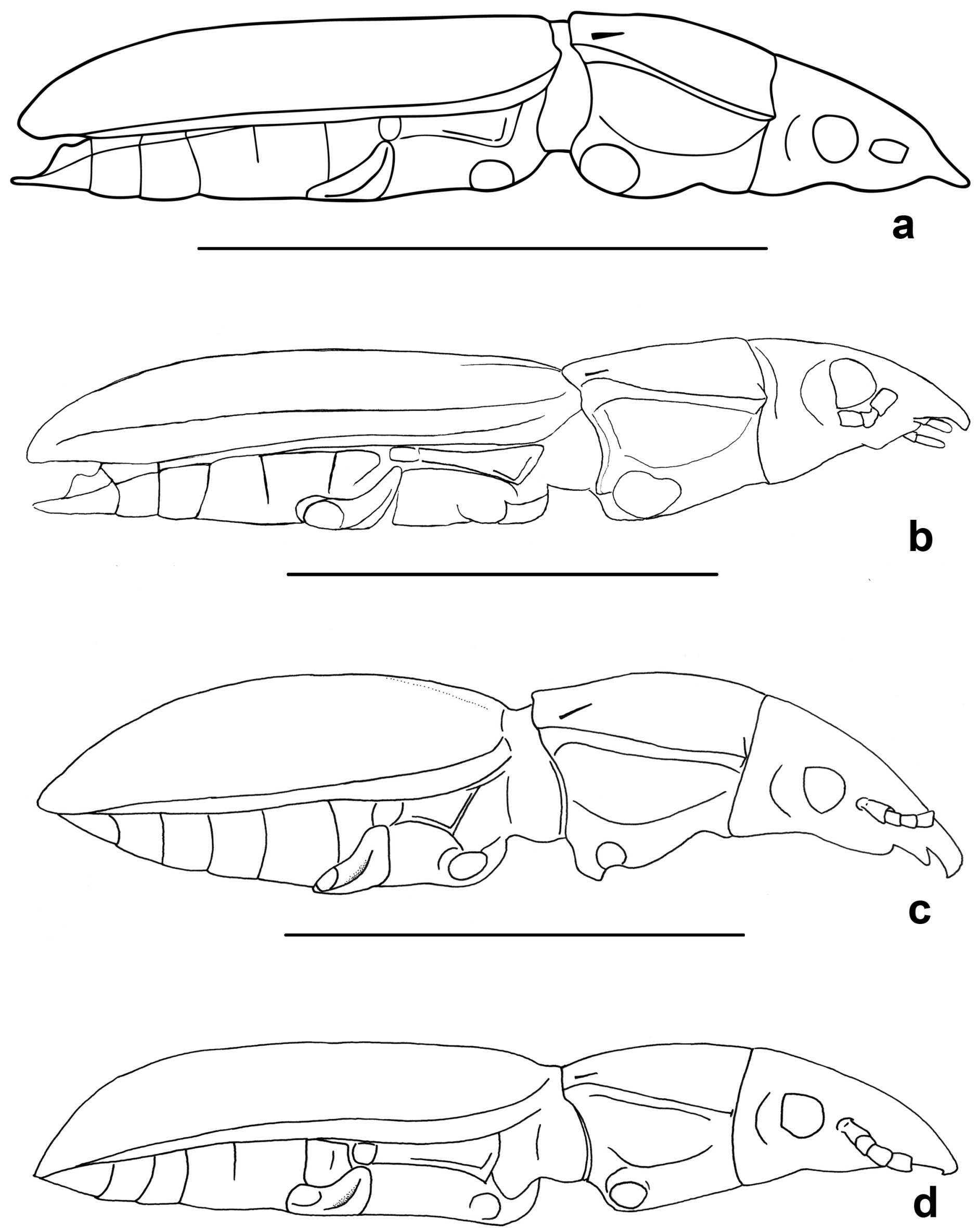

Prancha 02: Vista lateral de Morion (pernas, parte das antenas e cerdas não representadas). a. $M$. arida; b. M. boliviensis; c. M. brasiliensis; d. M. cordata. Barras $=10 \mathrm{~mm}$. 

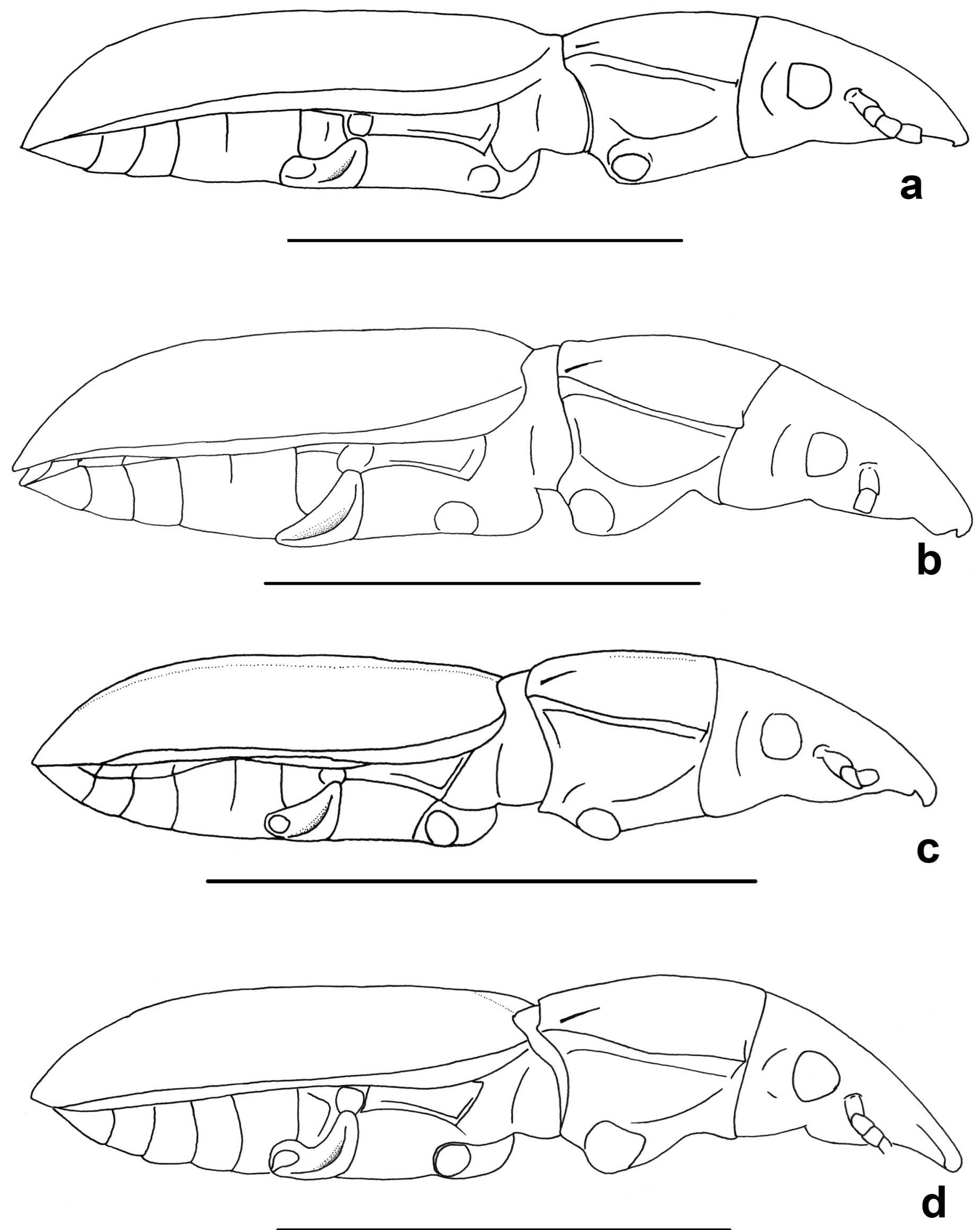

Prancha 03: Vista lateral de Morion (pernas, parte das antenas e cerdas não representadas). a. M. cycloma; b. M. lafertii; c. M. monilicornis; d. M. simplex. Barras $=10 \mathrm{~mm}$. 

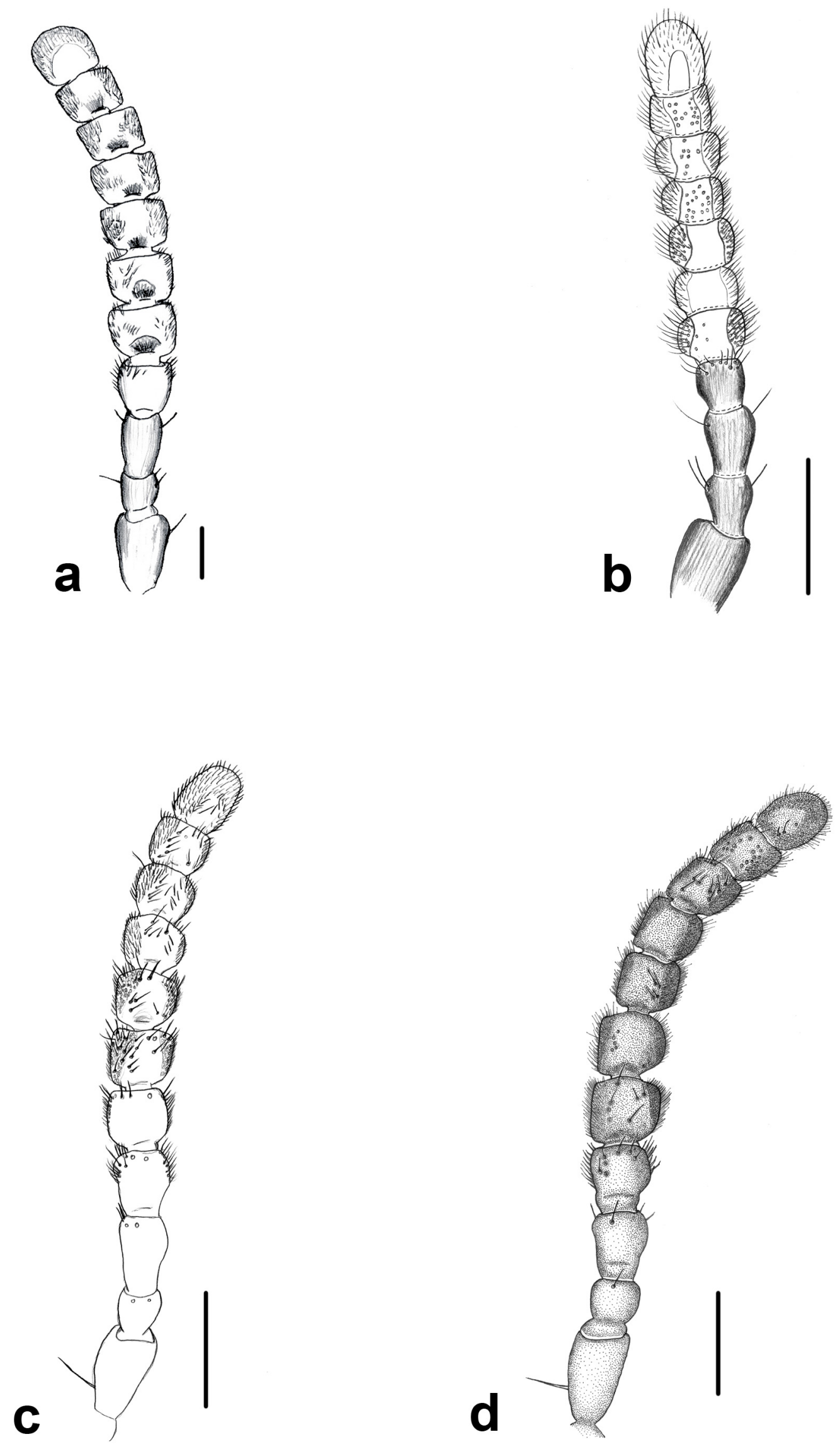

Prancha 04: Antenas. a. Morion boliviensis; b. M. brasiliensis; c. M. cycloma; d. M. simplex. Barras $=1 \mathrm{~mm}$. 

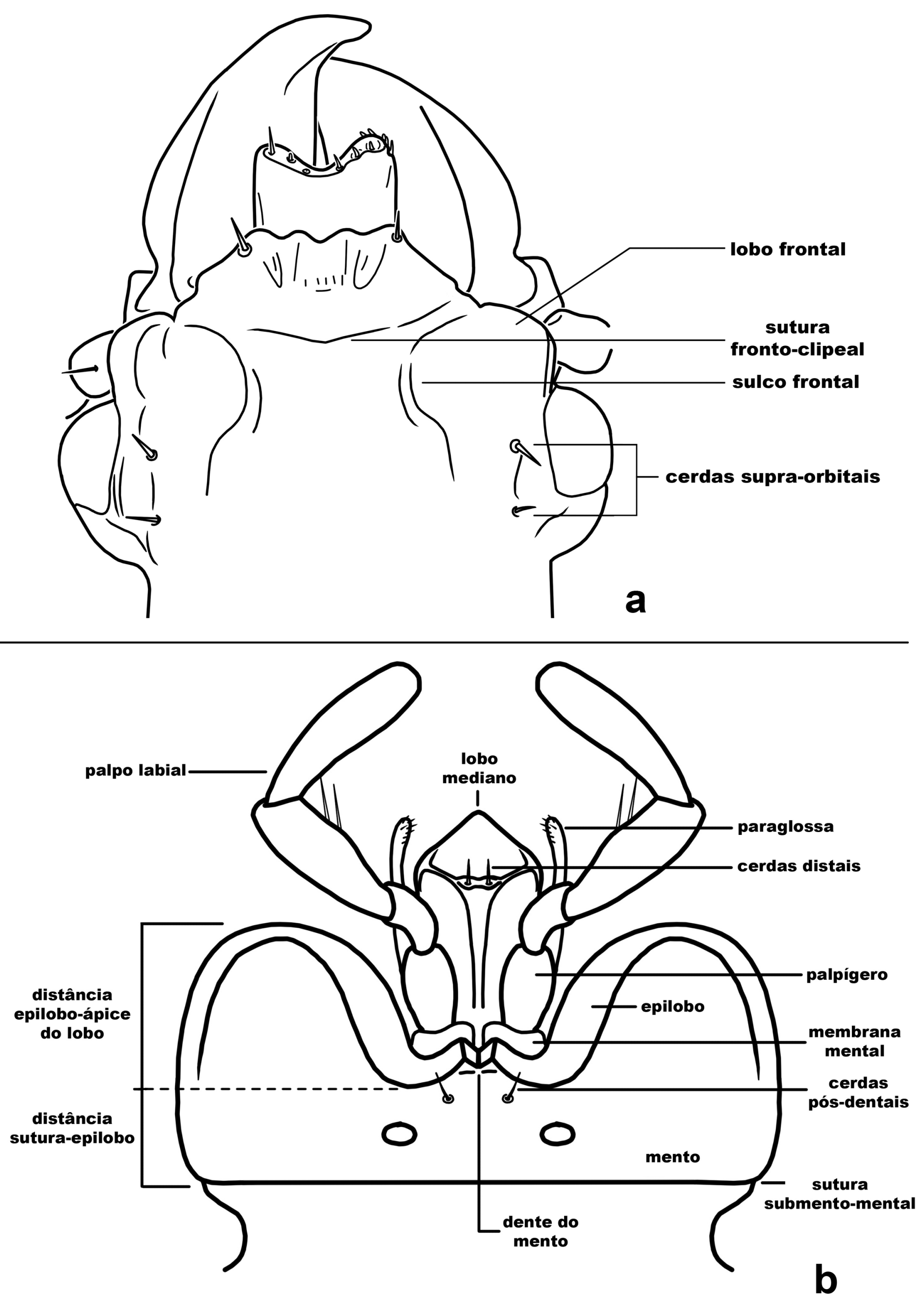

Prancha 05: Desenhos esquemáticos. a. cabeça (dorsal); b. lábio (ventral). 

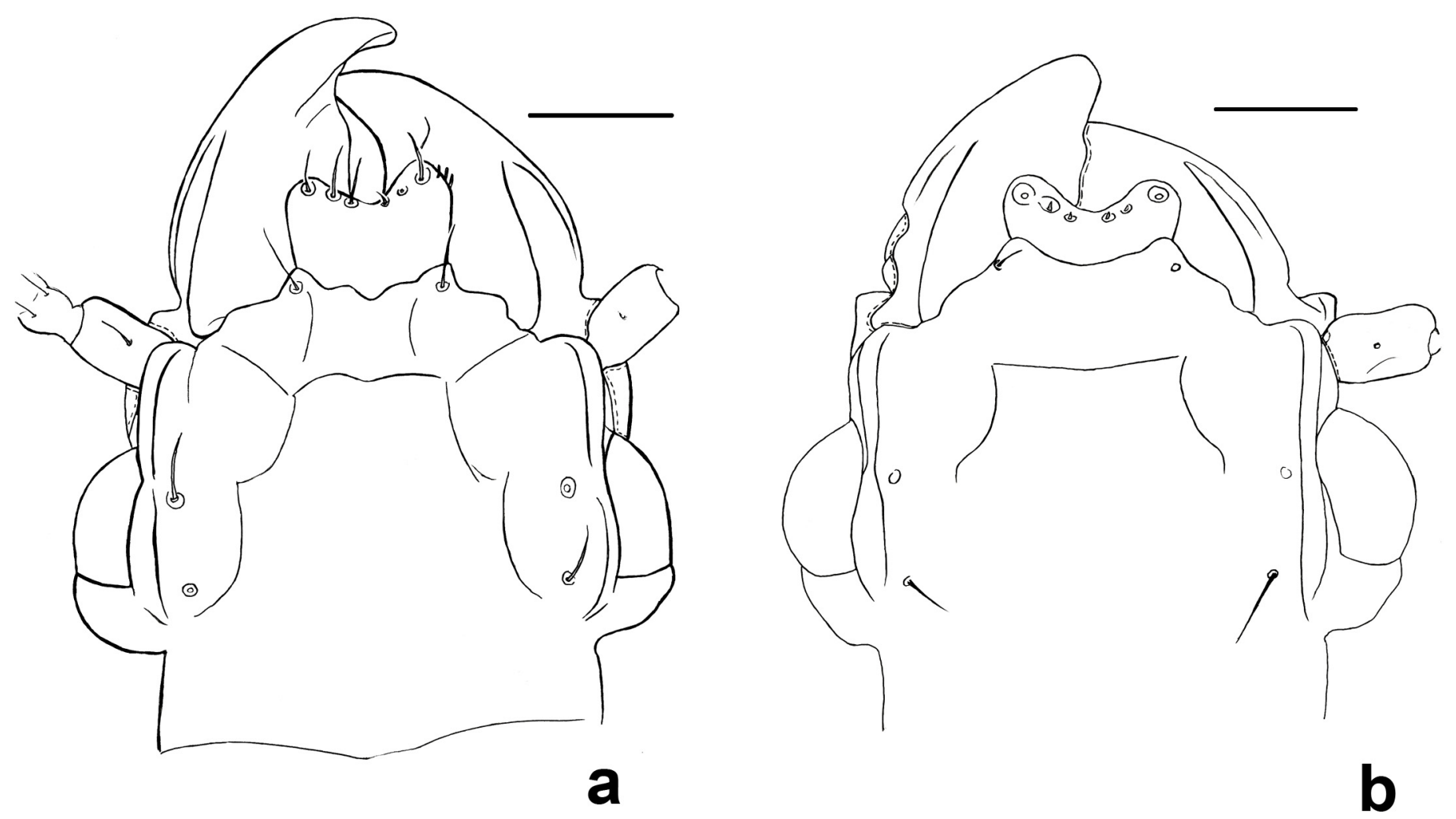

b
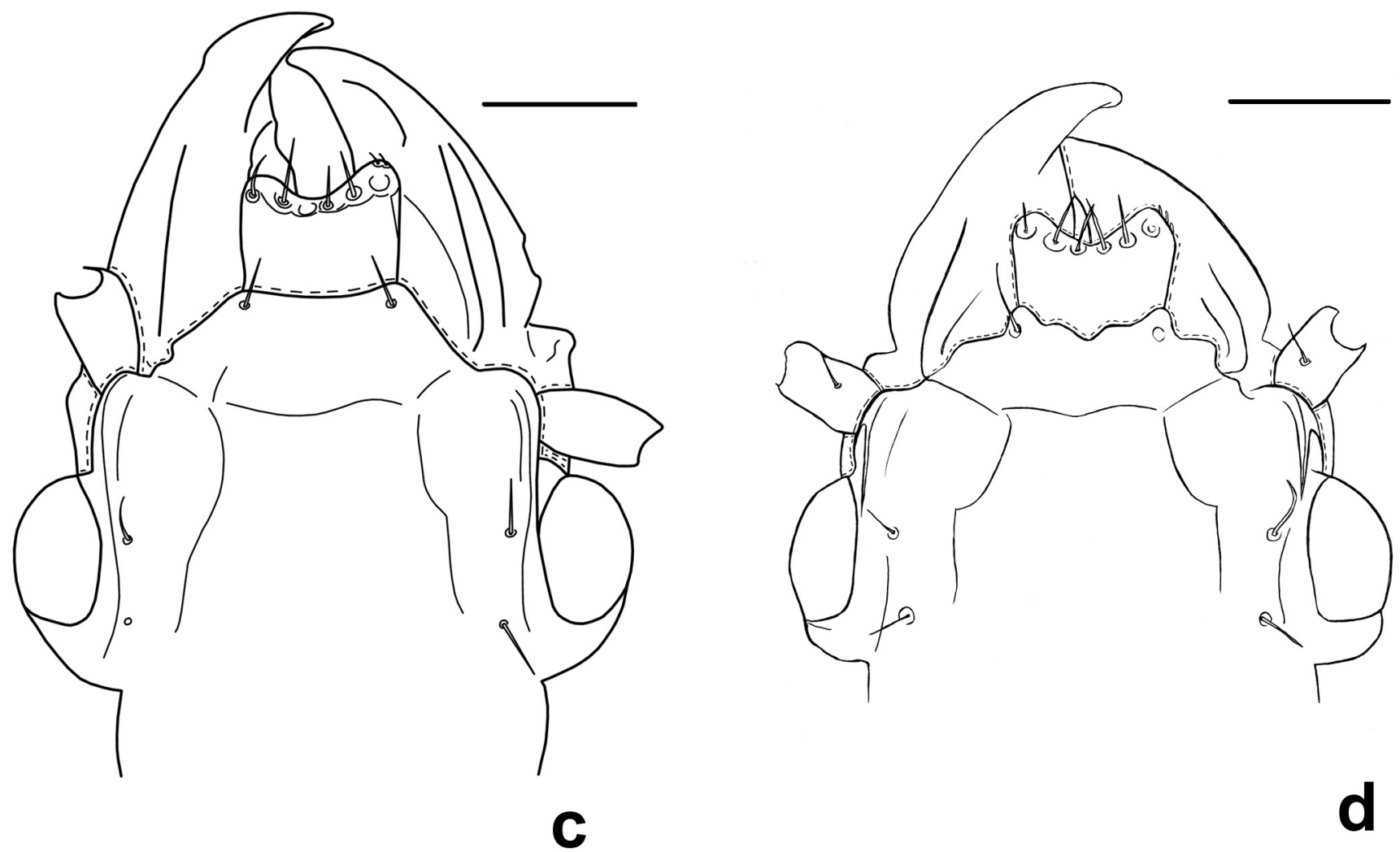

Prancha 06: Cabeça (dorsal). a. Morion arida; b. M. boliviensis; c. M. brasiliensis; d. M. cordata. Barras $=1 \mathrm{~mm}$. 

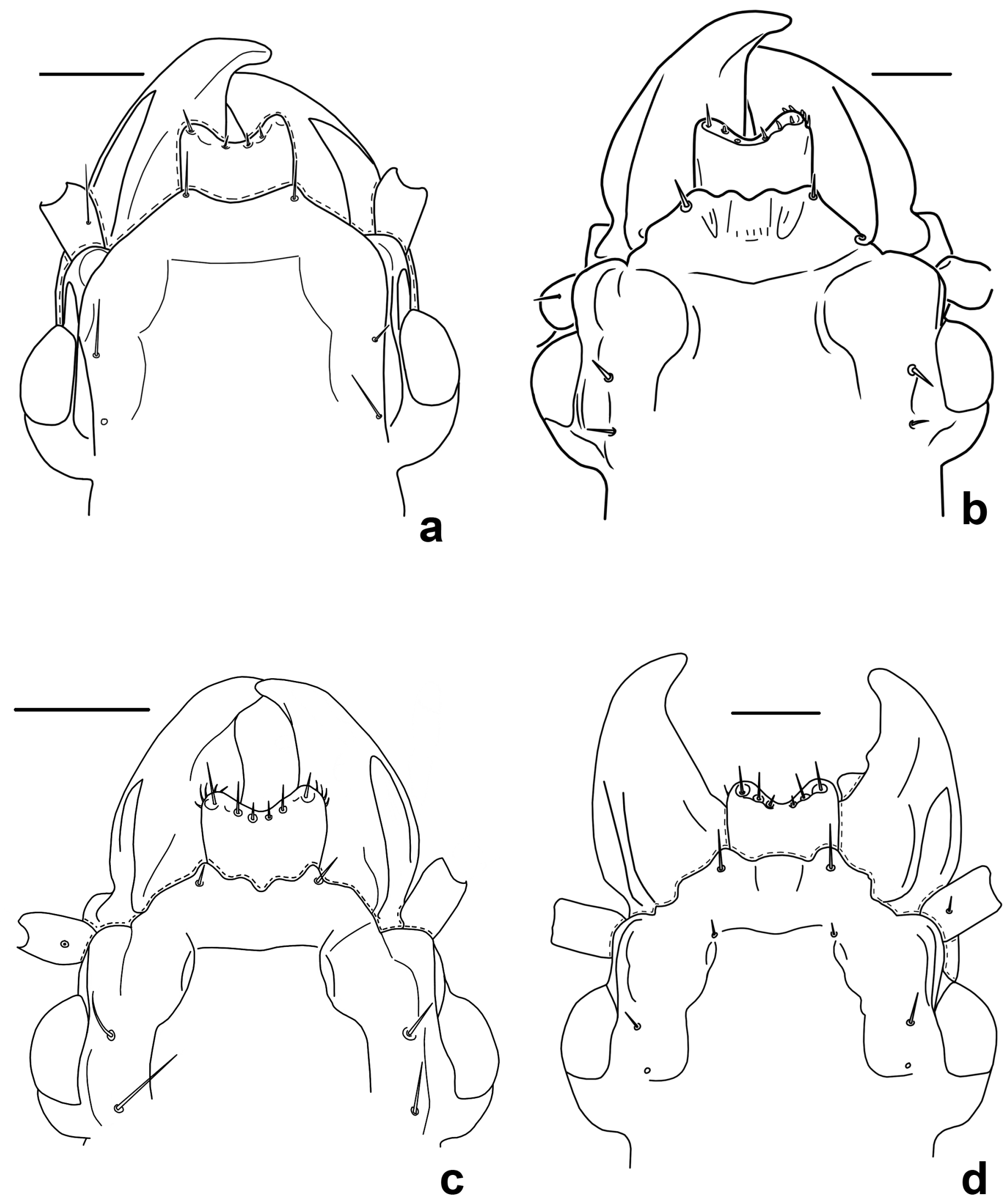

Prancha 07: Cabeça (dorsal). a. Morion cycloma; b. M. lafertii; c. M. monilicornis; d. M. simplex. Barras $=1 \mathrm{~mm}$. 

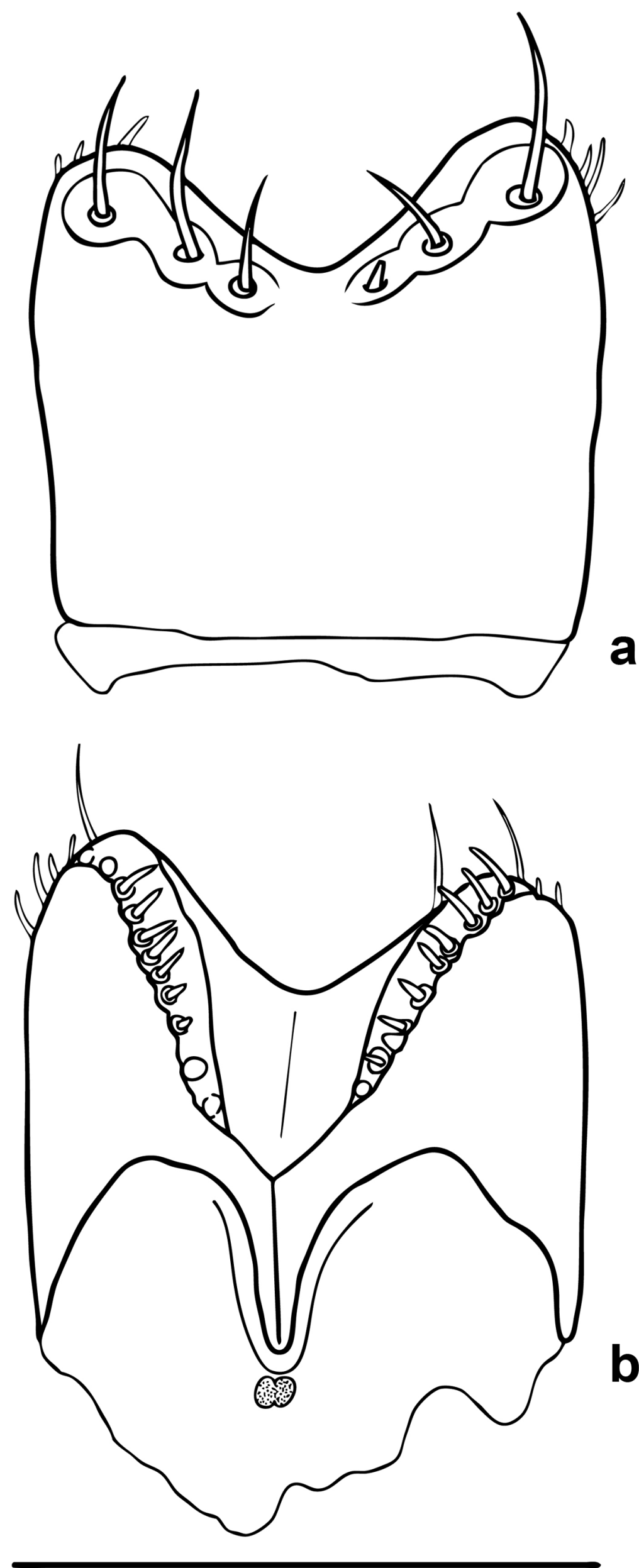

Prancha 08: Labro e epifaringe de Morion. a. labro; b. epifaringe. Barra $=1 \mathrm{~mm}$. 

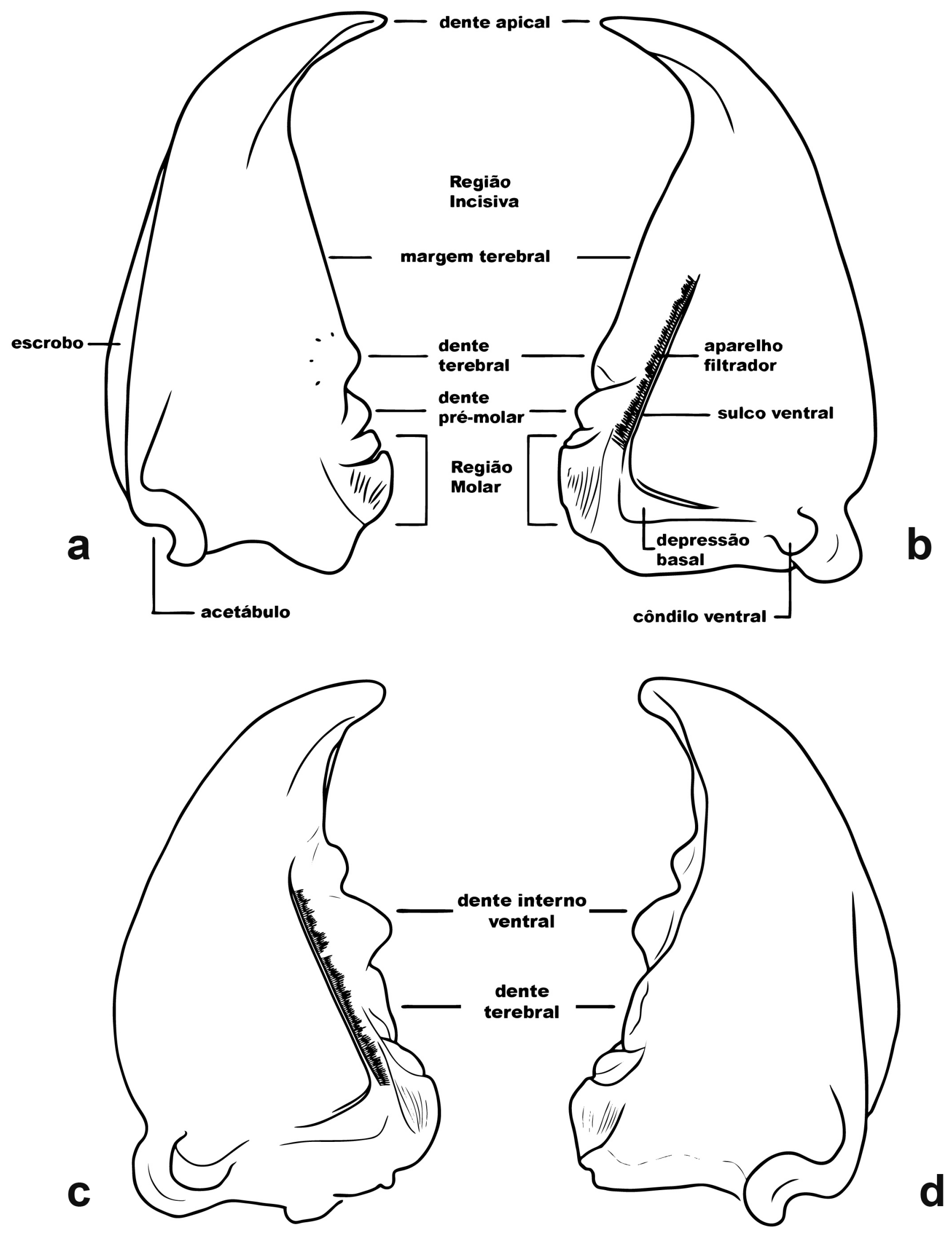

Prancha 09: Desenhos esquemáticos das mandíbulas. a. mandíbula esquerda dorsal; b. mandíbula esquerda ventral; c. mandíbula direita ventral; $\mathbf{d}$. mandíbula direita dorsal. 

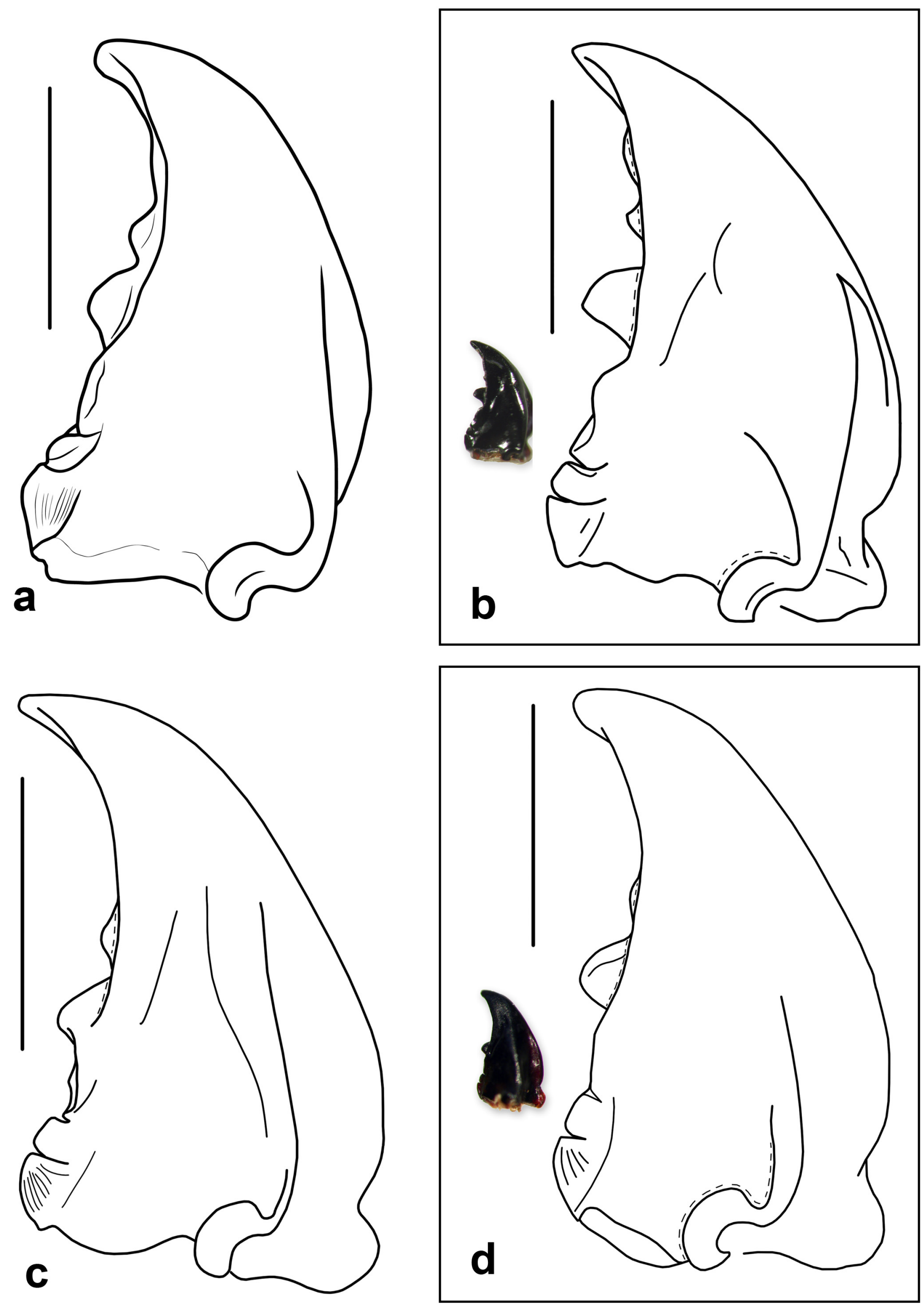

Prancha 10: Mandibula direita (dorsal). a. Morion arida; b. M. boliviensis (desenho e foto); c. $M$. brasiliensis; d. M. cordata (desenho e foto). Barras $=1 \mathrm{~mm}$ (exceto fotos). 

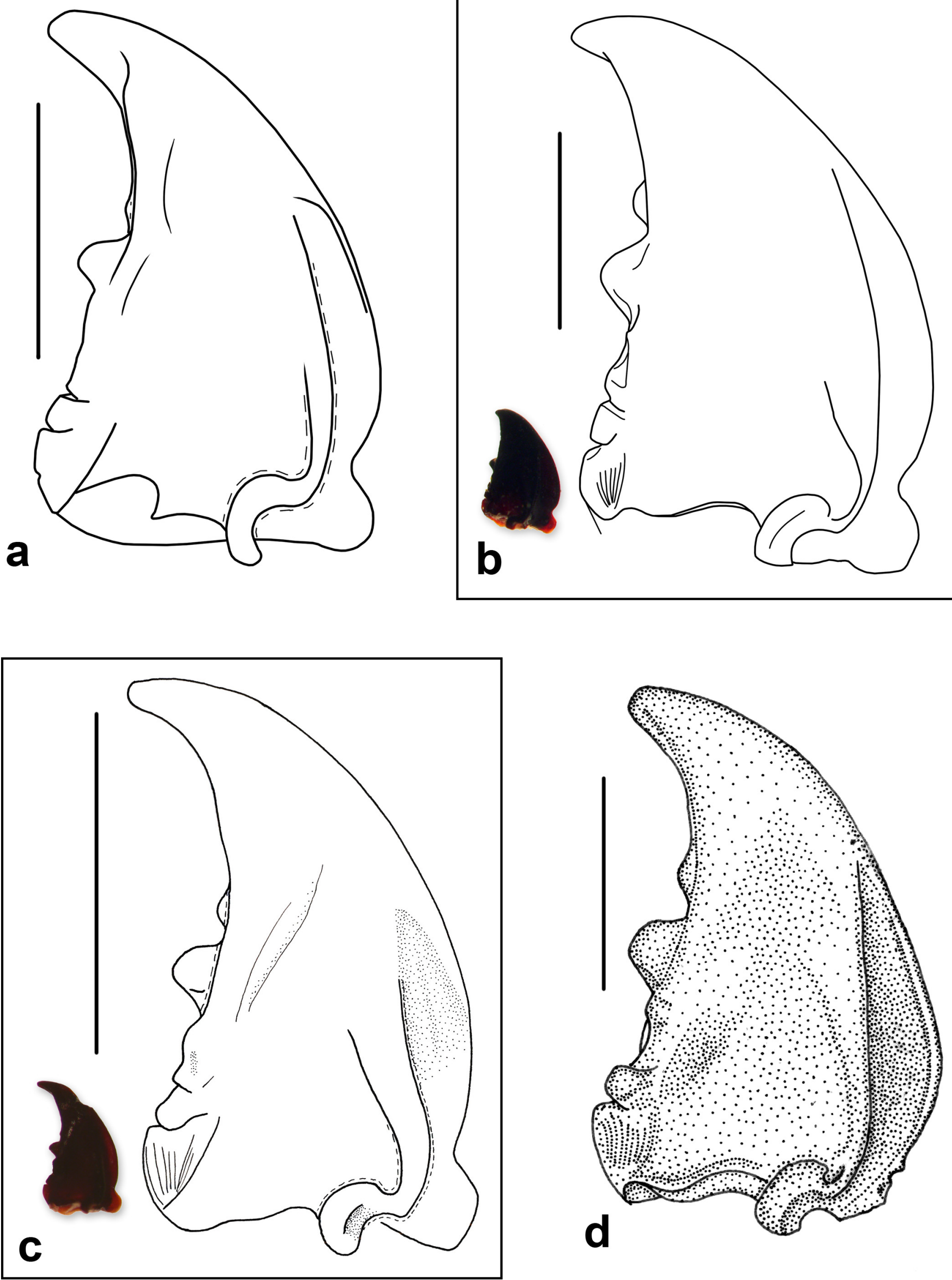

Prancha 11: Mandíbula direita (dorsal). a. Morion cycloma; b. M. lafertii (desenho e foto); c. M. monilicornis (desenho e foto); d. M. simplex. Barras $=1 \mathrm{~mm}$ (exceto fotos). 

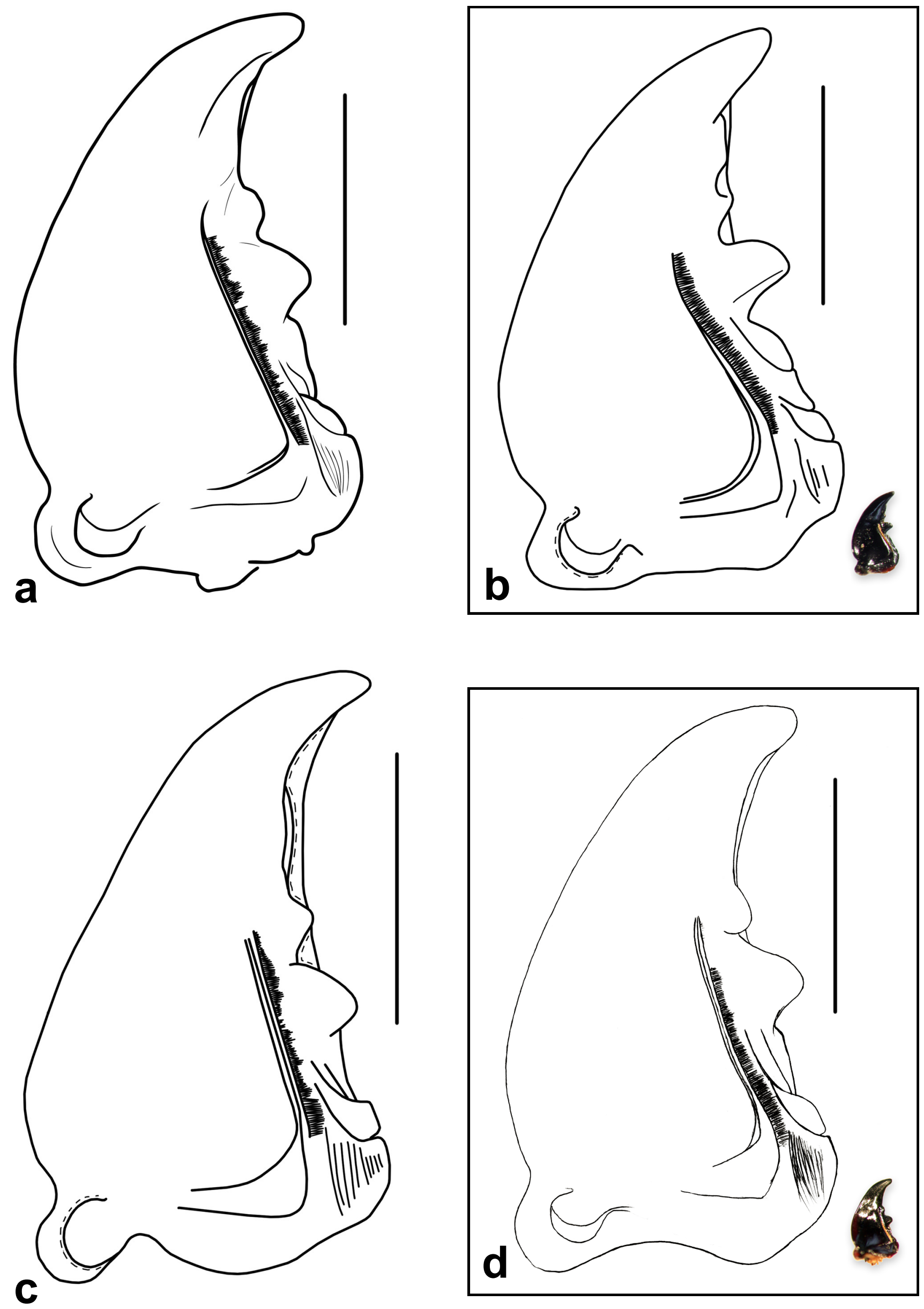

Prancha 12: Mandíbula direita (ventral). a. Morion arida; b. M. boliviensis (desenho e foto); c. $M$. brasiliensis; d. M. cordata (desenho e foto). Barras = $1 \mathrm{~mm}$ (exceto fotos). 

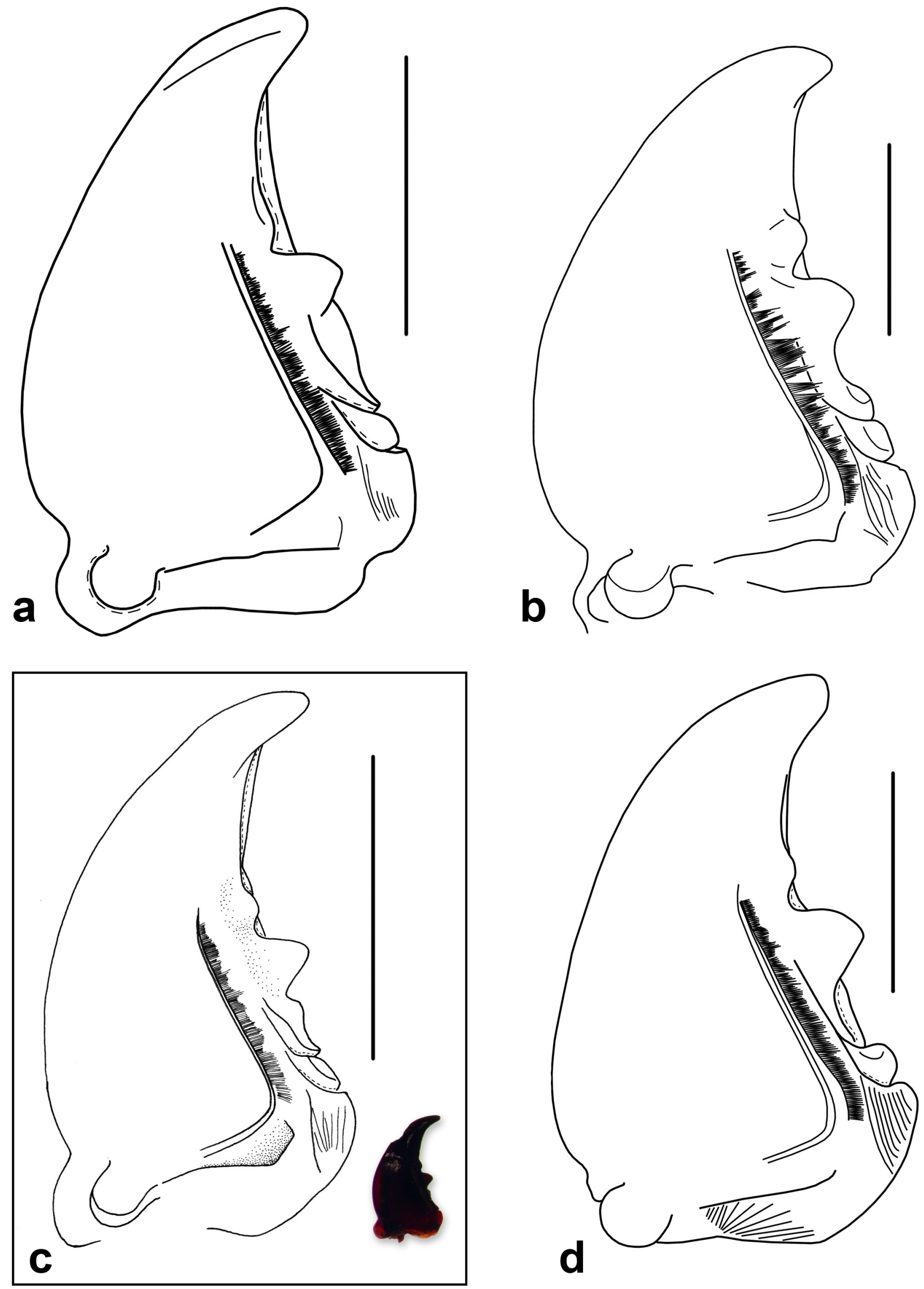

Prancha 13: Mandíbula direita (ventral). a. Morion cycloma ; b. M. lafertii; c. M. monilicornis (desenho e foto); d. M. simplex. Barras = $1 \mathrm{~mm}$ (exceto fotos). 

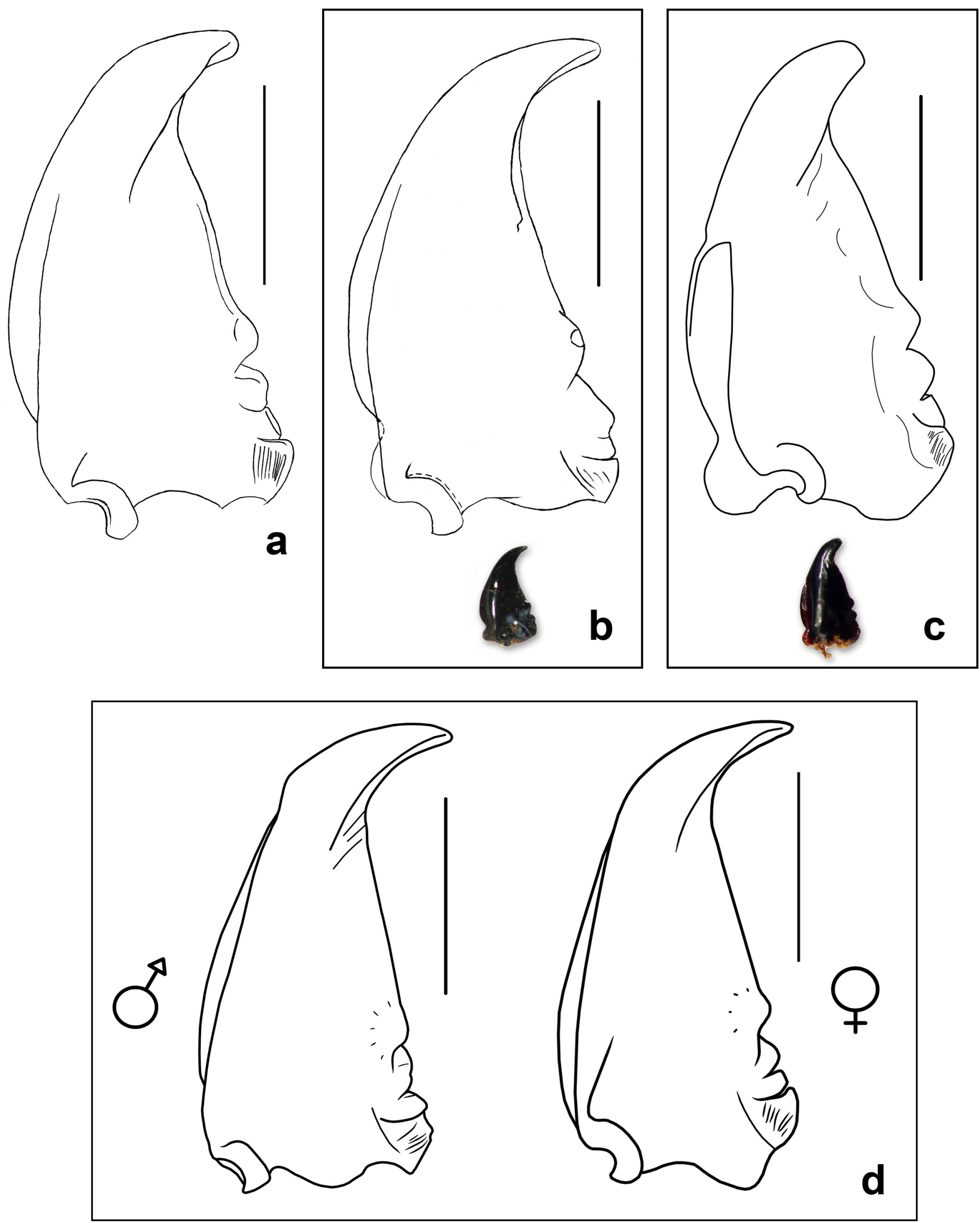

Prancha 14: Mandíbula esquerda (dorsal). a. Morion arida; b. M. boliviensis (desenho e foto); c. $M$. cordata (desenho e foto); d. M. brasiliensis (macho e fêmea). Barras $=1 \mathrm{~mm}$ (exceto fotos). 

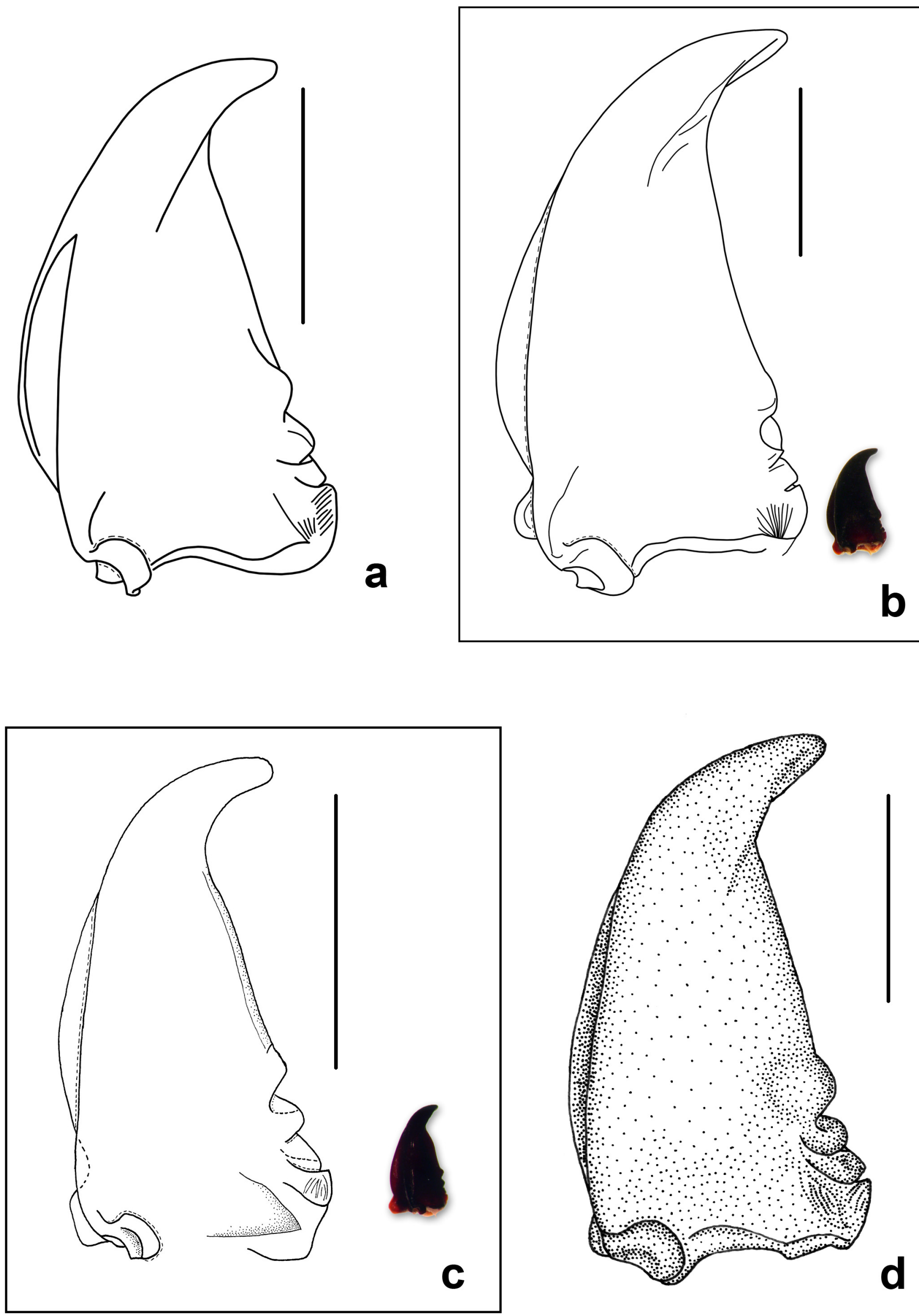

Prancha 15: Mandíbula esquerda (dorsal). a. Morion cycloma; b. M. lafertii (desenho e foto); c. $M$. monilicornis (desenho e foto); d. $M$. simplex. Barras $=1 \mathrm{~mm}$ (exceto fotos). 

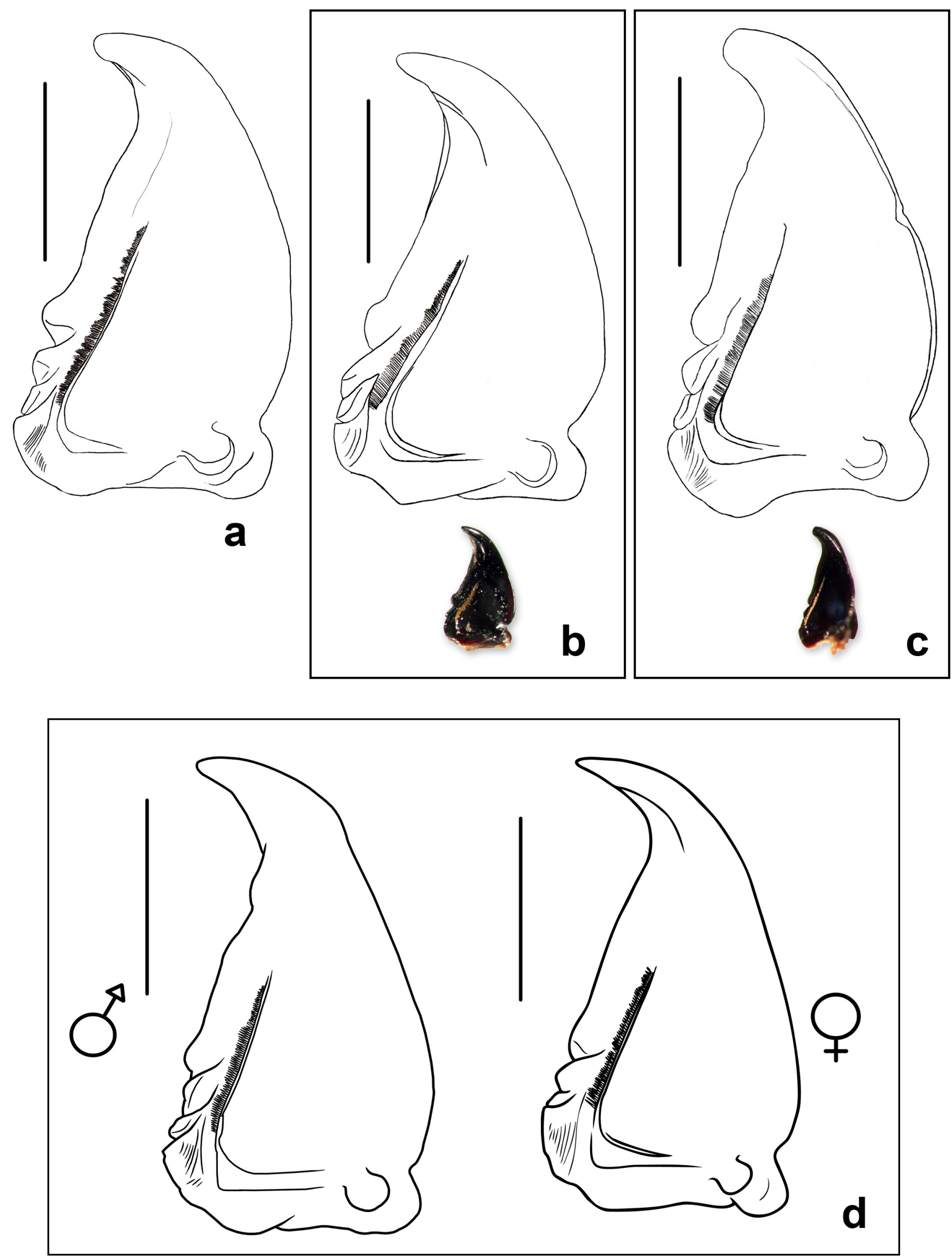

Prancha 16: Mandíbula esquerda (ventral). a. Morion arida; b. $M$. boliviensis (desenho e foto); c. $M$. cordata (desenho e foto); d. M. brasiliensis (macho e fêmea). Barras = $1 \mathrm{~mm}$ (exceto fotos). 

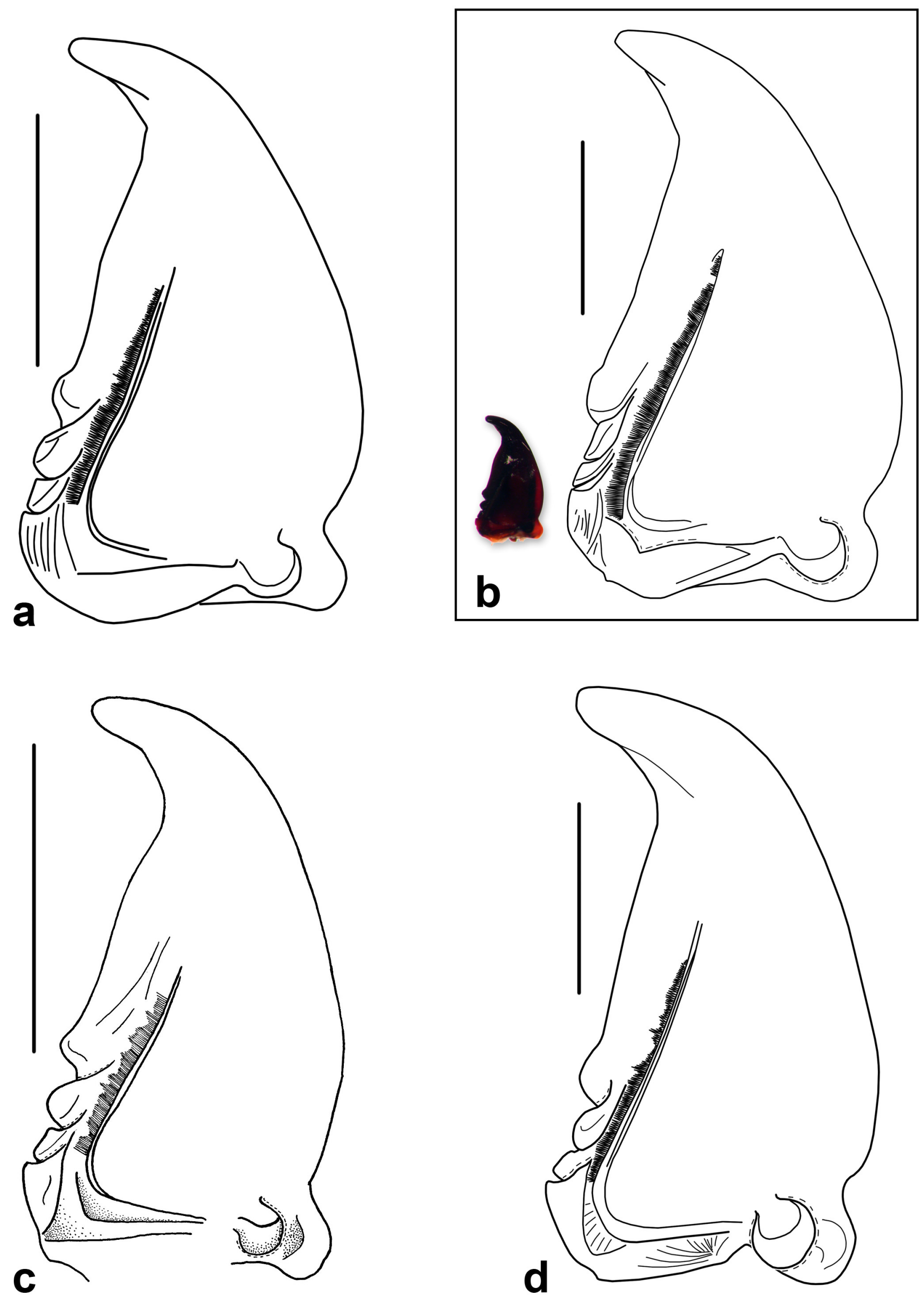

Prancha 17: Mandíbula esquerda (ventral). a. Morion cycloma; b. $M$. lafertii (desenho e foto); c. $M$. monilicornis; d. M. simplex. Barras $=1 \mathrm{~mm}$ (exceto fotos). 

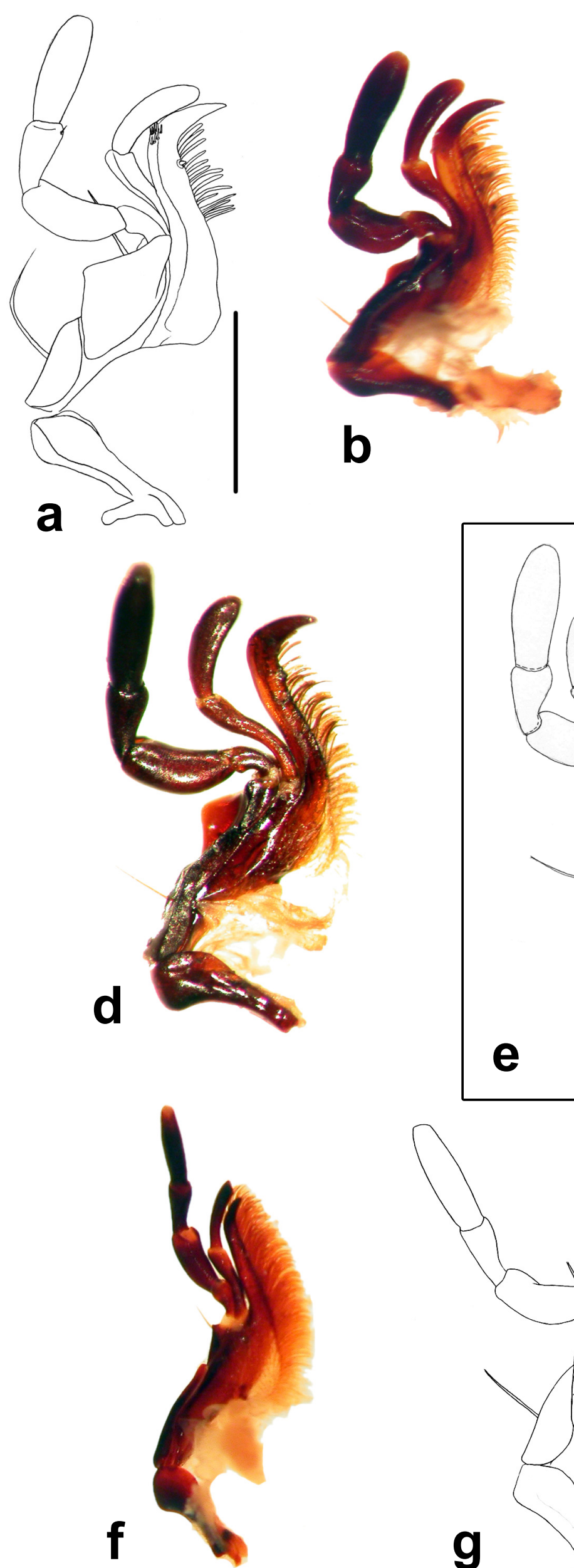
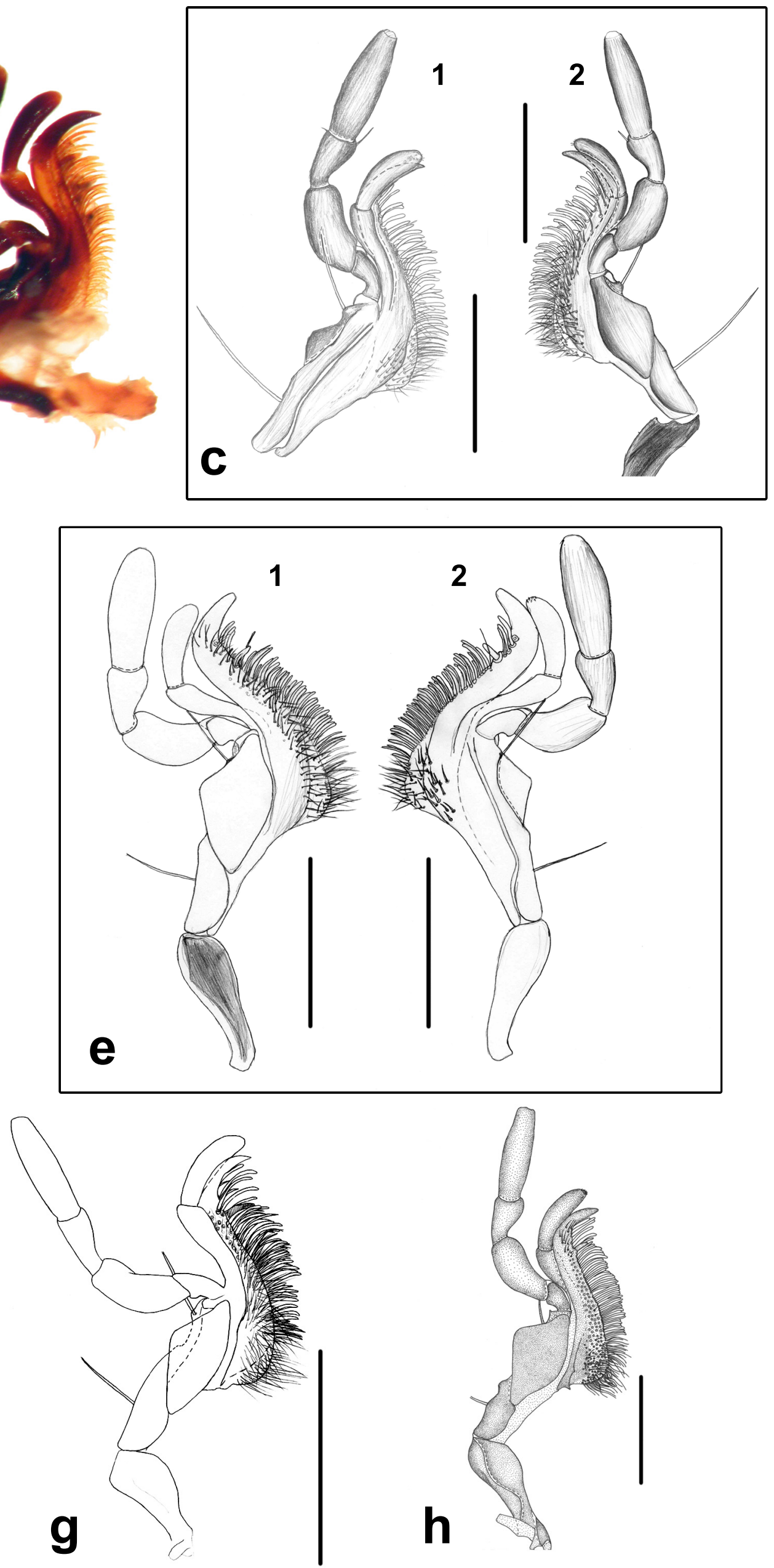

Prancha 18: Maxilas. a. Morion arida (dorsal) (cerdas marginais parcialmente representadas); b. $M$. boliviensis (ventral); c. M. brasiliensis (1. ventral (cardo não representado); 2 . dorsal (cardo parcialmente representado)); d. M. cordata (ventral); e. M. cycloma (1. dorsal; 2. ventral); f. M. lafertii (ventral); g. M. monilicornis (dorsal); h. M. simplex (dorsal). Barras $=1 \mathrm{~mm}$. 

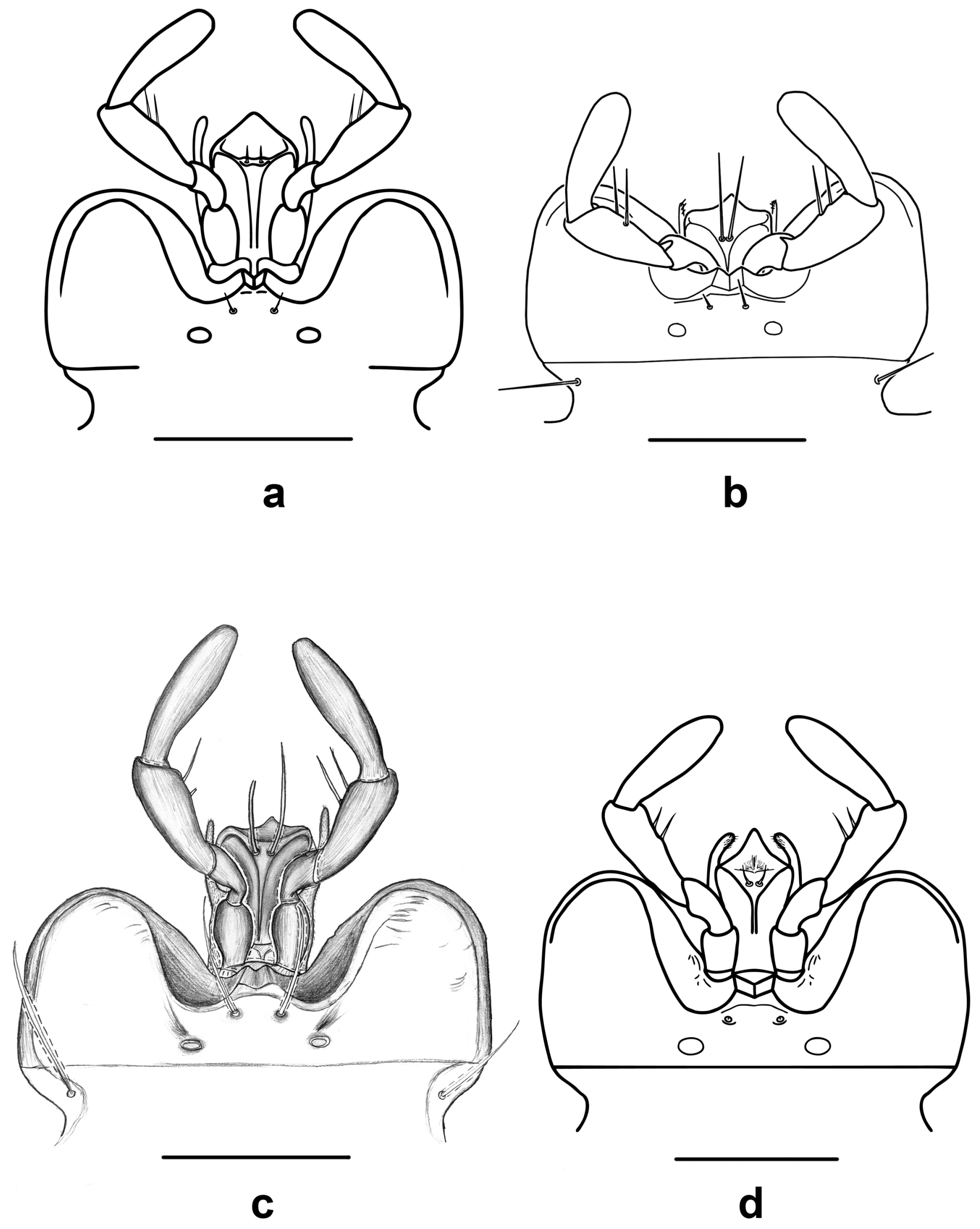

Prancha 19: Lábio. a. Morion arida; b. M. boliviensis (lígula retraída); c. M. brasiliensis; d. M. cordata. Barras $=1 \mathrm{~mm}$. 


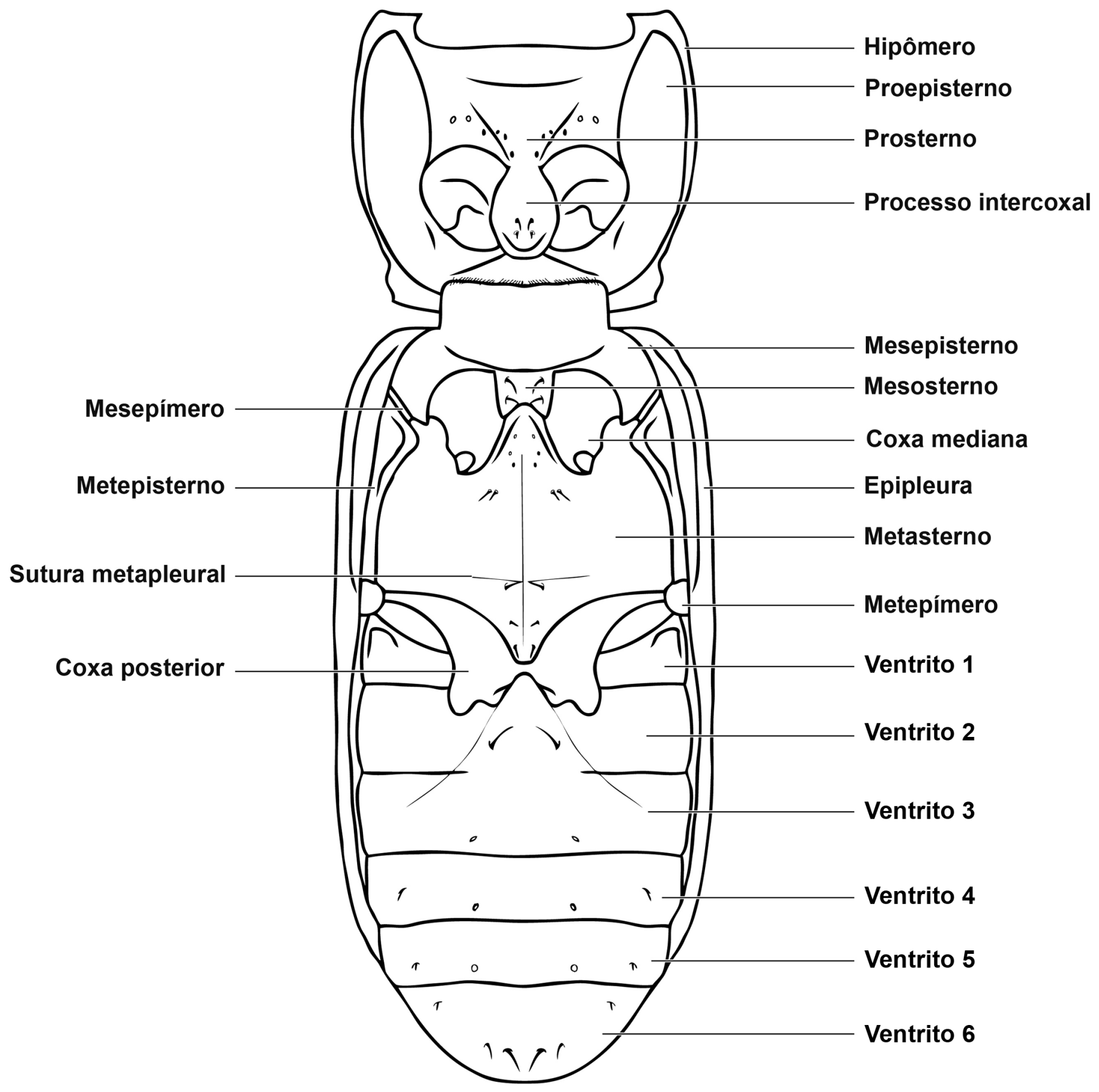

Prancha 20: Desenho esquemático da vista ventral de Morion (pernas e cabeça não representadas). 

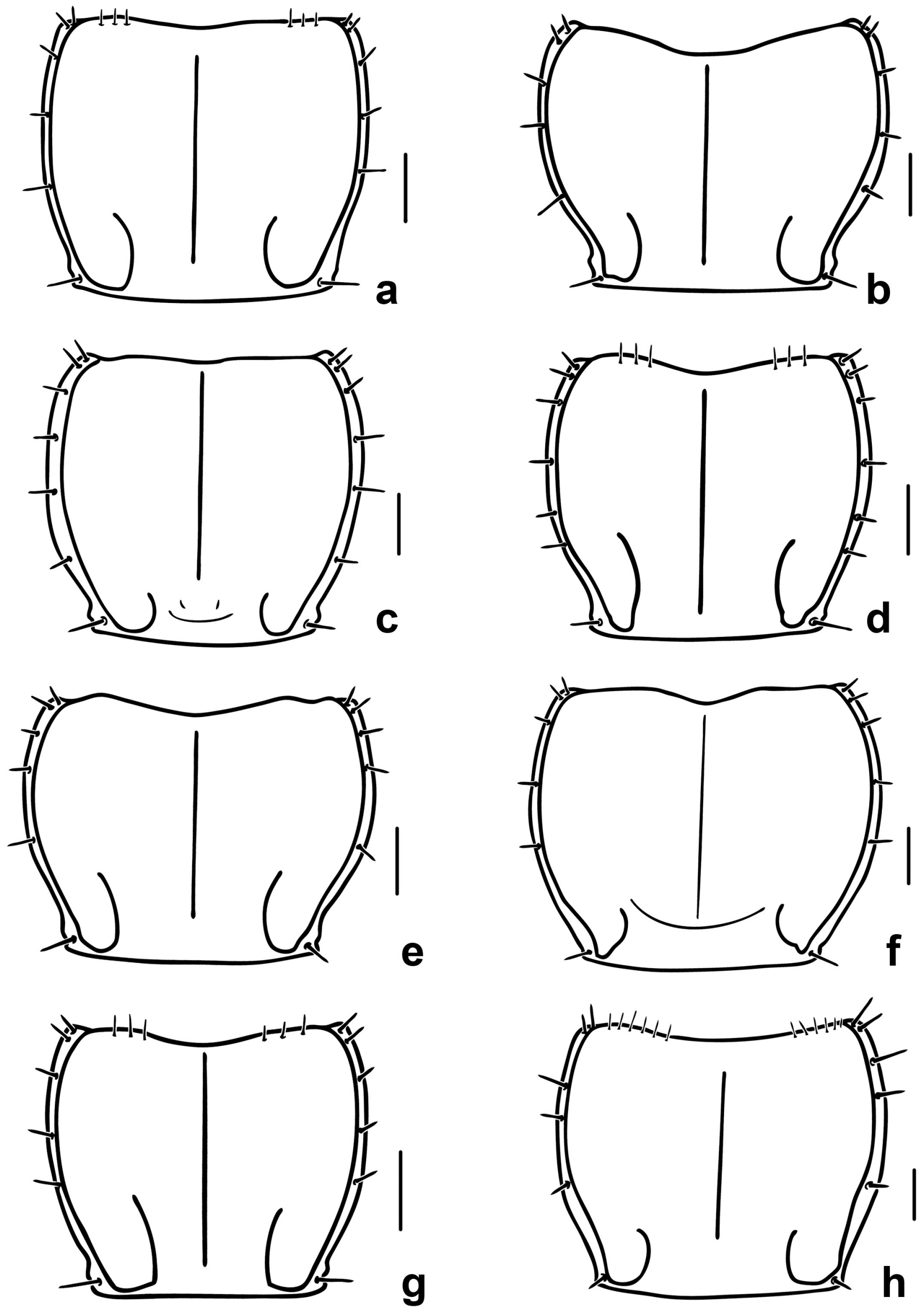

Prancha 21: Pronoto. a. Morion arida; b. M. boliviensis; c. M. brasiliensis; d. M. cordata; e. M. cycloma; f. M. lafertii; g. M. monilicornis; h. M. simplex. Barras = $1 \mathrm{~mm}$. 

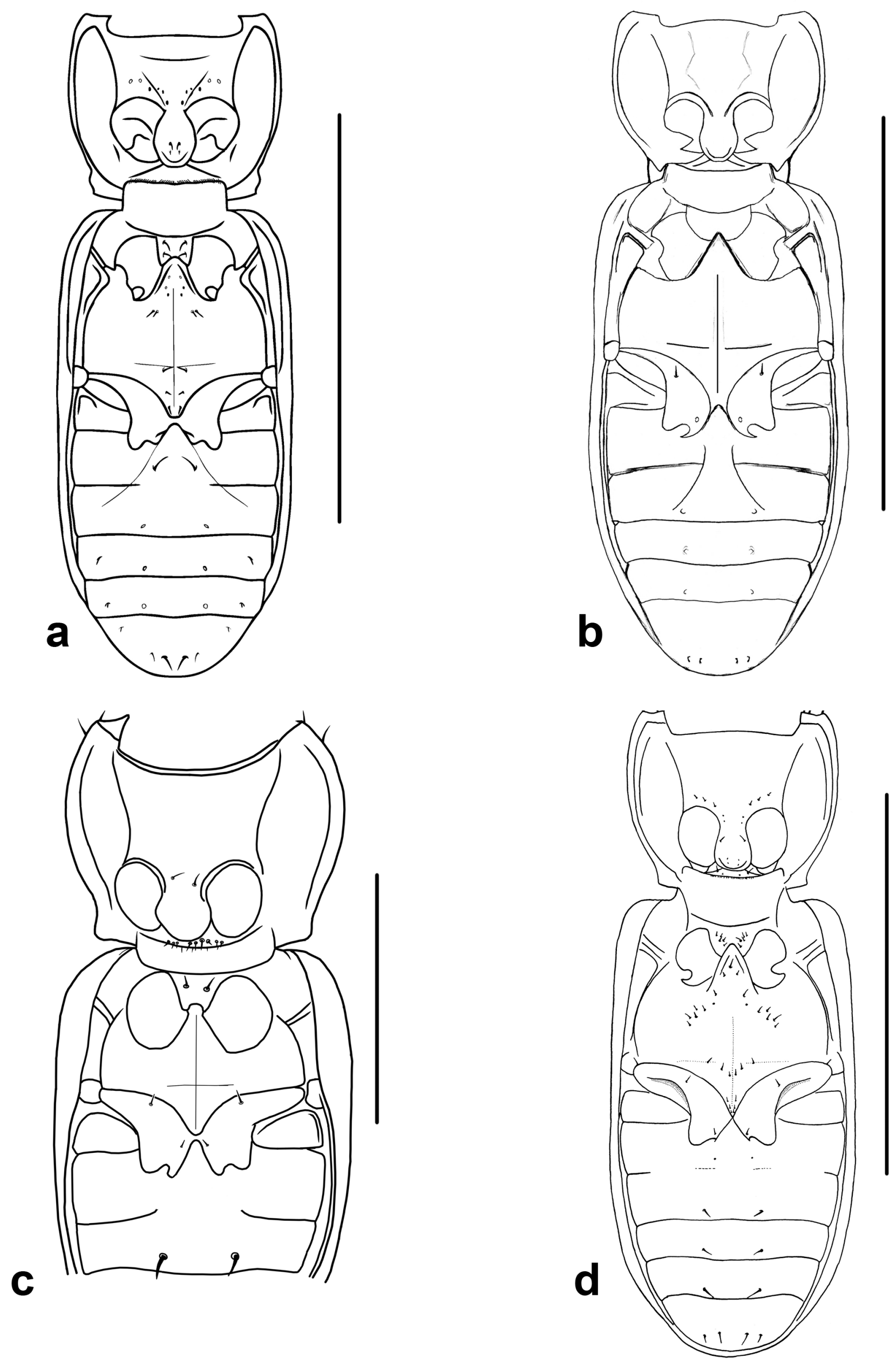

Prancha 22: Tórax e abdômen (ventral) (pernas não representadas). a. Morion arida; b. M. boliviensis; c. $M$. brasiliensis (ventritos 4, 5 e 6 não representados); d. $M$. cordata. Barras $=10 \mathrm{~mm}$, exceto em c $=5 \mathrm{~mm}$. 

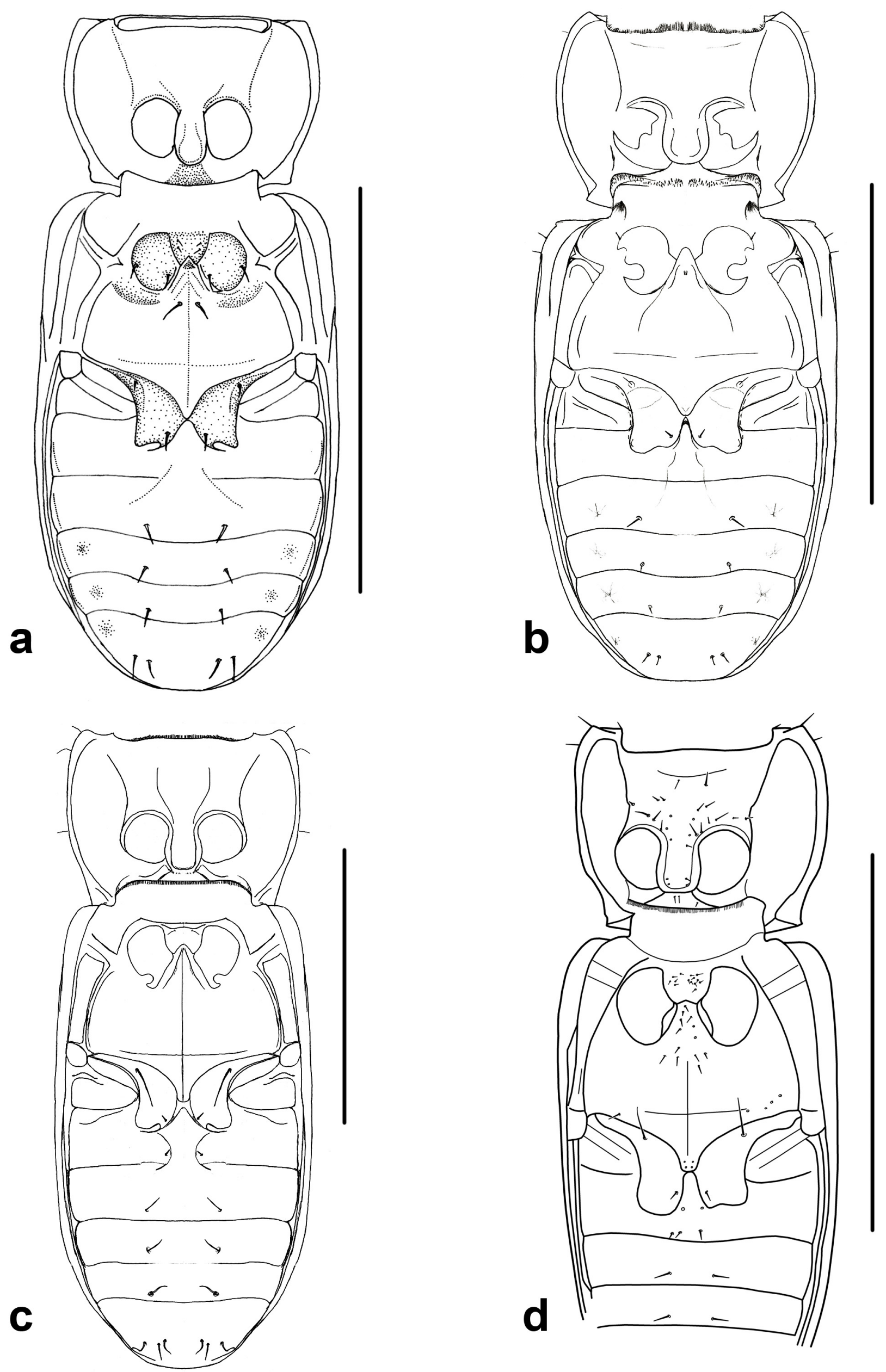

Prancha 23: Tórax e abdômen (ventral) (pernas não representadas). a. Morion cycloma; b. M. lafertii; c. $M$. monilicornis; d. $M$. simplex (ventritos 5 e 6 não estão representados). Fig. a, d, barras $=10 \mathrm{~mm}$; fig. $\mathbf{b}, \mathbf{c}$, barras $=5 \mathrm{~mm}$. 

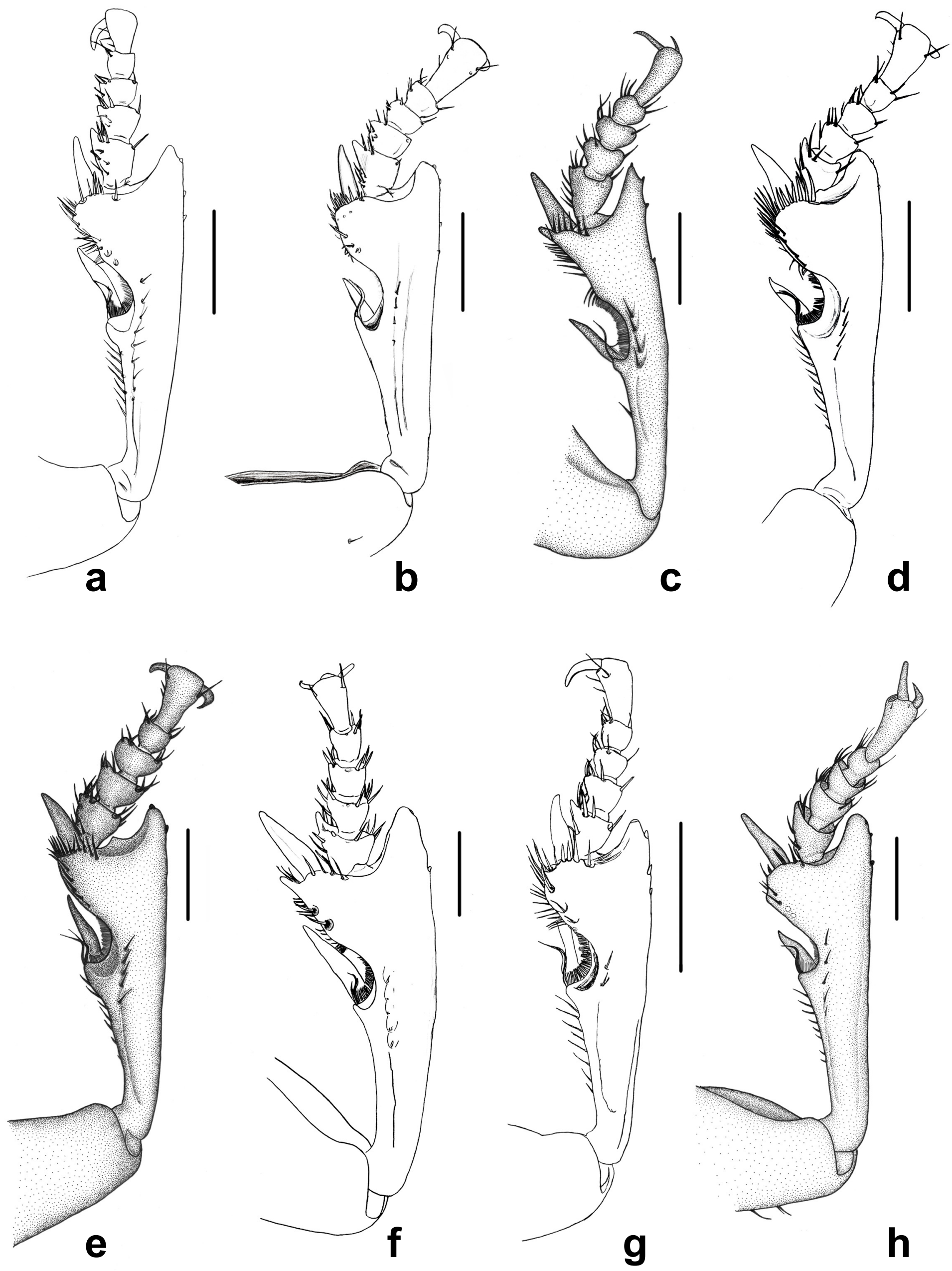

Prancha 24: Perna anterior (dorsal) (apenas o tarso, tíbia e parte distal do fêmur estão representados). a. Morion arida; b. M. boliviensis; c. M. brasiliensis; d. M. cordata; e. M. cycloma; f. M. lafertii; g. M. monilicornis; h. M. simplex. Barras $=1 \mathrm{~mm}$. 

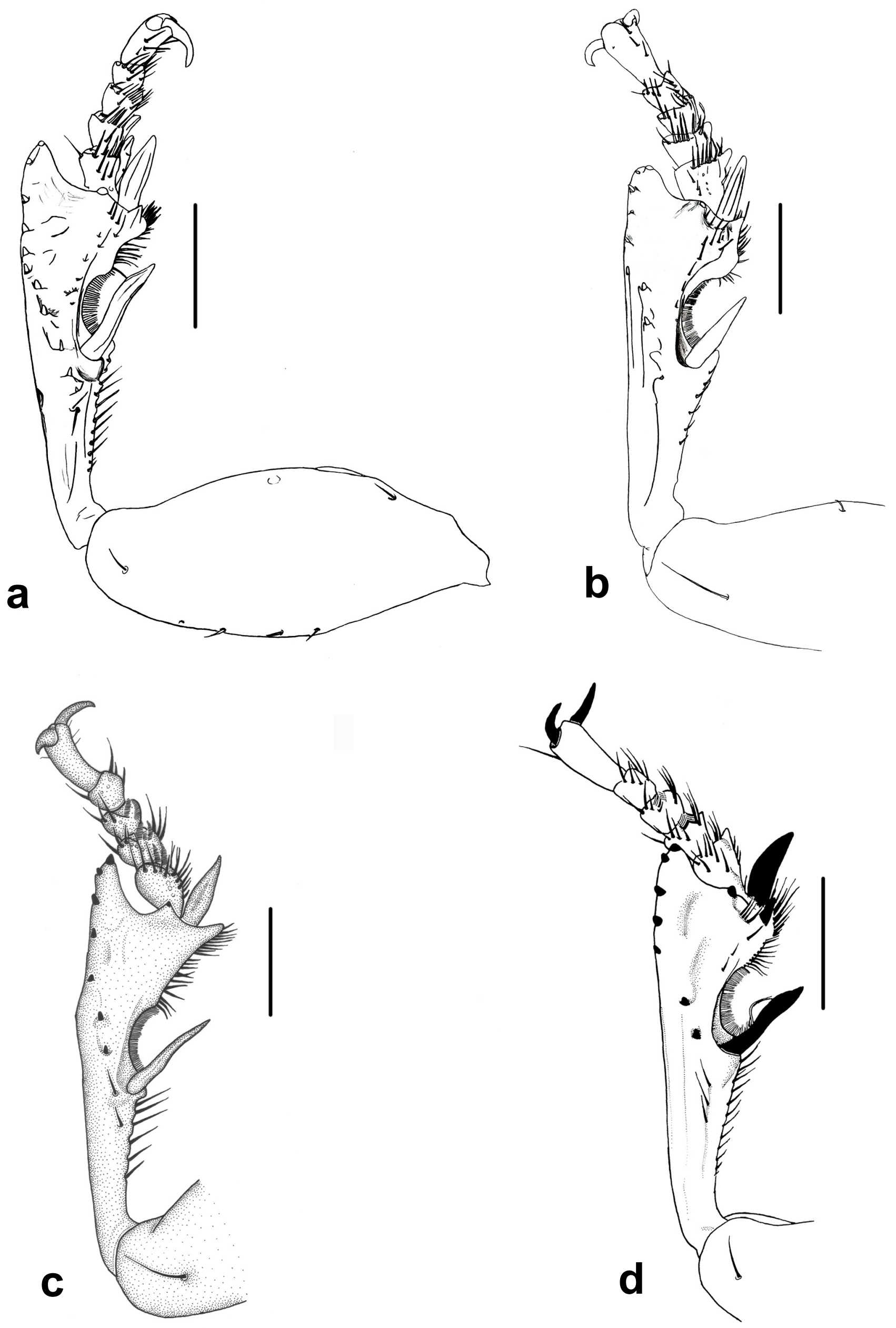

Prancha 25: Perna anterior (ventral) (apenas o tarso, tíbia e parte posterior do fêmur estão representados; em a o fêmur está completo). a. Morion arida; b. M. boliviensis; c. M. brasiliensis; d. $M$. cordata. Barras $=1 \mathrm{~mm}$. 

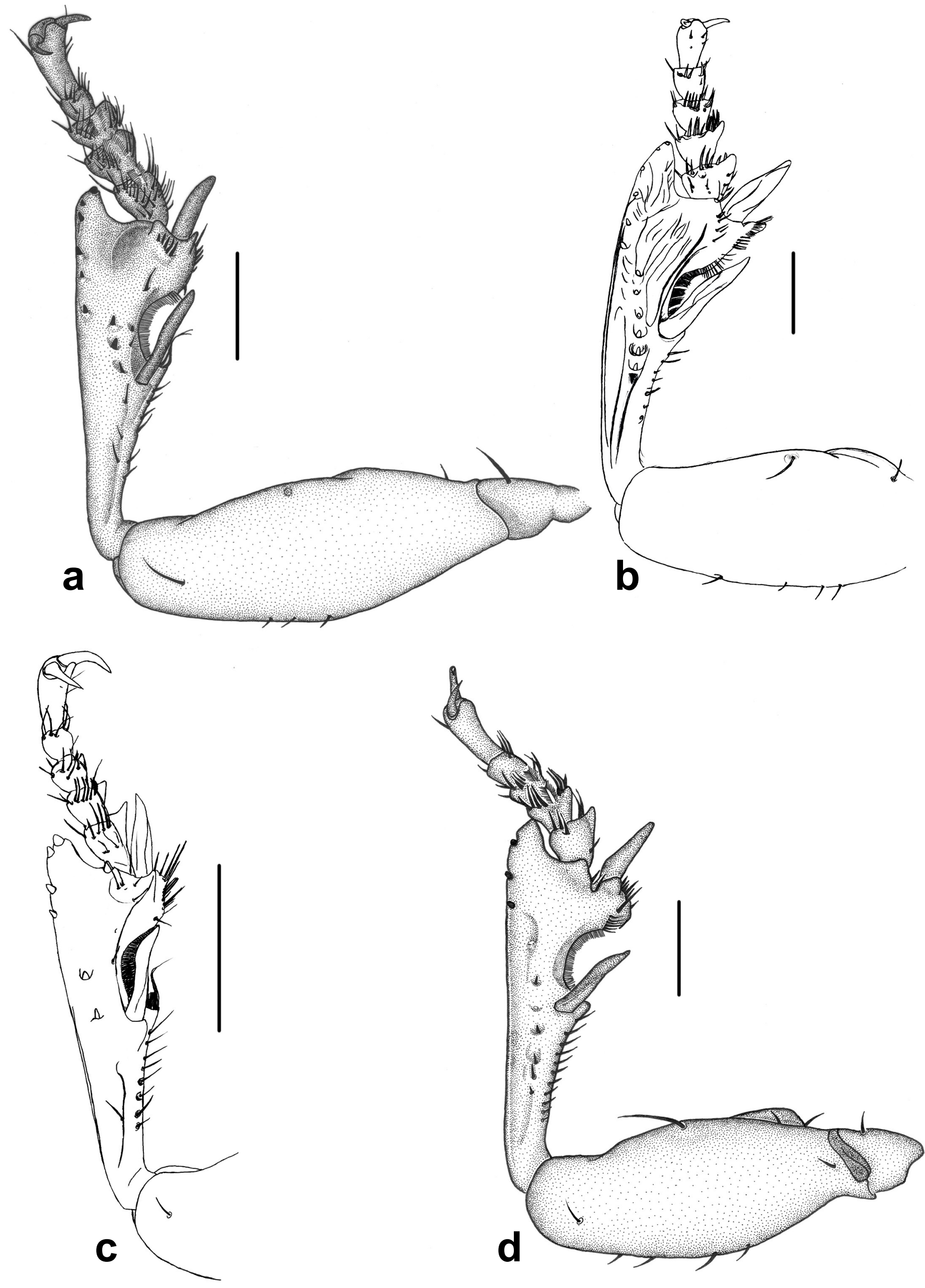

Prancha 26: Perna anterior (ventral). a. Morion cycloma; b. M. lafertii (coxa e base do fêmur não representados); c. M. monilicornis (apenas o tarso, tíbia e ápice do fêmur estão representados); $\mathbf{d}$. 

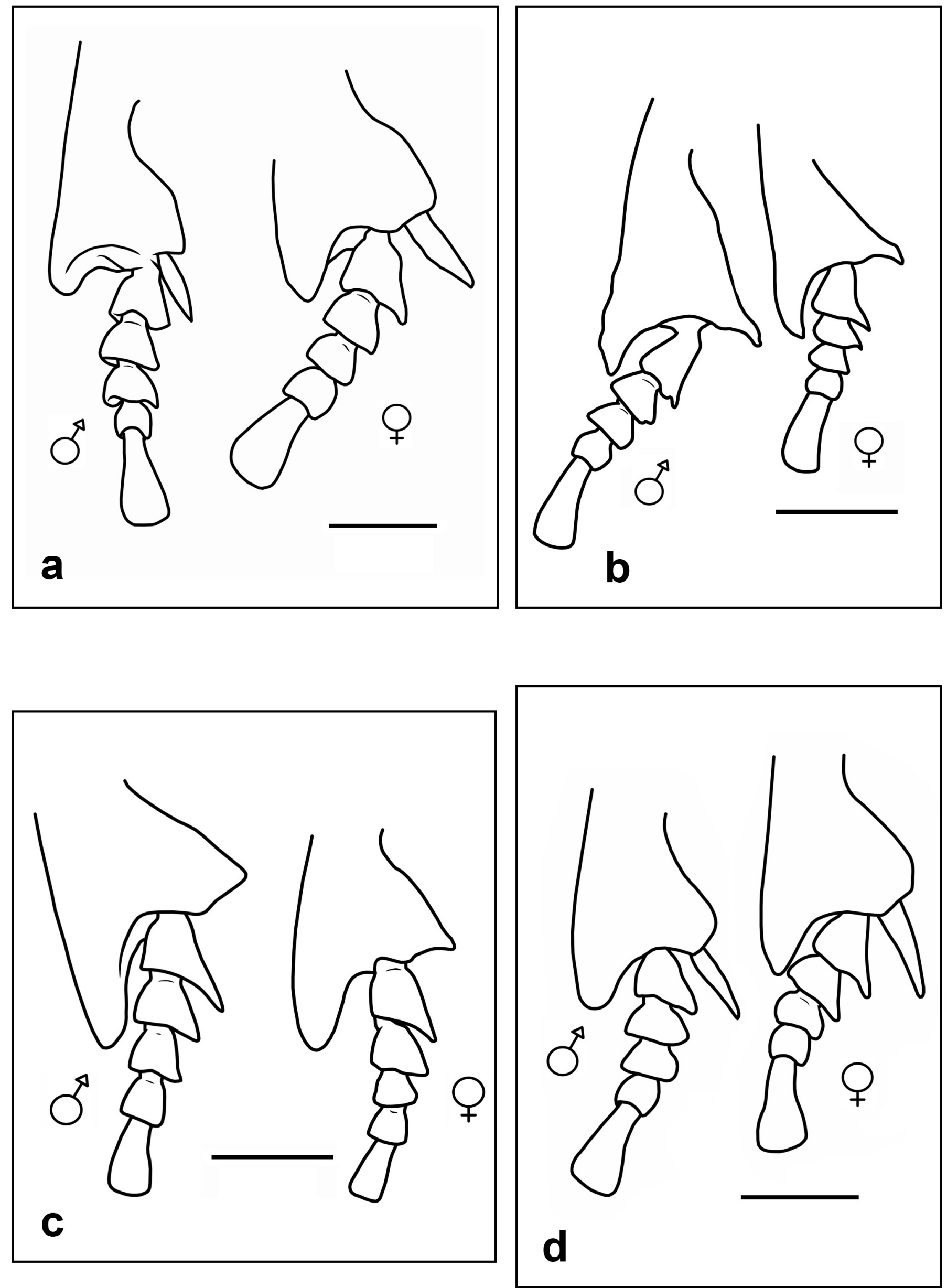

Prancha 27: Perna anterior - ápice da tíbia e tarso (as garras não estão representadas). a. Morion boliviensis; b. M. brasiliensis; c. M. lafertii; d. M. simplex. Barras $=1 \mathrm{~mm}$. 

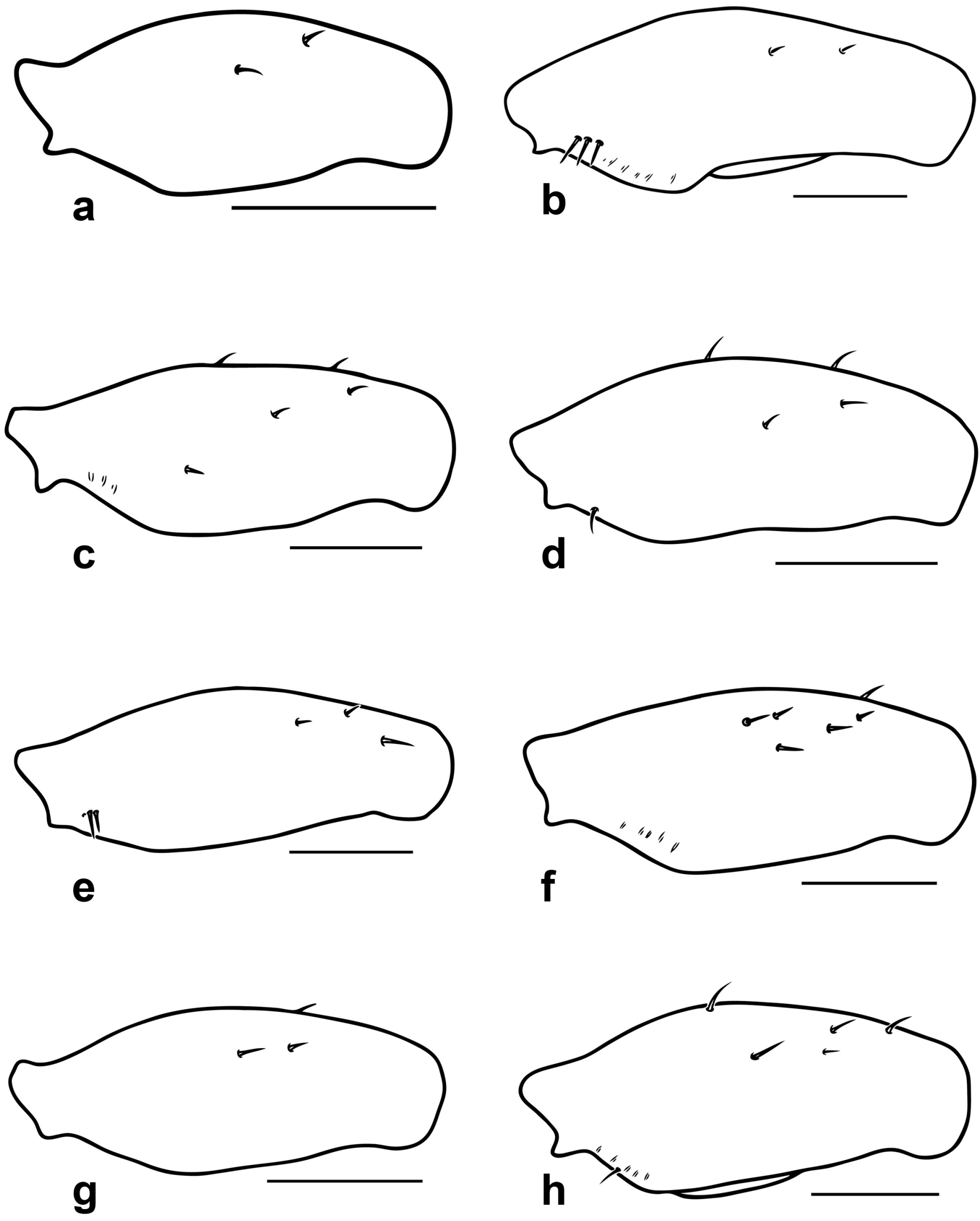

Prancha 28: Fêmur anterior - vista lateral interna. a. Morion arida; b. M. boliviensis; c. M. brasiliensis; $\mathbf{d}$. M. cordata; e. M. cycloma; f. M. lafertii; g. M. monilicornis; h. M. simplex. Barras $=1 \mathrm{~mm}$. 

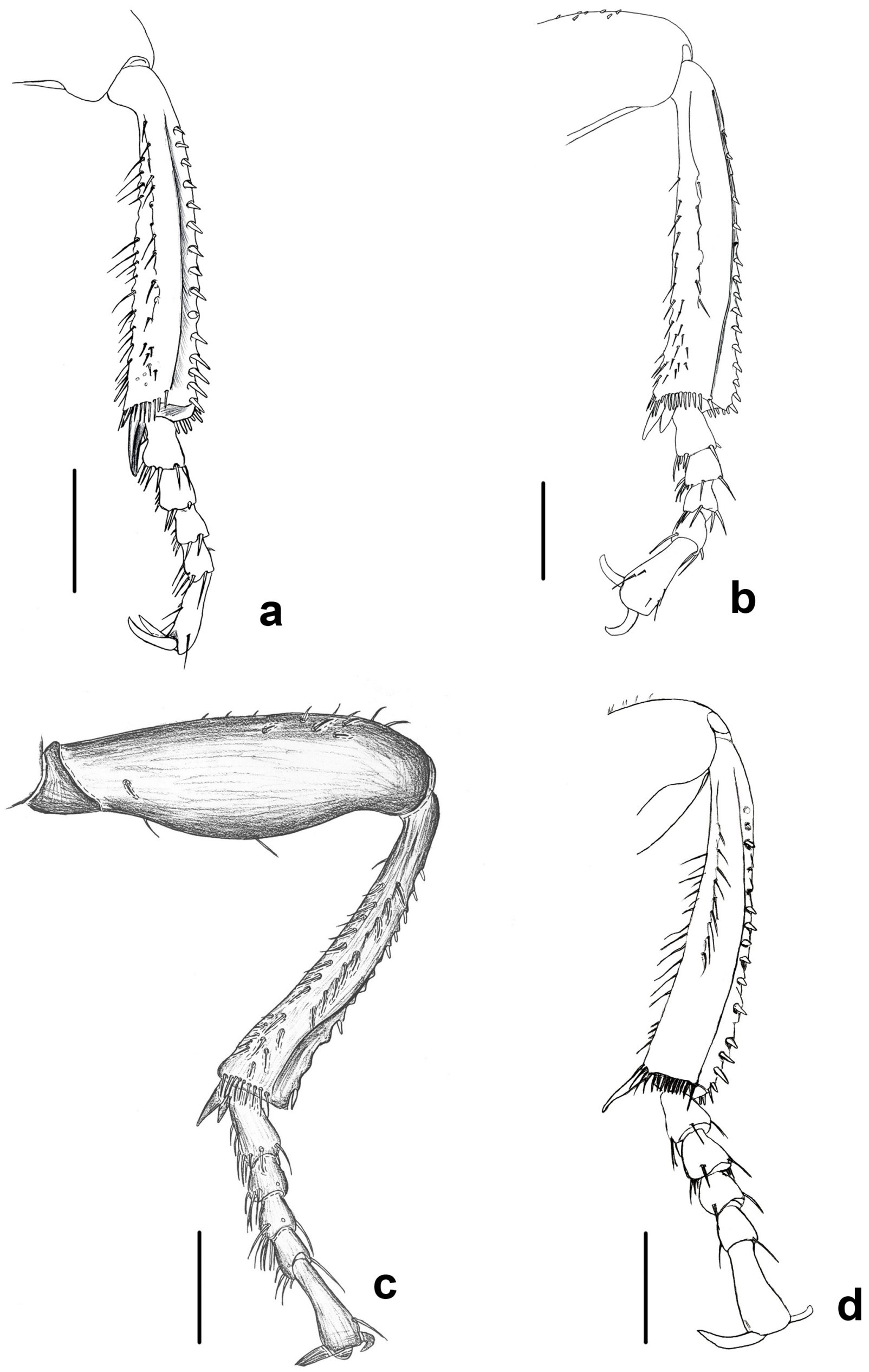

Prancha 29: Perna mediana (dorsal). a. Morion arida; b. M. boliviensis; c. M. brasiliensis; d. M. cordata. Fig. a, b, d apenas o tarso, tíbia e parte posterior do fêmur estão representados. Barras $=1 \mathrm{~mm}$. 


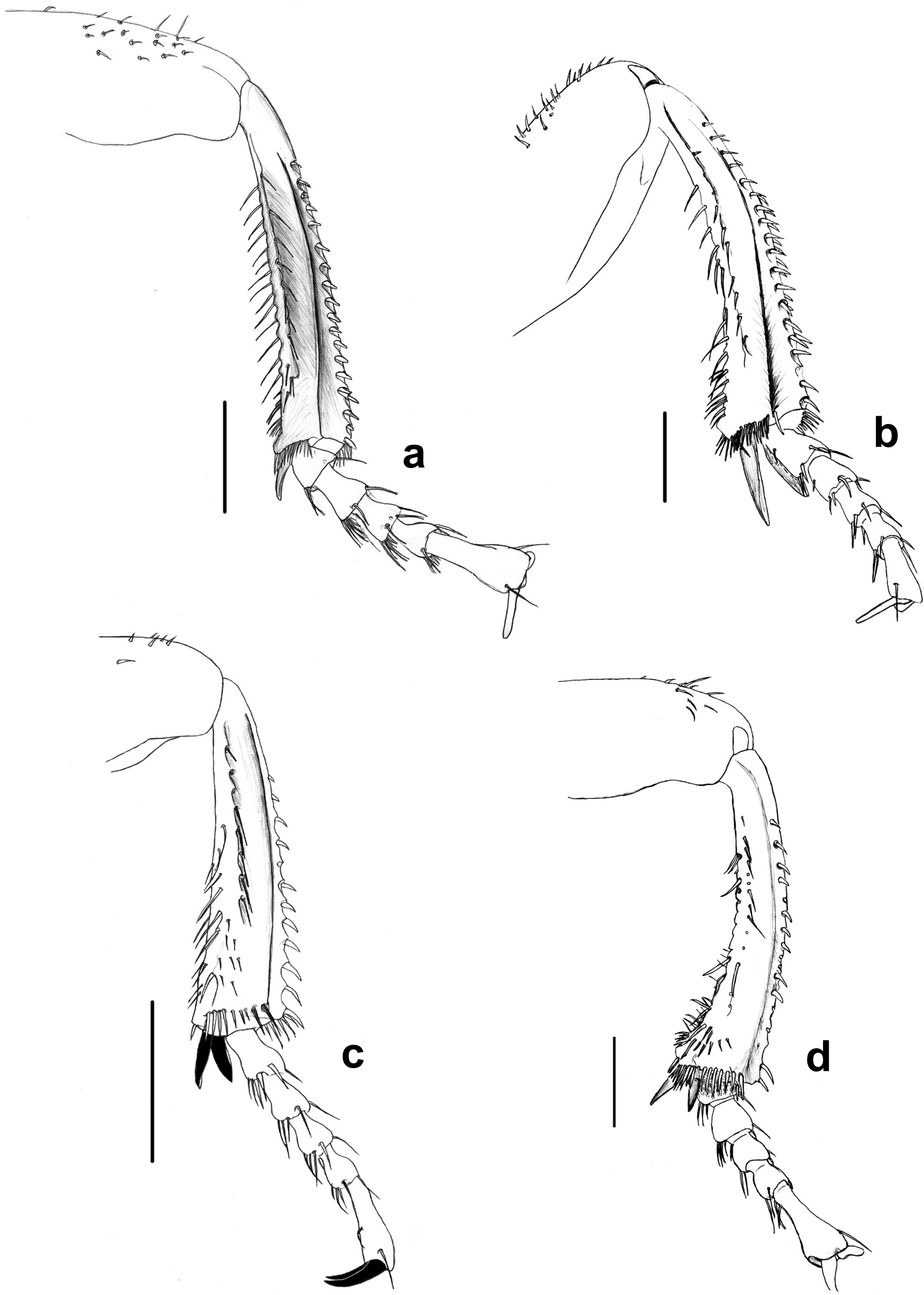

Prancha 30: Perna mediana (dorsal) (apenas o tarso, tíbia e parte posterior do fêmur estão representados). a. Morion cycloma; b. M. lafertii; c. M. monilicornis; d. M. simplex. Barras $=1 \mathrm{~mm}$. 

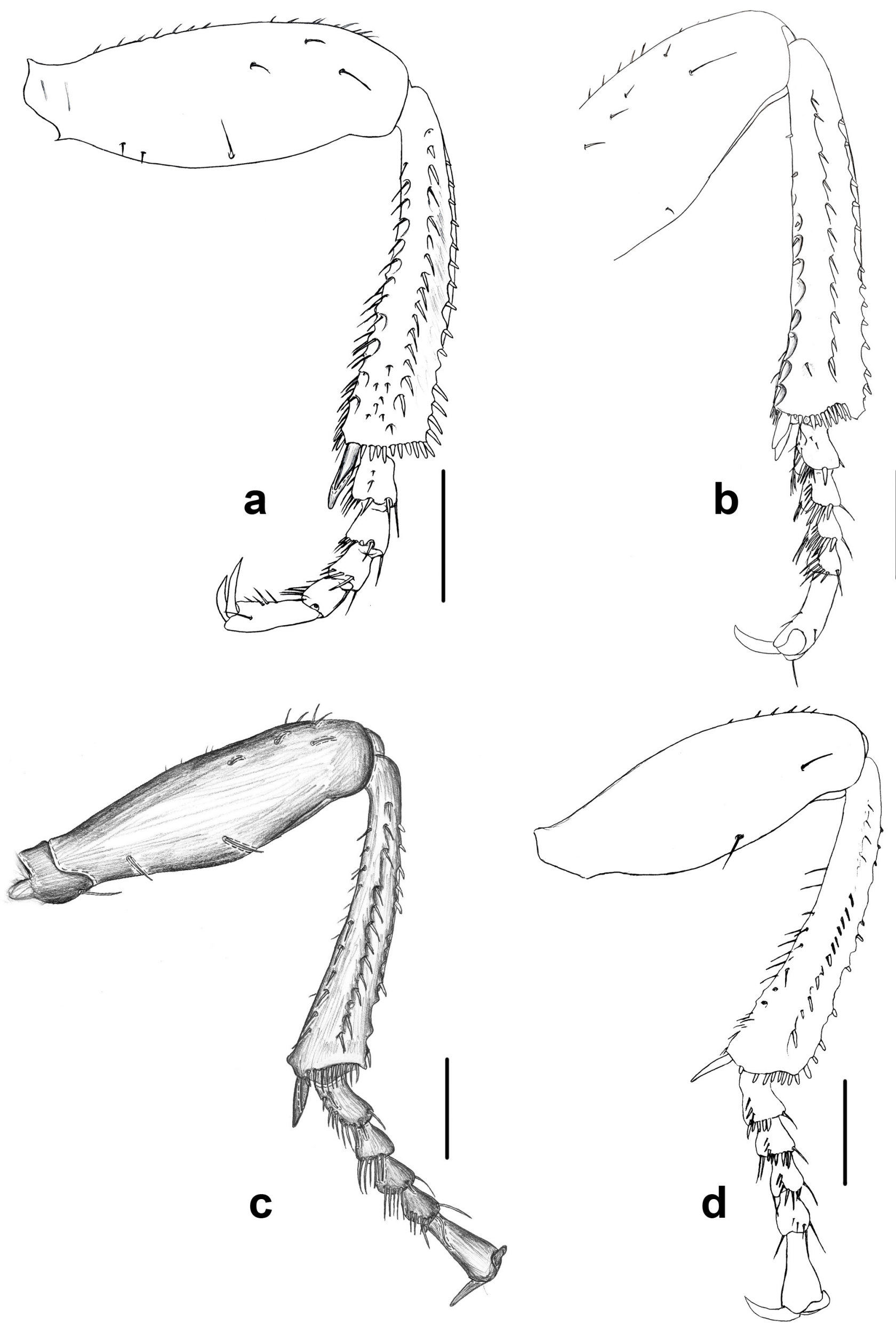

Prancha 31: Perna mediana (ventral). Fig. a,d, o trocânter e fig. b, o trocânter e parte basal do fêmur não foram representados. a. Morion arida; b. $M$. boliviensis; $\mathbf{c}$. $M$. brasiliensis; $\mathbf{d}$. $M$. cordata. Barras = $1 \mathrm{~mm}$. 

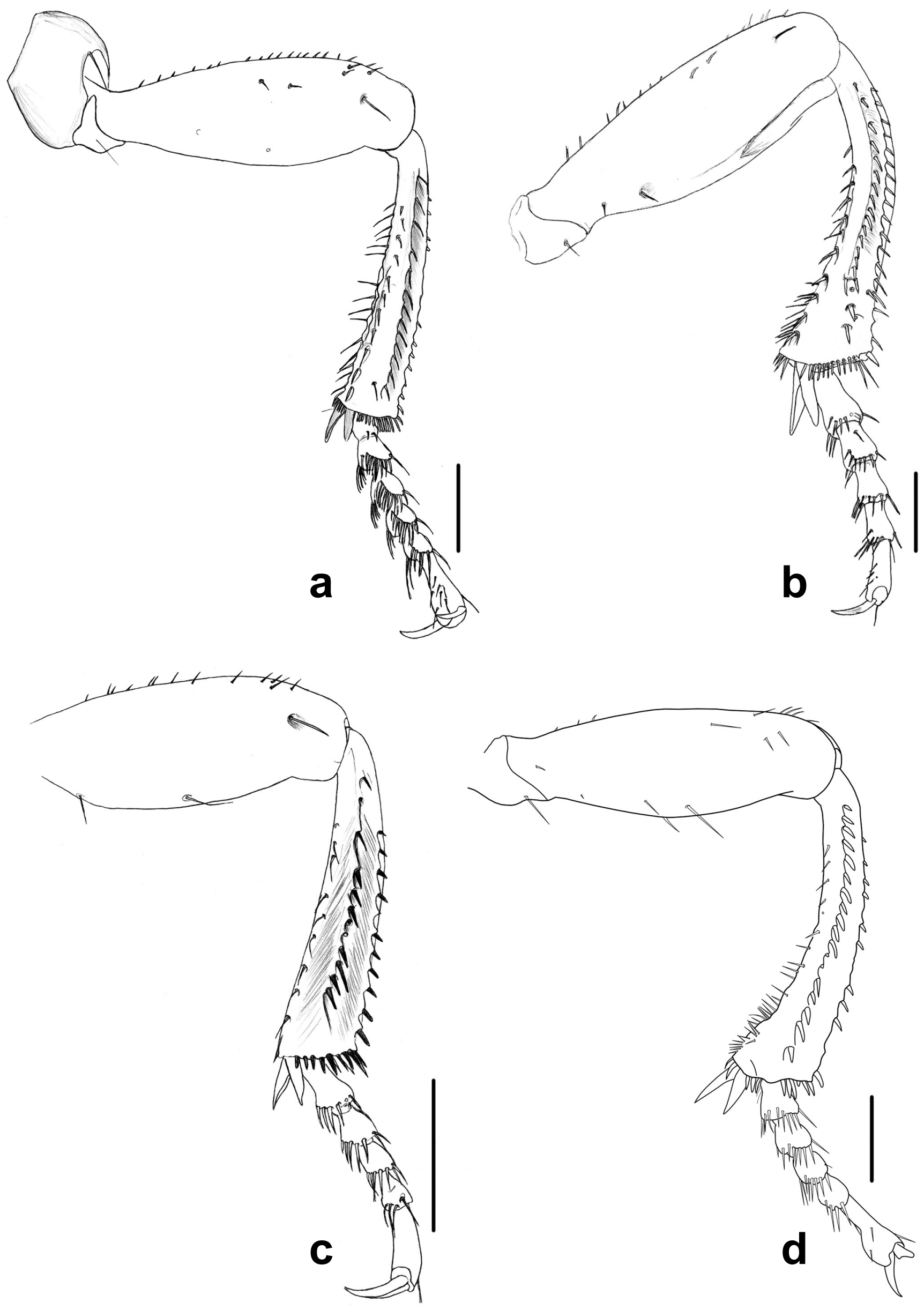

Prancha 32: Perna mediana (ventral). (Em a, a coxa também foi representada; em c, falta o trocânter). a. Morion cycloma; b. M. lafertii; c. M. monilicornis; d. M. simplex. Barras $=1 \mathrm{~mm}$. 

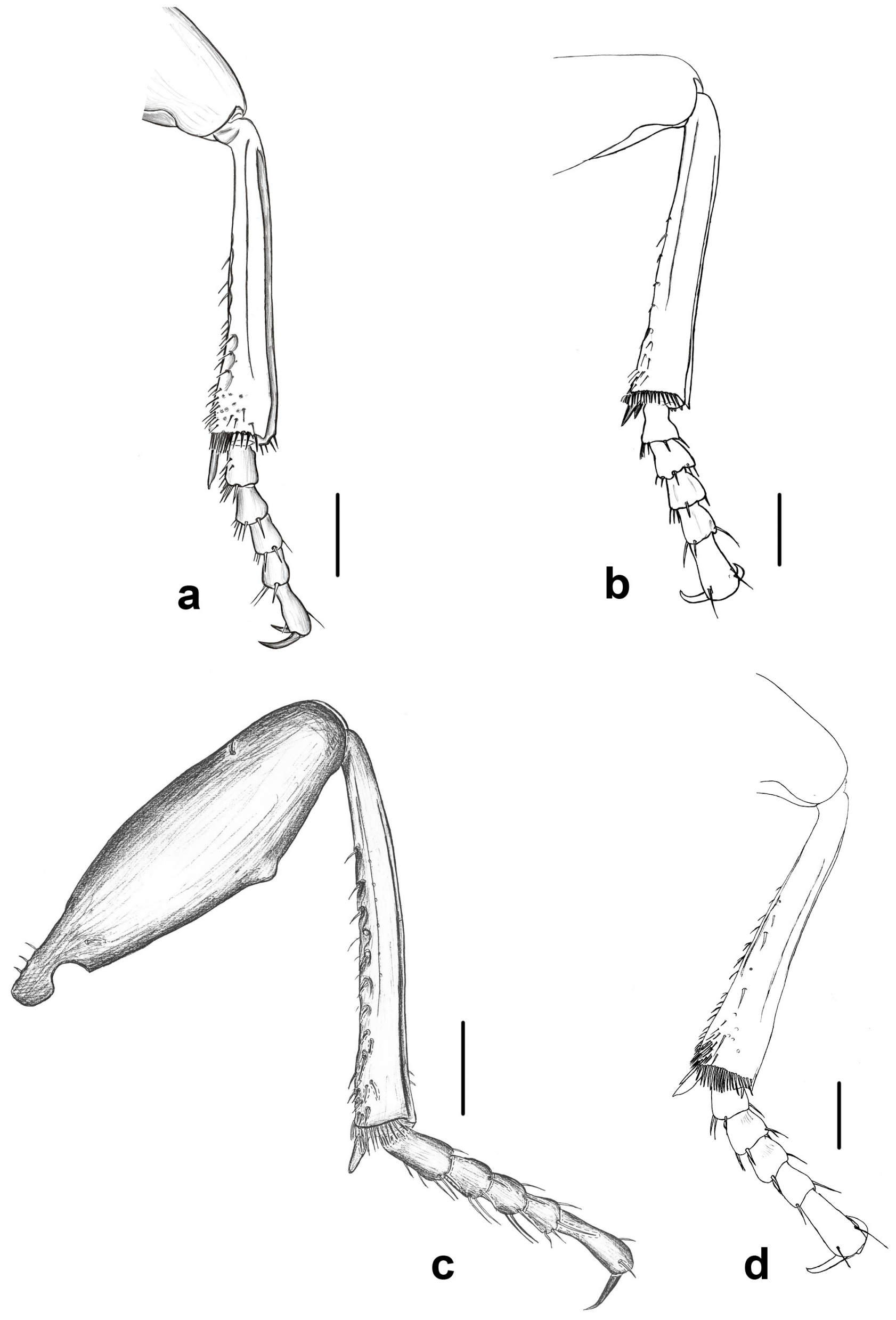

Prancha 33: Perna posterior (dorsal). (Apenas o tarso, tíbia e parte posterior do fêmur estão representados, exceto em c, onde o fêmur está completo).a. Morion arida; b. M. boliviensis; c. M. brasiliensis; d. $M$. cordata. Barras $=1 \mathrm{~mm}$. 

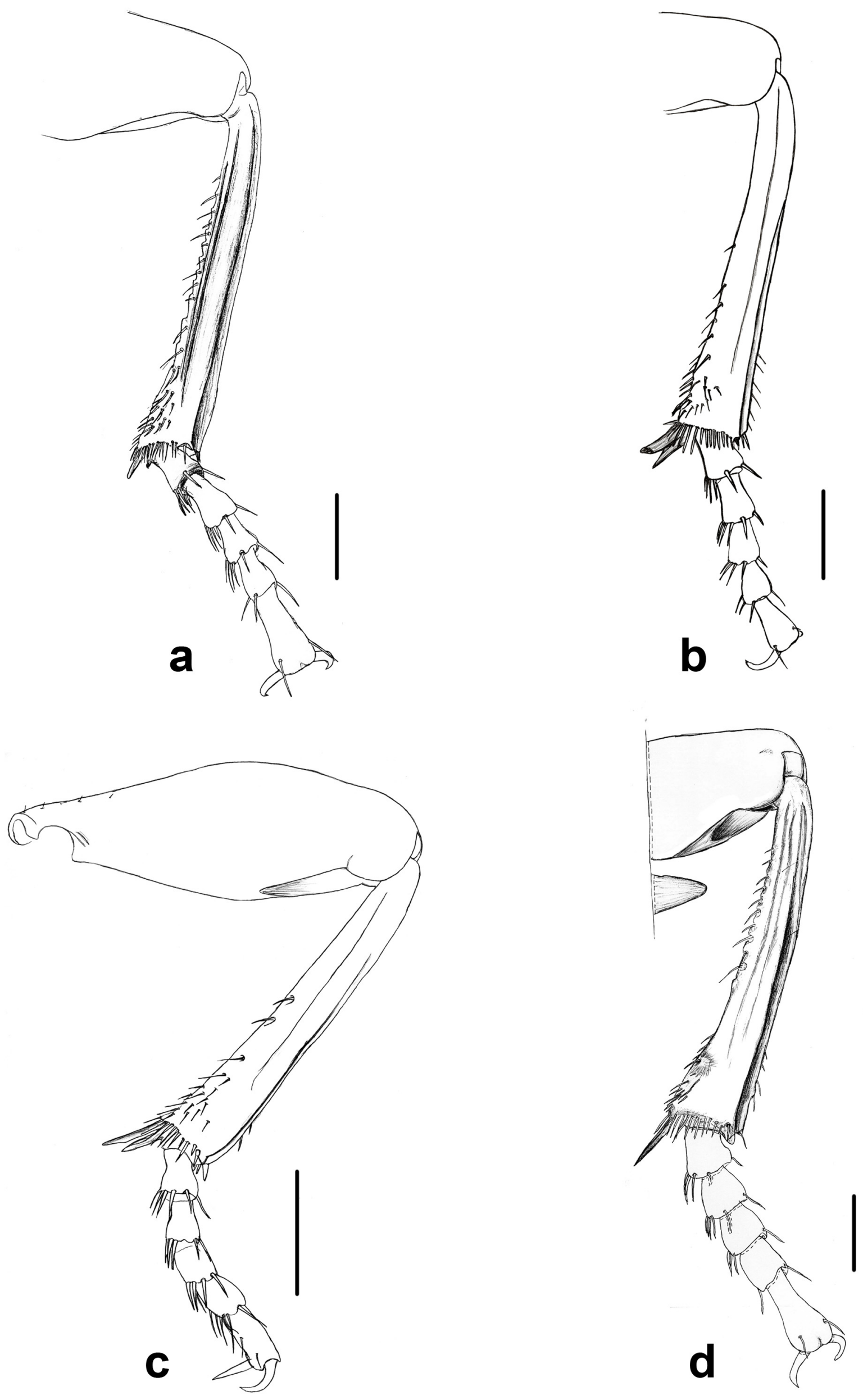

Prancha 34: Perna posterior (dorsal). (Apenas o tarso, tíbia e parte posterior do fêmur estão representados, exceto em c, onde o fêmur está completo e em d, onde o ápice do trocanter está representado). a. Morion cycloma; b. M. lafertii; c. M. monilicornis; d. M. simplex. Barras = $1 \mathrm{~mm}$. 

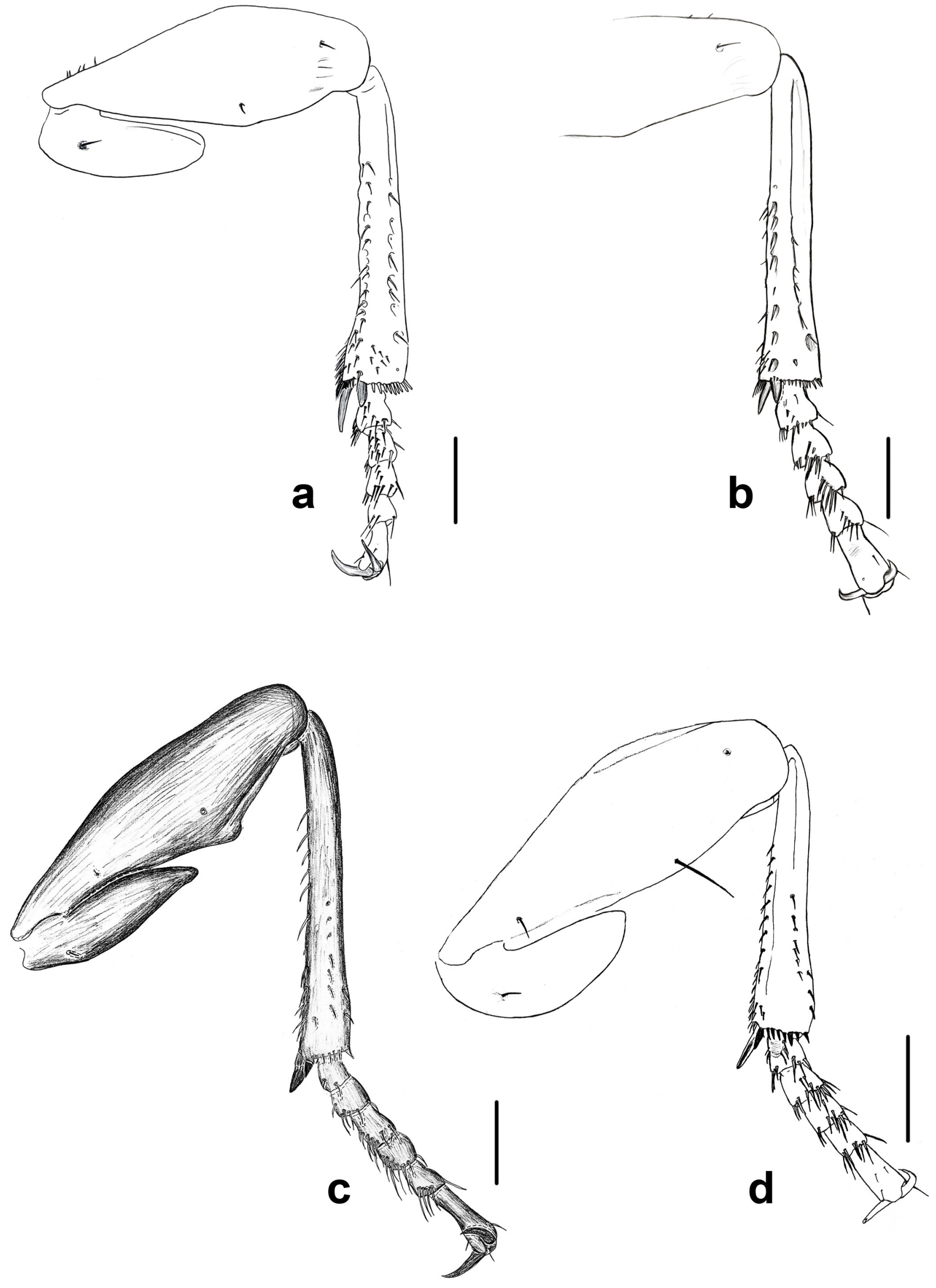

Prancha 35: Perna posterior (ventral). (Apenas o tarso, tíbia, fêmur e trocânter estão representado, exceto em $\mathbf{b}$, onde o fêmur está incompleto e o trocânter não está representado). $\mathbf{a}$. Morion arida; $\mathbf{b}$. M. boliviensis; c. M. brasiliensis; d. M. cordata. Barras $=1 \mathrm{~mm}$. 

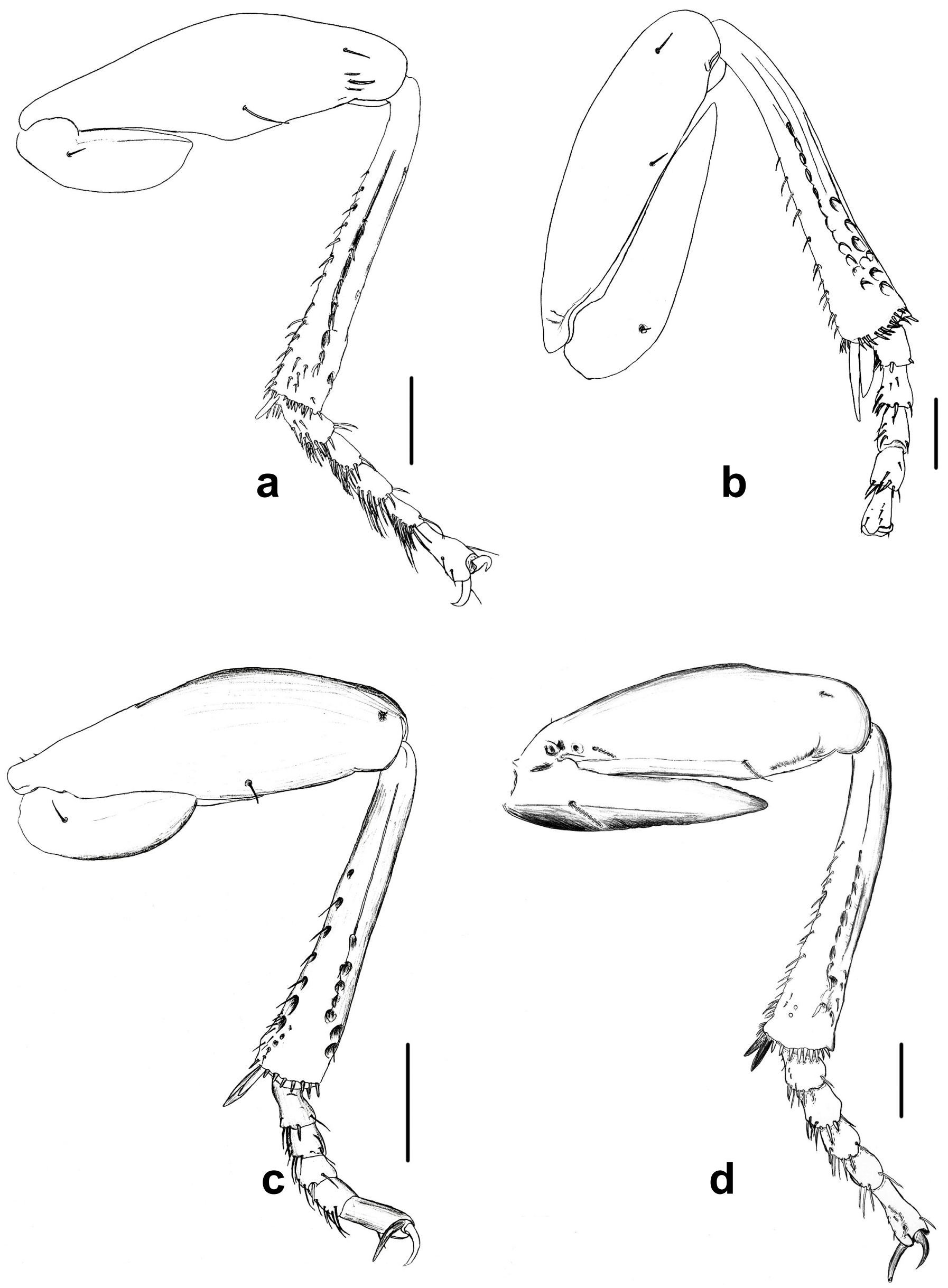

Prancha 36: Perna posterior (ventral). Apenas o tarso, tíbia e fêmur estão representados. a. Morion cycloma; b. M. lafertii; c. M. monilicornis; d. M. simplex. . Barras $=1 \mathrm{~mm}$. 


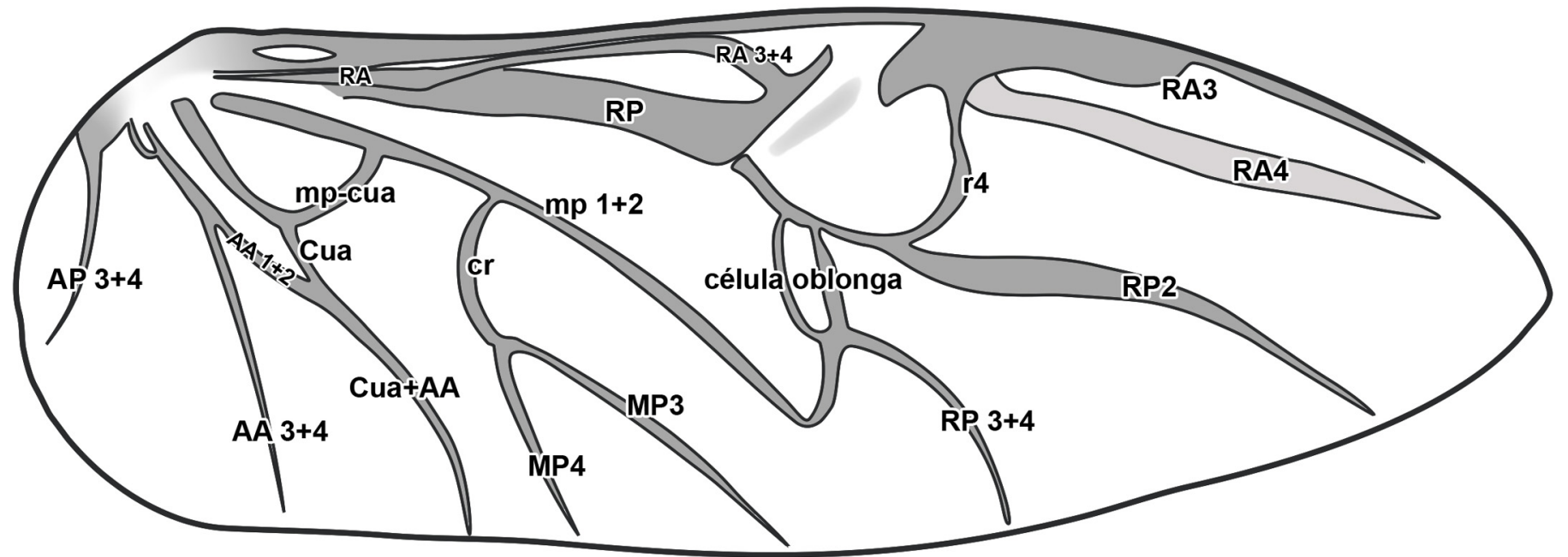

AP - Anal Posterior

AA - Anal Anterior

RA - Radial Anterior

mp-cua - Mediano-cubital transversal ou Arculus

MP - Mediana Posterior

RP - Radial Posterior

r4 e r4 - Radial Transversas

CuA - Cúbito Anterior

Prancha 37: Desenho esquemático da asa membranosa de Morion. 

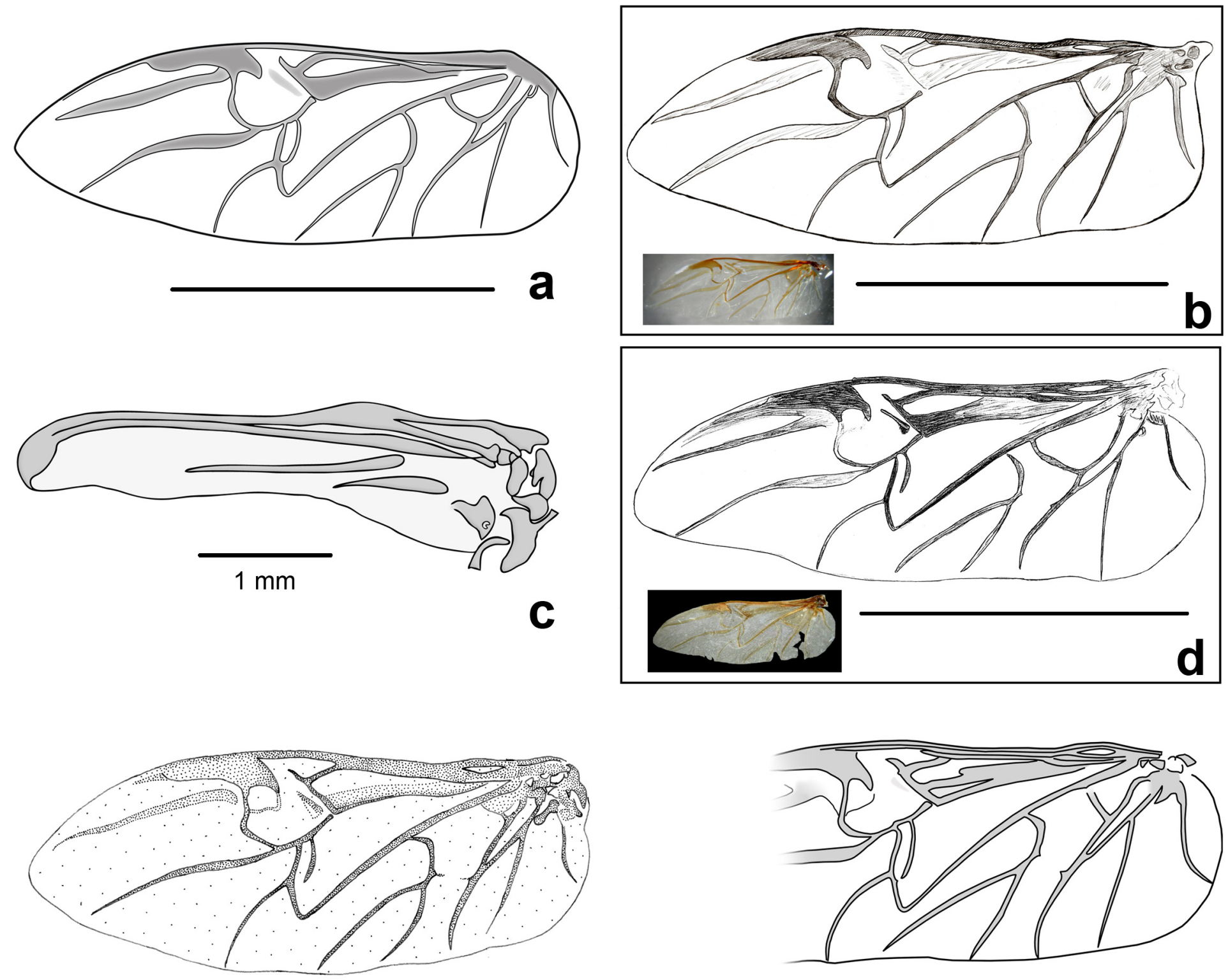

e
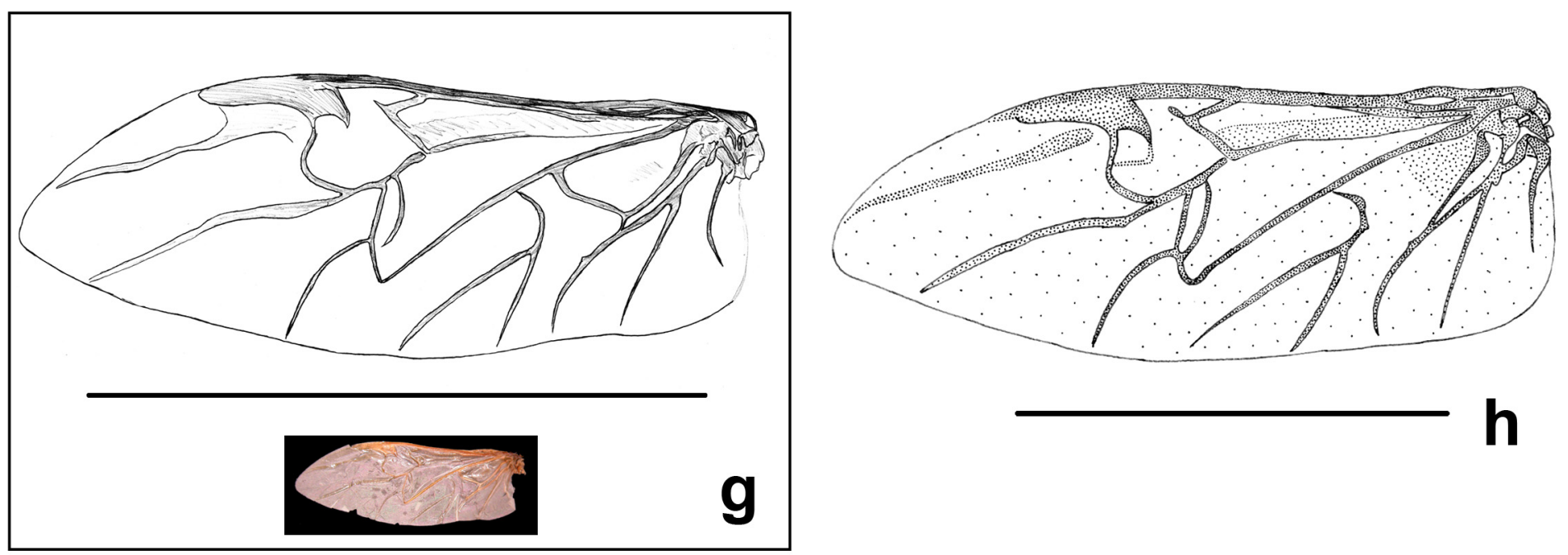

Prancha 38: Asa membranosa. a. Morion arida; b. boliviensis (desenho e foto); c. M. brasiliensis; d. $M$. cordata (desenho e foto); e. M. cycloma; f. M. lafertii (ilustração da parte médio-anterior); g. M. monilicornis (desenho e foto); h. M. simplex. Barras $=10 \mathrm{~mm}$, exceto fig. $\mathbf{c}=1 \mathrm{~mm}$ (exceto fotos). 

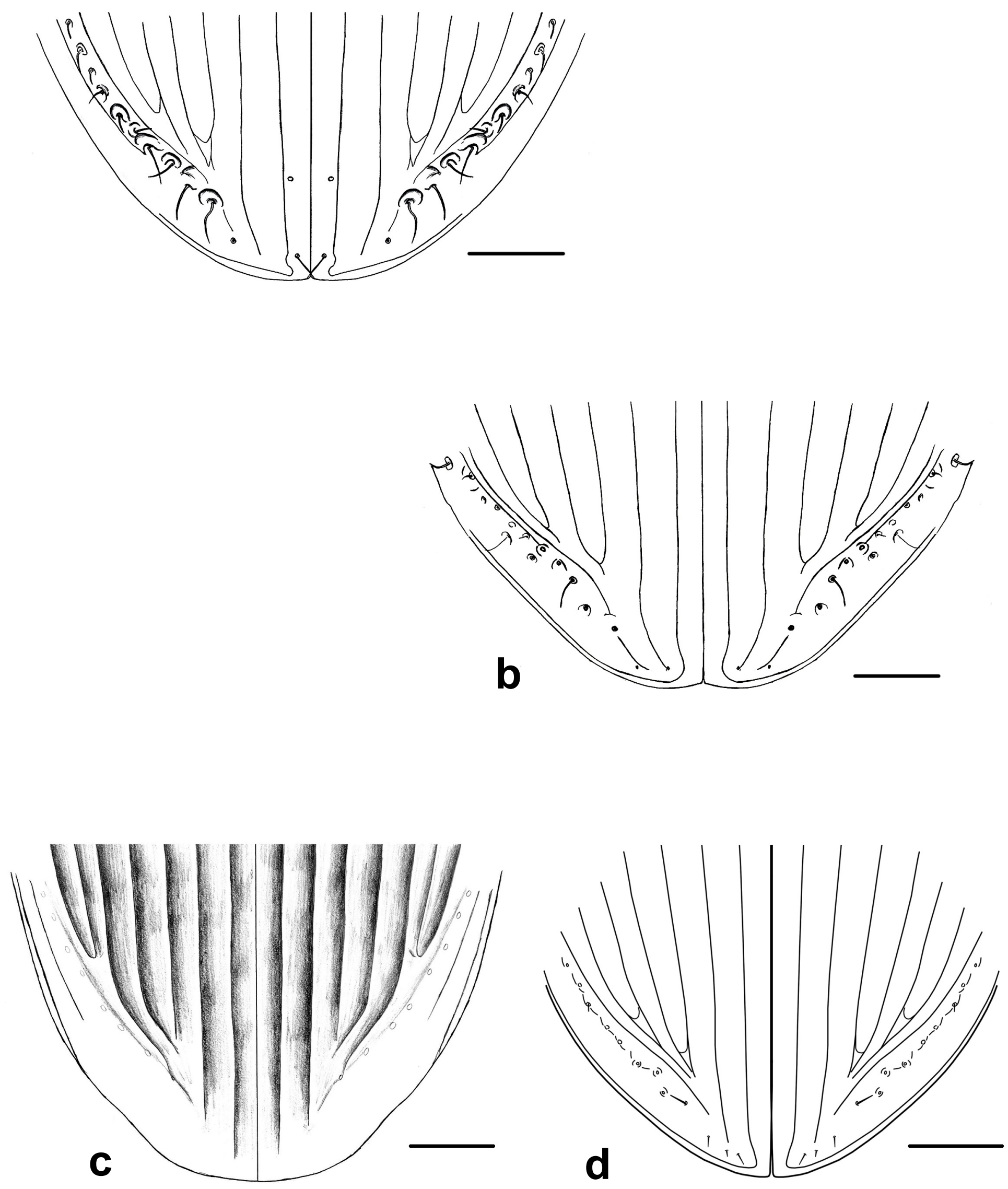

Prancha 39: Ápice dos élitros. a. Morion aridus; b. M. boliviensis; c. M. brasiliensis; d. M. cordata. Barras $=1 \mathrm{~mm}$. 

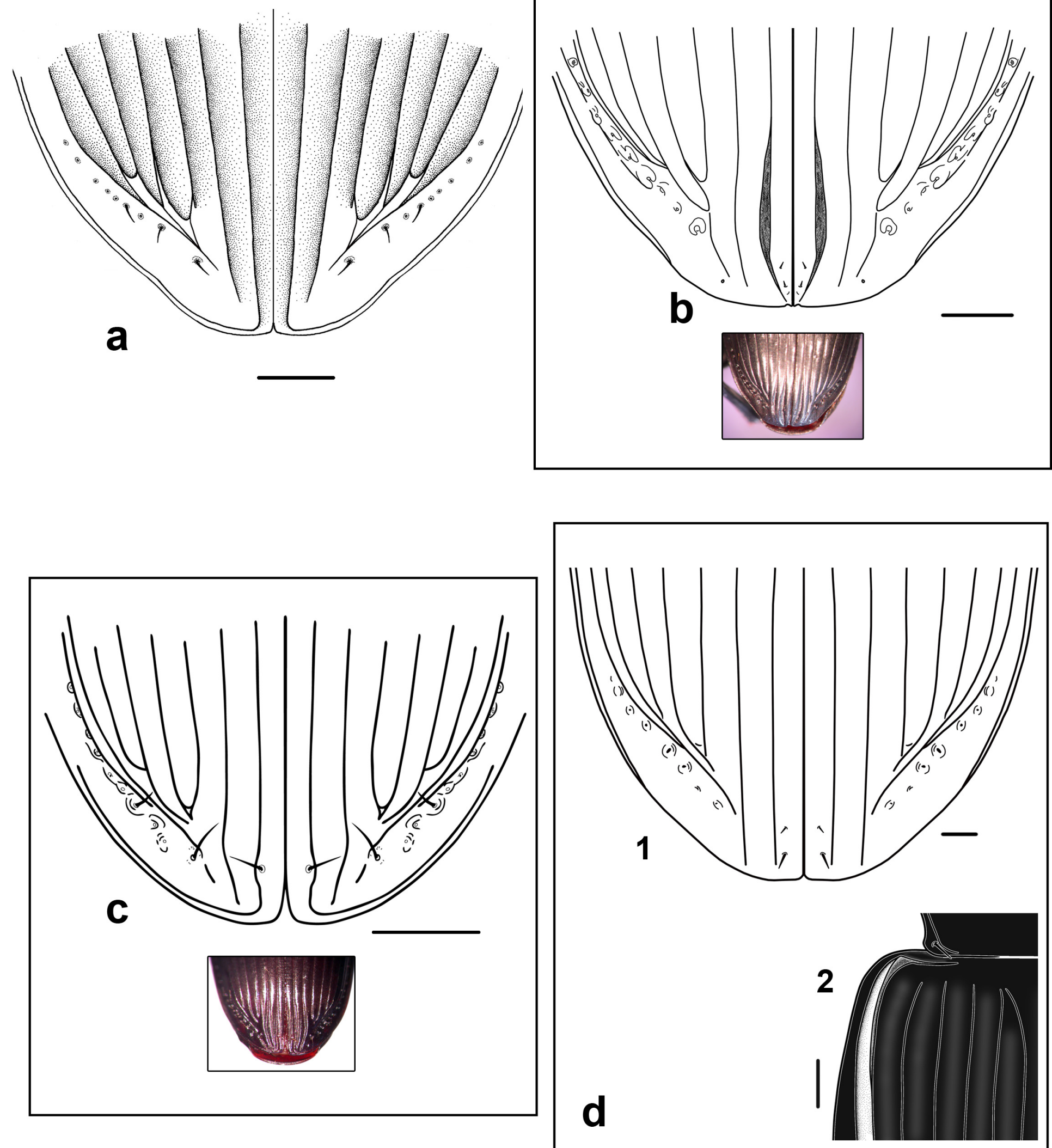

Prancha 40: Ápice dos élitros. a. Morion cycloma; b. M. lafertii (desenho e foto); c. M. monilicornis (desenho e foto); d. M. simplex (1. ápice do élitro; 2 . detalhe da sexta interestria costiforme no terço anterior). Barras $=1 \mathrm{~mm}$ (exceto fotos). 

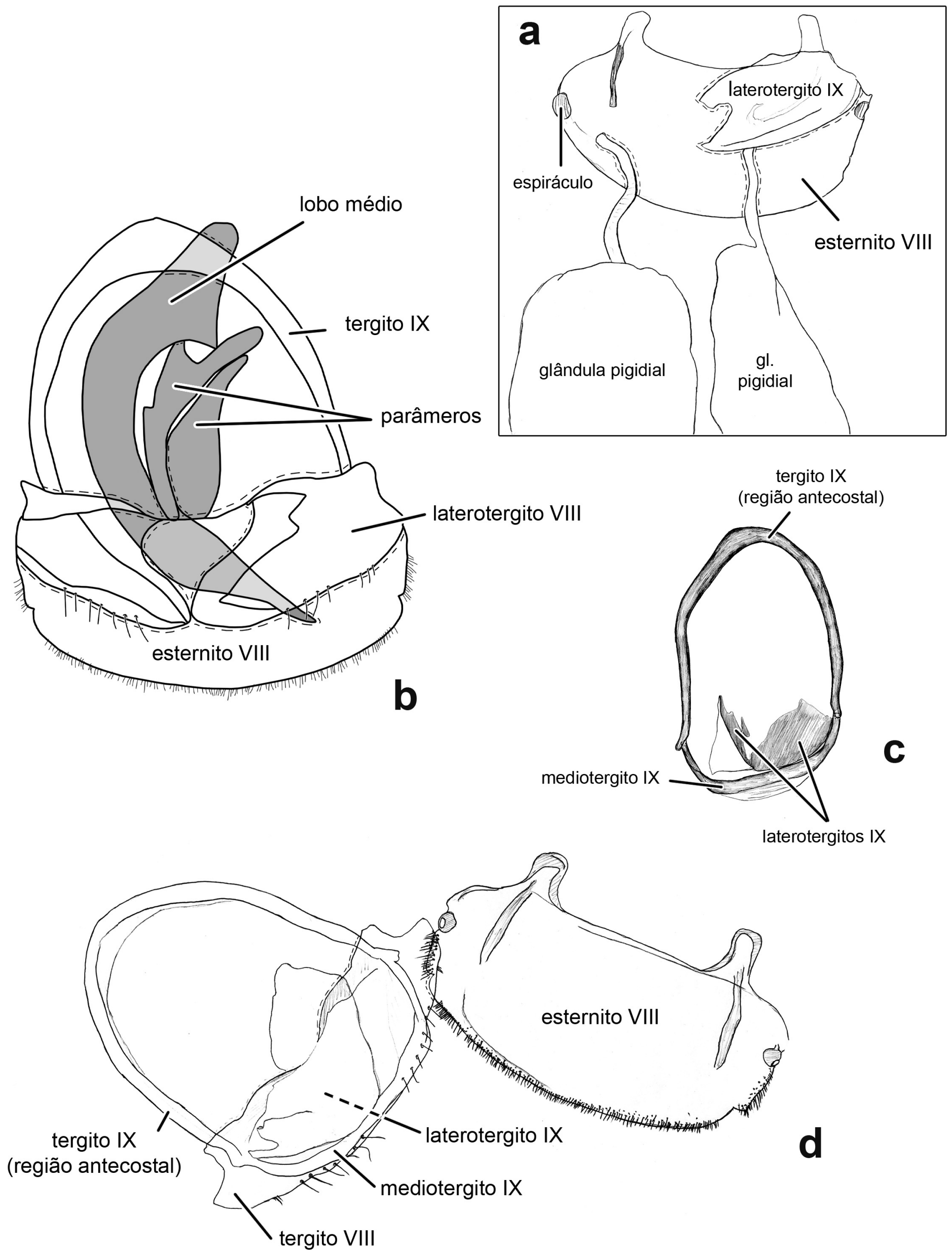

Prancha 41: Desenhos esquemáticos dos segmentos genitais masculinos e edeago de Morion. a. segmentos genitais (dorsal); b. segmentos genitais e edeago (dorsal); c. tergito IX e d. segmentos genitais (ventral). 

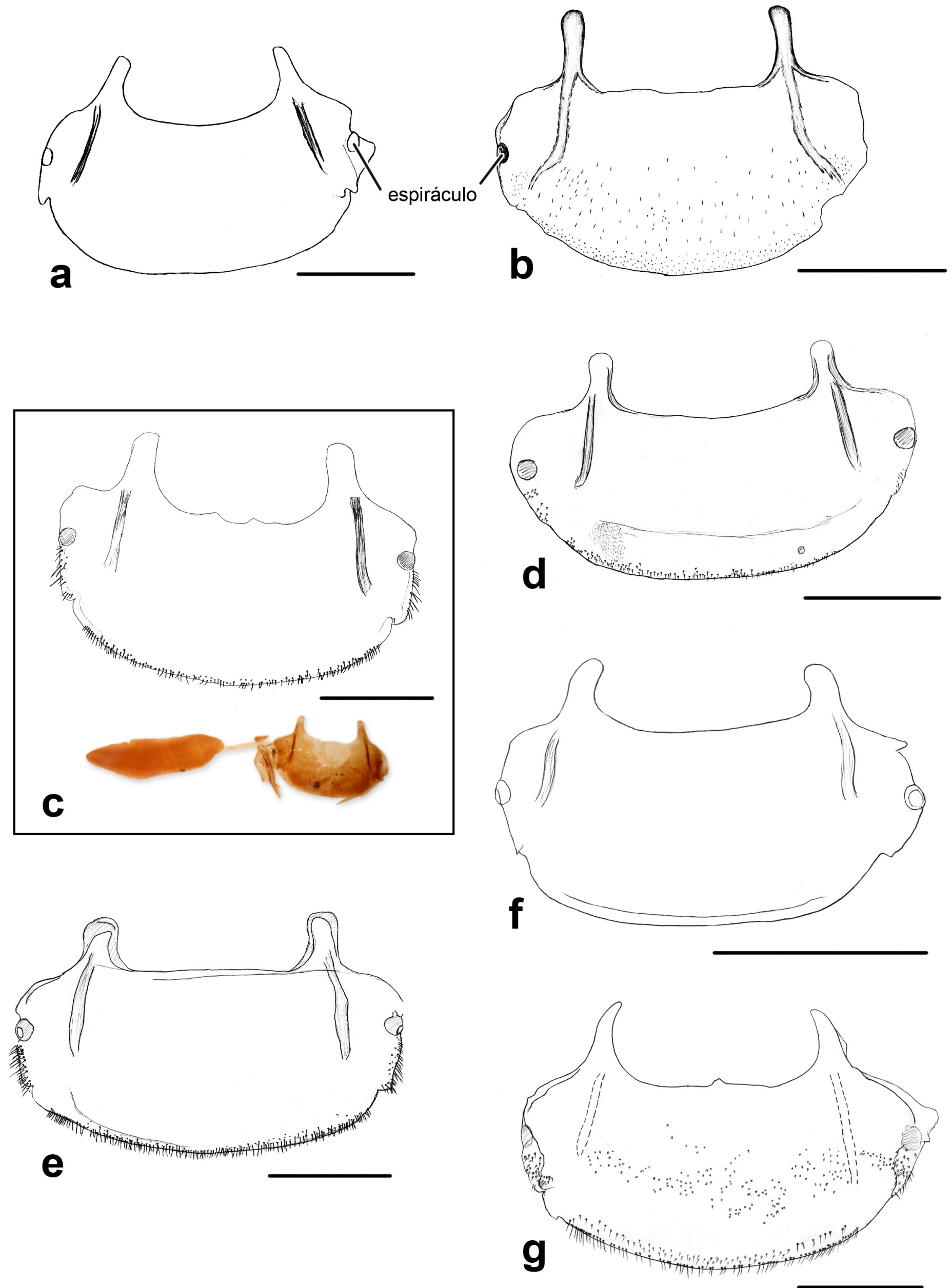

Prancha 42: Esternito VIII (machos). a. Morion boliviensis (cerdas não representadas); b. M. brasiliensis; c. M. cordata (desenho e foto do segmento com uma das duas glândulas pigidiais); d. M. cycloma; e. M. lafertii; f. M. monilicornis (cerdas não representadas); g. $M$. simplex. Barras $=1 \mathrm{~mm}$. 

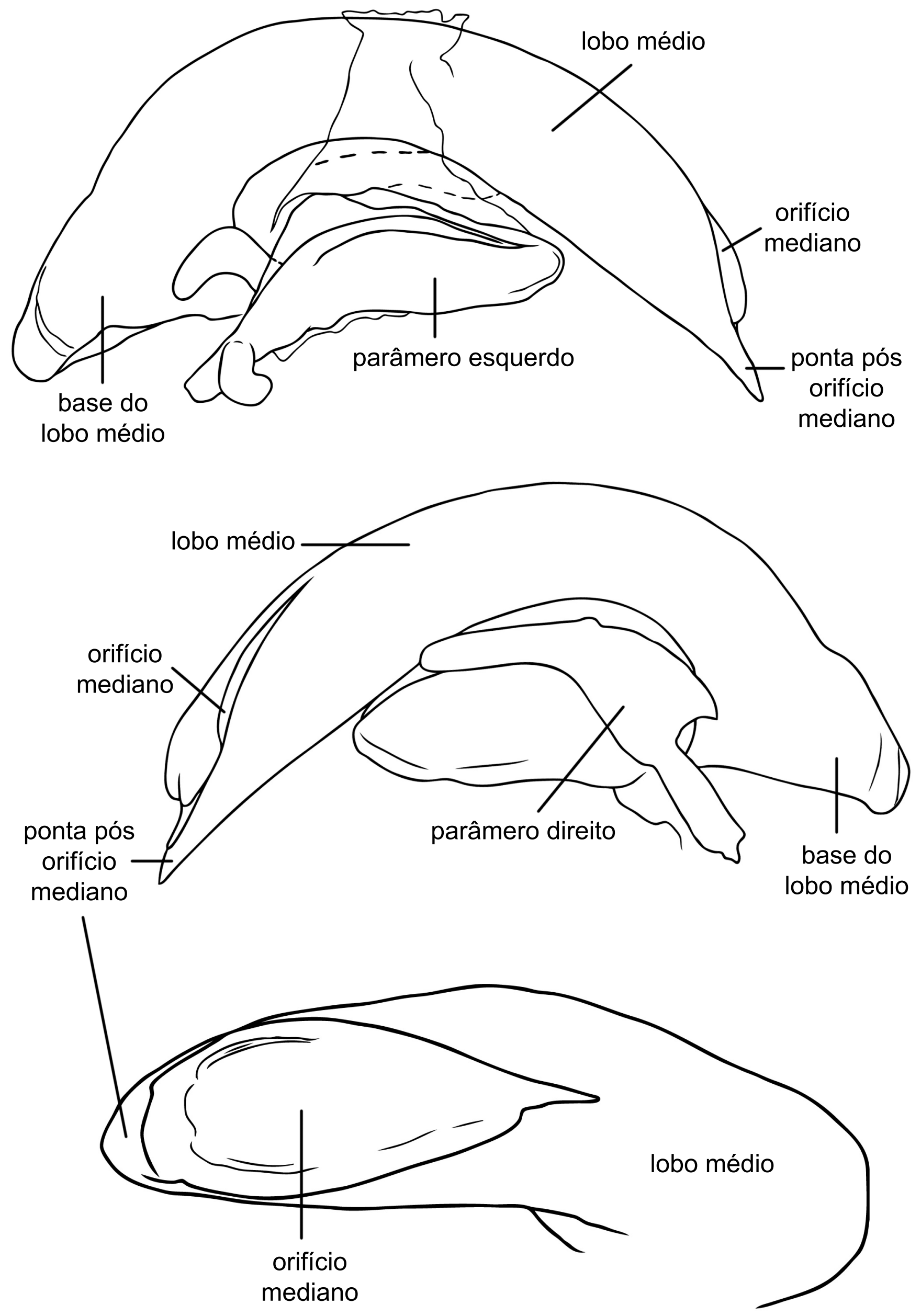

Prancha 43: Desenho esquemático do edeago de Morion. a. vista lateral esquerda; b. vista lateral direita; c. vista frontal ao orifício mediano. 

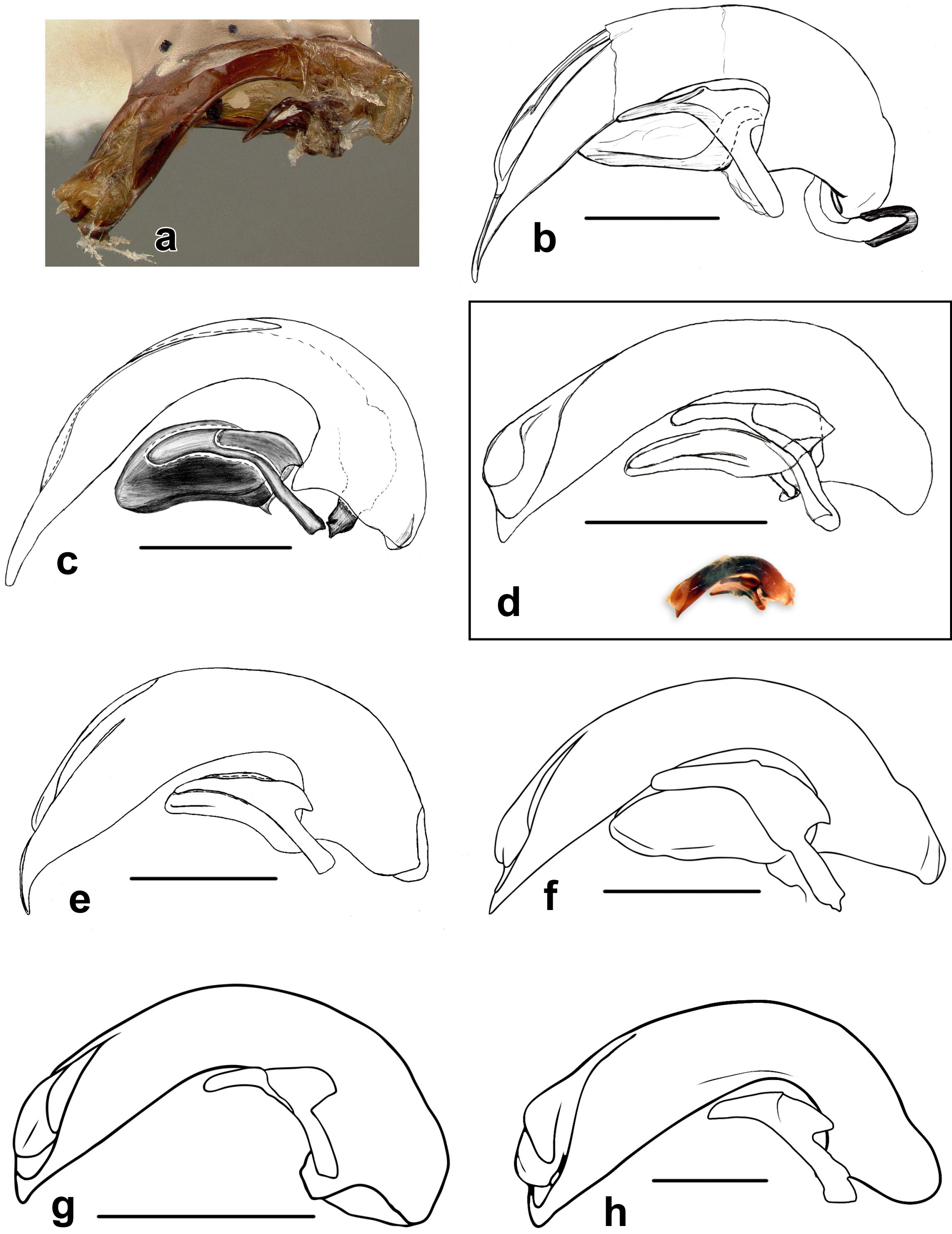

Prancha 44: Edeago - vista lateral direita. a. Morion arida (fotografia do holótipo); b. M. boliviensis; c. M. brasiliensis; d. M. cordata (desenho e foto); e. M. cycloma; f. M. lafertii; g. M. monilicornis; h. M. simplex. Barras $=1 \mathrm{~mm}$ (exceto fotos). 

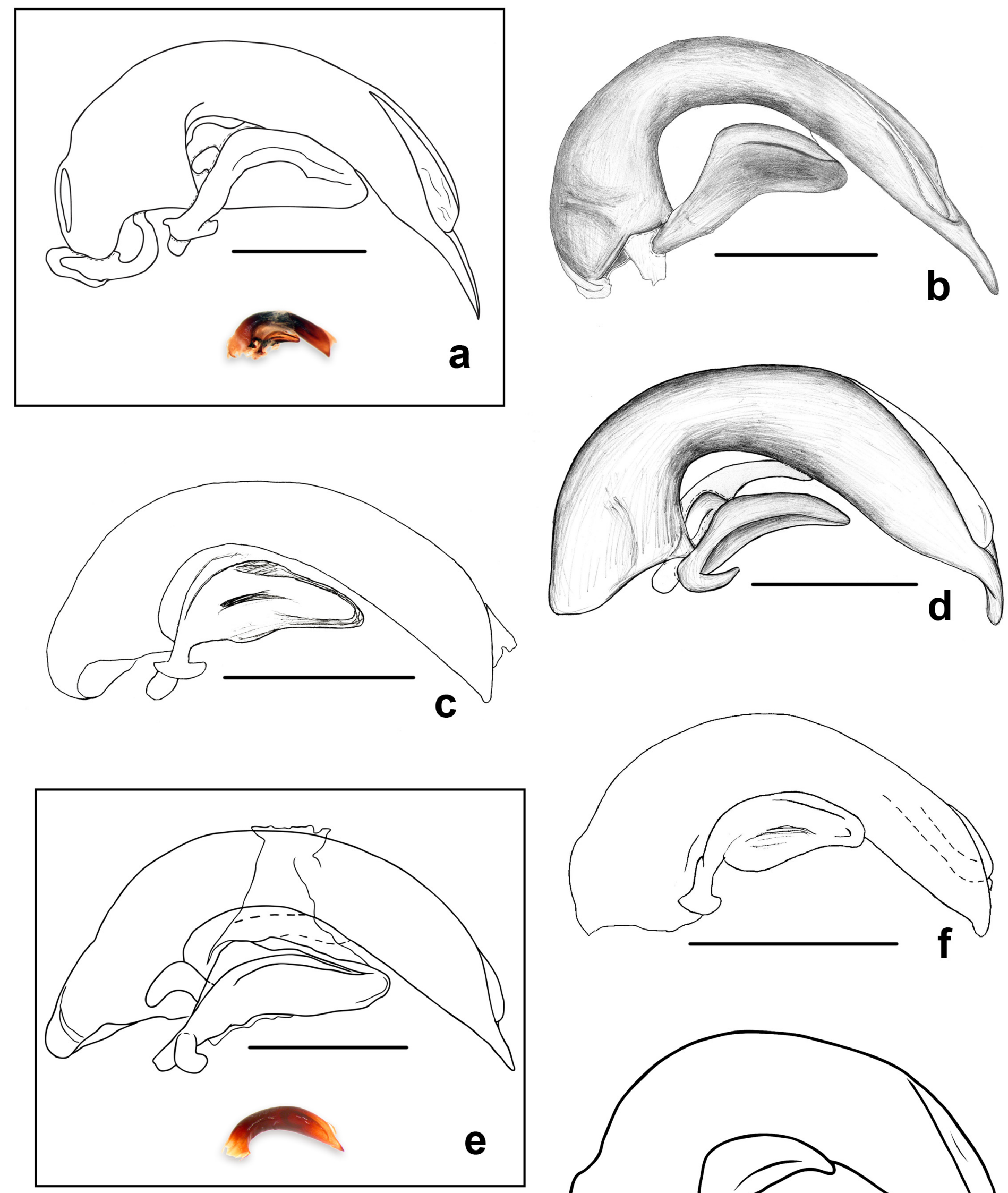

Prancha 45: Edeago - vista lateral esquerda. a. Morion boliviensis (desenho e foto); b. M. brasiliensis; c. M. cordata; d. M. cycloma; e. M. lafertii (desenho e foto do lobo médio); f. M. monilicornis; g. M. simplex. Barras $=1 \mathrm{~mm}$. 

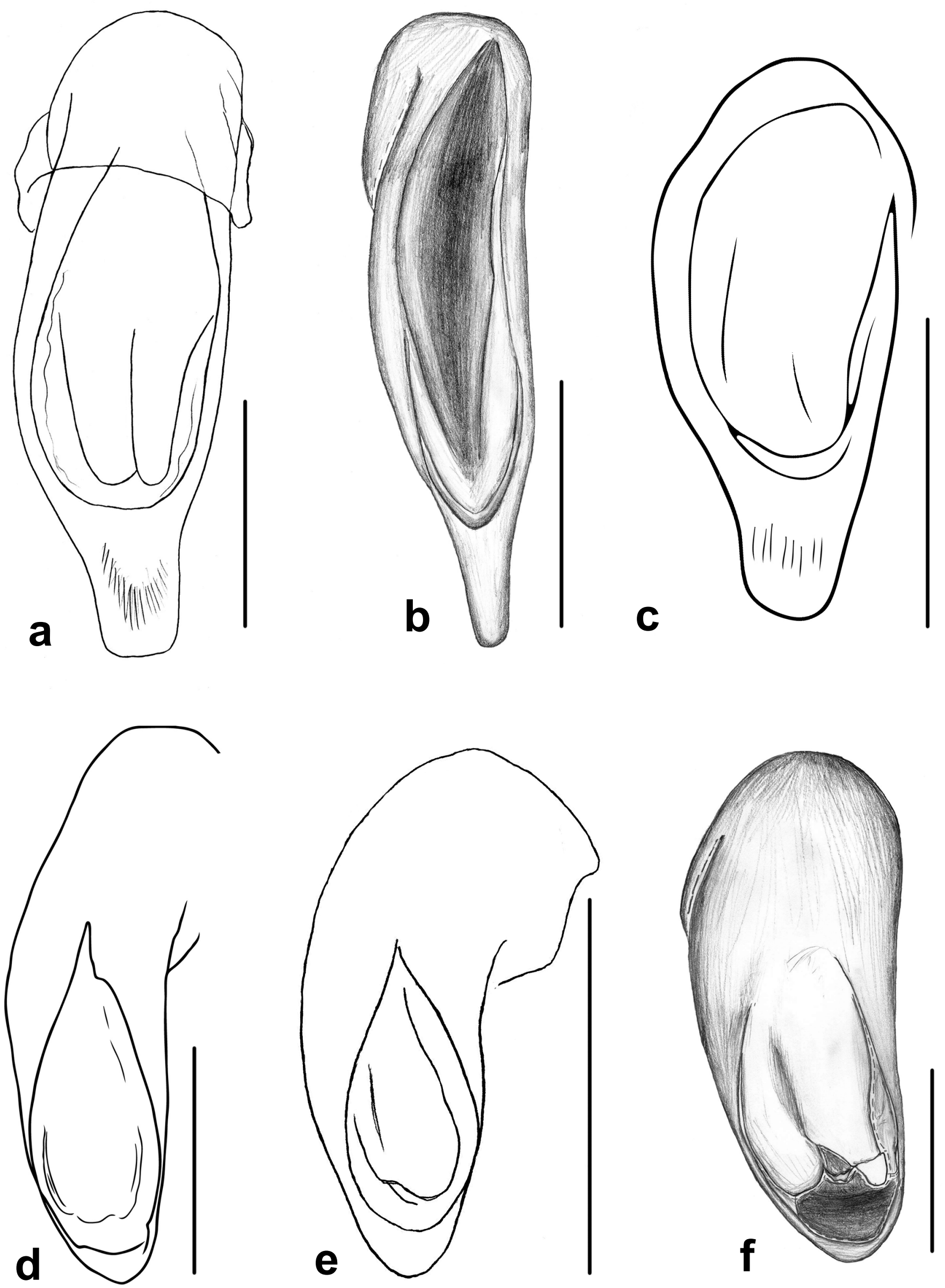

Prancha 46: Edeago - vista frontal. a. M. boliviensis; b. M. brasiliensis; c. M. cycloma; d. M. lafertii; e. M. monilicornis; f. M. simplex. Barras $=1 \mathrm{~mm}$. 

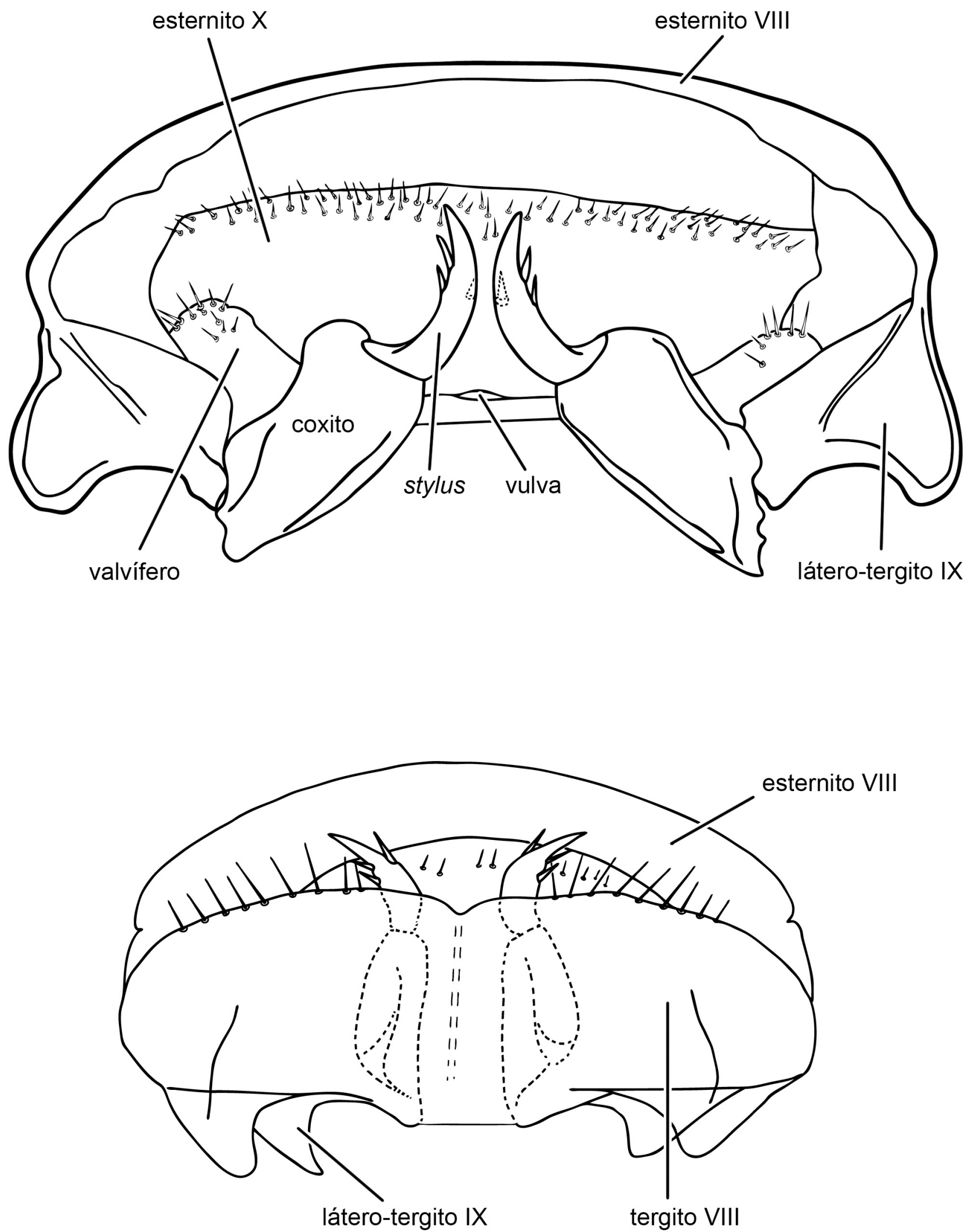

Prancha 47: Desenhos esquemáticos da genitália feminina de Morion. a. vista dorsal com esternito VIII ausente); b. vista dorsal com esternito VIII cobrindo algumas partes. 


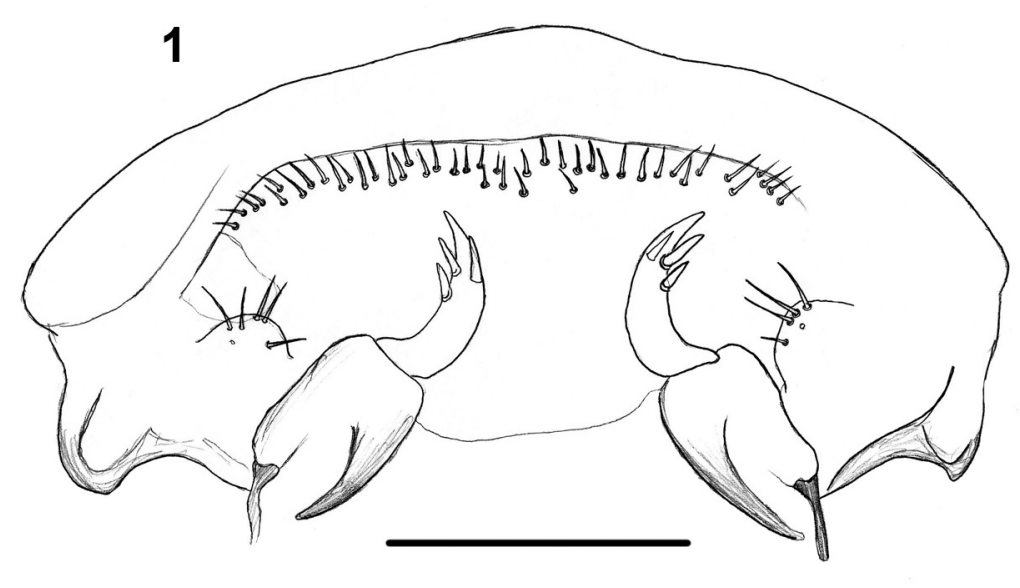

2

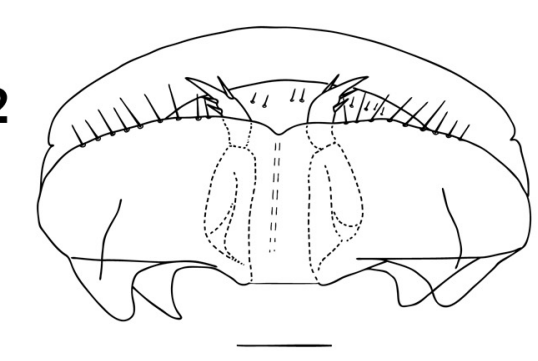

3

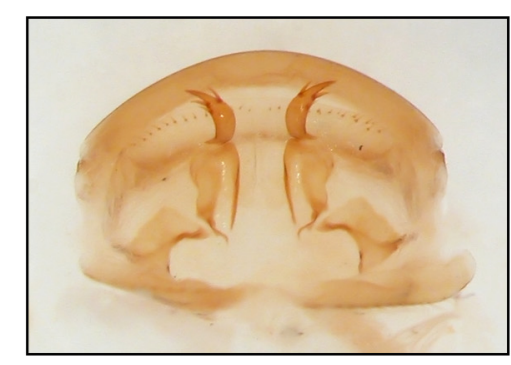

b
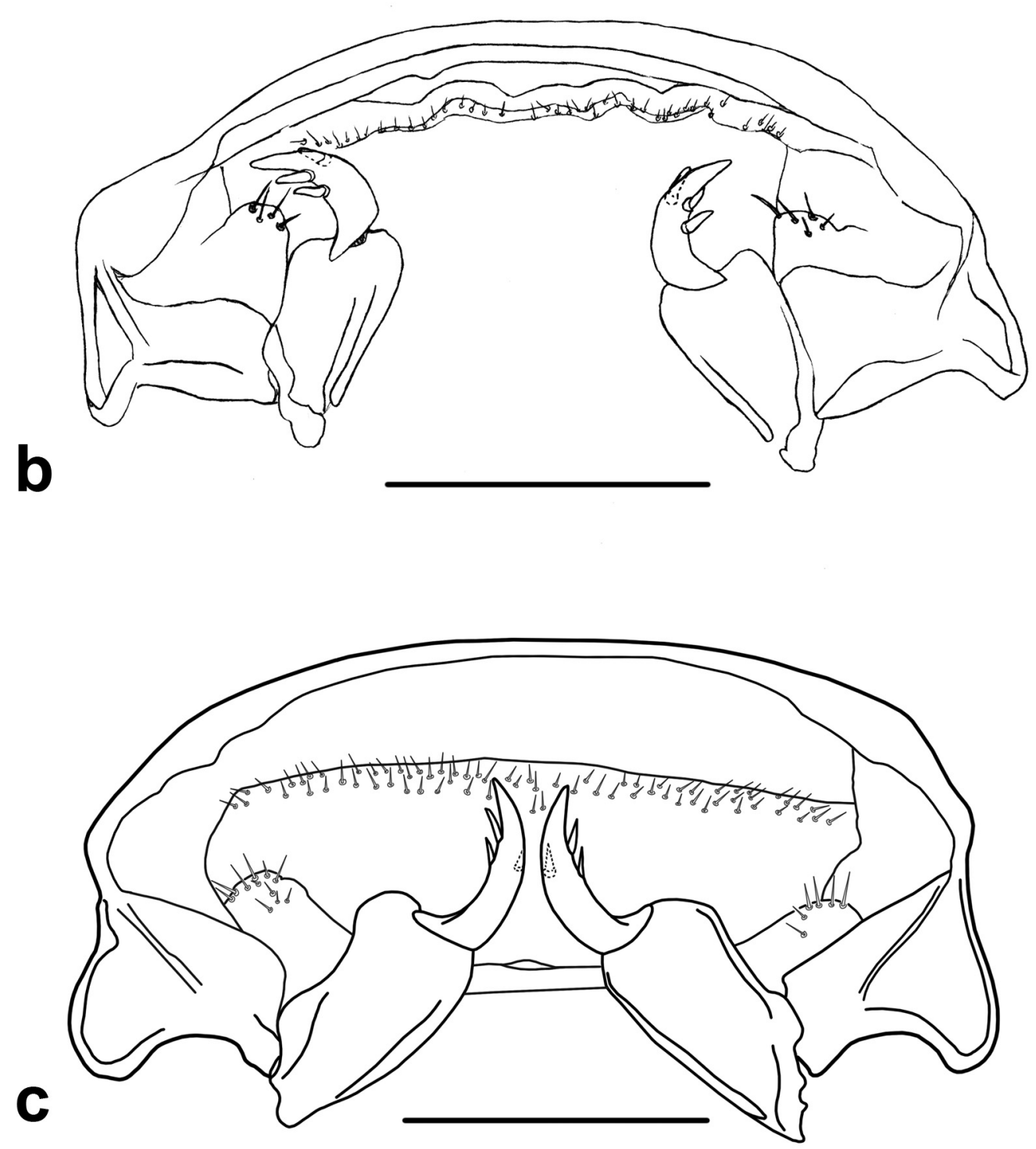

Prancha 48: Genitália feminina de Morion (estão representados também os esternitos VIII, IX e X). a. M. brasiliensis (1. tergito VIII foi removido; 2. com o tergito VIII; 3. foto da genitália com o valvífero glabro); b. M. cyclomus; c. M. simplex. Barra $=1 \mathrm{~mm}$ (exceto fotos). 

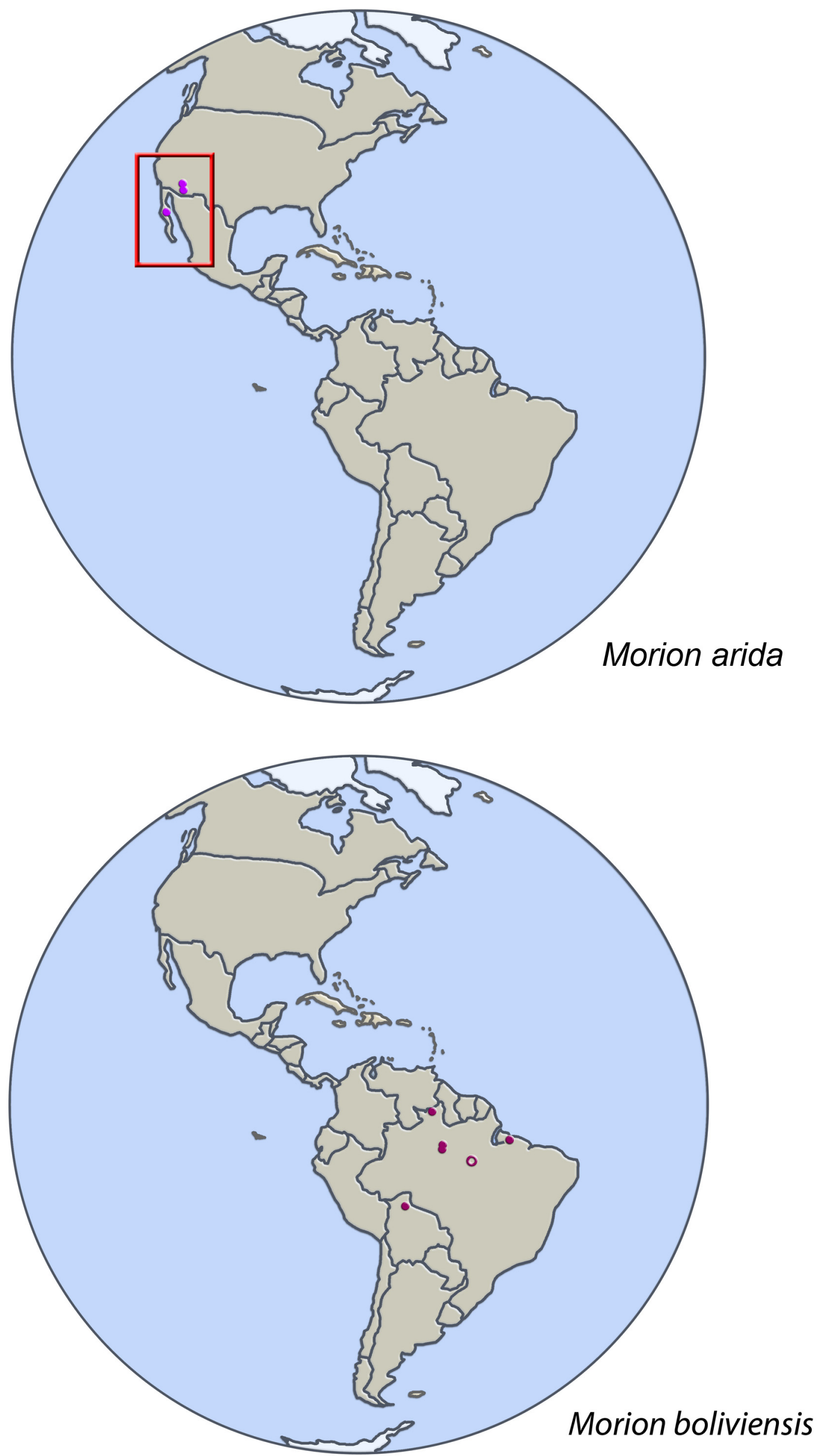

Prancha 49: Mapas com a distribuição geográfica das espécies Morion arida e Morion boliviensis baseada no material examinado. Os pontos abertos representam localidades não exatas. A moldura vermelha é apenas para facilitar a localização dos pontos. 

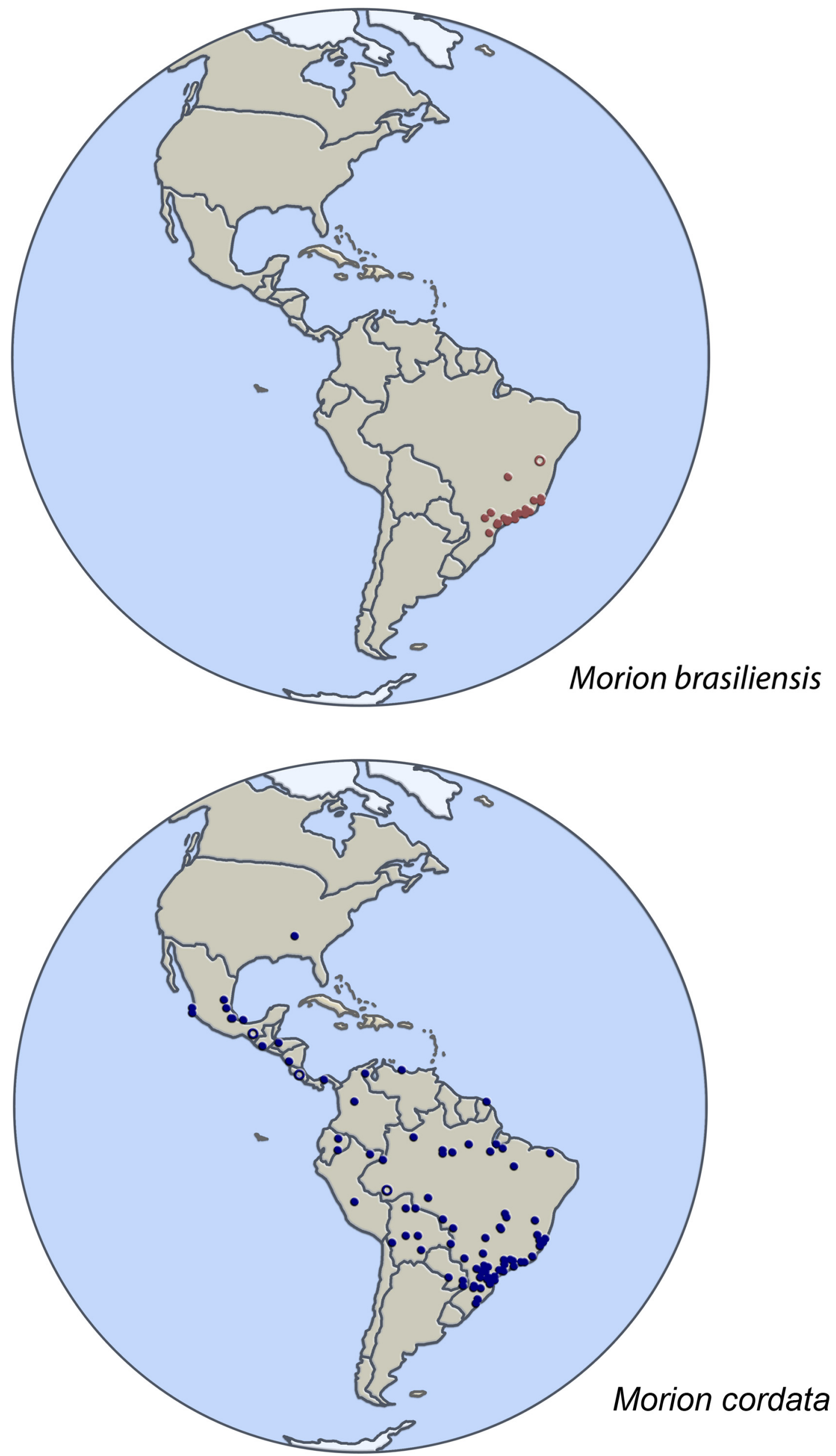

Prancha 50: Mapas com a distribuição geográfica das espécies Morion brasiliensis e Morion cordata baseada no material examinado. Os pontos abertos representam localidades não exatas. 

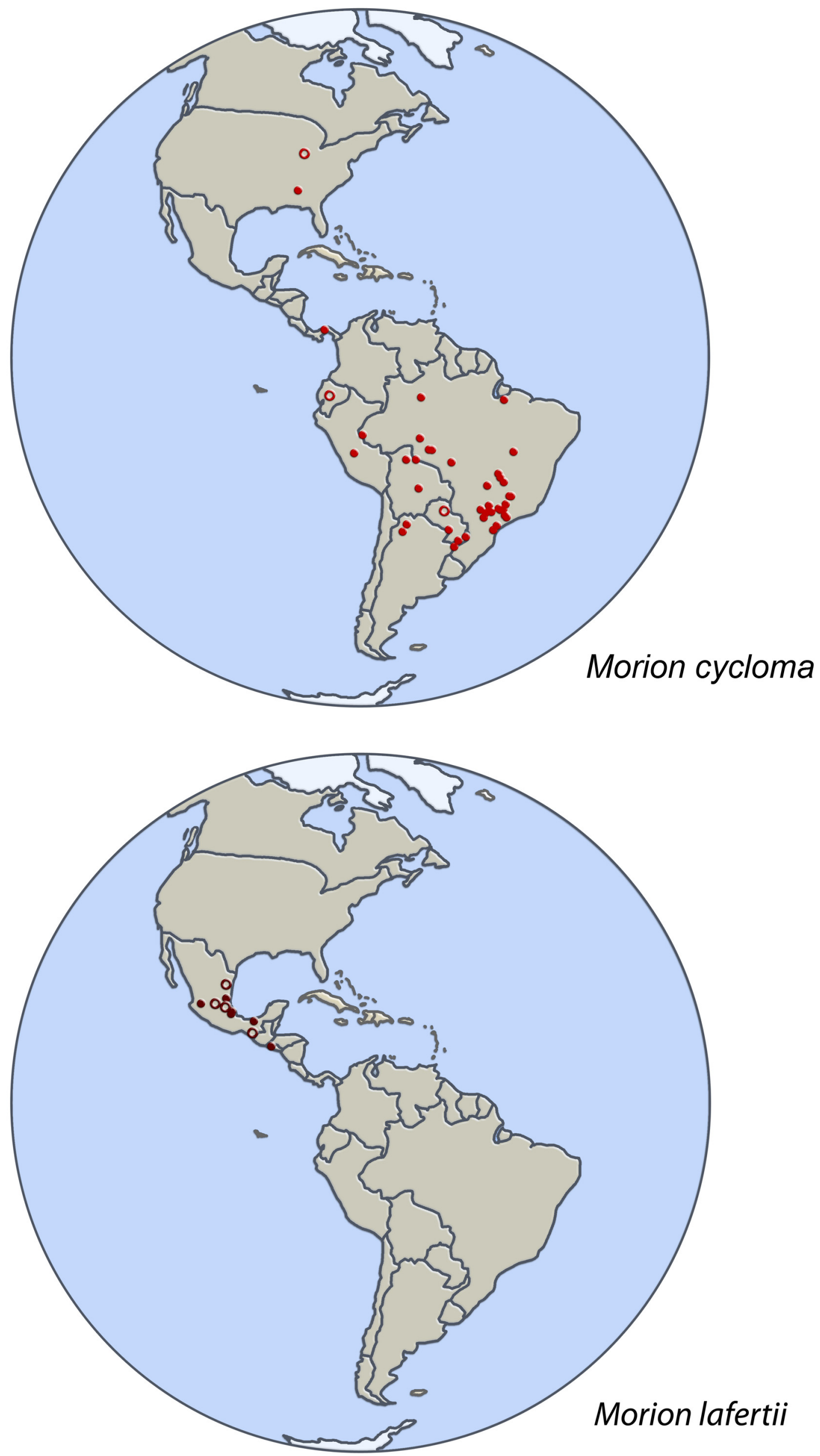

Prancha 51: Mapas com a distribuição geográfica das espécies Morion cycloma e Morion lafertii baseada no material examinado. Os pontos abertos representam localidades não exatas. 

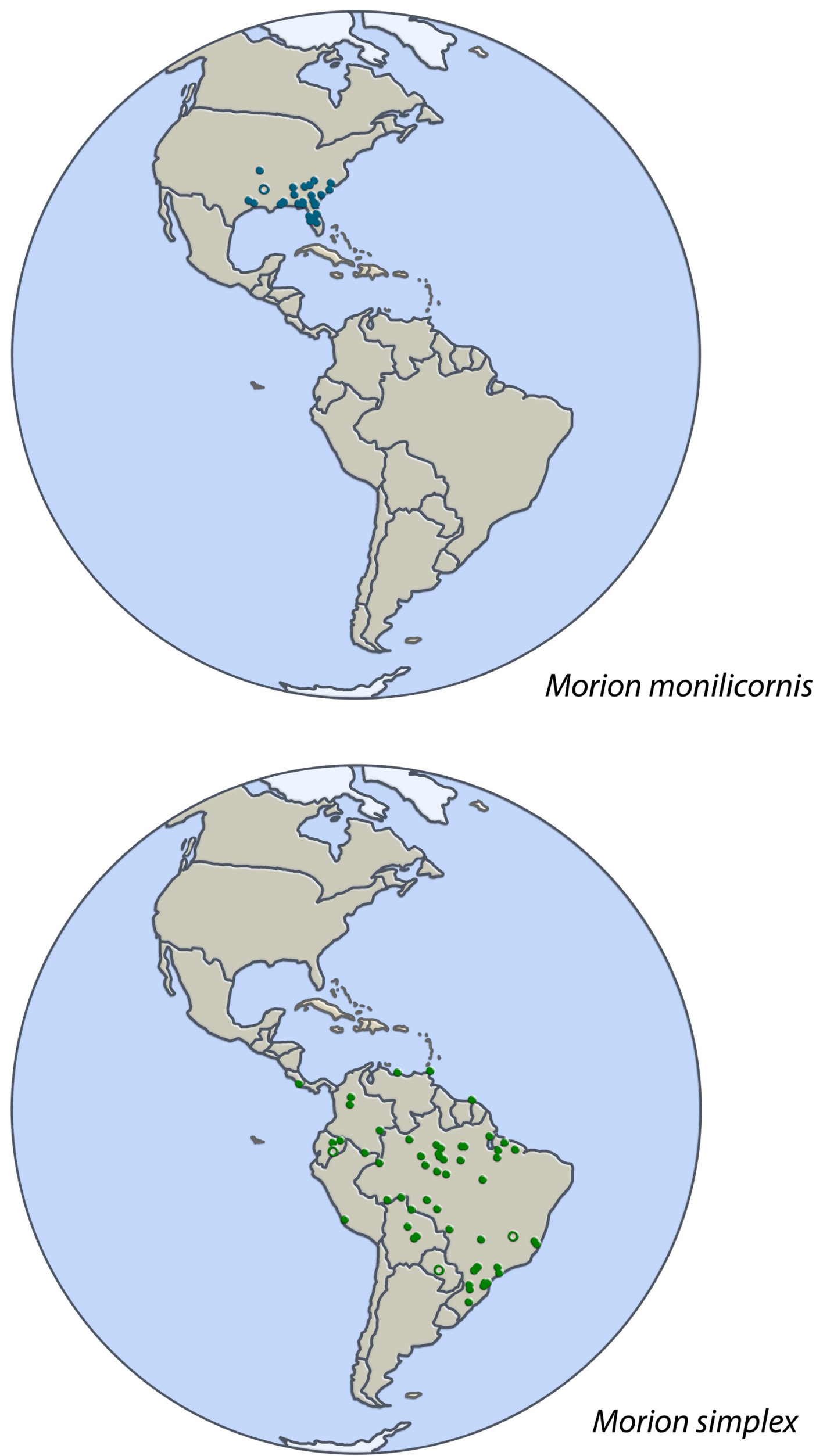

Prancha 52: Mapas com a distribuição geográfica das espécies Morion monilicornis e Morion simplex baseada no material examinado. Os pontos abertos representam localidades não exatas. 

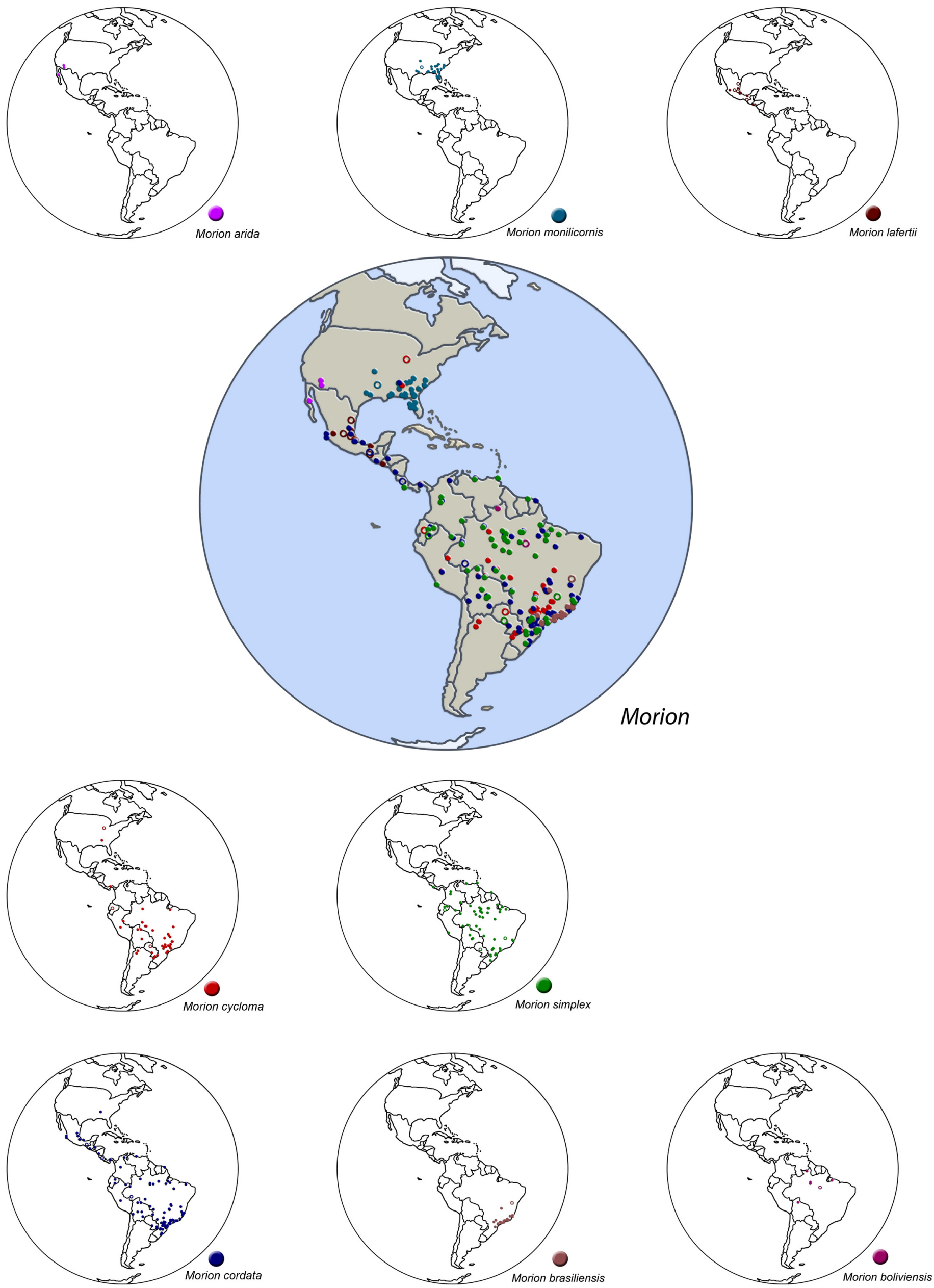

Prancha 53: Distribuição geográfica das espécies de Morion das Américas. Cada mapa pequeno representa a distribuição de uma espécie. Os pontos referem-se às localidades obtidas das etiquetas do material examinado; os pontos abertos às localidades não exatas. O mapa grande central une as informações dos mapas menores. 

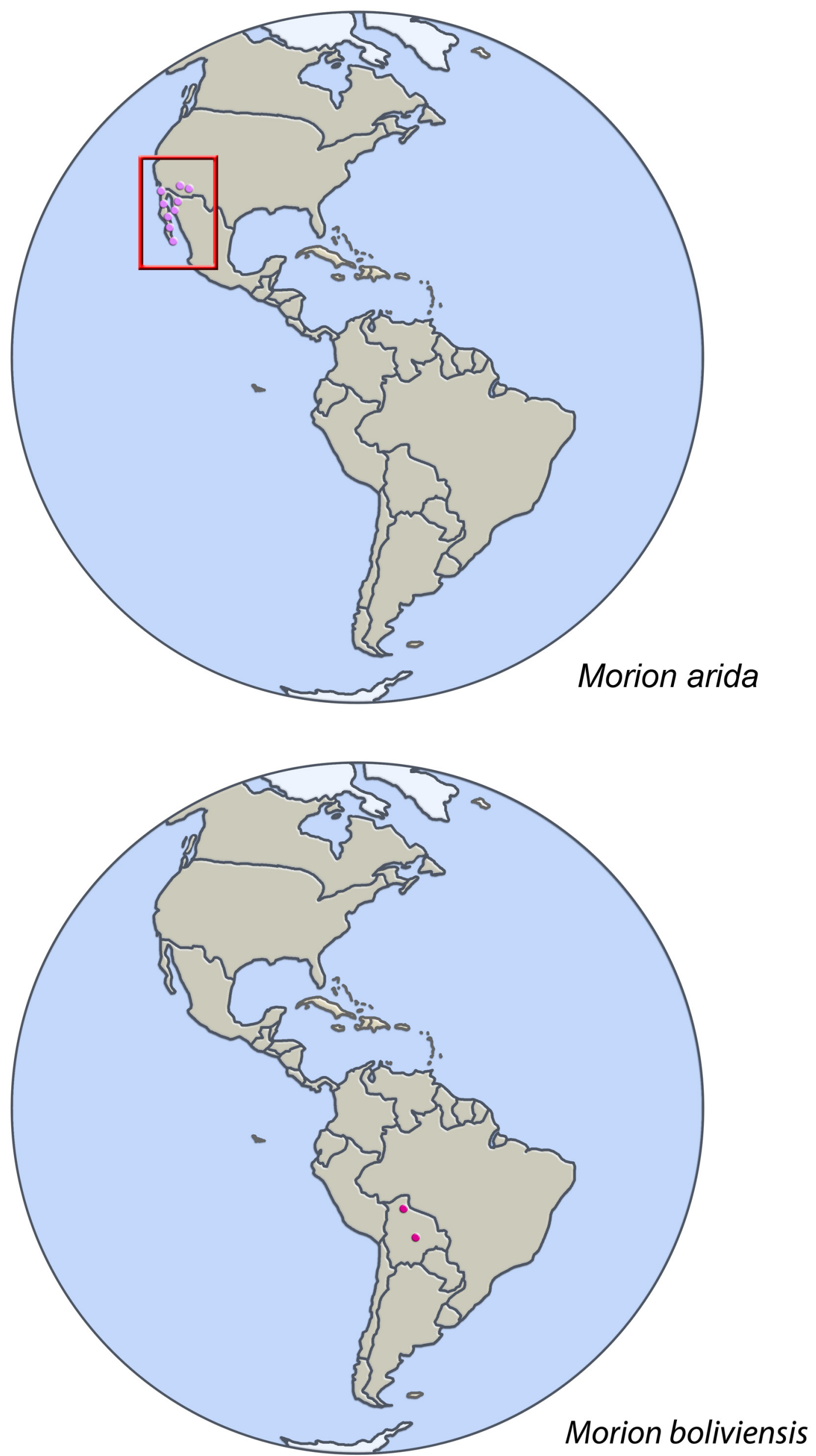

Prancha 54: Mapas com a distribuição geográfica das espécies Morion arida e Morion boliviensis, baseada em dados da literatura. Os pontos abertos representam localidades não exatas. A moldura vermelha é apenas para facilitar a localização dos pontos. 

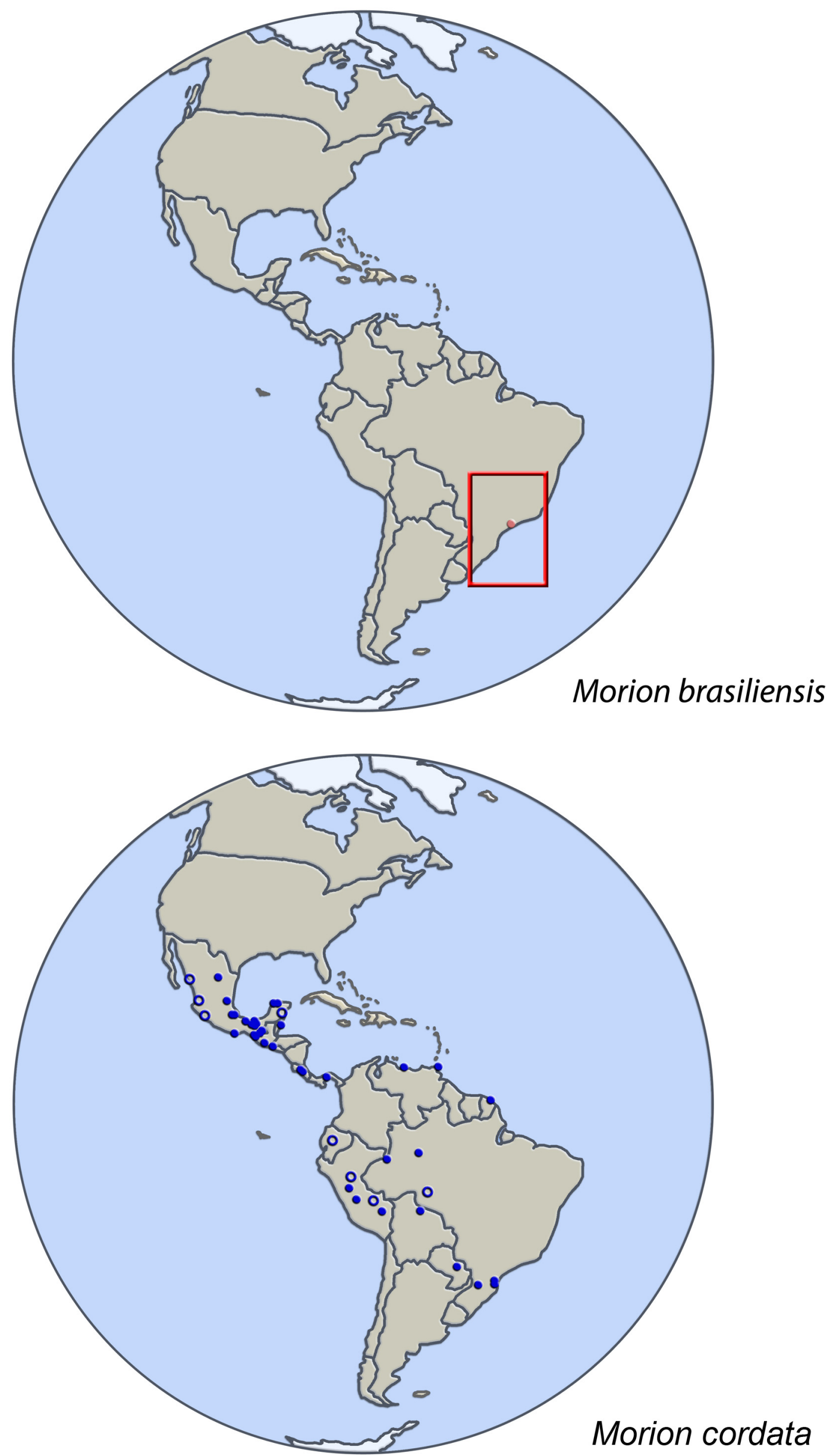

Prancha 55: Mapas com a distribuição geográfica das espécies Morion brasiliensis e Morion cordata, baseada em dados da literatura. Os pontos abertos representam localidades não exatas. A moldura vermelha é apenas para facilitar a localização dos pontos. 

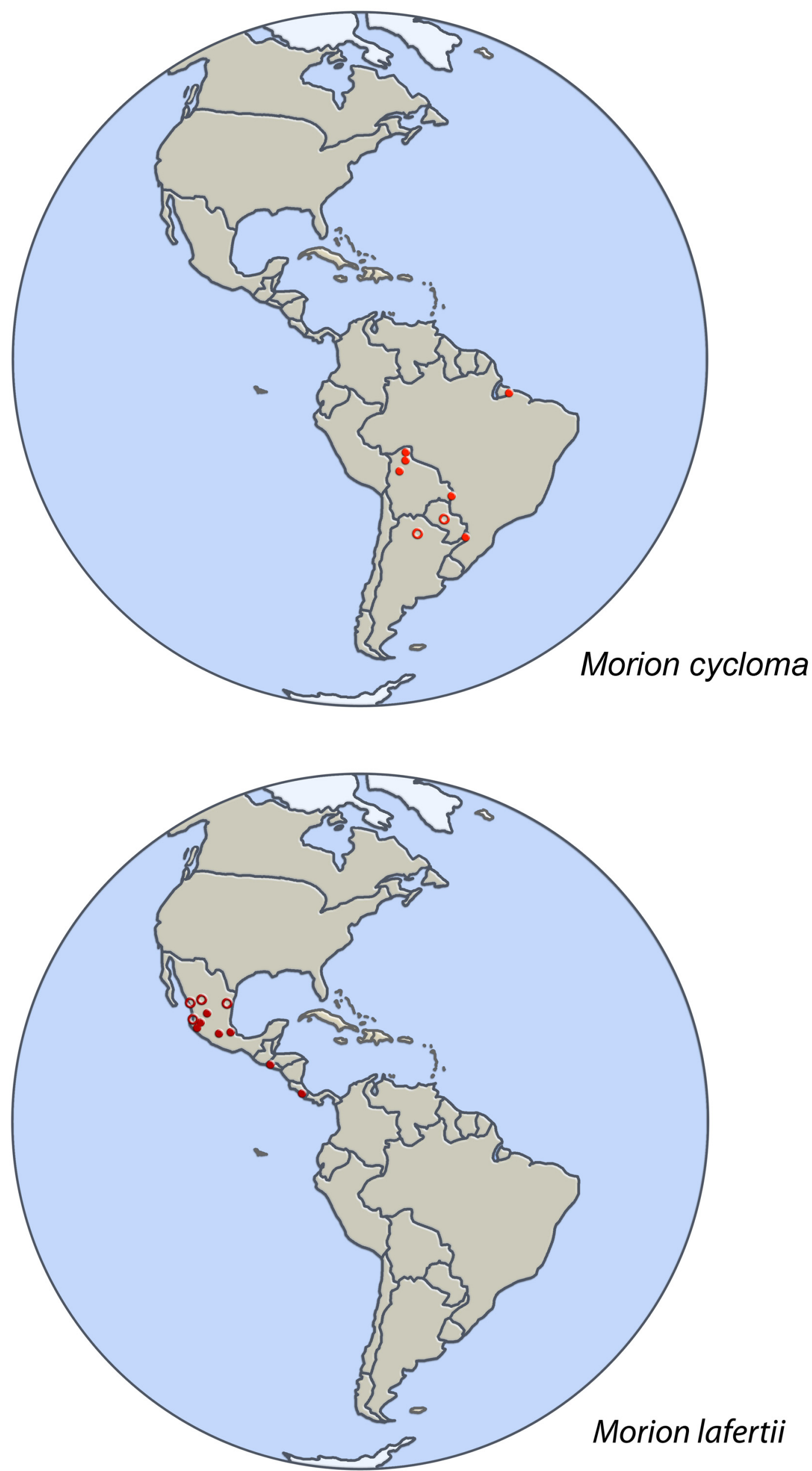

Prancha 56: Mapas com a distribuição geográfica das espécies Morion cycloma e Morion lafertii, baseada em dados da literatura. Os pontos abertos representam localidades não exatas. 

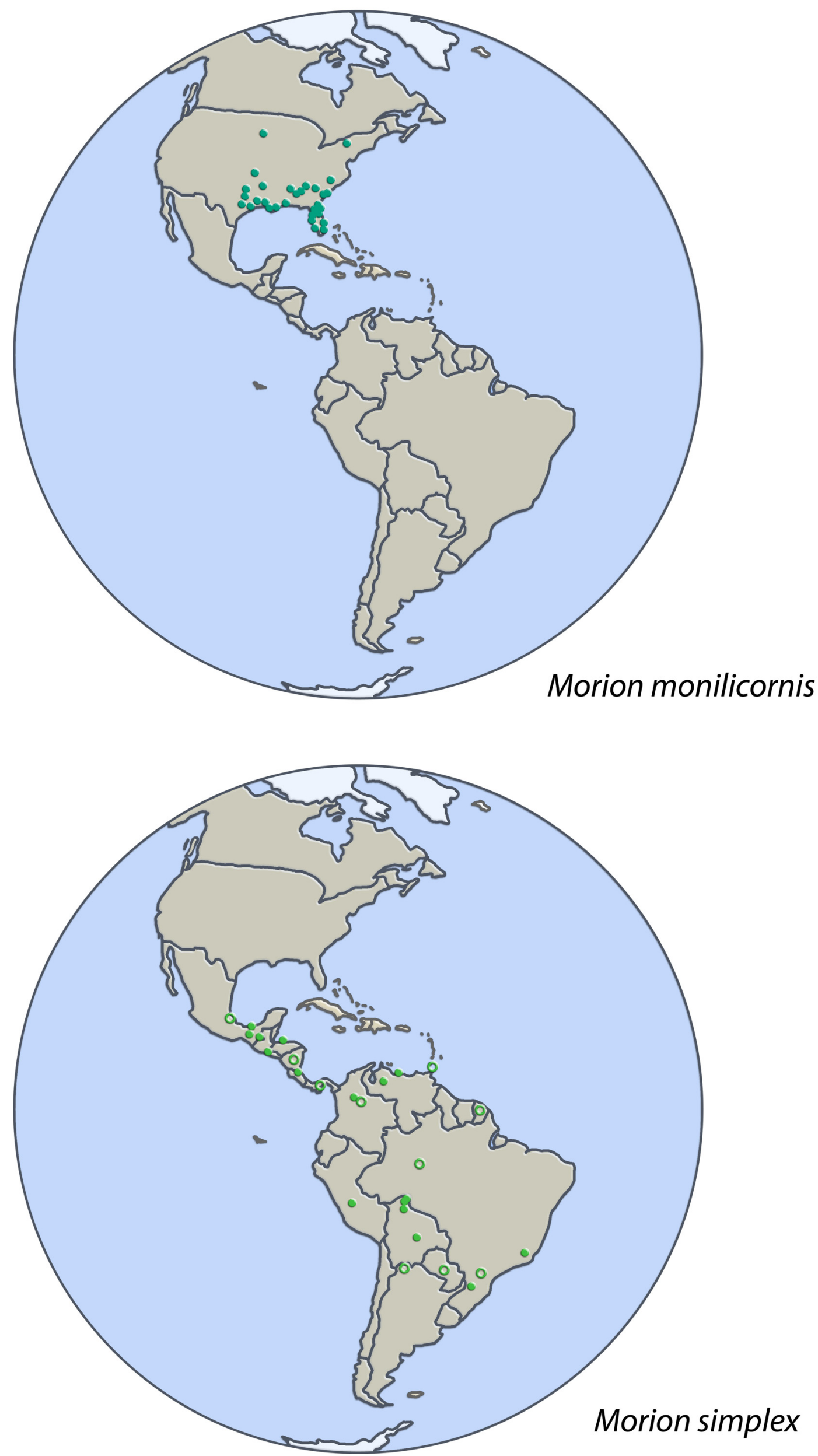

Prancha 57: Mapas com a distribuição geográfica das espécies Morion monilicornis e Morion simplex, baseada em dados da literatura. Os pontos abertos representam localidades não exatas. 

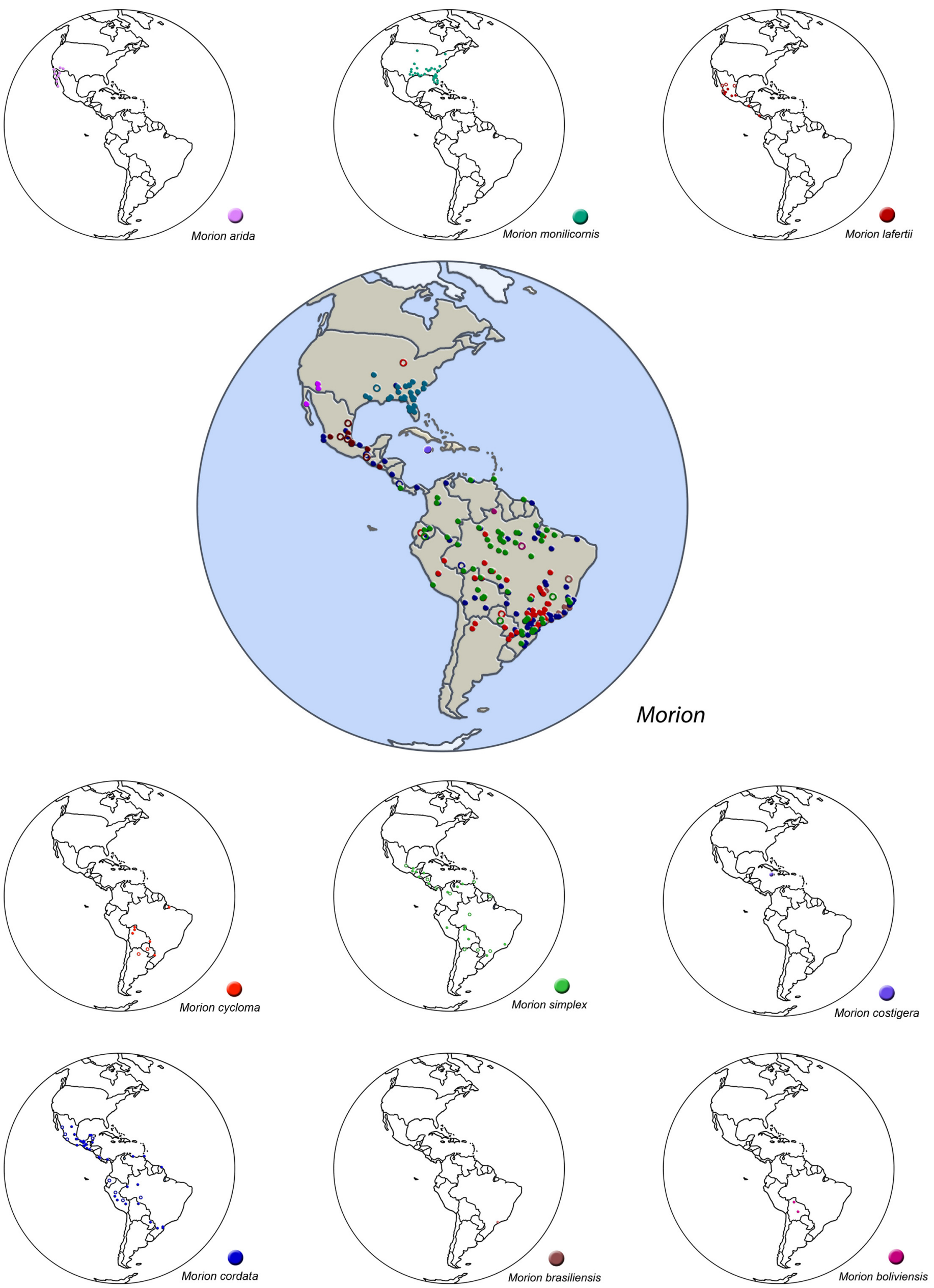

Prancha 58: Distribuição geográfica das espécies de Morion das Américas. Cada mapa pequeno representa a distribuição de uma espécie. Os pontos referem-se às localidades obtidas na literatura; os pontos abertos às localidades não exatas. O mapa grande central une as informações dos mapas menores. 

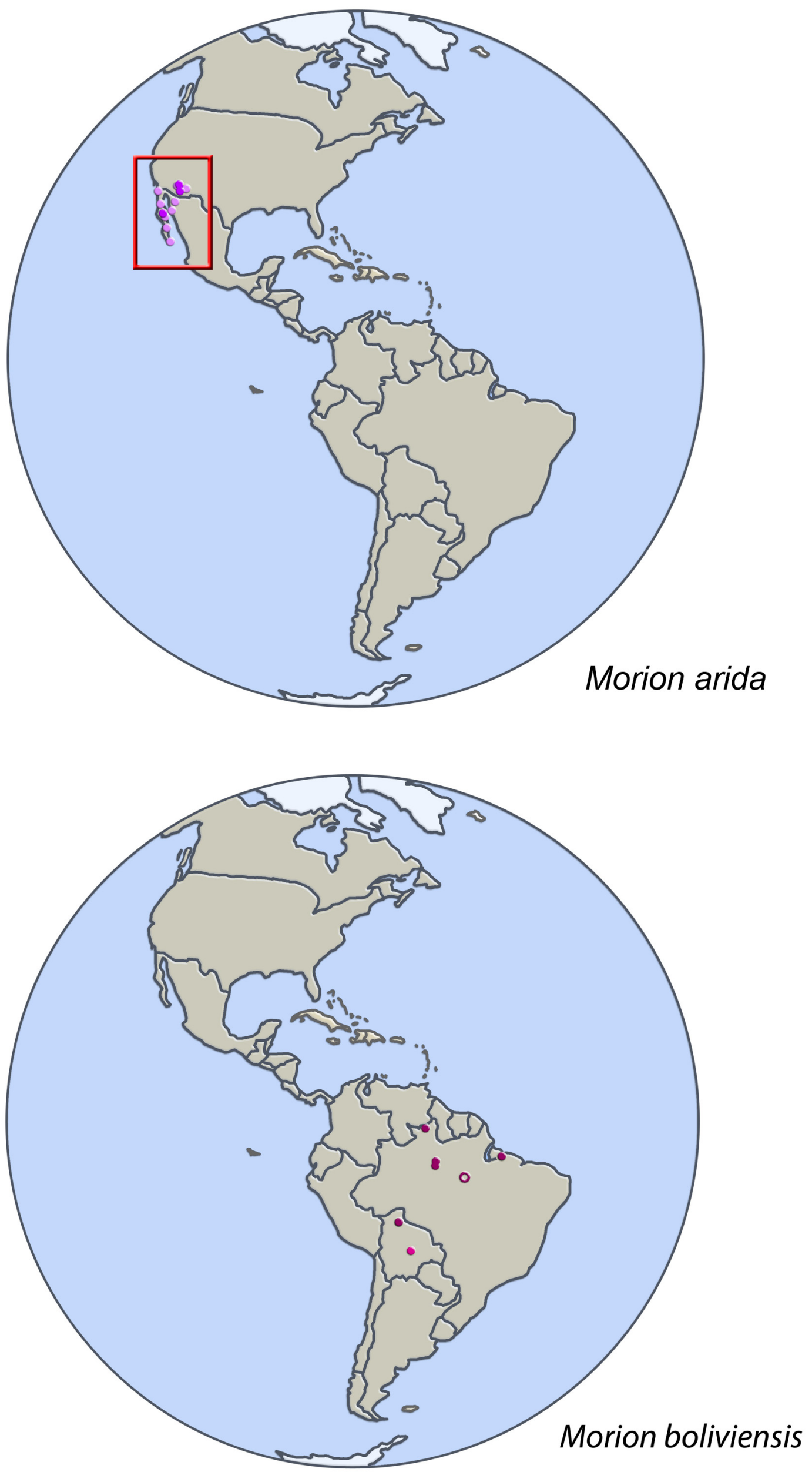

Prancha 59: Mapas com a distribuição geográfica das espécies Morion arida e Morion boliviensis. Os pontos claros se referem às localidades obtidas da literatura e os pontos escuros às localidades obtidas dos rótulos do material examinado. Os pontos abertos representam localidades não exatas. A moldura vermelha é apenas para facilitar a localização dos pontos. 

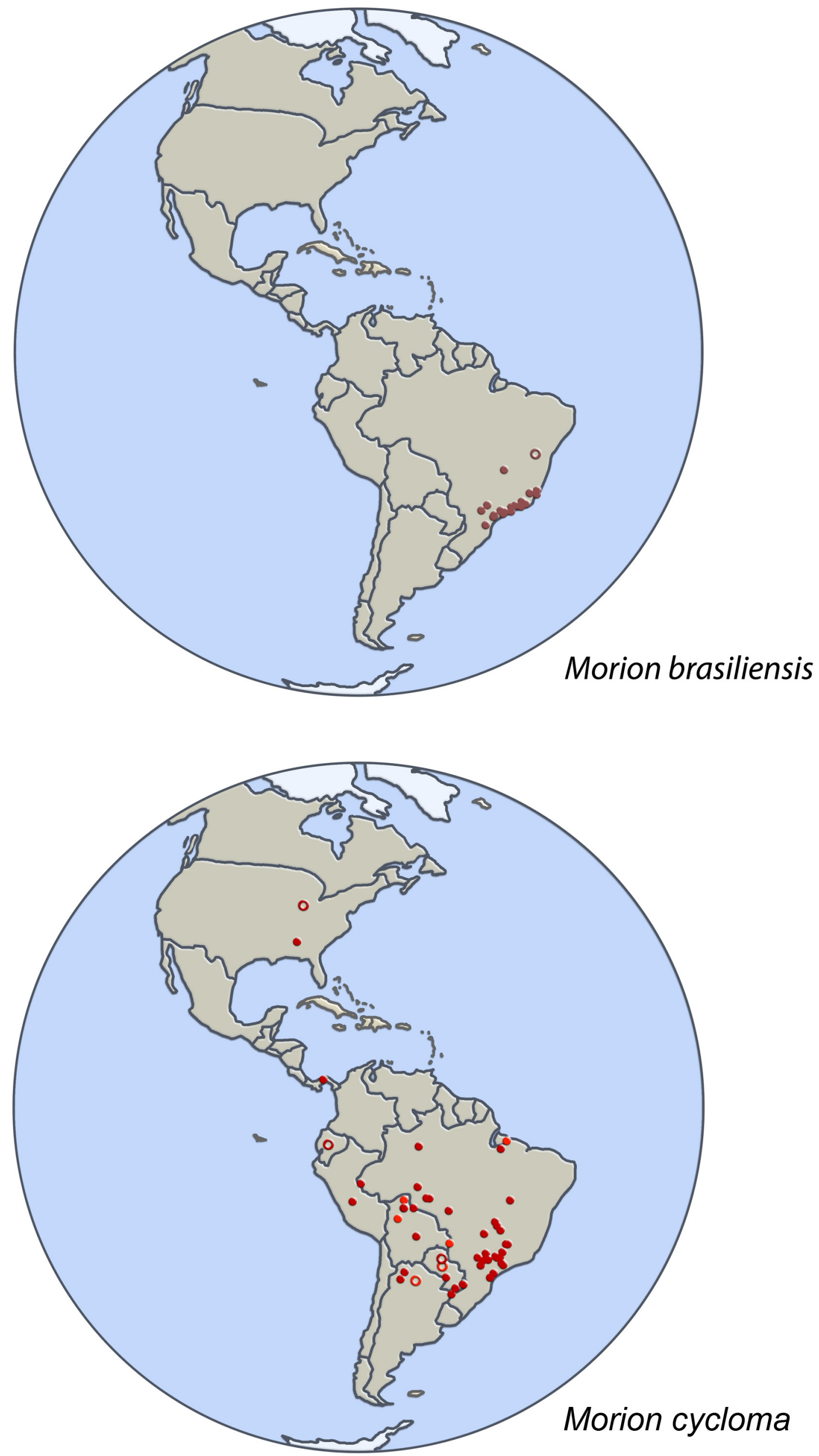

Prancha 60: Mapas com a distribuição geográfica das espécies Morion brasiliensis e Morion cycloma. Os pontos claros se referem às localidades obtidas da literatura e os pontos escuros às localidades obtidas dos rótulos do material examinado. Os pontos abertos representam localidades não exatas. 


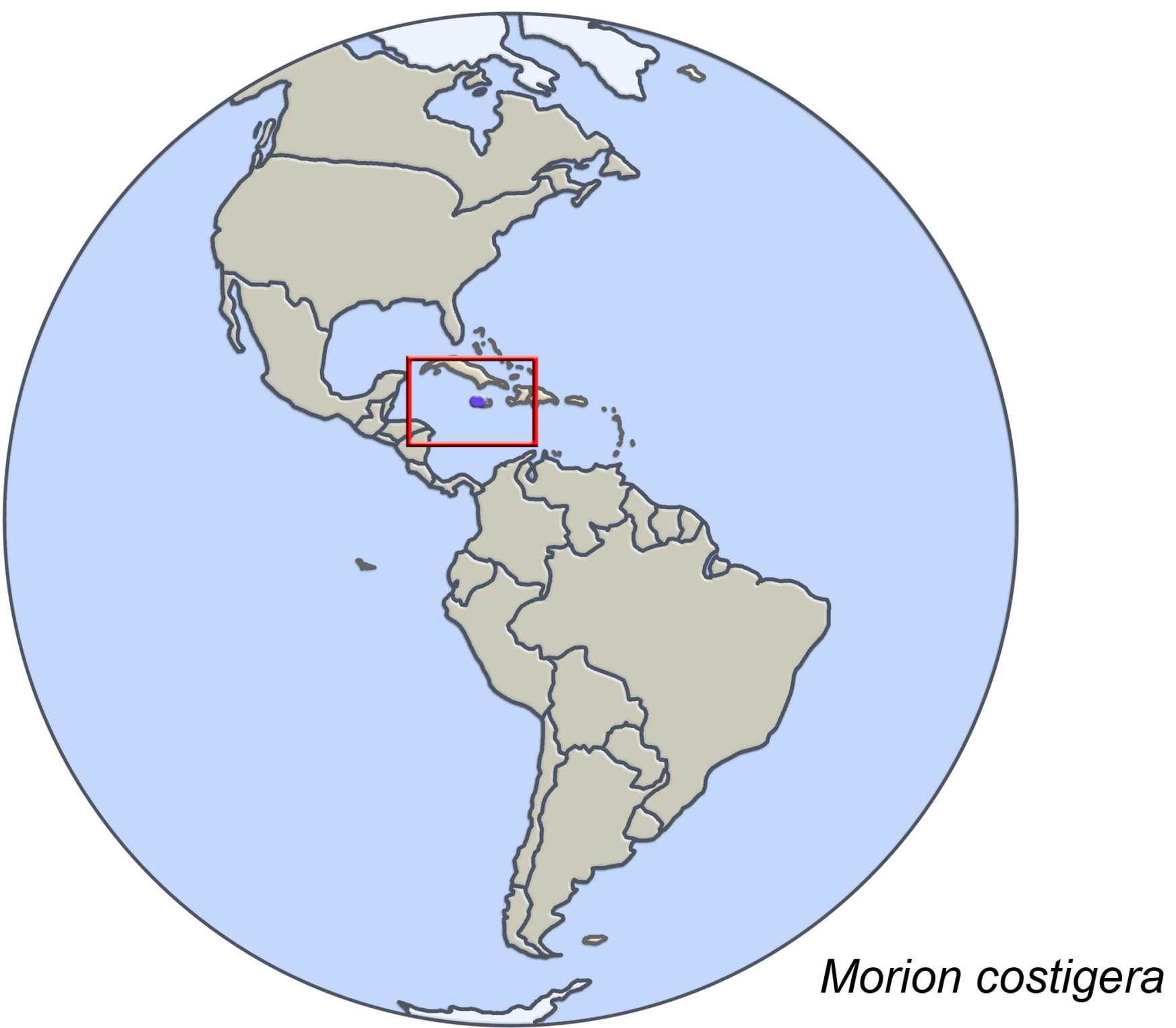

Prancha 61: Mapas com a distribuição geográfica de Morion costigera. Os pontos se referem às localidades obtidas da literatura. Nenhum material foi examinado no presente trabalho. A moldura vermelha é apenas para facilitar a localização dos pontos. 

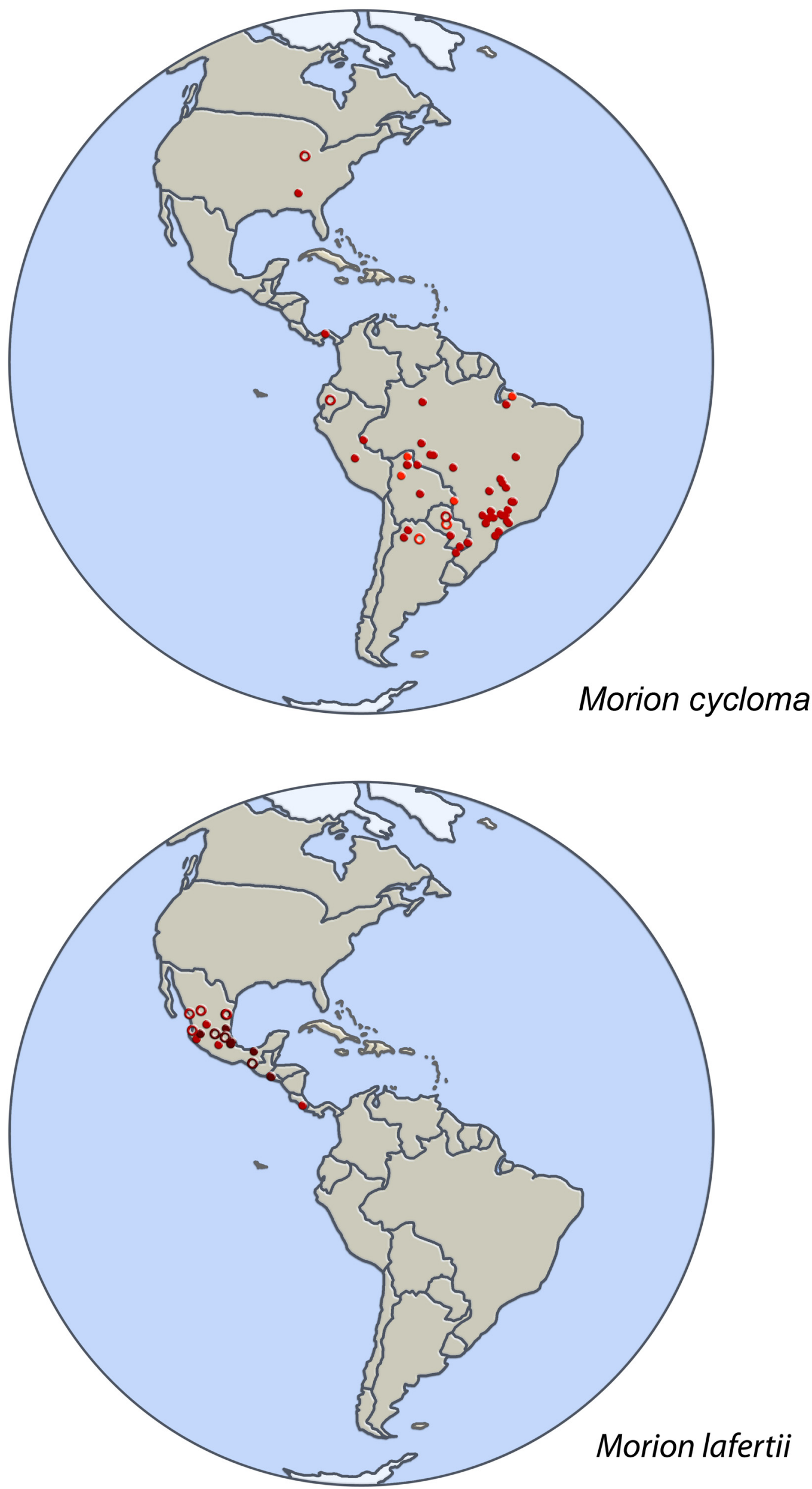

Prancha 62: Mapas com a distribuição geográfica das espécies Morion cycloma e Morion lafertii. Os pontos claros se referem às localidades obtidas da literatura e os pontos escuros às localidades obtidas dos rótulos do material examinado. Os pontos abertos representam localidades não exatas. 

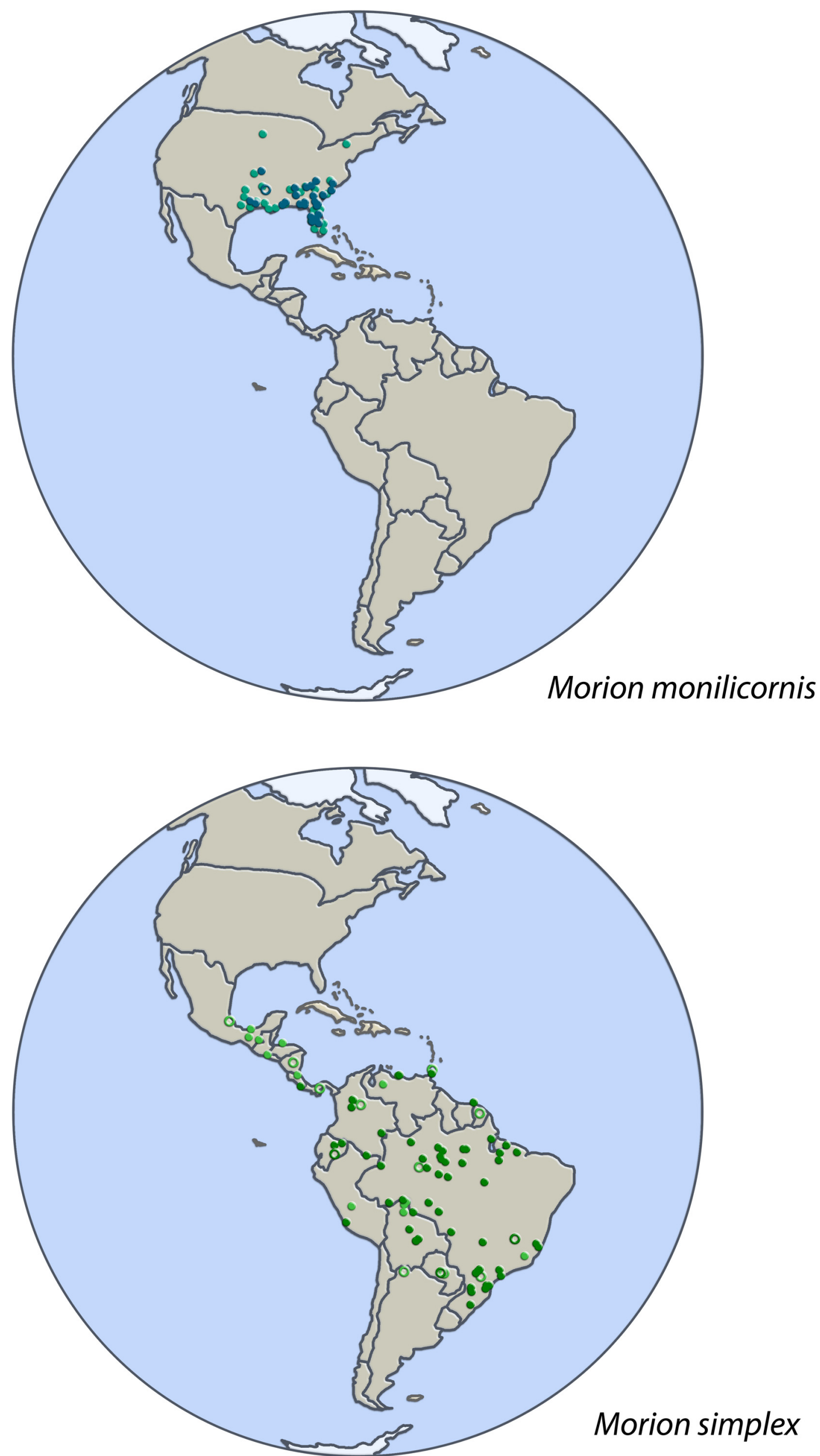

Prancha 63: Mapas com a distribuição geográfica das espécies Morion monilicornis e Morion simplex. Os pontos claros se referem às localidades obtidas da literatura e os pontos escuros às localidades obtidas dos rótulos do material examinado. Os pontos abertos representam localidades não exatas. 

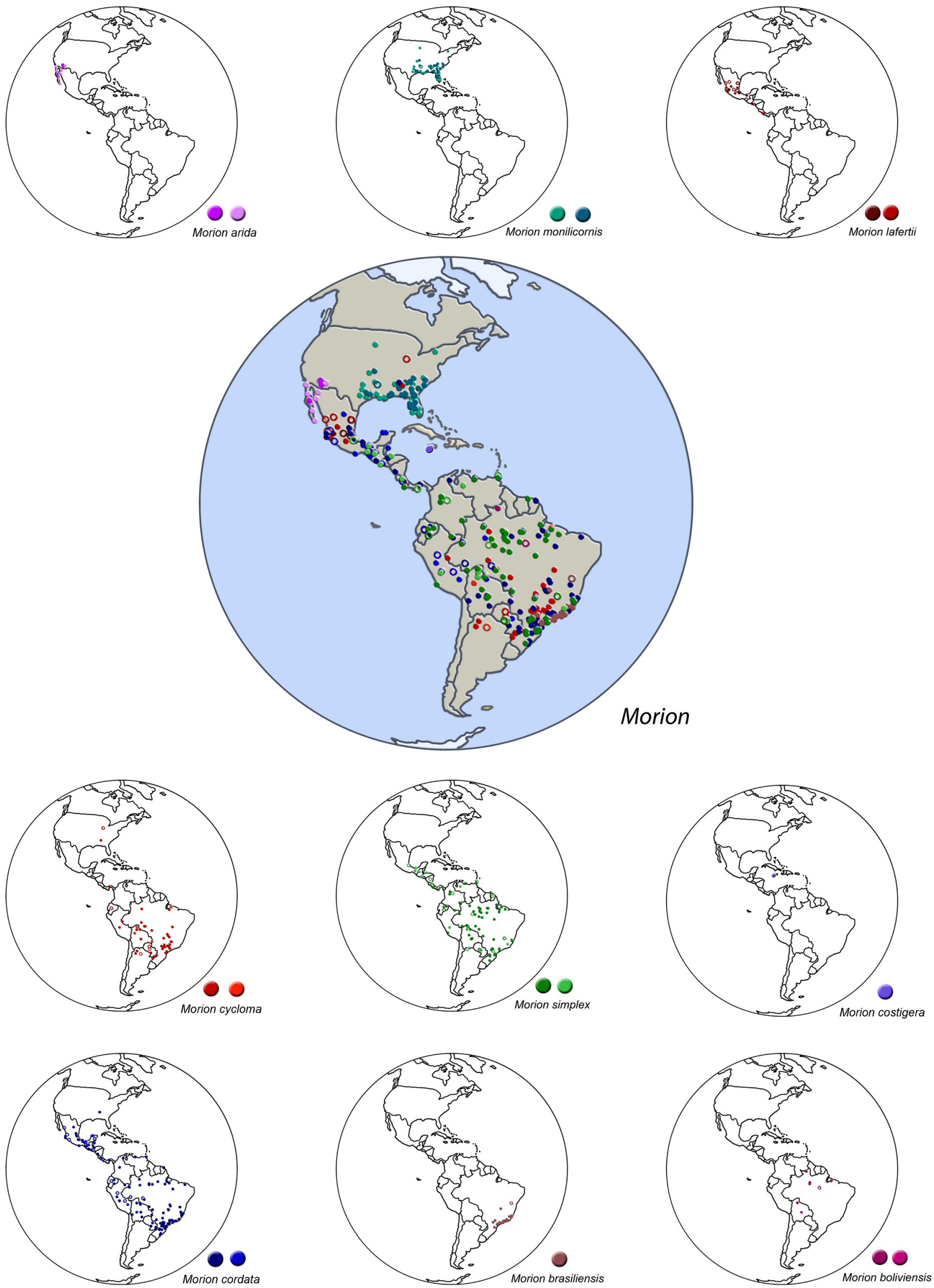

Prancha 64: Distribuição geográfica das espécies de Morion das Américas. Cada mapa pequeno representa a distribuição de uma espécie; os pontos claros referem-se às localidades obtidas na literatura; os pontos mais escuros às localidades obtidas das etiquetas do material examinado; os pontos abertos às localidades não exatas. O mapa grande central une as informações dos mapas menores. 

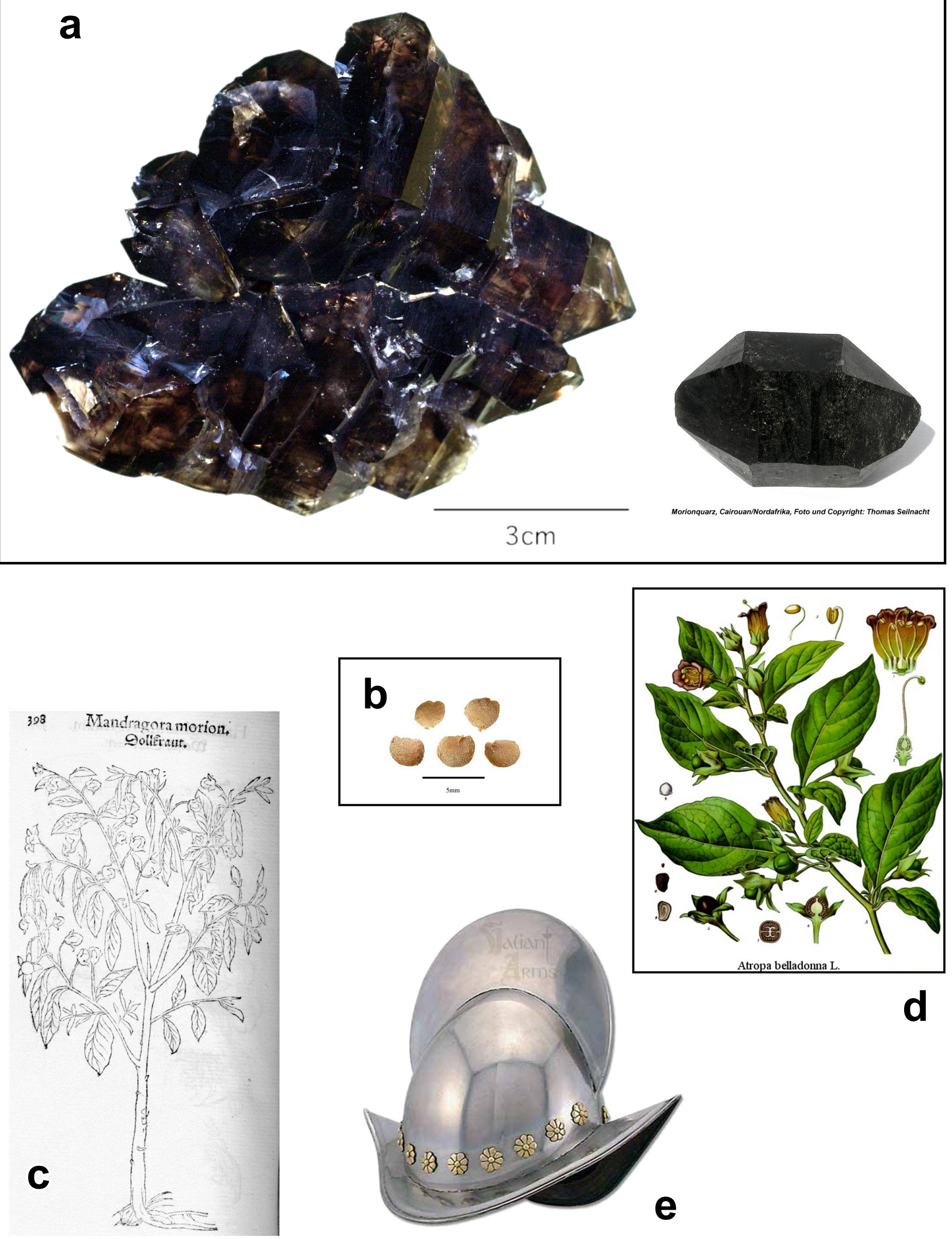

Prancha 65: Diferentes significados para "morion". a. Quartzo morion; b. sementes de Mandragora $s p . ;$ c. Mandragora morion; d. Beladona (nightshade); e. capacete morion (morrião). 